San Jose State University

SJSU ScholarWorks

Master's Theses

Master's Theses and Graduate Research

Fall 2009

\title{
Urban creek restoration, Adobe Creek, Santa Clara County, California.
}

Chris D. Pilson

San Jose State University

Follow this and additional works at: https://scholarworks.sjsu.edu/etd_theses

\section{Recommended Citation}

Pilson, Chris D., "Urban creek restoration, Adobe Creek, Santa Clara County, California." (2009). Master's Theses. 3995.

DOI: https://doi.org/10.31979/etd.mbv7-fnfb

https://scholarworks.sjsu.edu/etd_theses/3995

This Thesis is brought to you for free and open access by the Master's Theses and Graduate Research at SJSU ScholarWorks. It has been accepted for inclusion in Master's Theses by an authorized administrator of SJSU ScholarWorks. For more information, please contact scholarworks@sjsu.edu. 


\section{NOTE TO USERS}

This reproduction is the best copy available. 



\title{
URBAN CREEK RESTORATION, ADOBE CREEK, SANTA CLARA COUNTY, CALIFORNIA
}

\author{
A Thesis \\ Presented to \\ The Faculty of the Department of Geology \\ San José State University \\ In Partial Fulfillment \\ of the Requirements for the Degree \\ Master of Science
}

by

Chris D. Pilson

December 2009 
UMI Number: 1484330

All rights reserved

INFORMATION TO ALL USERS

The quality of this reproduction is dependent upon the quality of the copy submitted.

In the unlikely event that the author did not send a complete manuscript and there are missing pages, these will be noted. Also, if material had to be removed, a note will indicate the deletion.

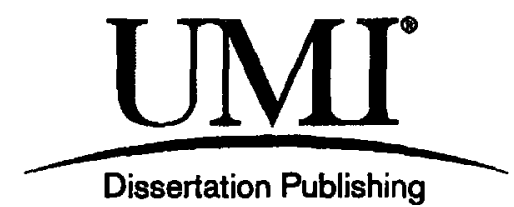

UMI 1484330

Copyright 2010 by ProQuest LLC.

All rights reserved. This edition of the work is protected against unauthorized copying under Title 17, United States Code.

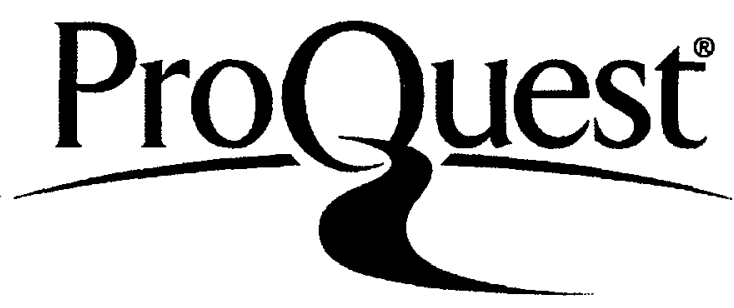

ProQuest LLC

789 East Eisenhower Parkway

P.O. Box 1346

Ann Arbor, Ml 48106-1346 
(C) 2009

Chris D. Pilson

ALL RIGHTS RESERVED 


\section{SAN JOSÉ STATE UNIVERSITY}

The Undersigned Thesis Committee Approves the Thesis Titled

\section{URBAN CREEK RESTORATION, ADOBE CREEK, SANTA CLARA COUNTY, CALIFORNIA}

by

Chris D. Pilson
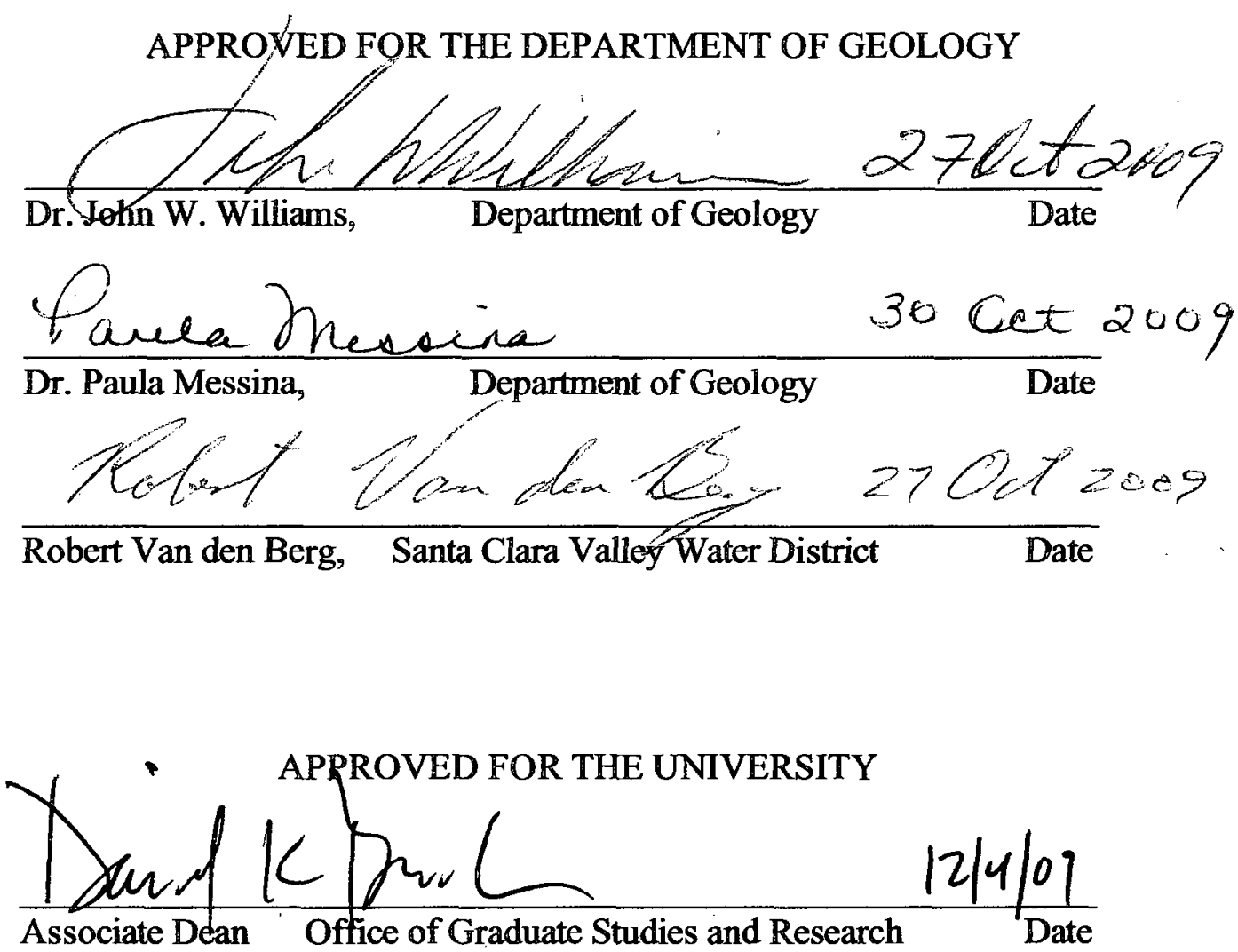


\section{ABSTRACT \\ URBAN CREEK RESTORATION, ADOBE CREEK, SANTA CLARA COUNTY, CALIFORNIA}

by Chris D. Pilson

Increased urban development has encroached upon and impacted Adobe Creek by constricting the route and volume of flow to predetermined corridors, often irrespective of the original creek morphology. The headwaters geology and human influences have contributed to the creek's disequilibrium. Channelization and instream modifications have segmented the creek system limiting the transfer of changes through the system. Located east of the San Andreas fault (SAF) in the Franciscan Complex, Adobe Creek flows from the eastern foothills of the Santa Cruz Mountains and empties into the San Francisco Bay.

A geomorphic creek design was developed for the upper $335 \mathrm{~m}(1100 \mathrm{ft})$ of Reach

5. Upper Reach 5 extends from West Edith Avenue to downstream of the confluence with the Robleda Creek storm drain. This reach and the park upstream are prone to flooding during winter months. Upper Reach 5 is characterized by failing bank protection structures and a discontinuous artificially hardened bed. These features contributed to reduced flow capacity and increased the potential for property loss. The solution was based on a geomorphic assessment and survey from the upper watershed in Hidden Villa downstream to Foothill Expressway in Los Altos. Stable geomorphic characteristics for Adobe Creek include an entrenchment ratio greater than 2.4 and a stream gradient of 0.75 . 


\section{ACKNOWLEDGEMENTS}

An enormous debt of gratitude is owed to Dr. Williams of San José State University, thank you for your patience, unyielding support and for reigning in my tangential research. Thank you. A posthumous thank you to Seena Hoose, without whose guidance I might never have found the opportunity on Adobe Creek and at the District. Thanks to everyone in the former Stream Water Quality Unit; especially Rob Van den Berg, Dipankar Sen and Brett Calhoun. Thanks to everyone else at the District who has helped me track down information and for letting me tag along. A huge thanks goes to my family for their patience, understanding and unwavering belief in my success. 


\section{TABLE OF CONTENTS}

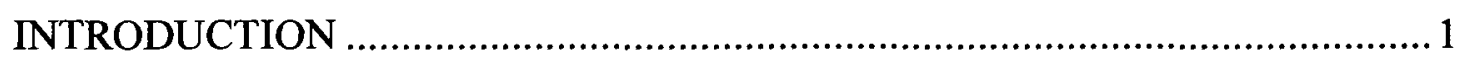

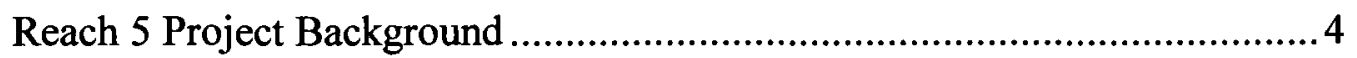

Scope of Research Project....................................................................... 10

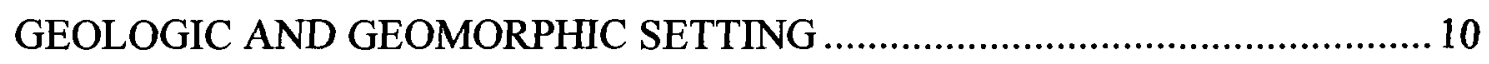

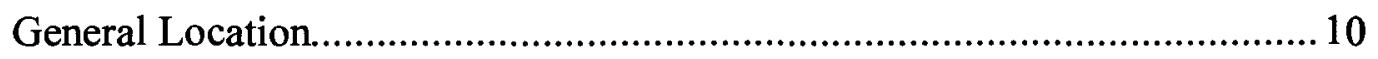

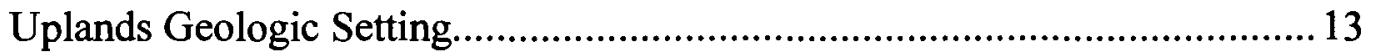

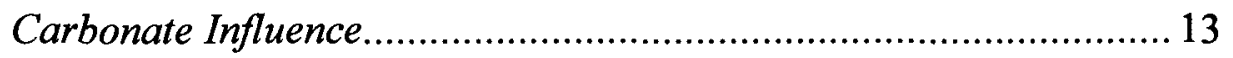

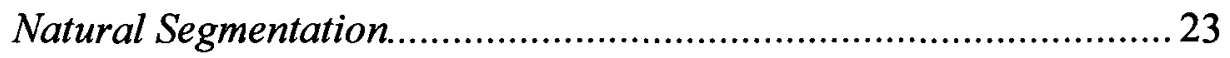

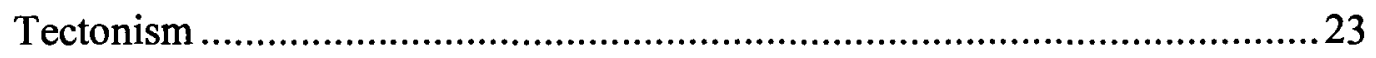

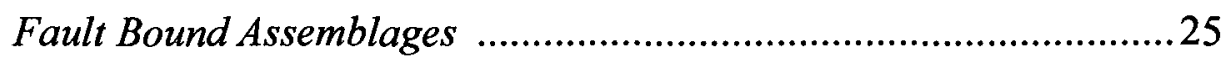

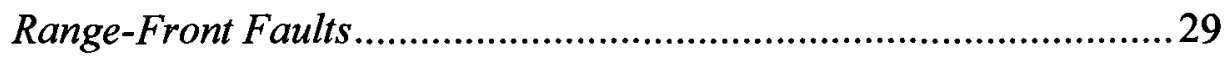

Valley Fill Materials and Subsurface Geology............................................... 34

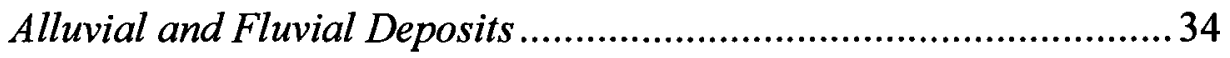

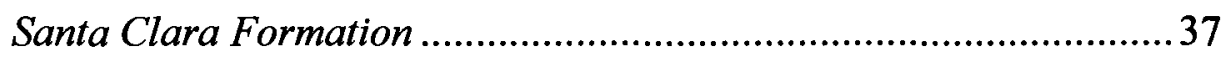

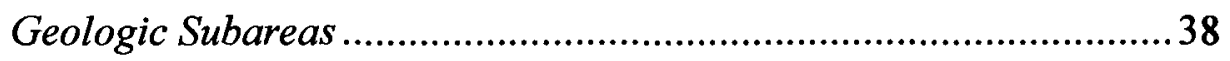

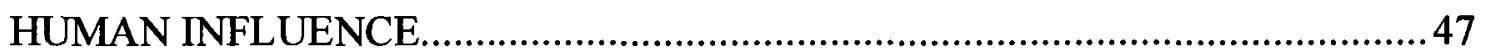

A Creek by Many Names ........................................................................ 47

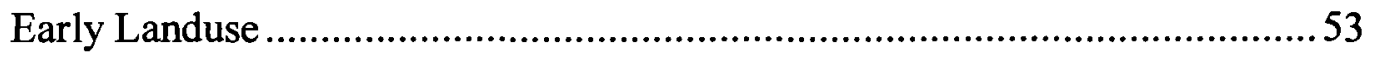

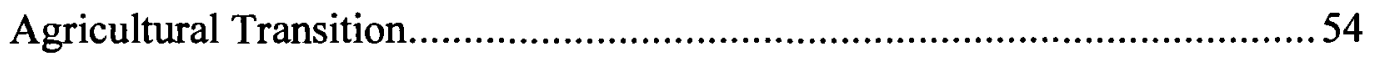

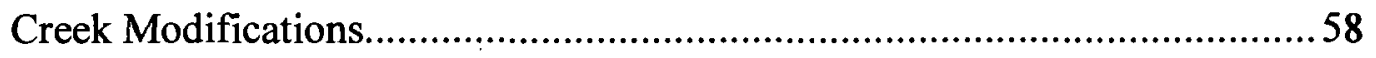

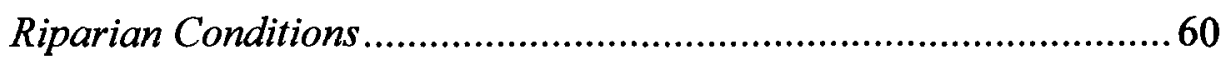


Segmentation

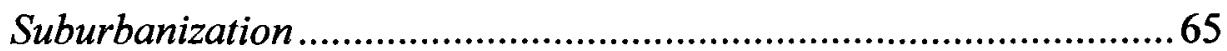

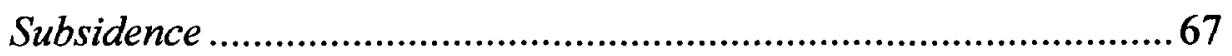

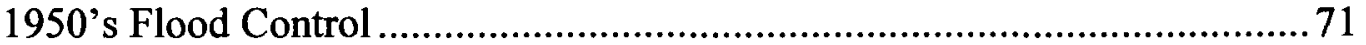

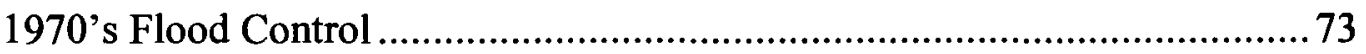

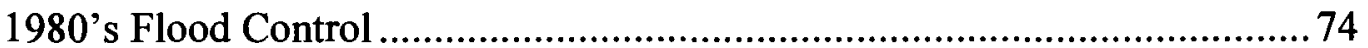

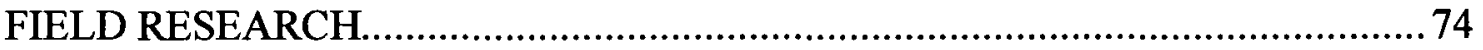

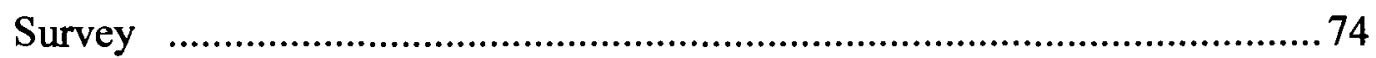

Longitudinal Profile .......................................................................79

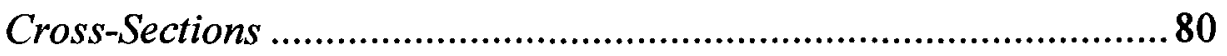

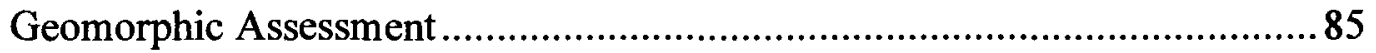

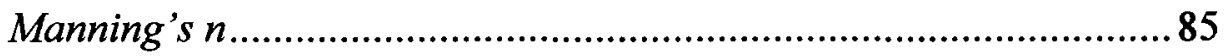

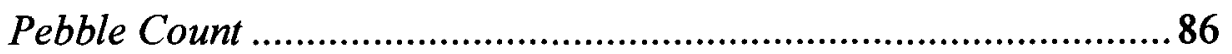

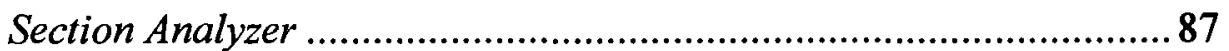

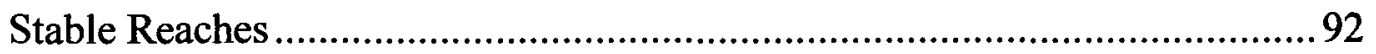

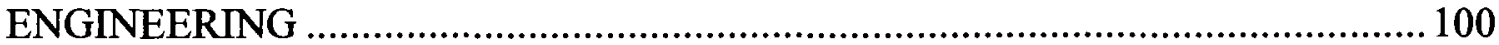

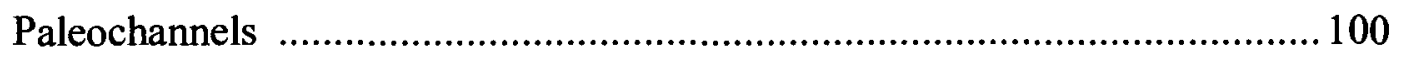

Transportation Corridor Modifications ......................................................... 103

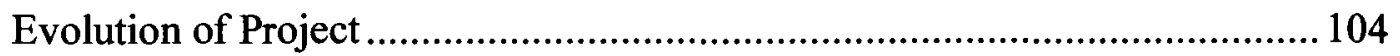

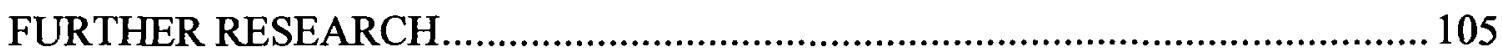

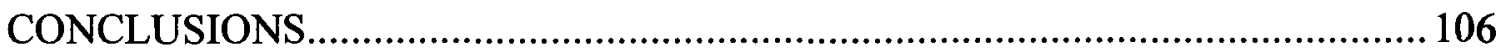

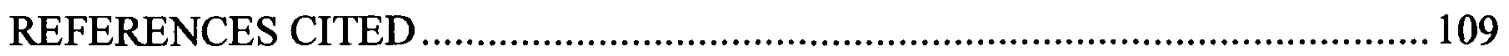




\section{LIST OF FIGURES}

Figure

1. General Location of Adobe Creek .......................................................... 2

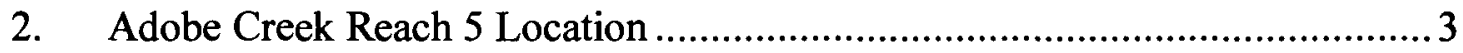

3. Historic Flooding in Adobe Creek Reach 5.............................................. 5

4. Aerial Photograph of Adobe Creek Upstream of Reach 5, 1956...................6

5. Adobe Creek Flooding Edith Park, 1952 ................................................ 7

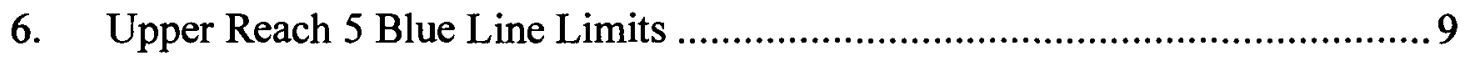

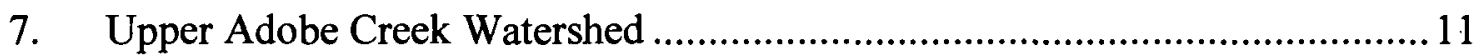

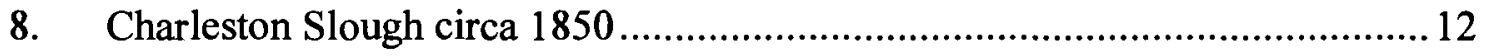

9. Average Annual Rainfall Dahl Ranch Rain Gauge....................................... 14

10. Average Monthly Rainfall at Dahl Ranch Gauge ........................................15

11. Carbonate Build-up in Previous Century's Water Supply Pipe........................ 17

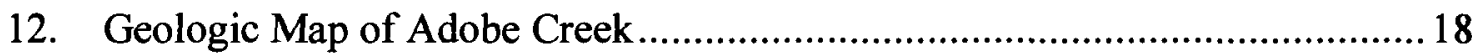

13. Cemented Forest Debris …...................................................................... 19

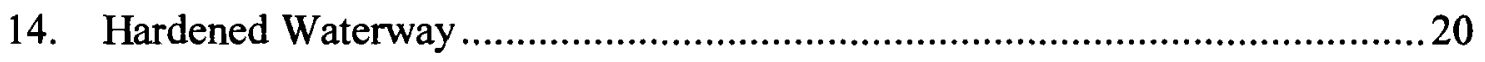

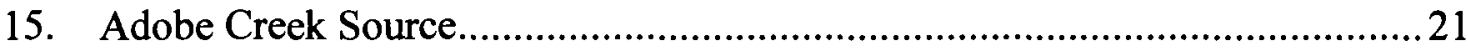

16. Geographic Features of the Santa Clara Valley .............................................24

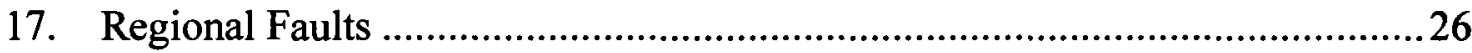

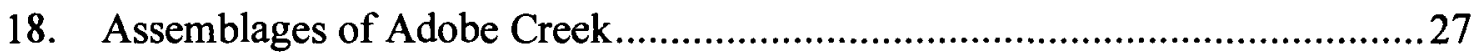

19. Reverse Range-Front Faults, 1975 ............................................................. 30

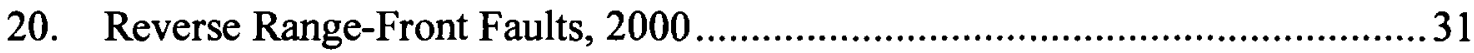




\section{LIST OF FIGURES (CON'T)}

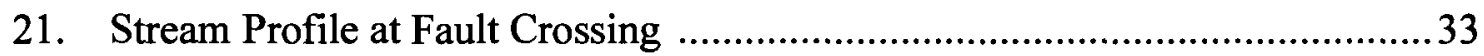

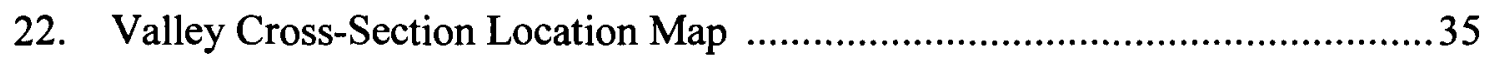

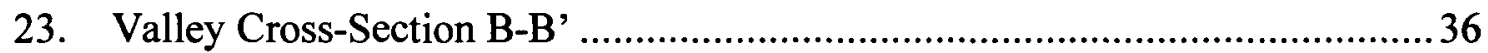

24. Confined Aquifer and Surface Recharge Zones, Santa Clara Valley ...............39

25. Schematic Cross-Section of the Santa Clara Valley ......................................40

26. Hydrogeologic Subareas of Western Santa Clara County................................42

27. Location of Van Buren Well No. 2 and Shoup Park ......................................43

28. Downstream-most Extent of the Natural Unmodified Channel.........................45

29. Trapezoidal Channel Downstream of El Camino Real .................................46

30. Lower Adobe Creek Channelized Flatlands .................................................48

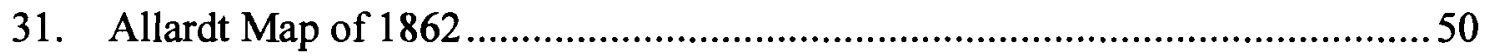

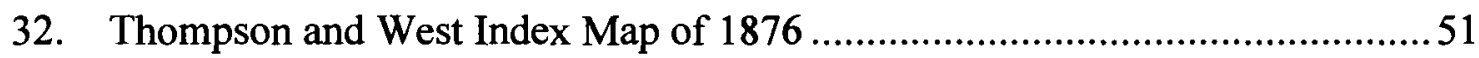

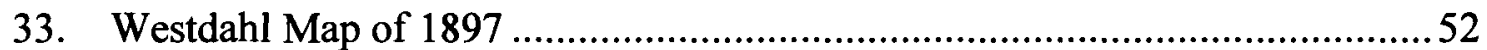

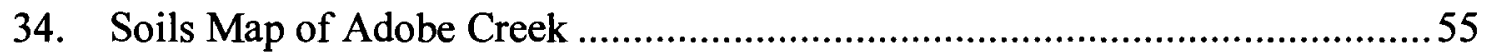

35. Earthen Transition, Ephemeral Branches, Paleochannels and Sausals ............57

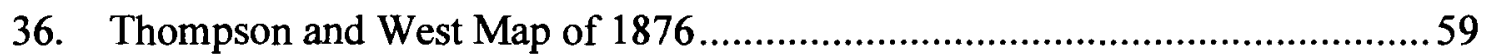

37. 1899 Palo Alto 30-Minute Quadrangle ......................................................61

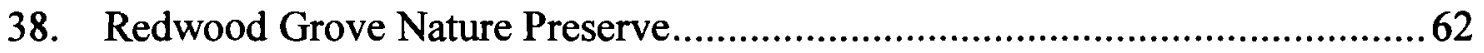

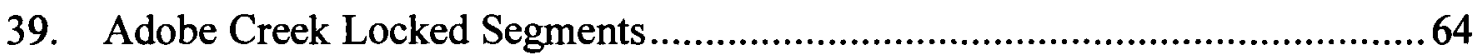

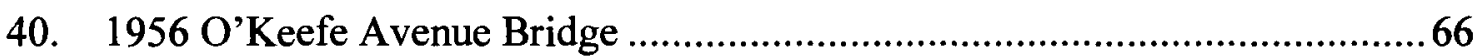

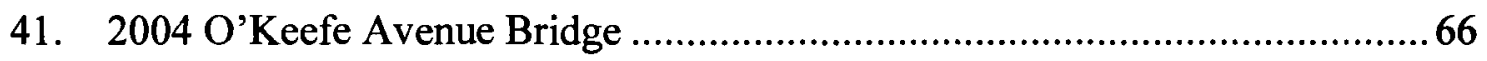




\section{LIST OF FIGURES (CON'T)}

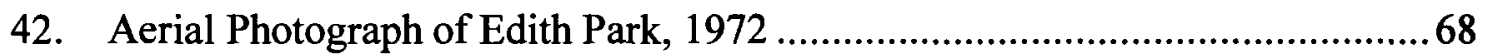

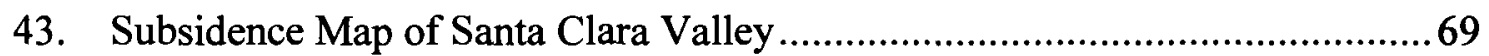

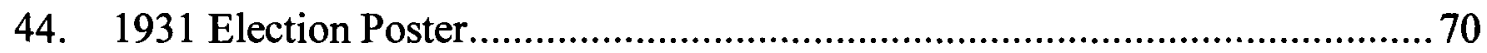

45. Depth to Groundwater, Population and Subsidence Graph ............................72

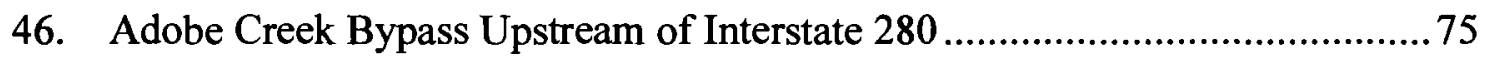

47. Typical Channelized Section through Foothill College …...............................76

48. Typical Bridge Crossing in Foothill College ................................................. 77

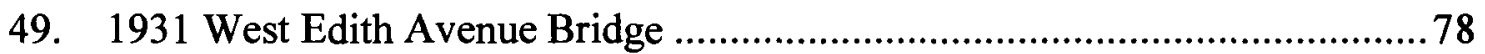

50. Cross-Section and Pebble Count Location Index Map ...................................81

51. Hidden Villa Cross-Section and Pebble Count Locations................................8 82

52. Lower Adobe Creek Cross-Section and Pebble Count Locations .....................83

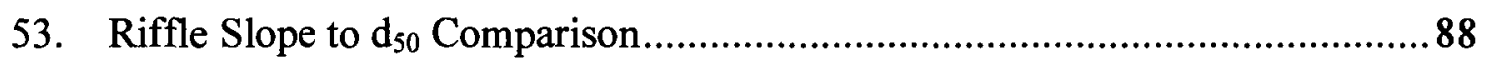

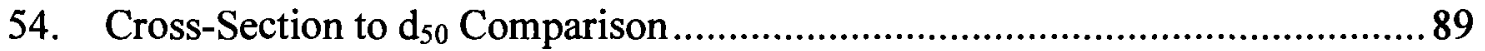

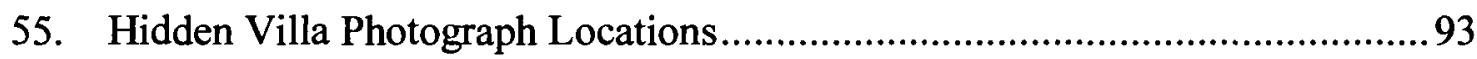

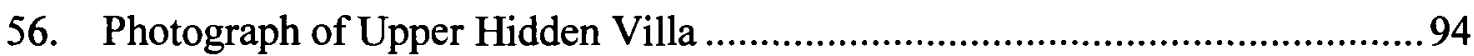

57. View Downstream, Upstream of West Branch Confluence ..............................96

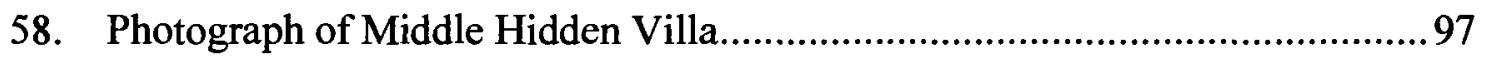

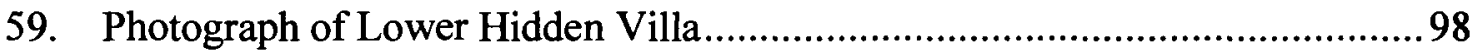

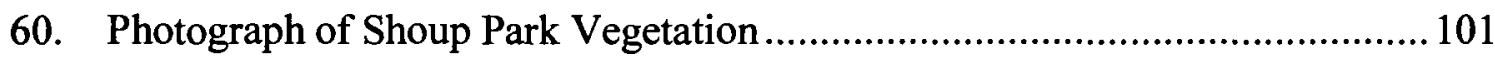




\section{LIST OF TABLES}

Table

1. Water Chemistry of Adobe Creek, Hardness.........................................22

2. Industry Change in San José, California .........................................56

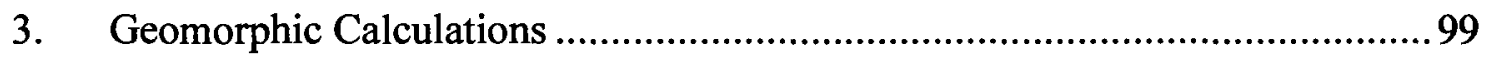

4. Alternative Designs Comparison ................................................. 102

\section{LIST OF APPENDICES}

Appendix

A. Longitudinal Profiles ............................................................................ 116

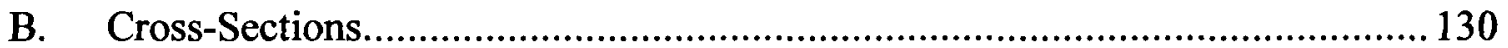

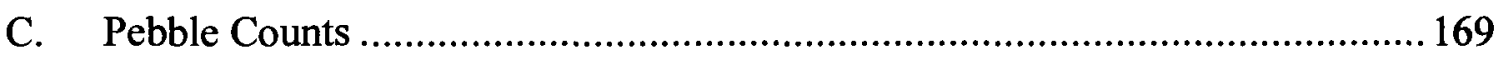




\section{INTRODUCTION}

The goal of this project was to support a design for a stable creek in the upper portion of Adobe Creek Reach 5. This reach was plagued by instream erosion, extensive failing bank protection structures and reduced flow capacity. The geomorphic design was based on data from field measurements of the physical properties of Adobe Creek. Creek reaches free of indicators of incision or aggradation and lateral migration were considered stable. These stretches of creek were used as reference reaches to be studied then emulated. The design was to provide flood protection, increase riparian habitat and decrease hardscape. Approximately 1.5 percent of the overall length of the creek was addressed by this project. See Figure 1 for the location of Adobe Creek within Santa Clara County and Figure 2 for a close-up of Upper Reach 5, which extends approximately $335 \mathrm{~m}(1100 \mathrm{ft})$ downstream of the West Edith Avenue Bridge.

Adobe Creek has a history of flooding from Reach 5 upstream through Edith Park. In a Los Altos History Show interview (Geschke, 1998) with Ruth Eleanor Cranston Fowle Cameron, a long-time resident of the Los Altos region, she described the creek behavior during the early $20^{\text {th }}$ century in the area of Reach 5 . Her family, the Cranstons, lived on a hill above the creek at the corner of Fremont and Campo Vista Lane. On Figure 2, the letter A marks the location of the house on the hill. As a young girl, she recalled that sometimes she and her family were marooned on their hill because they would "look down [at Adobe Creek] upon this lake of spreading brown water." Eleanor said the river ran all year round, sometimes as a raging torrent. Adobe Creek 


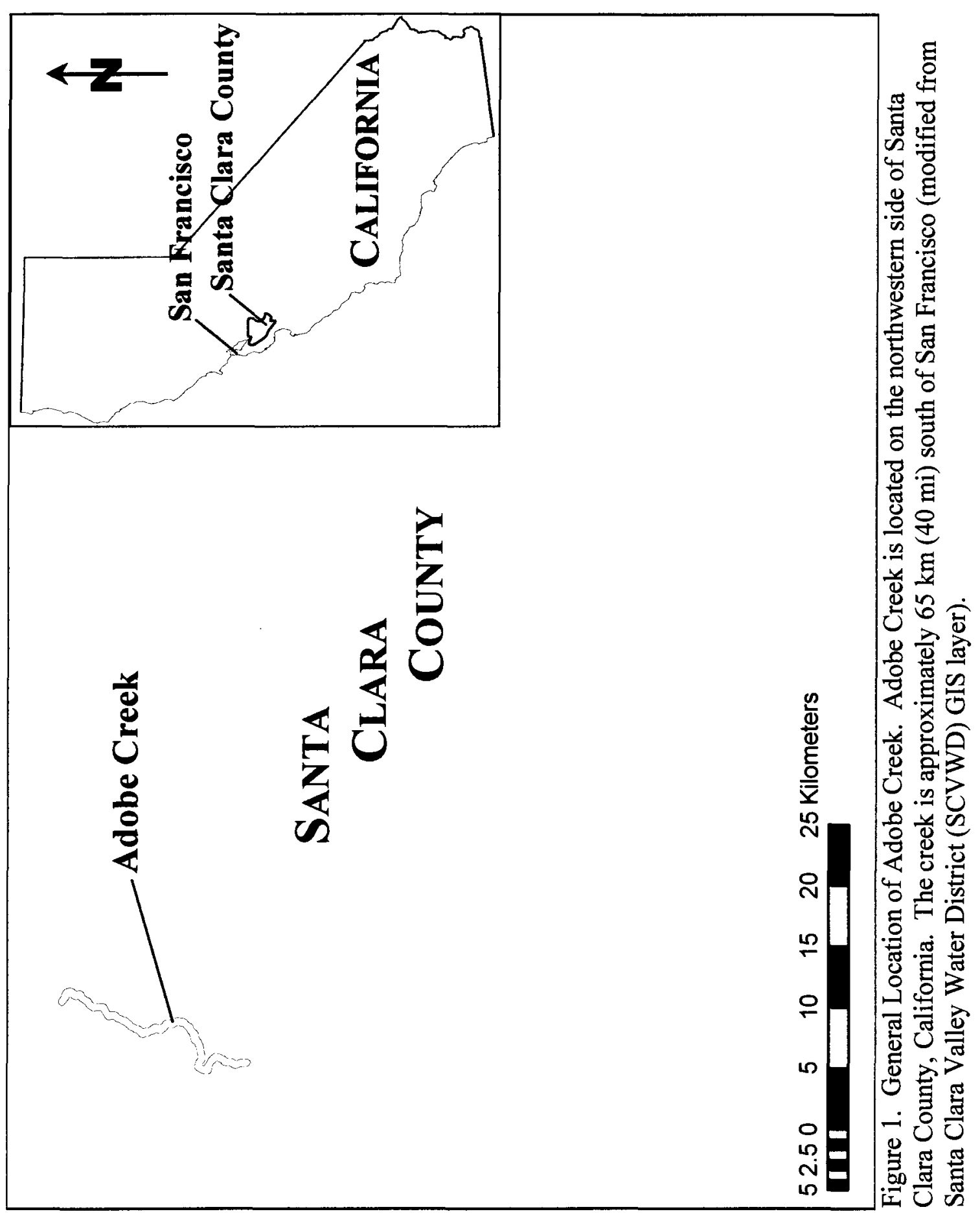




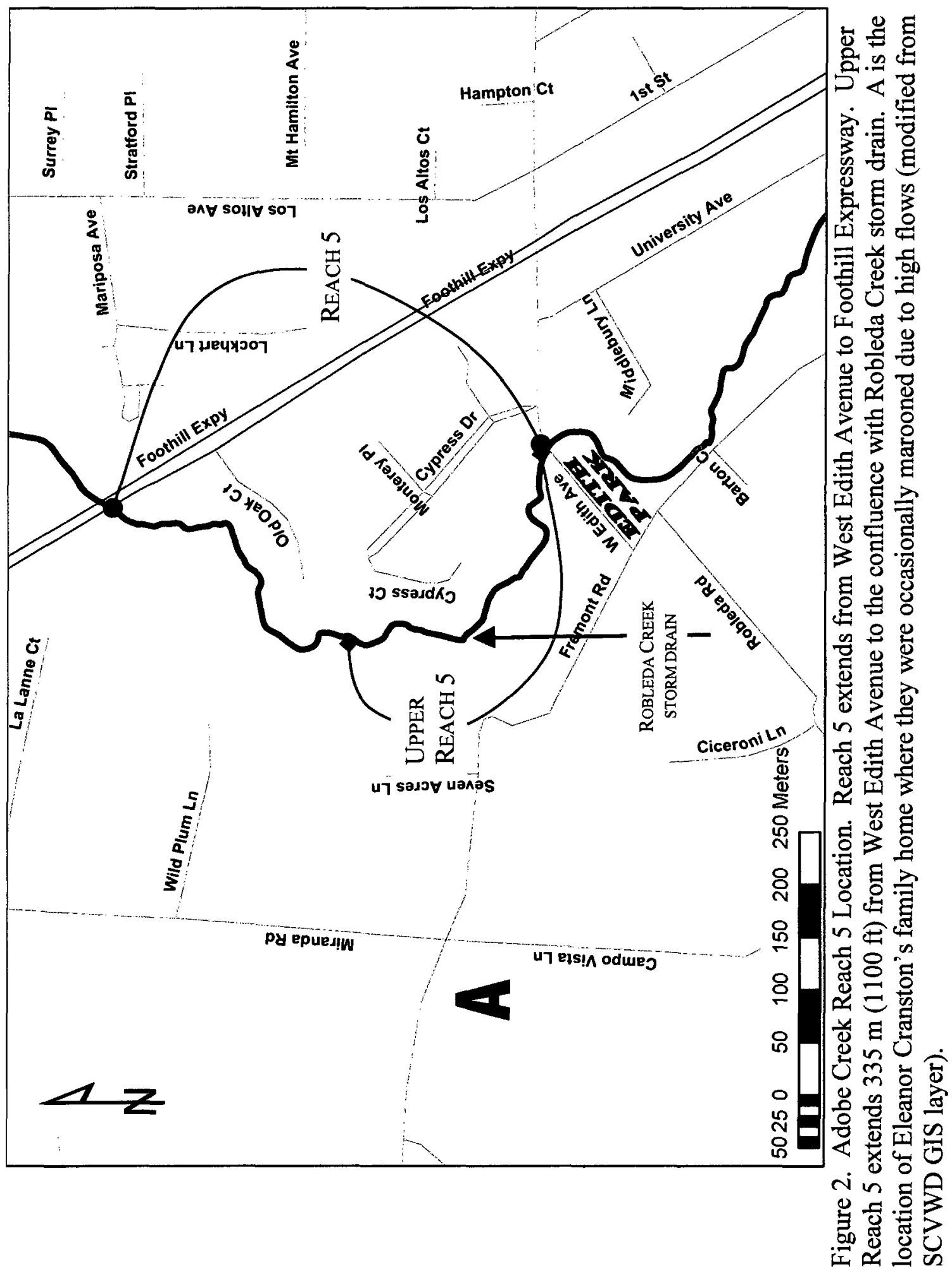


flowed year round until 1912 according to the information compiled by Don McDonald for the Los Altos History House Association. Figure 3 shows the extent of recent floods in the region of Reach 5. Figure 4 shows the high water marks of the Christmas Week Floods of 1955. On Figure 4, the perspective of Figure 5 is represented by the letter B. The view of this photograph is from Fremont Avenue looking east across present-day Edith Park.

\section{Reach 5 Project Background}

The initial effort to address Adobe Creek Upper Reach 5 began in 1999 when the Santa Clara Valley Water District (SCVWD; the "District") planned to install a redesigned section of creek that would contain the 100 -year flood event or the 1 percent flows. The 100-year event has a 1 percent chance of happening in any given year. The creek design for this capacity required a $27 \mathrm{~m}(90 \mathrm{ft})$ wide channel from top of bank to top of bank. The design included a $3 \mathrm{~m}$ (10 ft) wide, low-flow channel and a $3 \mathrm{~m}(10 \mathrm{ft})$ wide mid-bank bench to be vegetated and to count toward mitigation credit. Mitigation is the term used to describe the reparations made in a compensatory ratio based on the acreage of fresh water wetland or riparian habitat impacted by stream maintenance

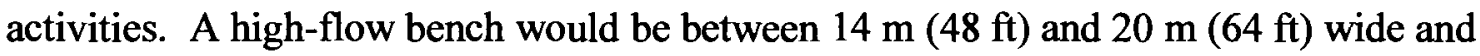
vegetated with low ground cover. The multi-benched approach would extend $213 \mathrm{~m}$ (700 $\mathrm{ft})$ downstream of West Edith Avenue. The next $61 \mathrm{~m}(200 \mathrm{ft})$ of channel were to be widened from the existing $3 \mathrm{~m}$ (10 ft) width to $6 \mathrm{~m}(20 \mathrm{ft})$ (SCVWD, 2007a). 


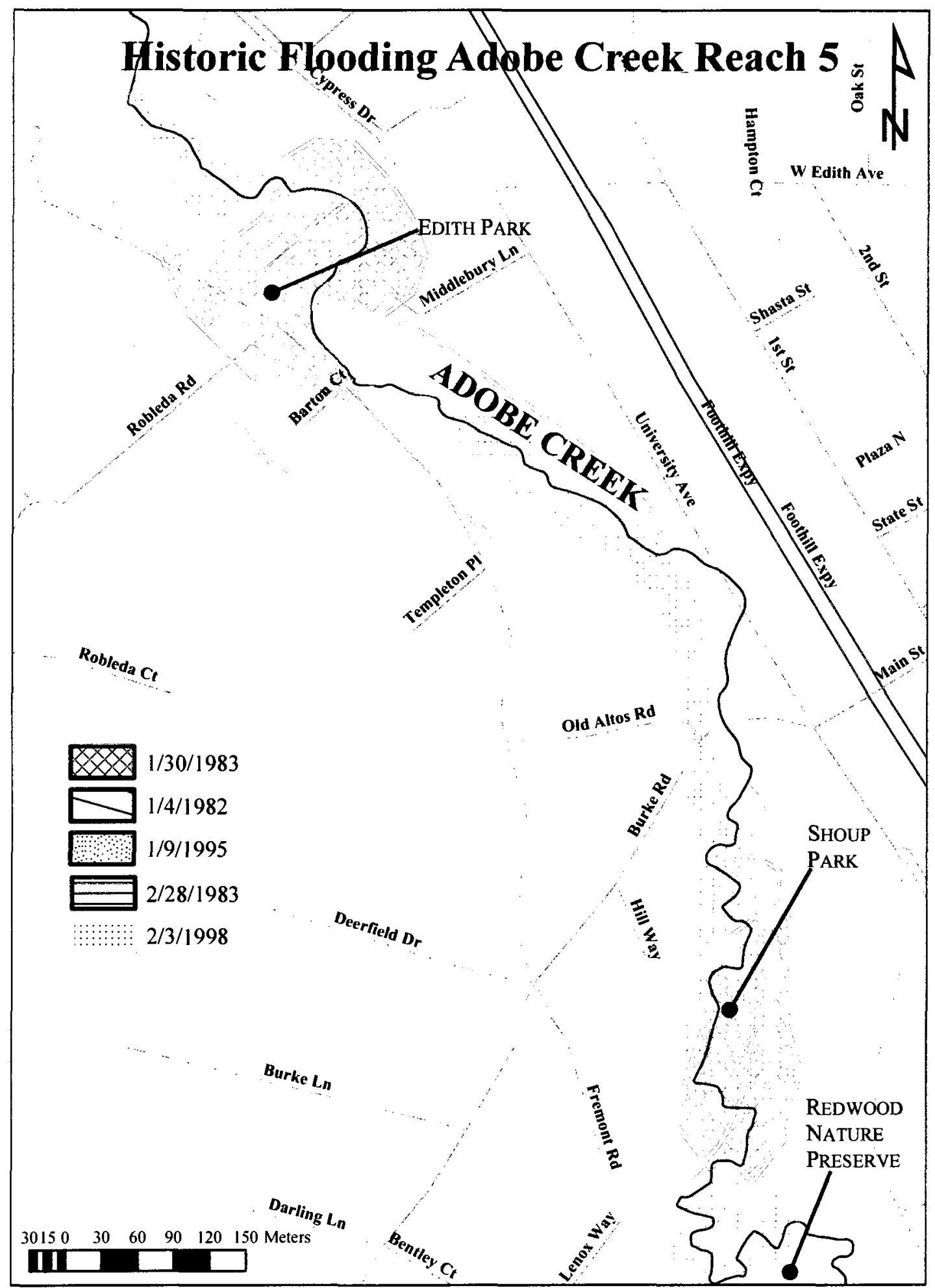

Figure 3. Historic Flooding in Adobe Creek Reach 5 (modified from SCVWD GIS layer). 


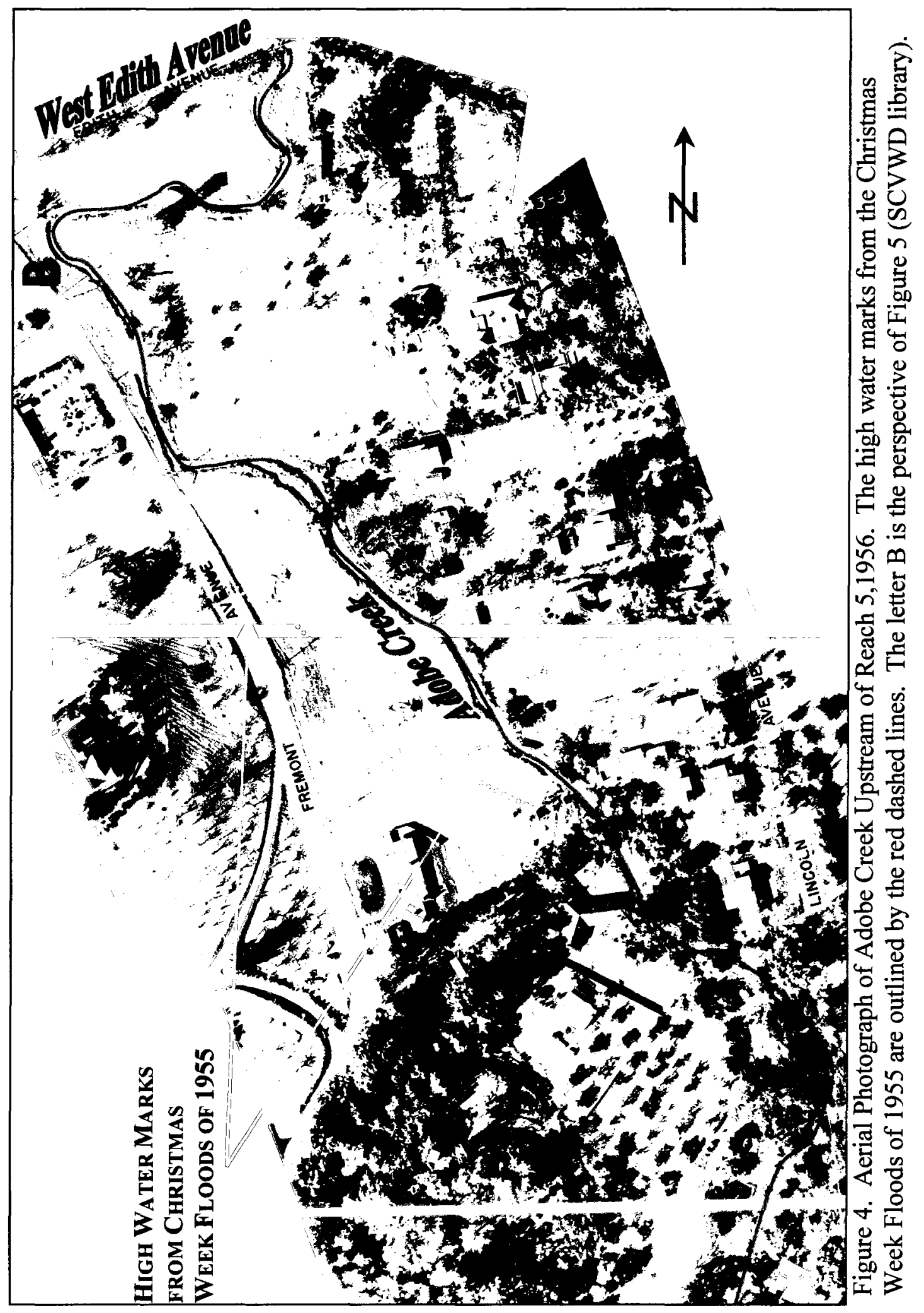




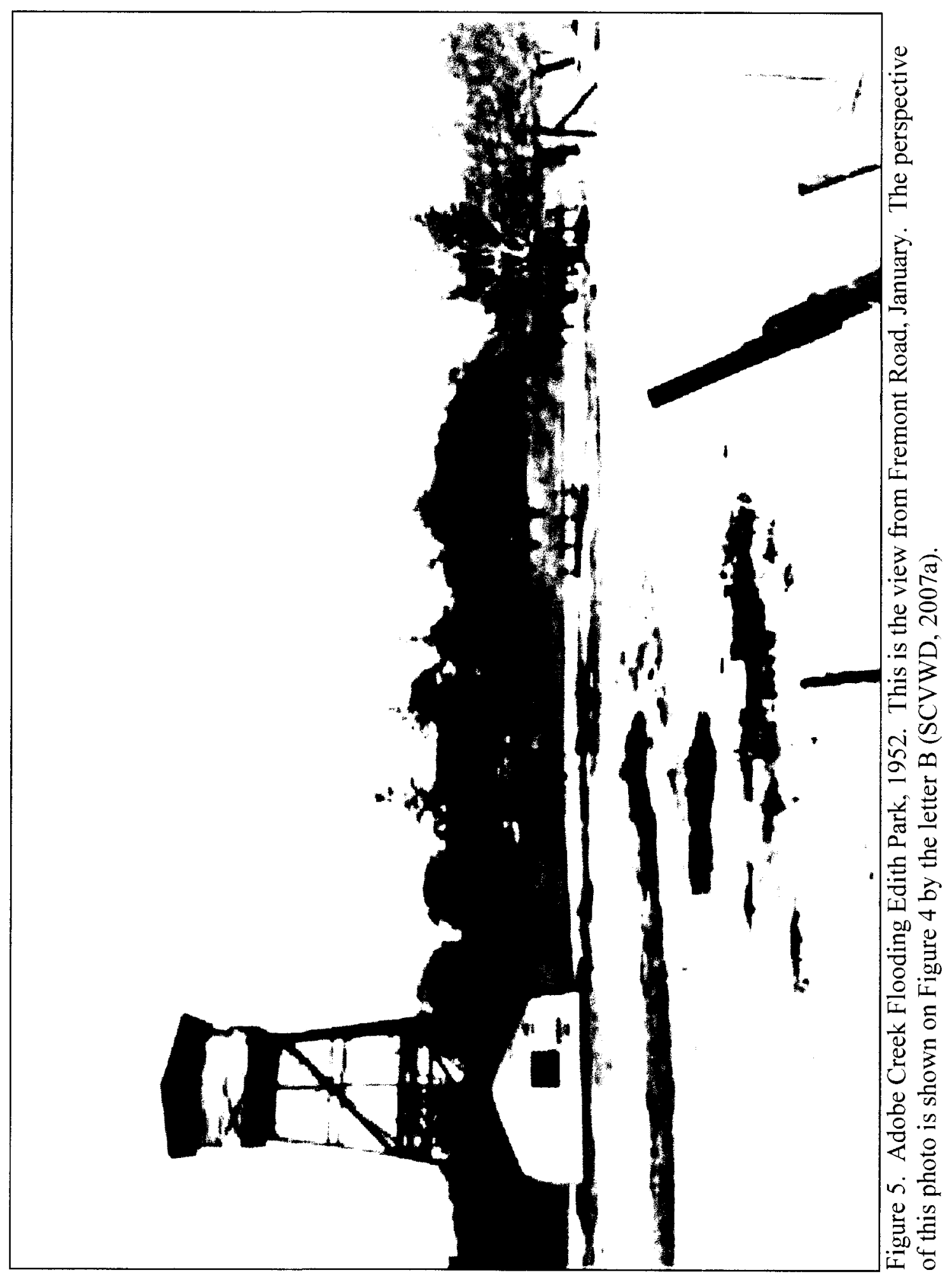


For this design, mitigation was required for the introduction of additional hardscape into the creek. Gabions were to be installed to protect existing mature trees. The District's design included installation of mitigation planting both in the creek and in Edith Park (Figure 3). The design was finished in 2002. In 2003, the plan was rejected by the Los Altos Hills Town Council as they refused to grant the necessary easements to the District (SCVWD, 2007a). Two of the objectionable features of the design were the mitigation planting in Edith Park and the overall design width. Both required easements to be provided to the District in return for increased flood protection. Unsatisfied, creekside residents and concerned locals formed the Adobe Creek Watershed Group (the Collaborative).

In late 2003, the District agreed to assist the Collaborative's effort in developing a new design for Upper Reach 5 (Figure 2). As outlined in the Draft Engineer's Report (SCVWD, 2007a) the following are some of the required components for the new design. The design must provide reduced risk of flooding, protect existing structures through bank erosion stabilization, be aesthetically pleasing, not require mitigation planting in Edith Park, "enhance the creek ecosystem," and the footprint of the project was to remain within the $12 \mathrm{~m}-15 \mathrm{~m}(40 \mathrm{ft}-50 \mathrm{ft})$ wide "blue line limits;" (Figure 6) (SCVWD, 2007a). 


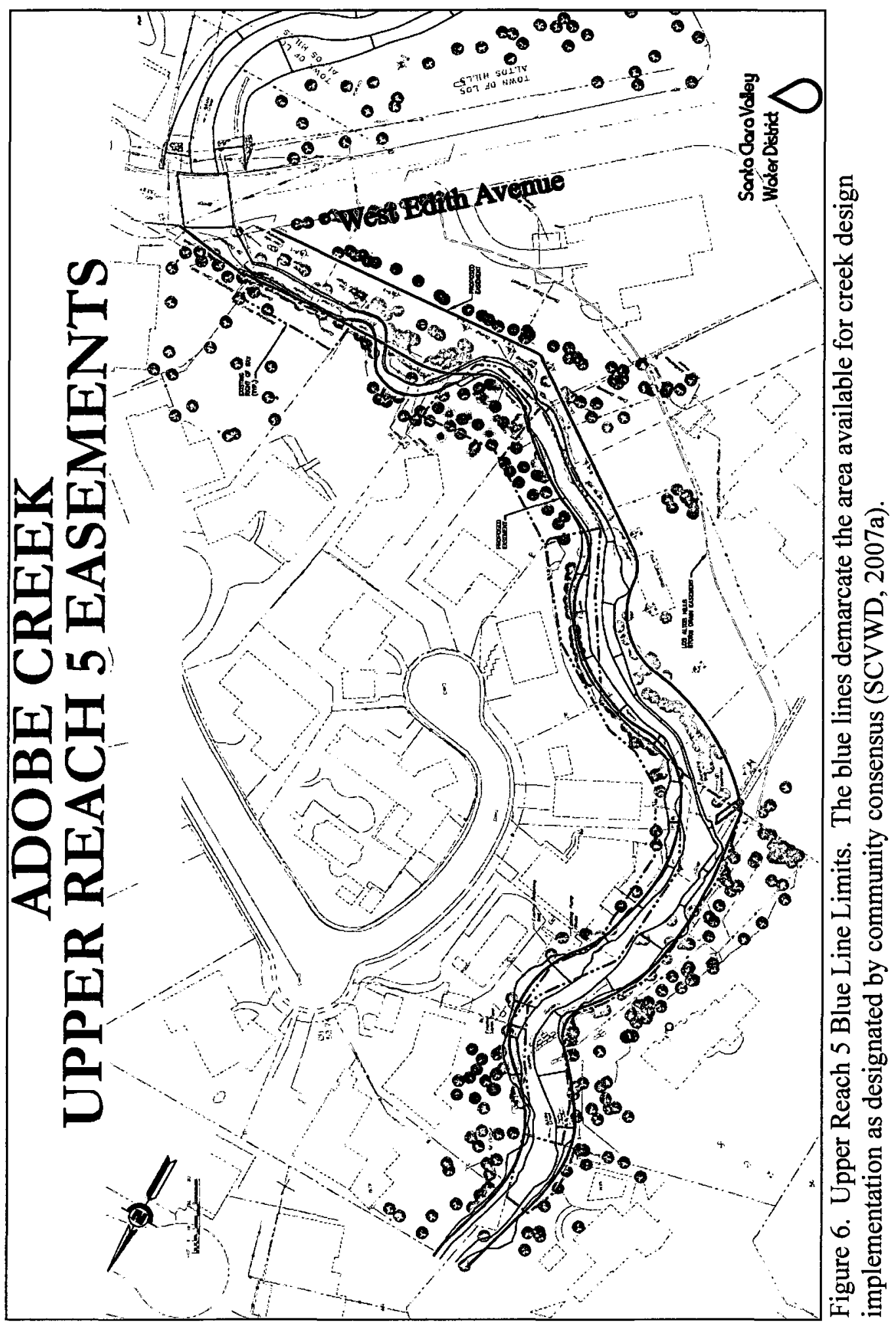




\section{Scope of Research Project}

A system-wide examination of the watershed was needed to understand presentday creek characteristics. The controls of the creek are interdependent, and changes in individual variables result in larger than initiated changes. As detailed by Leopold et al. (1964), the eight variables that dictate creek shape and response are width, depth, slope, flow velocity and discharge, sediment load and composition and hydraulic roughness. Some of the additional aspects researched were: the regional geology; the historical development; transition of the Santa Clara Valley as the agricultural hub to the postwar population center; the resulting change in landuse; water demand within the valley.

\section{GEOLOGIC AND GEOMORPHIC SETTING}

\section{General Location}

Adobe Creek is located in northwestern Santa Clara County, California on the North American Plate. The headwaters are approximately $1.2 \mathrm{~km}(0.75 \mathrm{mi})$ east of the San Andreas fault near Monte Bello Ridge (Figure 7) in the eastern Santa Cruz Mountains about $65 \mathrm{~km}(40 \mathrm{mi})$ south of San Francisco, California (Figure 1). From its source in the mountains above the former Duveneck Ranch (now Hidden Villa), just south of Moody Road (Figure 7), downstream through the Santa Clara Valley to the southern San Francisco Bay at Charleston Slough (Figure 8), the creek is approximately 


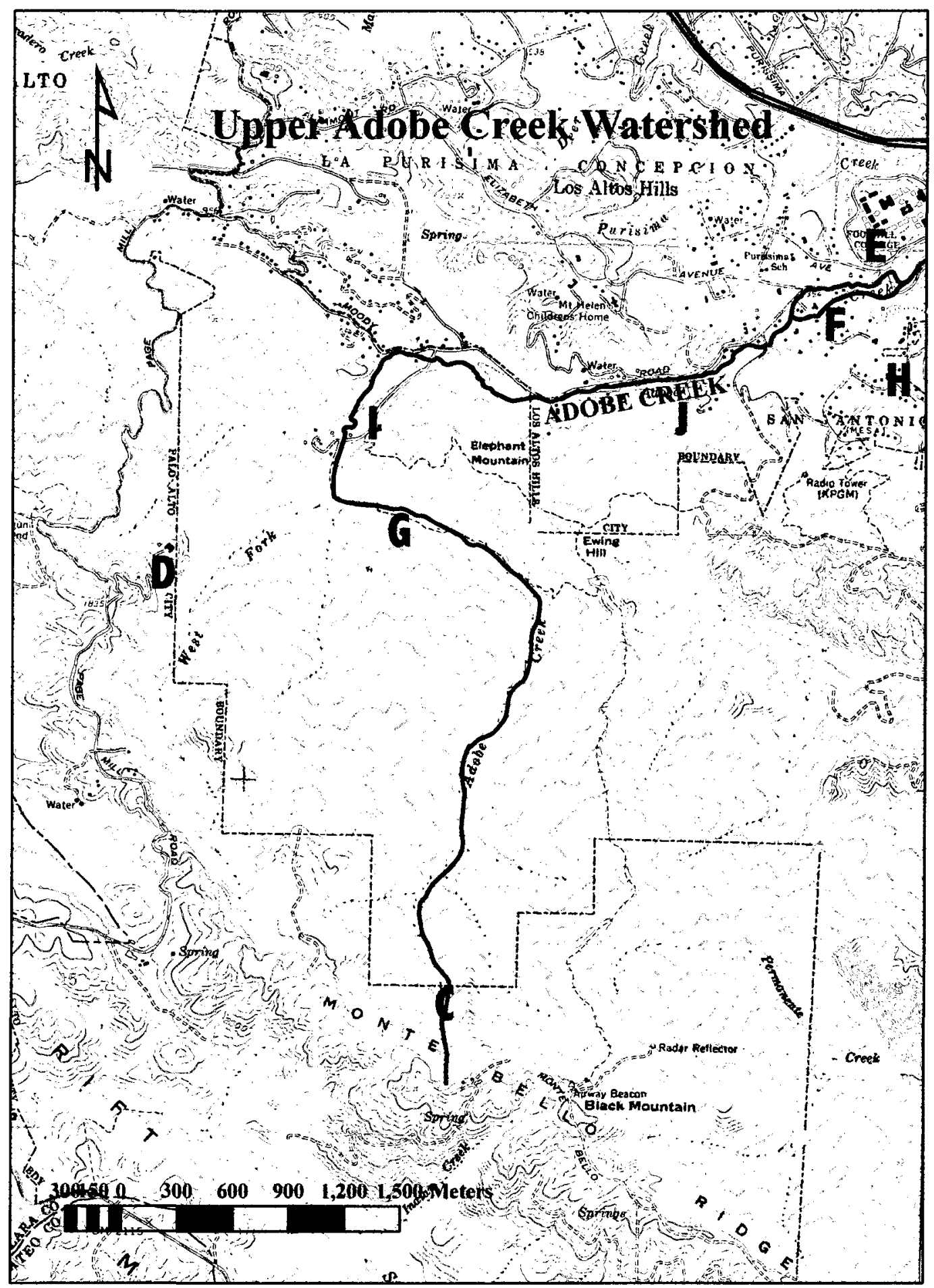

Figure 7. Upper Adobe Creek Watershed. Headwaters are marked with the letter C, the Dahl Ranch Rain Gauge the letter D, E is Foothill College, F is the Adobe Creek Bypass, $\mathrm{G}$ is the beginning of the survey, $\mathrm{H}$ is the approximate location of the Pink Horse Ranch, I is Hidden Villa Ranch, and $J$ is the Adobe Creek Lodge (USGS, 1961). 


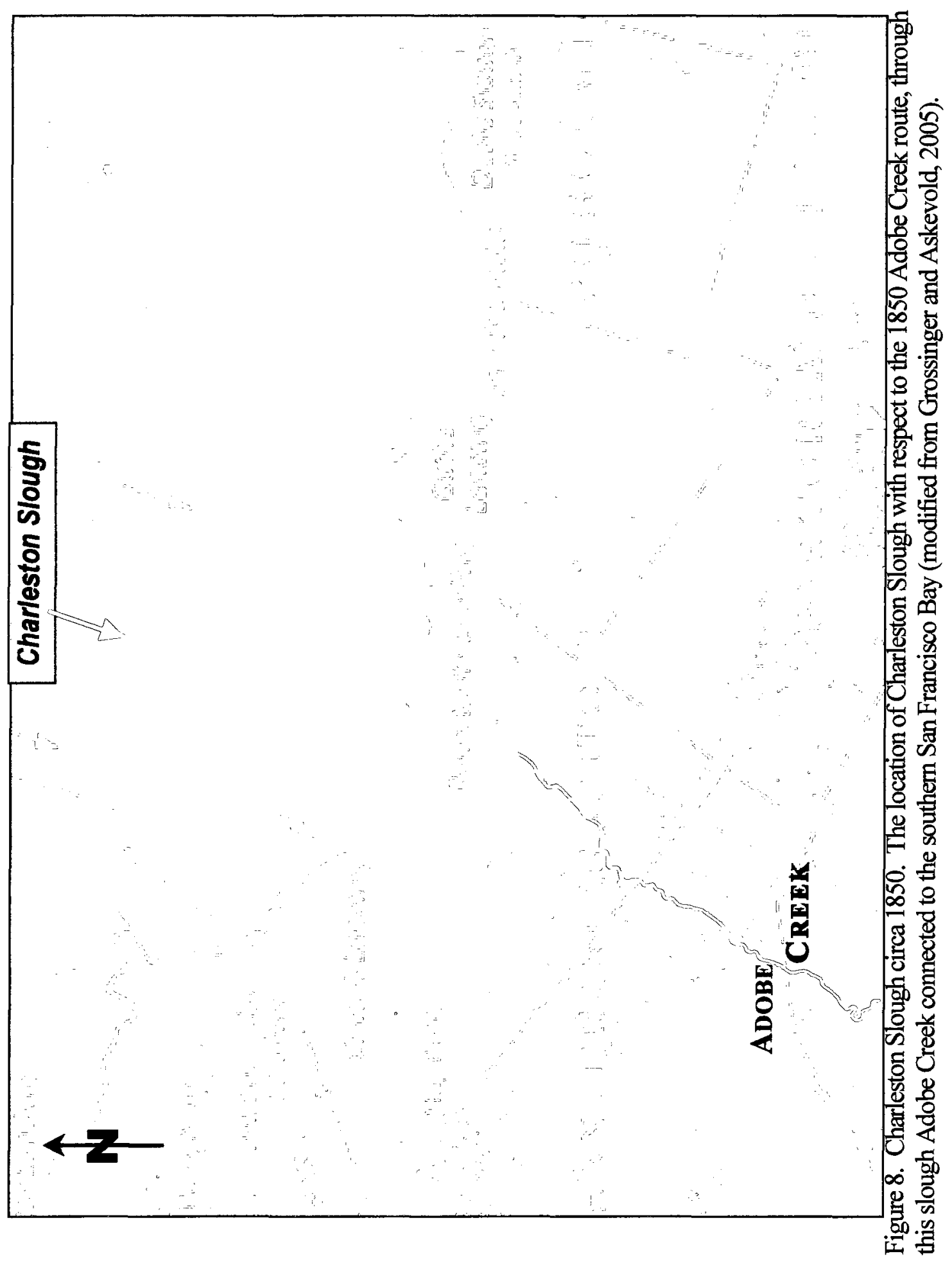


$22.5 \mathrm{~km}$ (14 mi) long. Adobe Creek drains an area of approximately $16 \mathrm{sq} \mathrm{km}(10 \mathrm{sq} \mathrm{mi})$ (SCVWD, 2005). Three quarters of that area is in the foothills; the remaining quarter is in the flatter valley region (SCVWD, 2004a).

Rain controls the flow of Adobe Creek. The Dahl Ranch rain gauge located on the western portion of the upper watershed provides data from the 1966 water year through 2006 (SCVWD, 2007c). Figure 9 shows the annual rainfall fluctuations. The average annual rainfall at the Dahl Ranch rain gauge is $0.8 \mathrm{~m}(31.86 \mathrm{in})$. Figure 10 is a graph of average monthly rainfall at Dahl Ranch. The graph shows the uneven distribution of rainfall throughout the year. The majority (approximately 85 percent) of rain falls between the months of November and March. The annual rainfall decreases eastward to the flatlands. According to the Los Altos Chamber of Commerce, the town receives $0.44 \mathrm{~m}$ (17.4 in) of annual precipitation, approximately a 50 percent decrease from the mountainous regions.

\section{Uplands Geologic Setting}

\section{Carbonate Influence}

Rural landuse in the upper watershed has contributed fewer changes to the creek than suburban landuse areas of the lower watershed. In 1923, the Duveneck family purchased the ranch and land now known as the Hidden Villa Open Space Preserve (Figure 7). In 1936, Josephine and Frank Duveneck opened Hidden Villa Ranch, a nonprofit children's camp, followed in 1937 by the first Youth Hostel in California (Fava, 


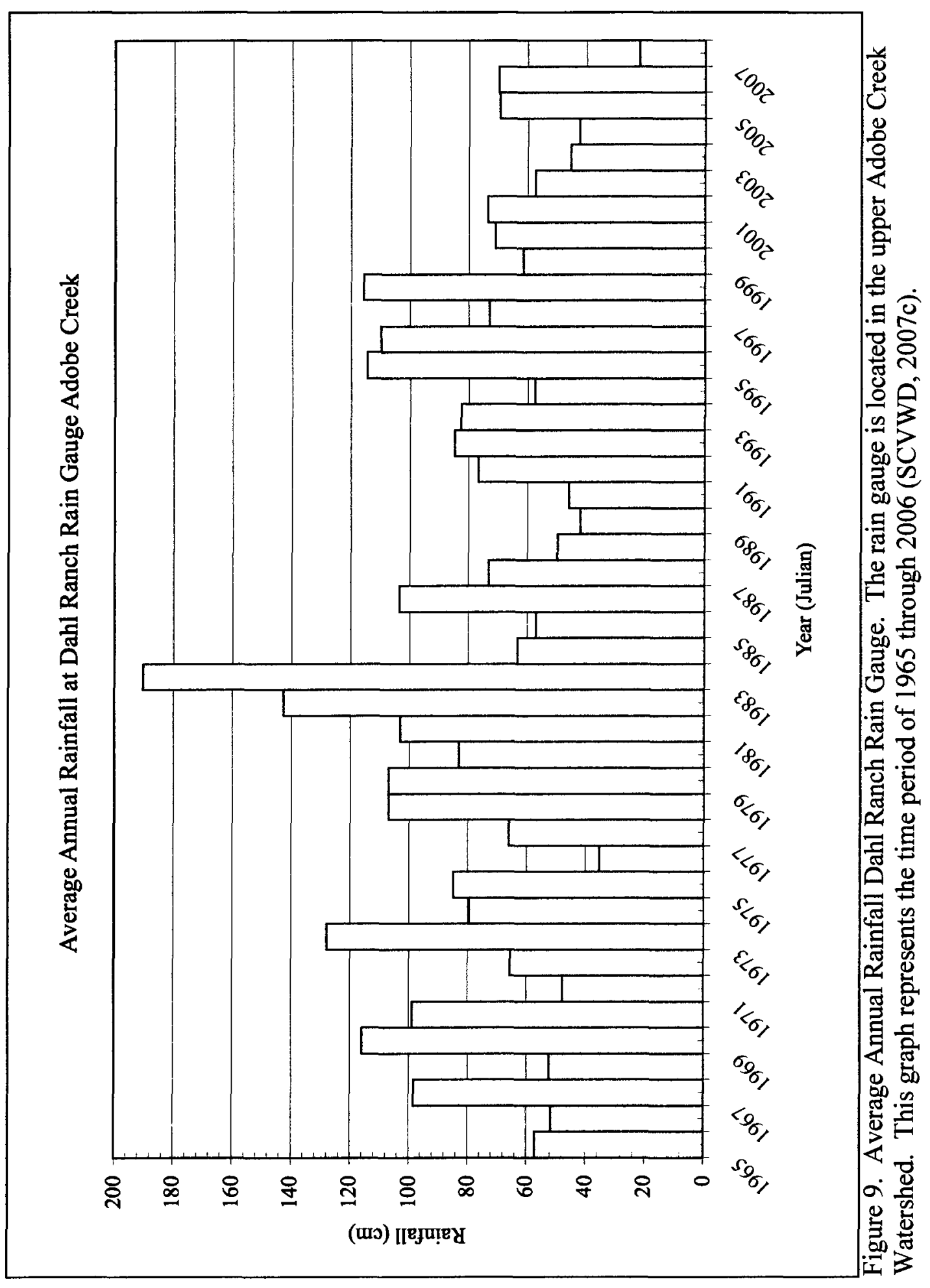




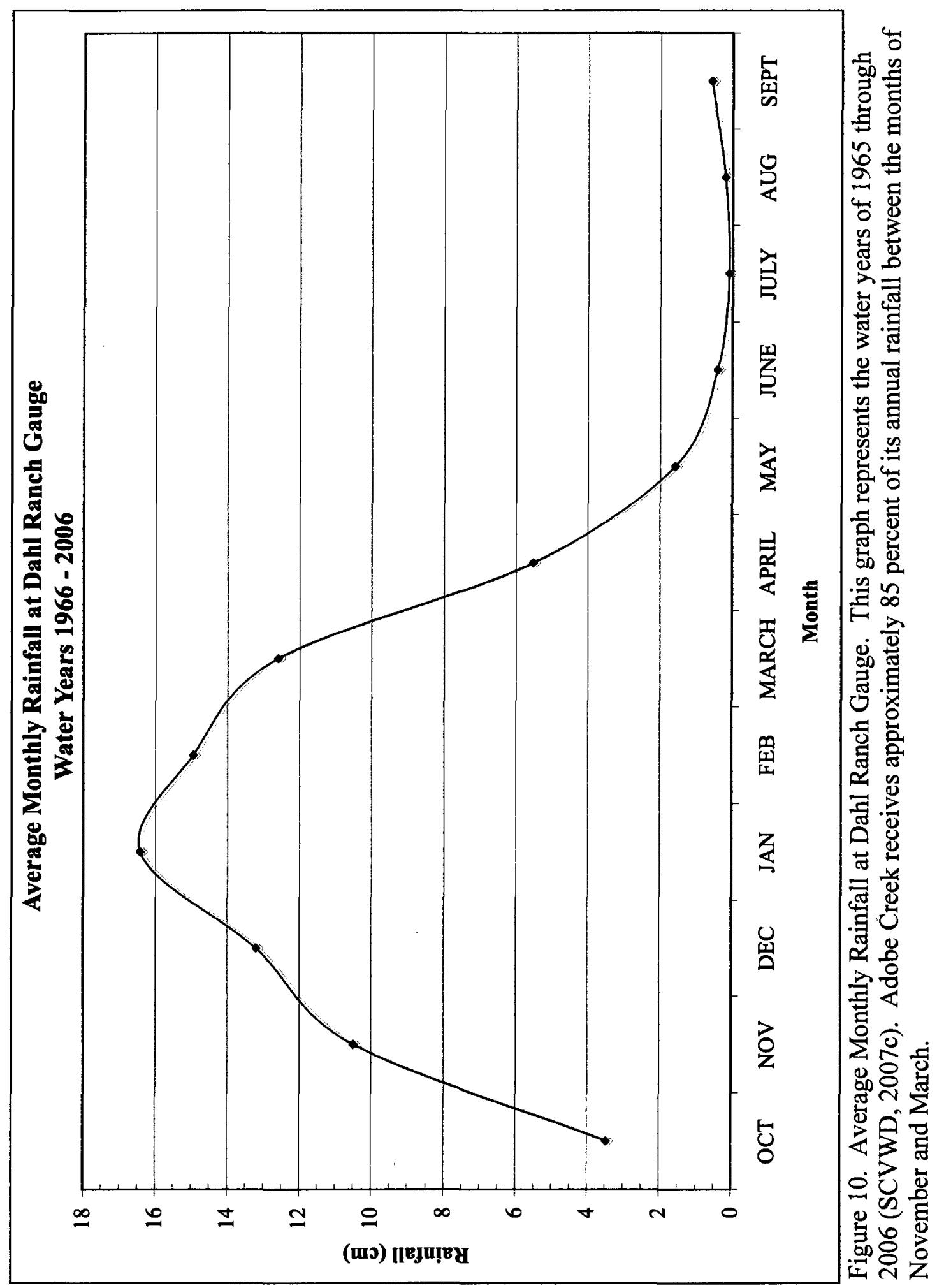


1976). In the past century, the water for the ranch was supplied by a metal diversion pipe. An old rusted metal pipe runs along the creek. In some places the pipe is open and broken. Figure 11 shows the heavy carbonate build-up within the pipe.

In the upper watershed, the creek source is associated with a limestone body, either in the form of the Franciscan Limestone (fl) (Figure 12) beneath the Franciscan Sheared Rock Mélange (fsr), or as a lens or block within the fsr. According to Brabb, Graymer, and Jones (2000) the fl within the Franciscan Complex (KJf) usually occurs within a pocket of greenstone ( $\mathrm{fg}$ ), which supports the concept of a lens of limestone. The creek path is confined by an indurated streambed. A positive feedback system has developed from the dissolution of limestone bedrock followed by the downstream precipitation. Dissolved carbonate minerals are transported to the surface from the underground source and then reprecipitated as the water moves over the substrate. The water contains carbonate minerals that encrust and encase transitory forest debris in a thick shell that resembles cave dripstone. Figures 13 and 14 shows leaves and twigs encapsulated by carbonate minerals. Figure 15 is a photograph of the source of Adobe Creek at an elevation of approximately $683 \mathrm{~m}$ (2240 ft). The carbonate-infused creek water flows over the hardened streambed to further perpetuate the channelization. Adobe Creek water chemistry data are provided in the 1964 Water Supply Investigation conducted by the State Department of Public Health. The most upstream sampling site was at Adobe Creek Lodge (Figure 7). The water hardness at the sampling sites increased in the downstream direction, reaching a maximum hardness of $381 \mathrm{mg} / \mathrm{l}$ at Shoup Park (Figure 3). See Table 1 for the results. 


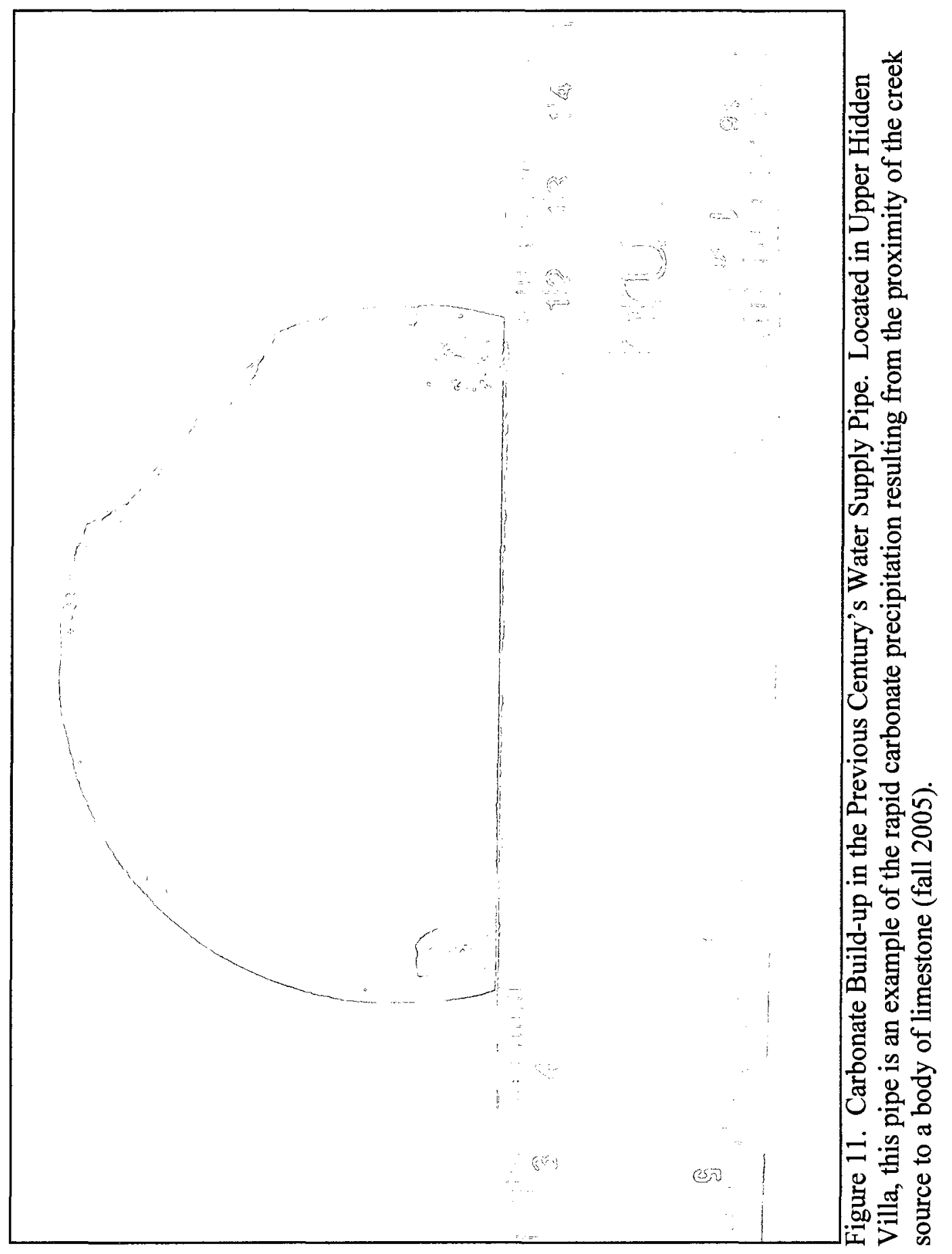




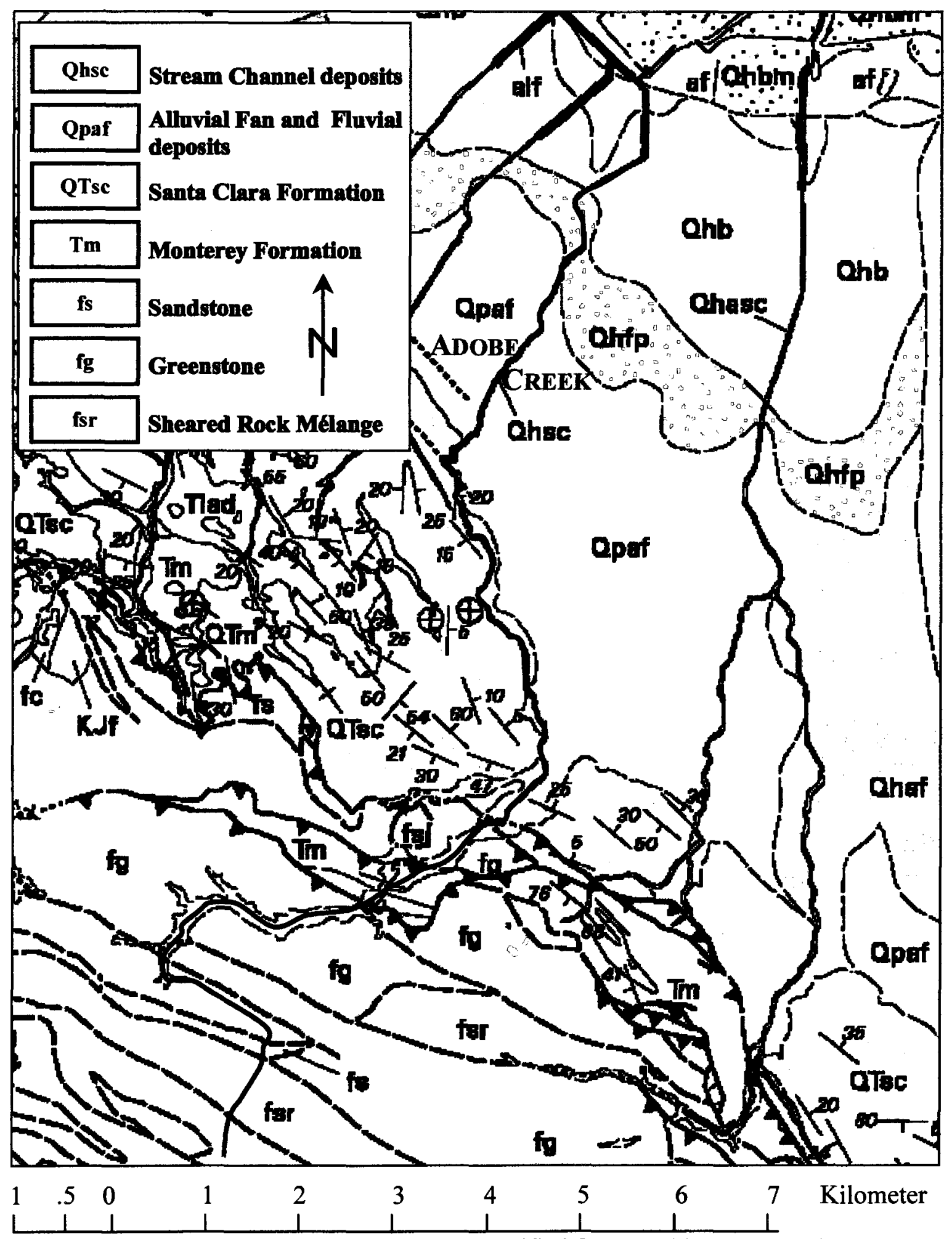

Figure 12. Geologic Map of Adobe Creek (modified from Brabb et al., 2000). 


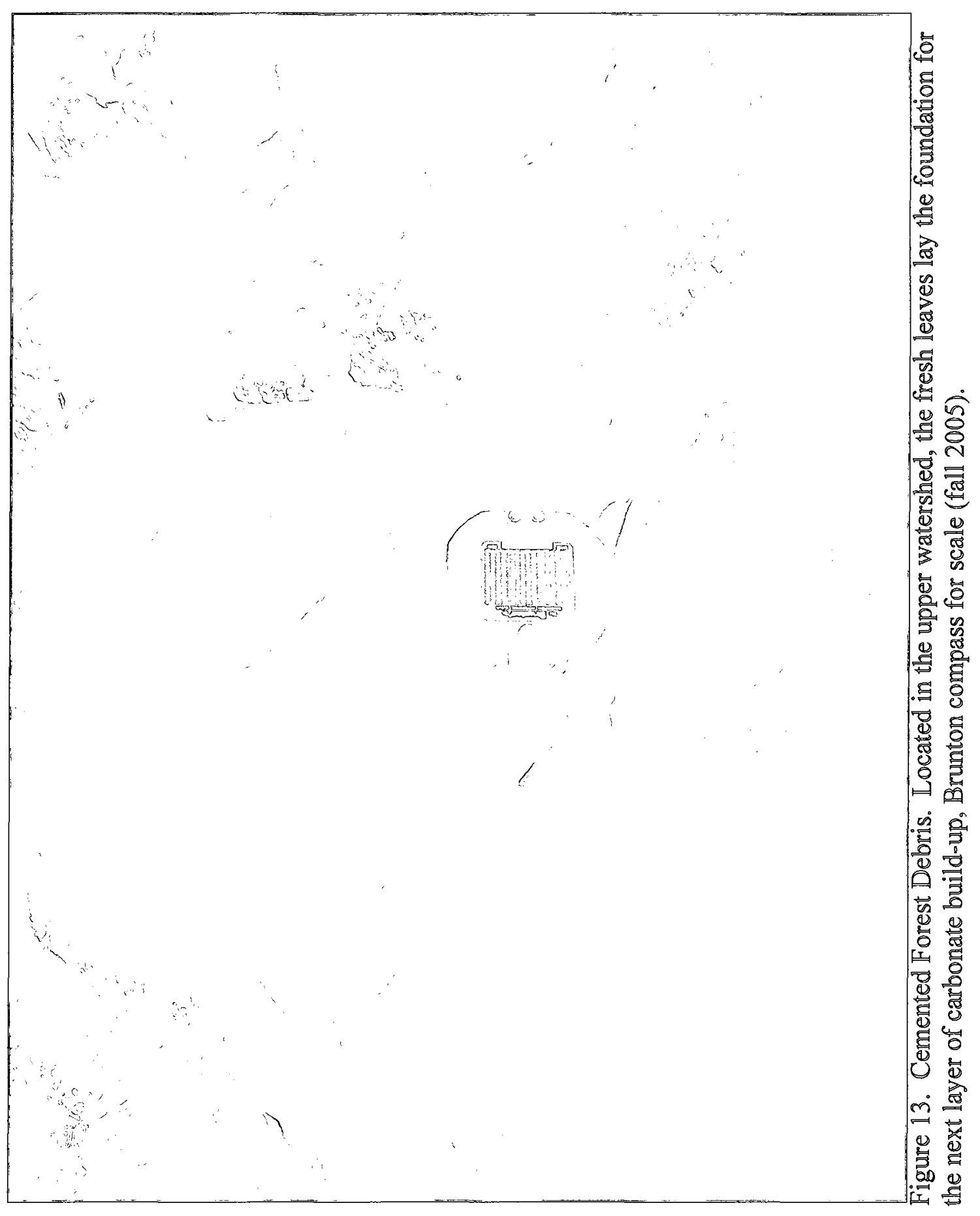




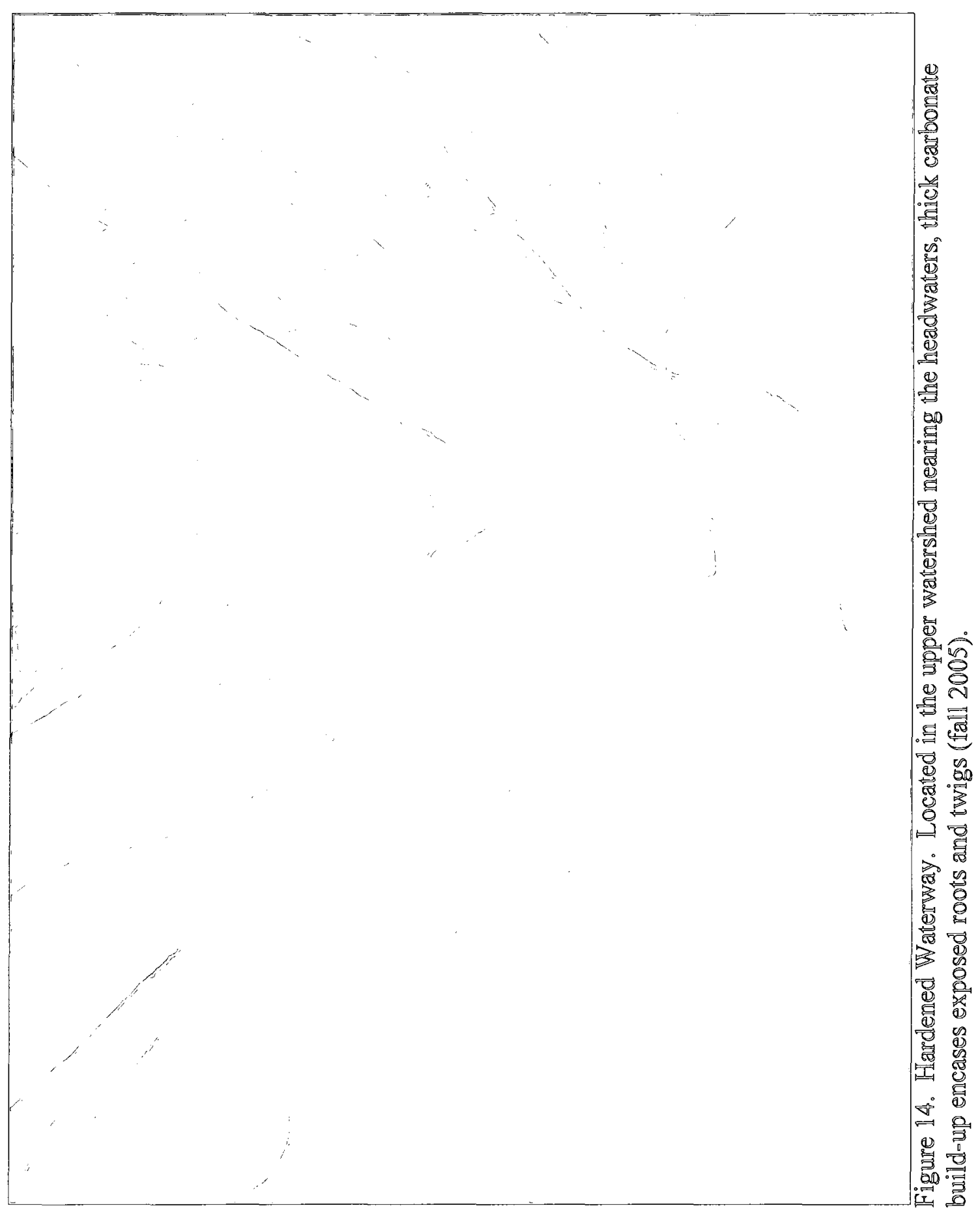




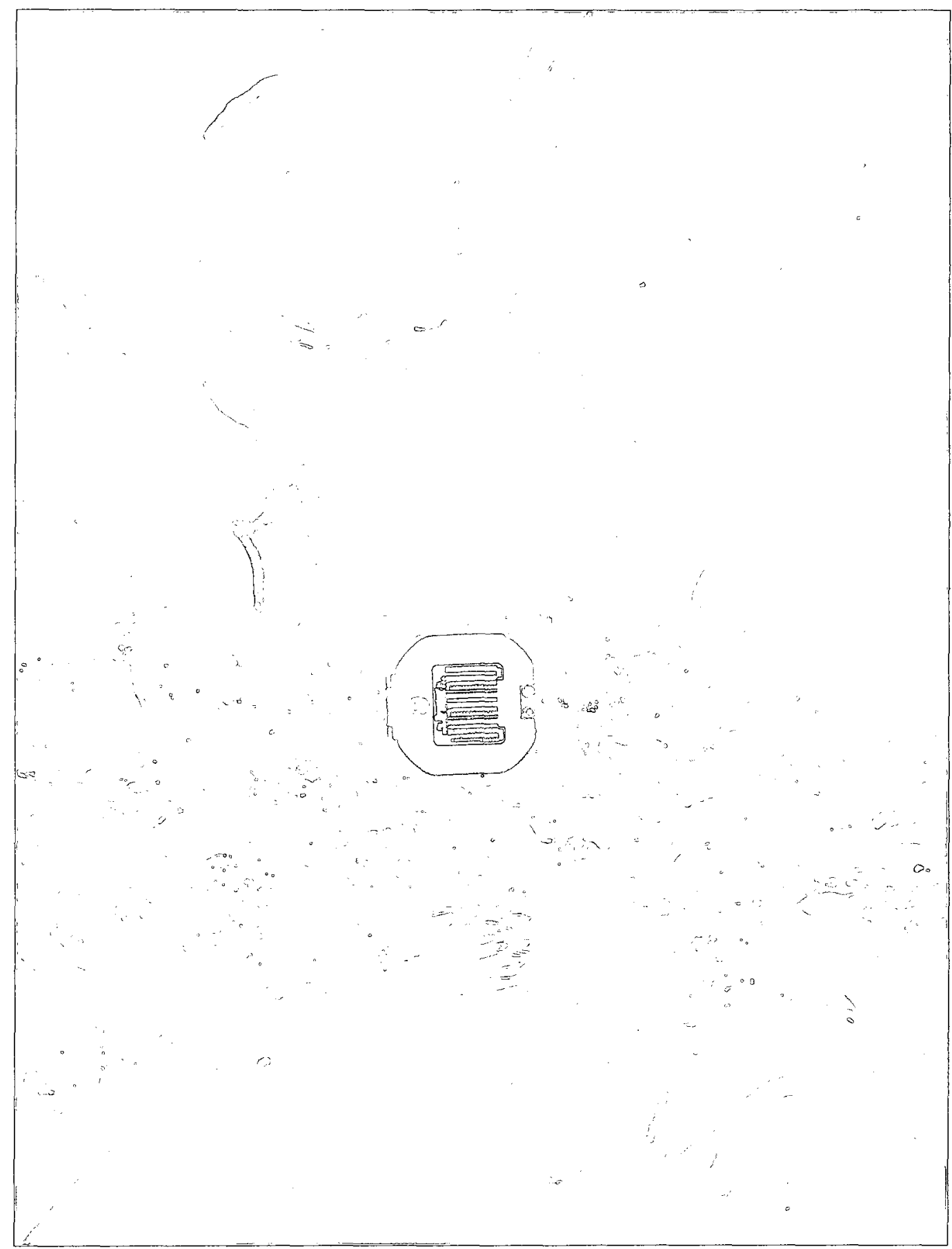

Figure 15. Adobe Creek Source. Water seeping from the ground source at an elevation of $683 \mathrm{~m}$ (2240 fit), Brumton compass for scalle (fall 2005). 


\begin{tabular}{|c|c|}
\hline Creek Locations & Hardness mg/l \\
\hline Adobe Creek Lodge & 265 \\
\hline Adobe Creek at Moody Road & 291 \\
\hline Tepa and Moody Way & 302 \\
\hline Adobe Creek upstream of Foothill College & 287 \\
\hline Adobe Creek downstream of Foothill College & 292 \\
\hline Adobe Creek at O'Keefe Avenue & 353 \\
\hline Adobe Creek $76 \mathrm{~m}(250 \mathrm{ft})$ upstream of Shoup Park & 359 \\
\hline Adobe Creek at Shoup Park & 381 \\
\hline Well Location & Hardness mg/l \\
\hline Van Buren Well No. 2 & 142 \\
\hline
\end{tabular}




\section{Natural Segmentation}

In the upper reaches of the stream, the well-armored bed has limited the meander development and allowed minimal change of course during low-flow conditions. During large-scale rain events, the creek would not be as hampered by its predetermined course as it would inundate a larger swath and have enough energy to create new paths, or as high flows receded, new paths could develop. The carbonate cementation limits the sediment load the headwaters contribute to the system.

In most creeks, the bulk of the erosion occurs in the steepest reaches. Adobe Creek is different in that under normal low-flow conditions sediment-starved water comes out of the steepest reaches and erodes lower in the watershed where it is not armored by the carbonate build-up. Unlike other creeks, Adobe Creek cannot adjust or regrade itself all the way to the headwaters. The area where adjustments can occur has been limited, creating natural creek segmentation. In Adobe Creek, segmentation indicates the inability of a creek to transfer changes up or downstream of a specific location in the form of erosion or aggradation.

\section{Tectonism}

The Santa Clara Valley is bounded by the Santa Cruz Mountains on the west and the Diablo Range on the east. It is a structural trough between the San Andreas and Hayward faults (Figure 16) (Poland, 1984). In plan view, the valley has a ' $v$ ' shape. The east and west foothills converge on the valley's southern boundary to form the Coyote 


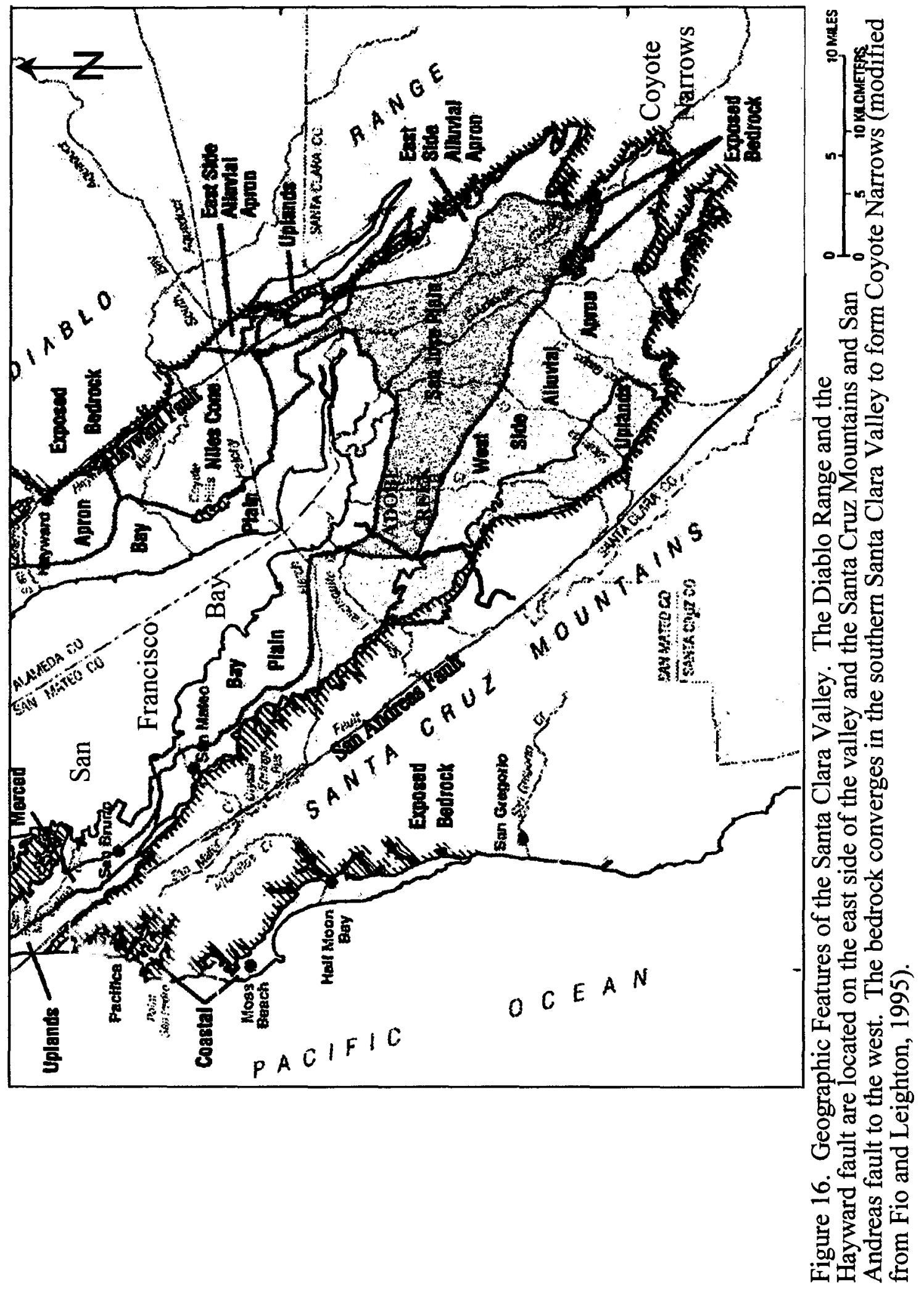


Narrows. The Narrows serve as the drainage divide between the San Francisco and Monterey bays (Sloan, 2006) (Figure 16).

\section{Fault Bound Assemblages}

The San Andreas fault (SAF), the youngest and most recently active fault in the area demarcates the western boundary of the intensely and complexly faulted Woodside Assemblage (Figure 17). It is within this assemblage that the upper watershed's westernmost $9.7 \mathrm{~km}(6 \mathrm{mi})$ of creek is situated. In the lower watershed, the remaining northern $12.9 \mathrm{~km}(8 \mathrm{mi})$ of creek crosses Quaternary cover.

The Woodside Assemblage is one of ten fault-delimited blocks depicted by Brabb, Graymer, and Jones on their Palo Alto 30-minute quadrangle map of 2000. As introduced by Graymer, Jones and Brabb in 1994, assemblages or blocks are distinguished by contrasting stratigraphic sequences and are based on diverse lithologies bound by regional faults (Figure 18). In the area of Adobe Creek, the assemblage consists mainly of the Franciscan Complex (KJf) (Figure 12).

For unknown reasons, the faults that separate the blocks in the Palo Alto map area have a northeasterly younging trend. In the southern portion of Brabb's 2000 map, south of Adobe Creek, most of the activity along the Zayante fault is shown as completed by the late Miocene. However, according to Coppersmith (1990) there is evidence of minor Holocene movement. Similarly, northeastward, the majority of the displacement along the Butano fault was finished near the end of the Miocene to the beginning of the 


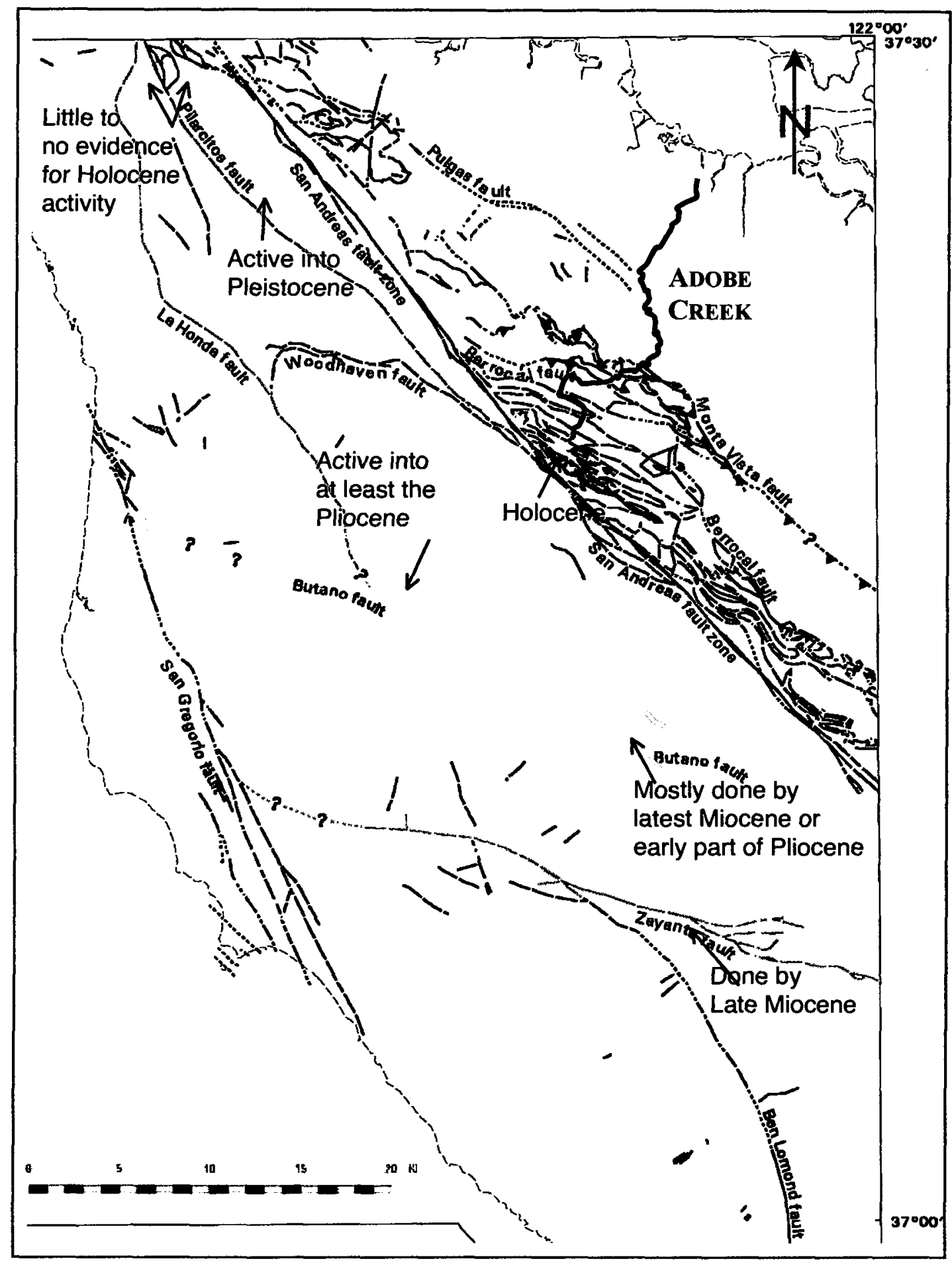

Figure 17. Regional Faults. This map shows the northeast younging trend of faults in the region of Adobe Creek. The creek is situated east of the San Andreas fault within the reverse range-front faults in the eastern Santa Cruz Mountains (modified from Brabb et al., 2000). 


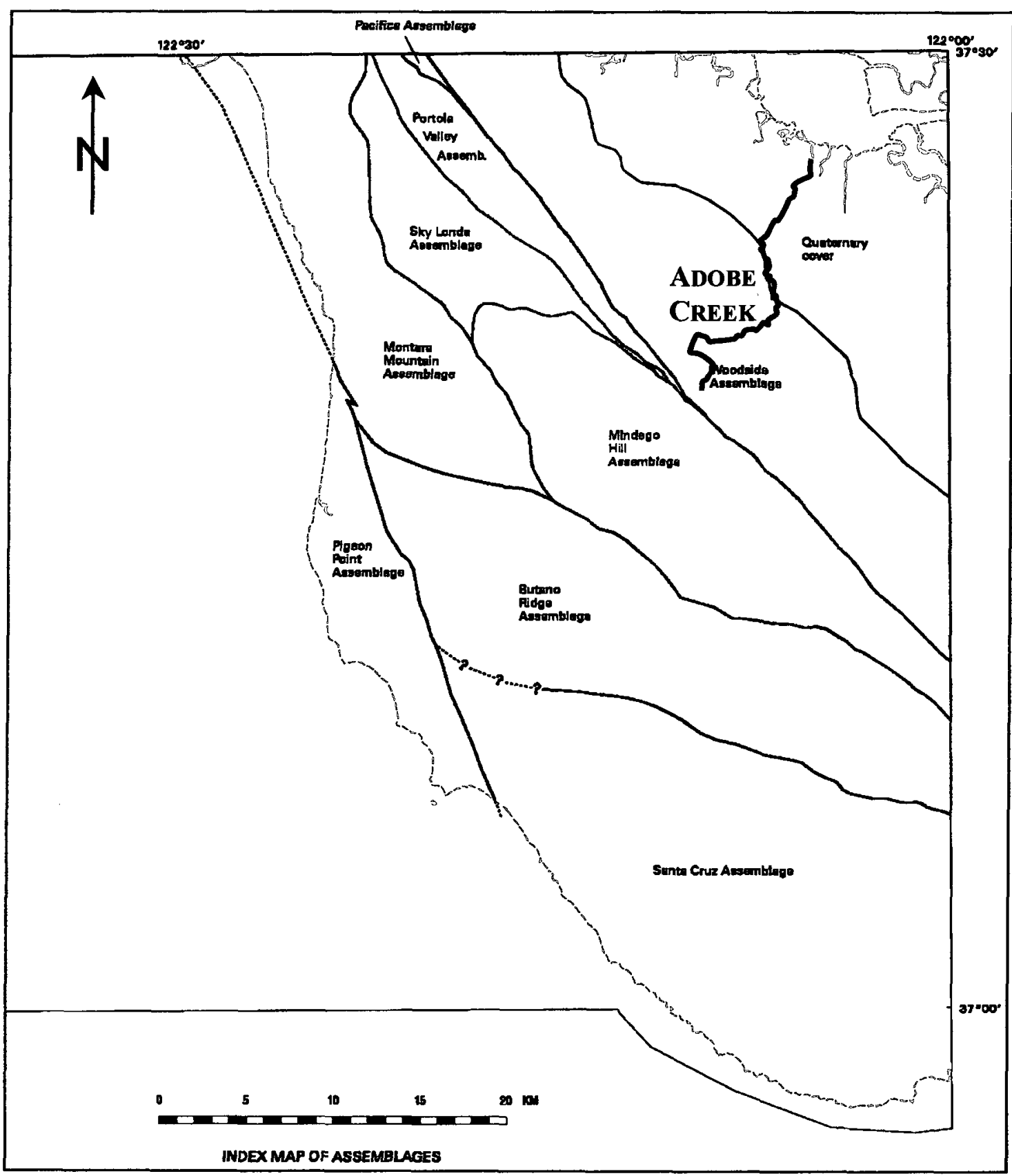

Figure 18. Assemblages of Adobe Creek. Adobe Creek begins in the Woodside Assemblage and flows northeast across Quaternary cover (modified from Brabb et al., 2000). 
Pliocene. The La Honda and Pilarcitos faults continue the northward trend with final displacements during the Pliocene and Pleistocene, respectively (Brabb et al., 2000).

The San Andreas fault has been closely associated, if not directly involved with much of the Holocene faulting in the Santa Clara Valley. The 1906 and 1989 earthquakes provide contemporary examples of the potential range in magnitude of a future event. Both events caused catastrophic damage, however the 1906 event released between 16 (Stoffer, 2005) and 30 (Bolt, 1993) times the energy of the 1989 Loma Prieta earthquake. Strong ground shaking of the 1906 event lasted approximately 45 to 60 seconds and had a rupture length of $482 \mathrm{~km}$ ( $300 \mathrm{mi})$. The strong ground shaking of the 1989 Loma Prieta event lasted 10 to 15 seconds and had a rupture length of $40 \mathrm{~km}$ ( 25 mi) (Stoffer, 2005).

The influence of the San Andreas fault (SAF) is reflected in the creek's plan form angular drainage pattern (Figure 17). Strike-slip faults appear to influence creek pattern in the $x$ and $y$ direction, as the creek tends to flow approximately perpendicular or parallel to the San Andreas fault (SAF). This is not a captured stream since the bedrock and topography exclude this potentiality; instead the creek has exploited geologic weaknesses at lithologic boundaries that are results of tectonism. The creek is responding to secondary conditions resulting from tectonism rather than direct tectonic activity. One example of secondary consequences are located in the upper watershed which contains a series of unnamed discontinuities where the Franciscan Greenstone (fg) and Sheared Rock Mélange (fsr) appear as interspersed slivers (Figure 12). Though many lithologic boundaries have been mapped, it is possible that Adobe Creek is following a weakness at 
a lithologic boundary that has yet to be discovered, since the creek path is more angular through the upper watershed bedrock.

\section{Range-Front Faults}

Downstream, east of the unnamed discontinuities, there are a complex series of reverse range-front faults. These faults, the Monte Vista, Berrocal, and others juxtapose the Jurassic Franciscan Greenstone (fg) with three different units: the Miocene Monterey Shale (Tm), the Franciscan Sandstone (fs) and the Tertiary Santa Clara Formation (QTsc) (Figure 12). The range-front faults could be expressions of a fault system that joins the SAF at depth, or they may be structurally discrete and represent the source of their own seismic activity (Langenheim, Schmidt, and Jachens, 1997) (Figure 19). The relationship between the SAF and these range-front reverse faults is not well understood and the exact mechanisms are a matter of debate. Either answer allows the faults to accommodate a component of the compression created from the strike-slip faults on either side on the valley.

Displacement along these reverse faults or along the large-scale assemblagebounding faults results in creek gradient changes. These natural modifications or controls maintain the creek in a state of disequilibrium (Hitchcock, Kelson, and Thompson, 1994) (Figure 20). This state of disequilibrium is different from the state of dynamic equilibrium maintained by a well-functioning creek. Dynamic equilibrium is defined as "the average condition of a river during its relatively recent history" (Riley, 1998, p. 126). Dynamic equilibrium is a self-perpetuating state constantly undergoing 


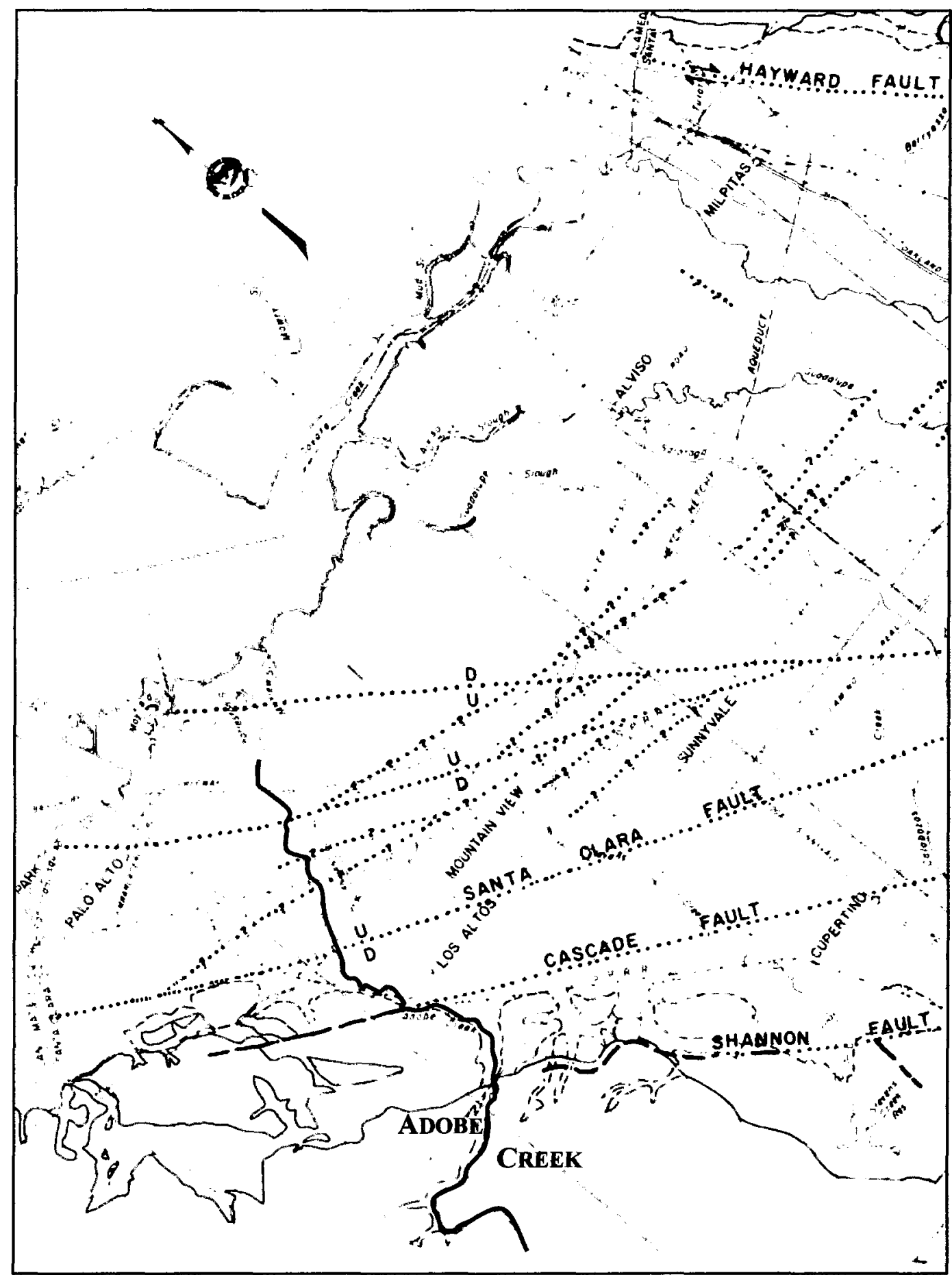

Figure 19. Reverse Range-Front Faults, 1975. The influence of reverse faults on creeks is more evident in the $z$-axis, where as strike-slip movement is more recognizable in plan form (modified from California Department of Water Resources, 1975). 


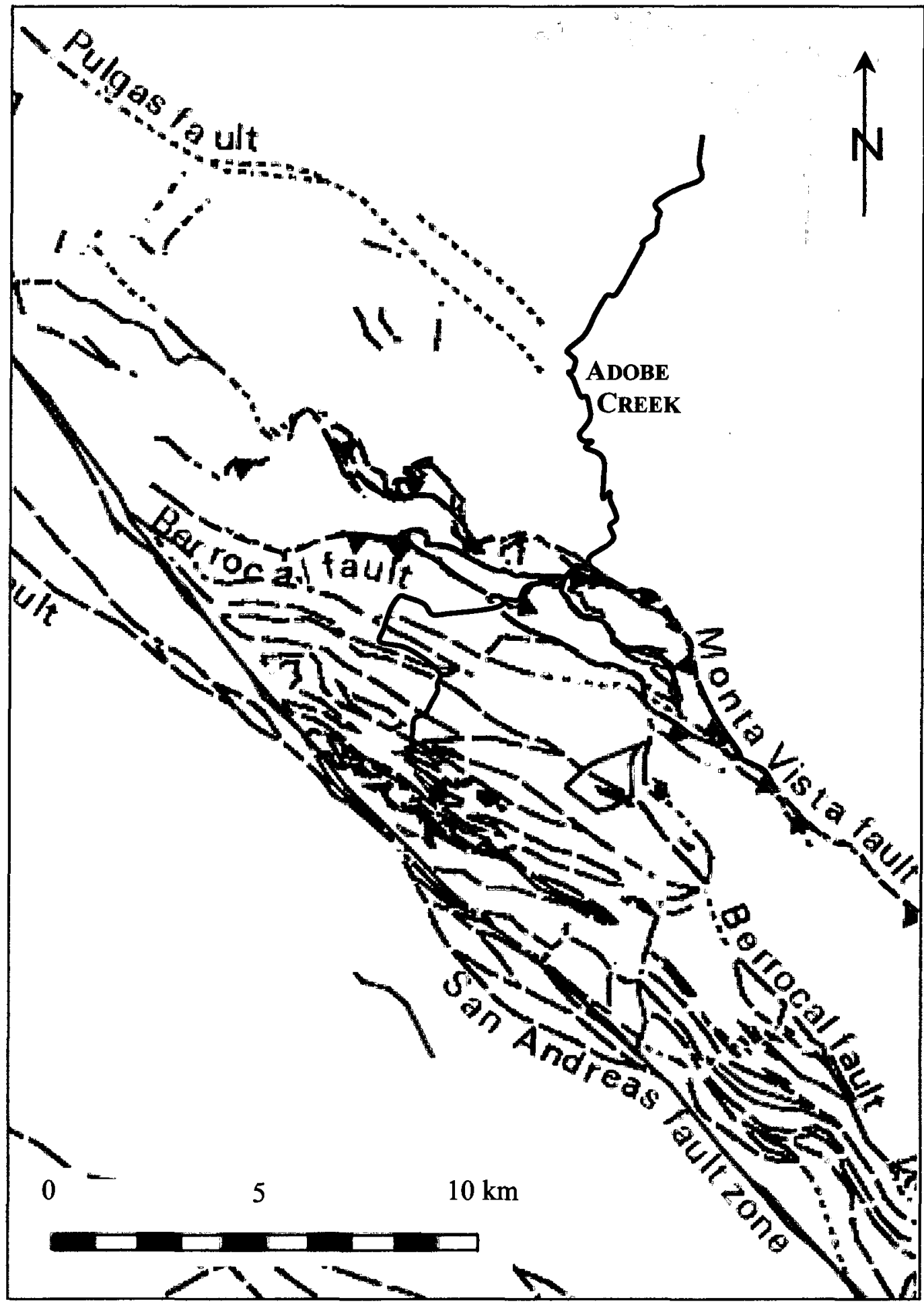

Figure 20. Reverse Range-Front Faults, 2000. The Monte Vista and Berrocal faults are two of the complex faults in the upper watershed (modified from Brabb et al., 2000). 
adjustments to the continual cycle of erosion and deposition. Generally, as creeks erode their bed and banks, downstream sedimentation of eroded material eventually leads to a shallower slope. The decrease in slope causes a decrease in competence that then contributes to the creek bed aggrading. This positive feedback loop enhances the aggradation until the creek bed slope becomes too shallow to maintain its current levels of flow and sediment transport. Once this critical juncture has been reached, the result of possible outcomes depends on precipitation, sediment type, and supply.

Evidence of tectonically influenced creek geometry depends on the dominant type of ground displacement. Movement along the reverse faults is most evident in the $z$-axis or along the longitudinal profile of the creek. The slope change disrupted the creek equilibrium. At fault crossings, the creek's longitudinal profile is convex; one example is shown on Figure 21.

Since the difference in the rate of change is so vast between the immediate and geologically short-lived action of earthquake-induced ground displacement and the slower processes of incision and channel development, there is a lag time for which the creek attempts to catch-up and maintain its dynamic equilibrium. For example, the late Cenozoic uplift of the Santa Cruz Mountains rejuvenated the creeks by the increase in stream gradient, which increased the supply of Franciscan material (Stanley et al., 2002). 


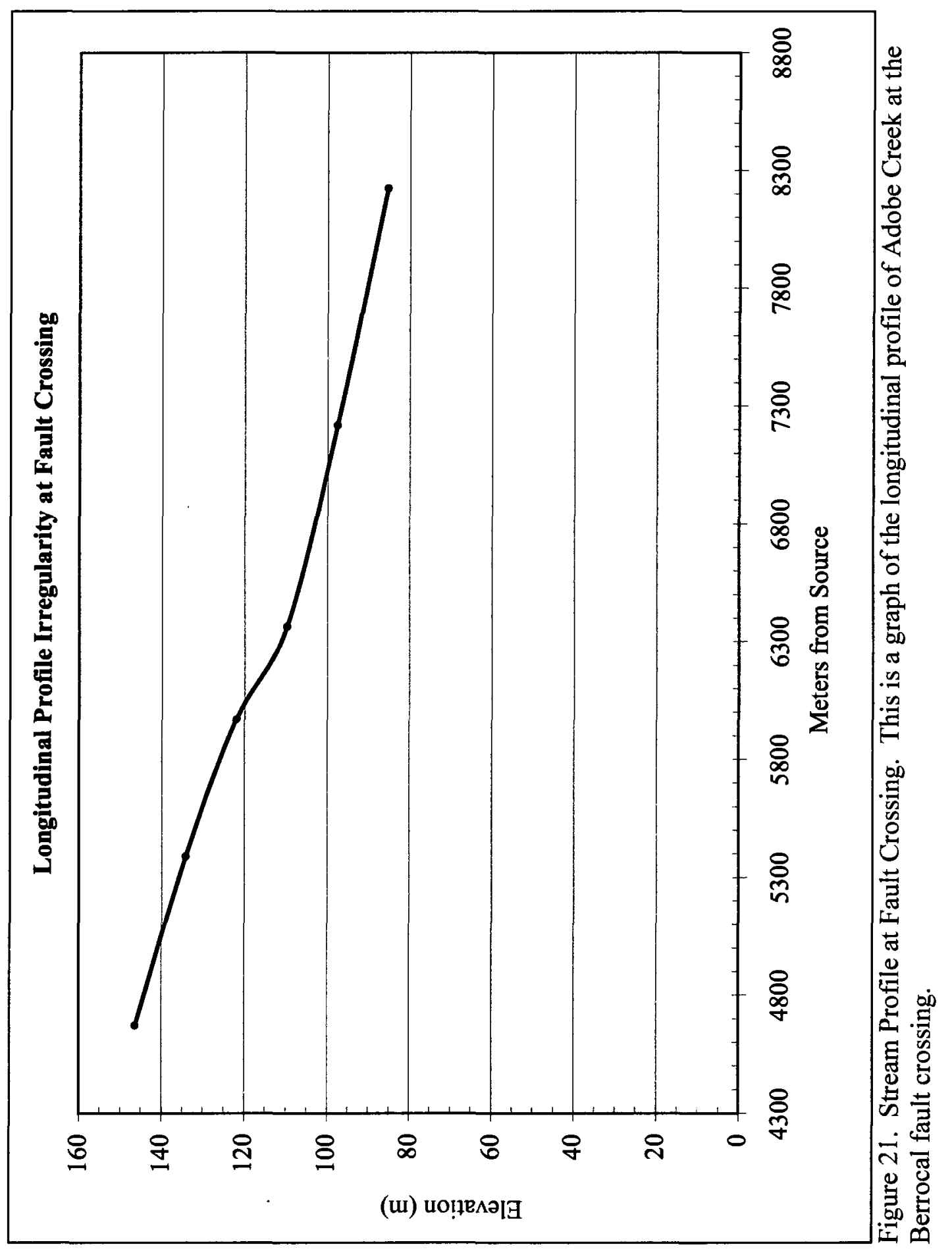




\section{Valley Fill Materials and Subsurface Geology}

\section{Alluvial and Fluvial Deposits}

The Santa Clara Valley is filled with Pleistocene (Qpaf) and Holocene (Qhsc, Qhfp and Qhaf) alluvial and fluvial deposits (see Figure 12). These consist of layered sands and gravels with interspersed layers of clay. The layered sands and gravels are associated with modern stream paths, and are derived from the surrounding mountains. The local ranges have provided much of the approximately $460 \mathrm{~m}(1500 \mathrm{ft})$ of sediment that fills the valley (Brabb et al., 2000). The coarser layers are water-bearing units. They were deposited during one of the interglacial periods of the Pleistocene (Oakeshott, 1971) when sea level was low enough that creeks and rivers flowed across the valley to reach the ocean. Layered within the coarser materials are irregularly-spaced, fine-grained mud, clay and silt. These were deposited during periods of higher-than-present sea level elevations that inundated the northern portion of the valley (Sloan, 2006). Figure 22 is the location map of the cross-section shown on Figure 23.

The Pleistocene alluvial fan deposits (Qpaf) thin and grade toward the bay and into the more impermeable Holocene flood-plain deposits (Qhfp). The Pleistocene deposits display a more developed soil profile than those of the Holocene. The Holocene deposits are less dissected than the topographically higher Pleistocene deposits (Brabb et al., 2000). The lack of folding and deformation distinguishes these younger layers from the underlying Santa Clara Formation (QTsc) (Brabb et al., 2000). 


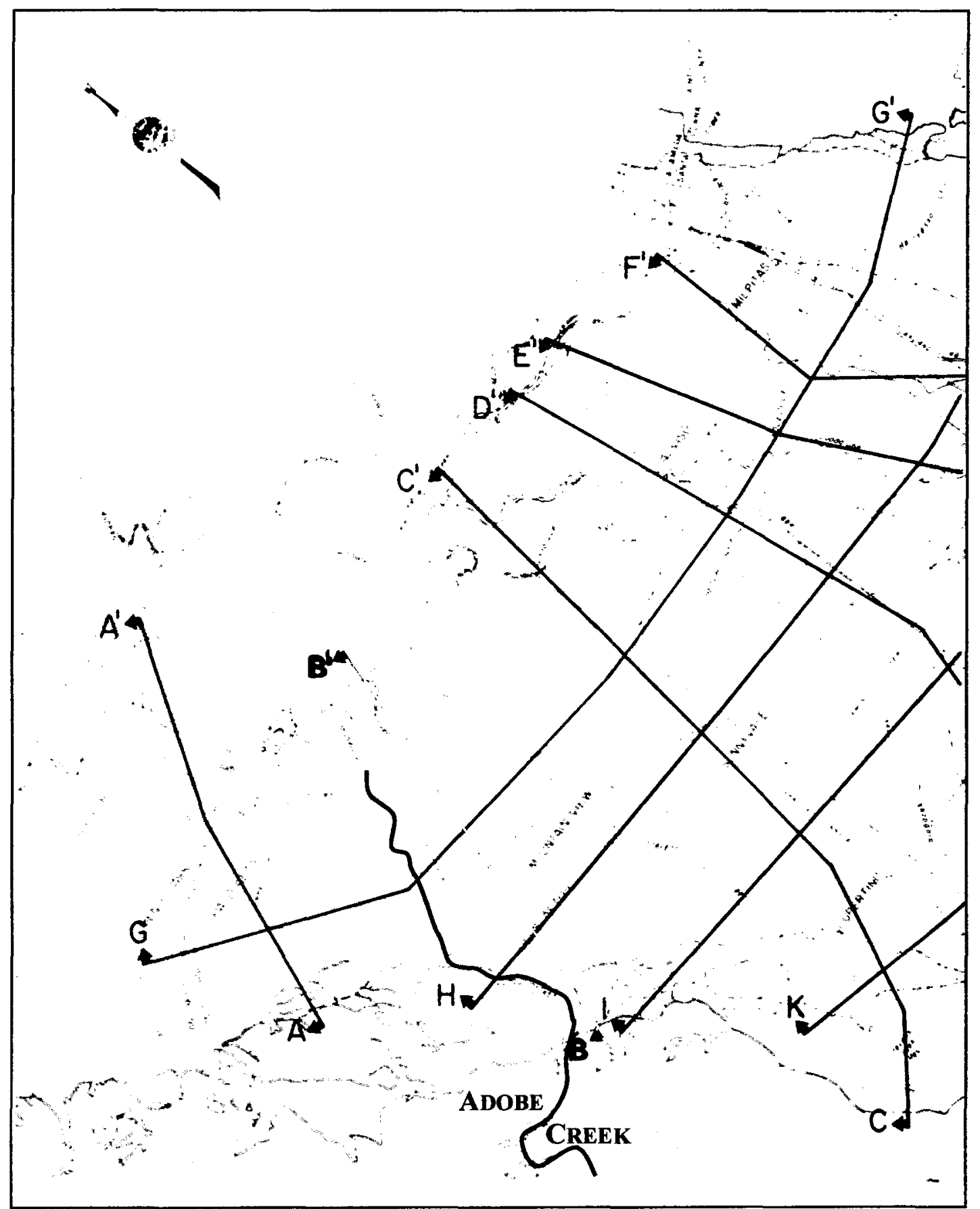

Figure 22. Location of Cross-Section Along B-B'. The cross-section closely parallels Adobe Creek (modified from California Department of Water Resources, 1975). 


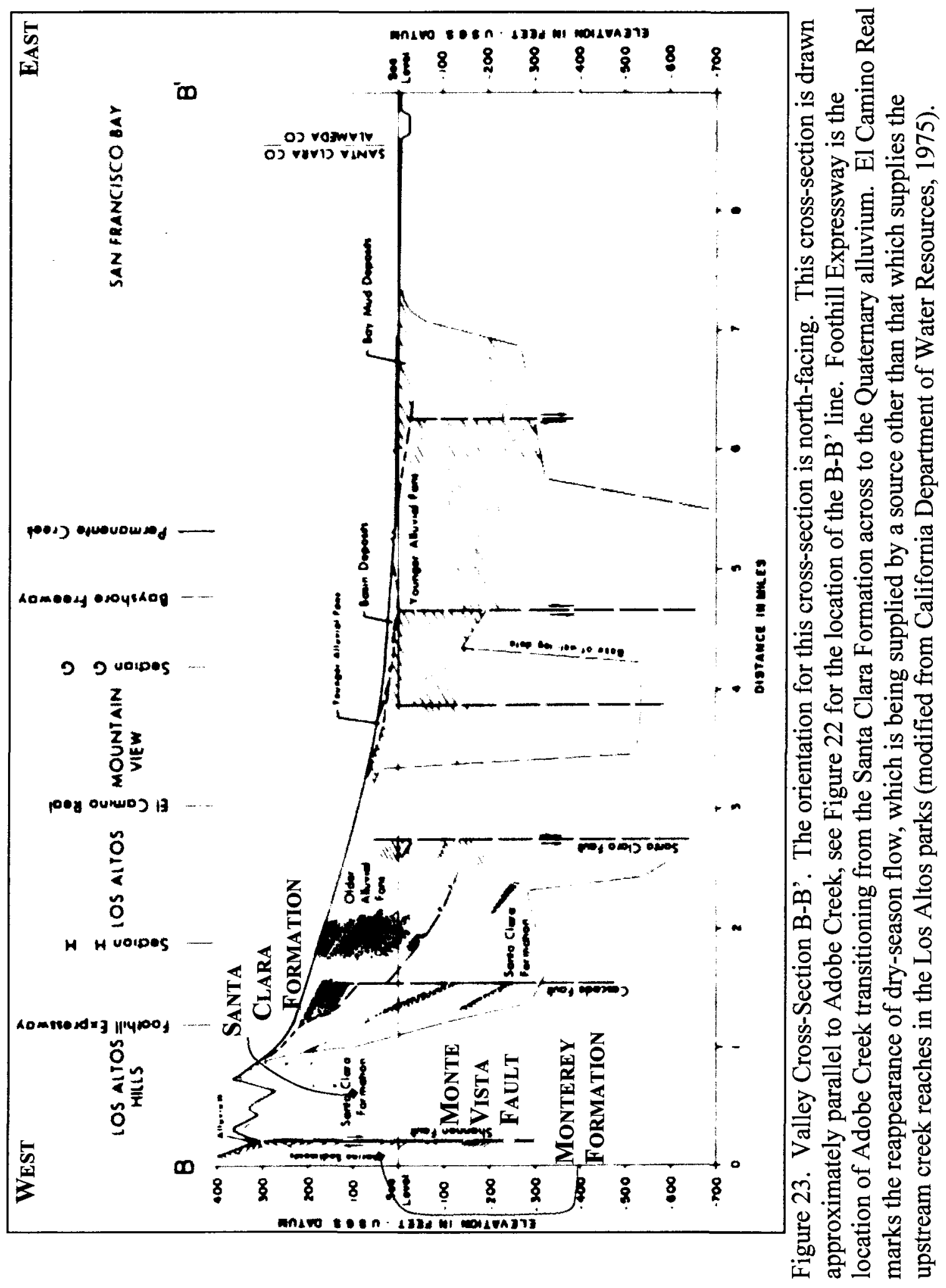




\section{Santa Clara Formation}

Below the Pleistocene and Holocene deposits is the Tertiary Santa Clara Formation (QTsc). This unit is also found along the base of the western foothills where it is faulted unconformably against the Franciscan Complex (Fio and Leighton, 1995). As a continentally-derived sedimentary unit, the Santa Clara Formation is an unconsolidated to moderately lithified conglomerate, clay, silt, and sandstone (California Regional Water Quality Control Board, 2003).

The QTsc is not well-lithified throughout its surface expressions so it is friable and prone to erosion when the native vegetative cover is disturbed or during large rain events when the hillslopes can become unstable. The erodability of this unit contributes to the sediment load and turbidity of the creek (CRWQCB, 2003). Where the QTsc is juxtaposed with the Franciscan Complex, Adobe Creek flows preferentially within the band of the softer QTsc. Along the western margin of the valley, the creek traces a slightly sinuous course as it follows the path of least resistance.

An observation of unknown importance and beyond the scope of this research is the complete lack of Holocene natural levee deposits $(\mathrm{Qhl})$ and Holocene alluvial fan and fluvial deposits (Qhaf) in the lower Adobe Creek Watershed. The lower extents of the other creek valleys, aside from its adjacent Barron and Matadero creeks, are bound by these two units. The absence of these deposits is anomalous for this area, and suggests that Adobe Creek was in an indeterminate state of equilibrium prior to human influence. The possible spectrum of explanations for this situation ranges from the absence of the 
conditions required for the formation of levee deposits to the creek flowing fast and flashy and obliterating the once present deposits.

\section{Geologic Subareas}

Adobe Creek maintains varying flow conditions from the perennial headwaters to the ephemeral flatlands. Early human uncertainty regarding the creek-to-bay continuity was fueled by these conditions and resulted in multiple creek names. According to the historical research in preparation of the Lower Peninsula Watershed Stewardship Plan (LPWSP) it is suggested that there are geomorphic reasons for the two creek names; it describes the creek going dry and then reemerging several miles downstream as a separate channel (SCVWD, 2005). The two different creek names provide insight into the potential for multiple water sources supplying flow to localized sections. Figure 24 shows the recharge zone, which includes the mountain slopes of Los Altos Hills and the alluvial plains of the Town of Los Altos, along the margins of the valley. The transition between the recharge zone and the confined aquifer occurs where the creek flows approximately parallel to Foothill Expressway in Los Altos. Where the creek turns northeast, it crosses the boundary into the Qpaf. On the schematic cross-sectional view of the valley (Figure 25), the letter K marks the location of the boundary between the more consolidated Santa Clara Formation and the more recent overlying alluvial and fluvial deposits. The confined aquifer is in the central portion of the Santa Clara Valley; it is overlain by an impermeable clay layer. 


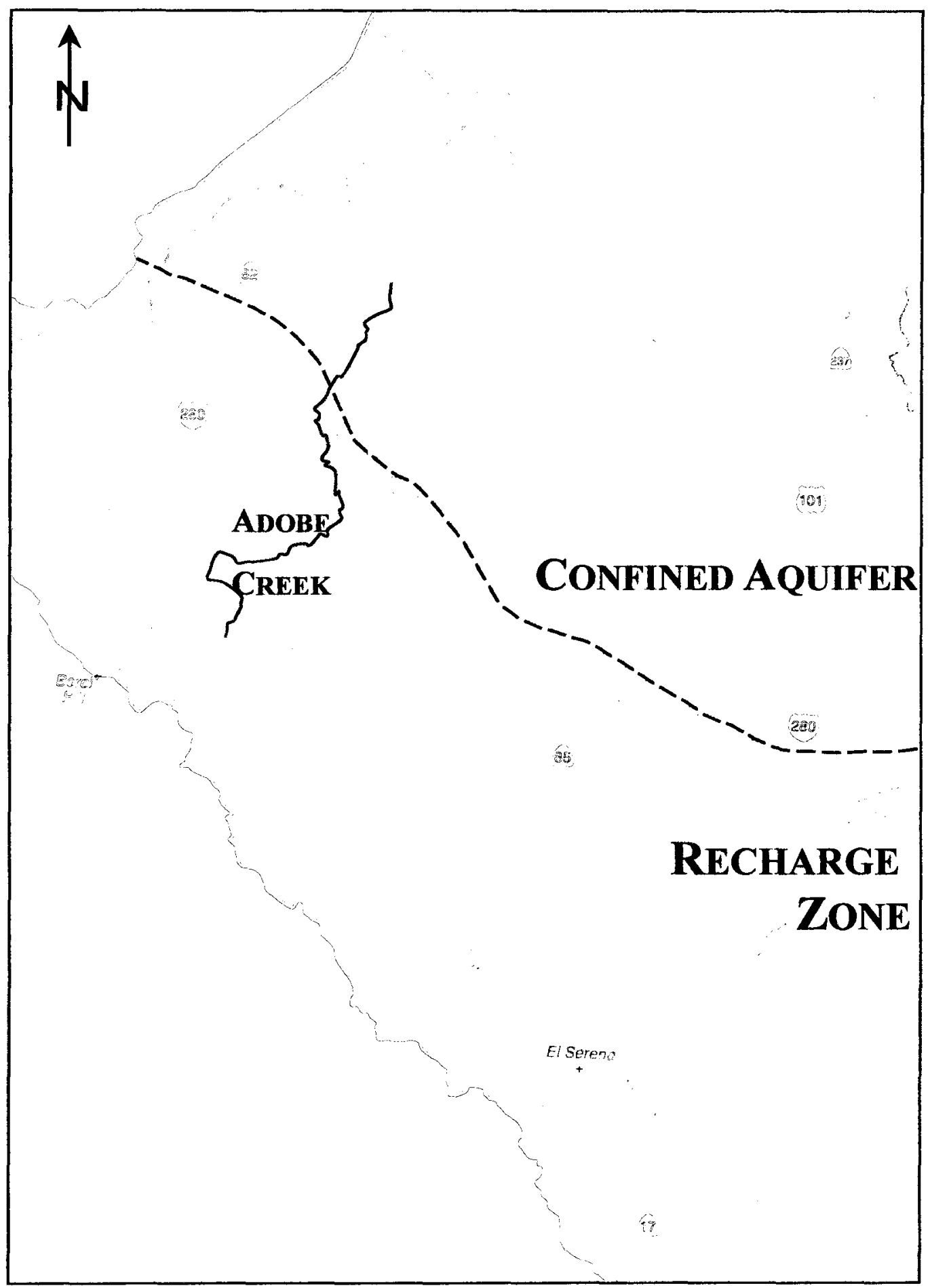

Figure 24. Confined Aquifer and Surface Recharge Zones, Santa Clara Valley. The dashed black line separates the confined aquifer from the recharge zone. This boundary correlates to the Qpaf to the northeast and the QTsc to the southwest; refer to Figure 12 (modified from Givler and Sowers, 2005). 


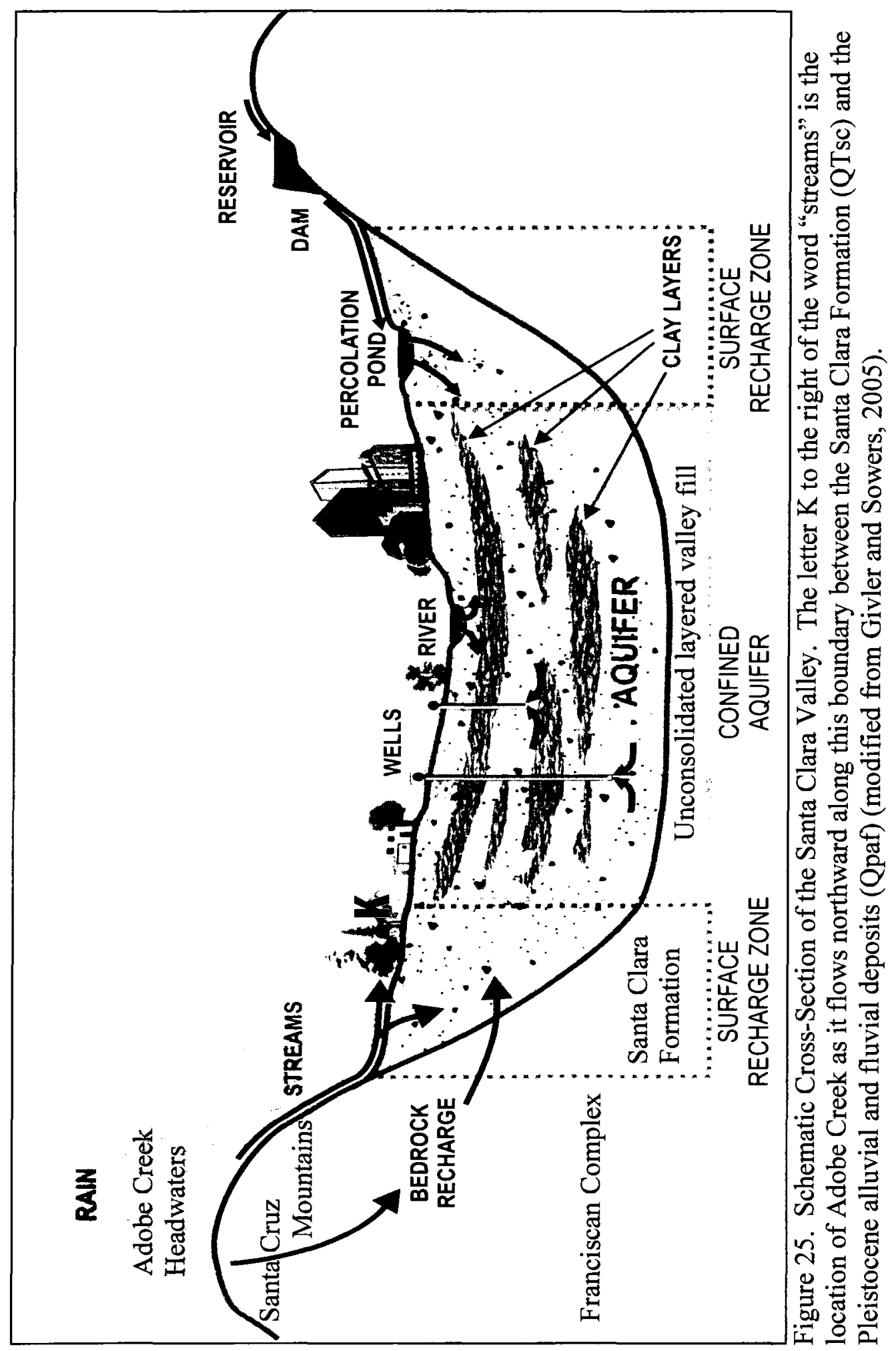


Regional-scale hydrologic subareas as designated by Fio and Leighton (1995) provide an explanation for the early misconception of the existence of two discrete creeks. The subarea geology controls the water movement and distribution. In the Adobe Creek Watershed, the pertinent subareas outlined in Figure 26 are Exposed Bedrock, the Uplands, the West Side Alluvial Apron, and the San José Plain. In the upper watershed, the Exposed Bedrock consists mainly of Franciscan Complex and it is not a significant source of water, since its fractures and joints provide the only voids for water storage. The Franciscan Complex is the basement for the younger alluvium. The Uplands subarea corresponds to the Santa Clara Formation (QTsc). East of the Uplands is the West Side Alluvial Apron which is made up of Qpaf. The eastern side of this geologic subarea corresponds to the boundary of the recharge zone on the west (Figure 24) and the confined aquifer of the San José Plain on the east.

The West Side Alluvial Apron is the subarea vital to groundwater recharge. It is here within the gravels of the Pleistocene alluvial fan deposits (Qpaf) that water percolates and recharges underground aquifers (Fio and Leighton, 1995) (Figure 26). Chemical analyzes of Adobe Creek were published in the 1964 Water Supply Investigation for the North Los Altos Water Company. Water flowed uninterrupted from Adobe Creek Lodge (Figure 7) to Shoup Park (Figure 3) where the water then disappeared underground.

A test using fluorescein dye was conducted to determine if the water disappearing from Shoup Park was supplying the wells downstream. Dye was added to the creek flow at Shoup Park. At the downstream Van Buren Well No. 2 (Figure 27), samples were 


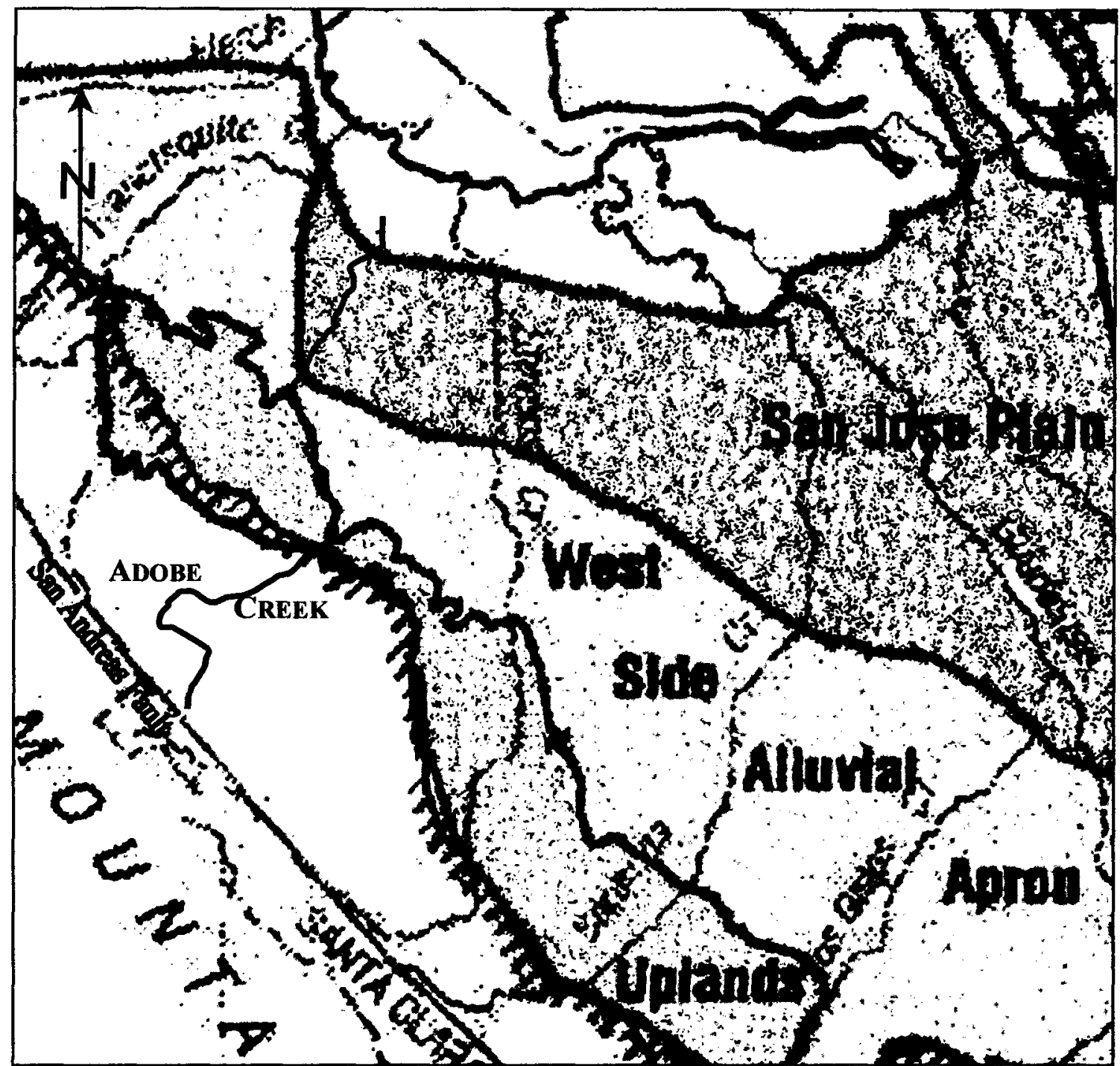

Figure 26. Hydrogeologic Subareas of Western Santa Clara County. The Uplands corresponds to the Santa Clara Formation, the West Side Alluvial Apron corresponds to the Pleistocene alluvial and fluvial deposits. The San José Plain corresponds to the Holocene flood plain deposits and the Holocene basin deposits in the northern-most or lowest part of the watershed. Adobe Creek follows the path of least resistance (modified from Fio and Leighton, 1995). 


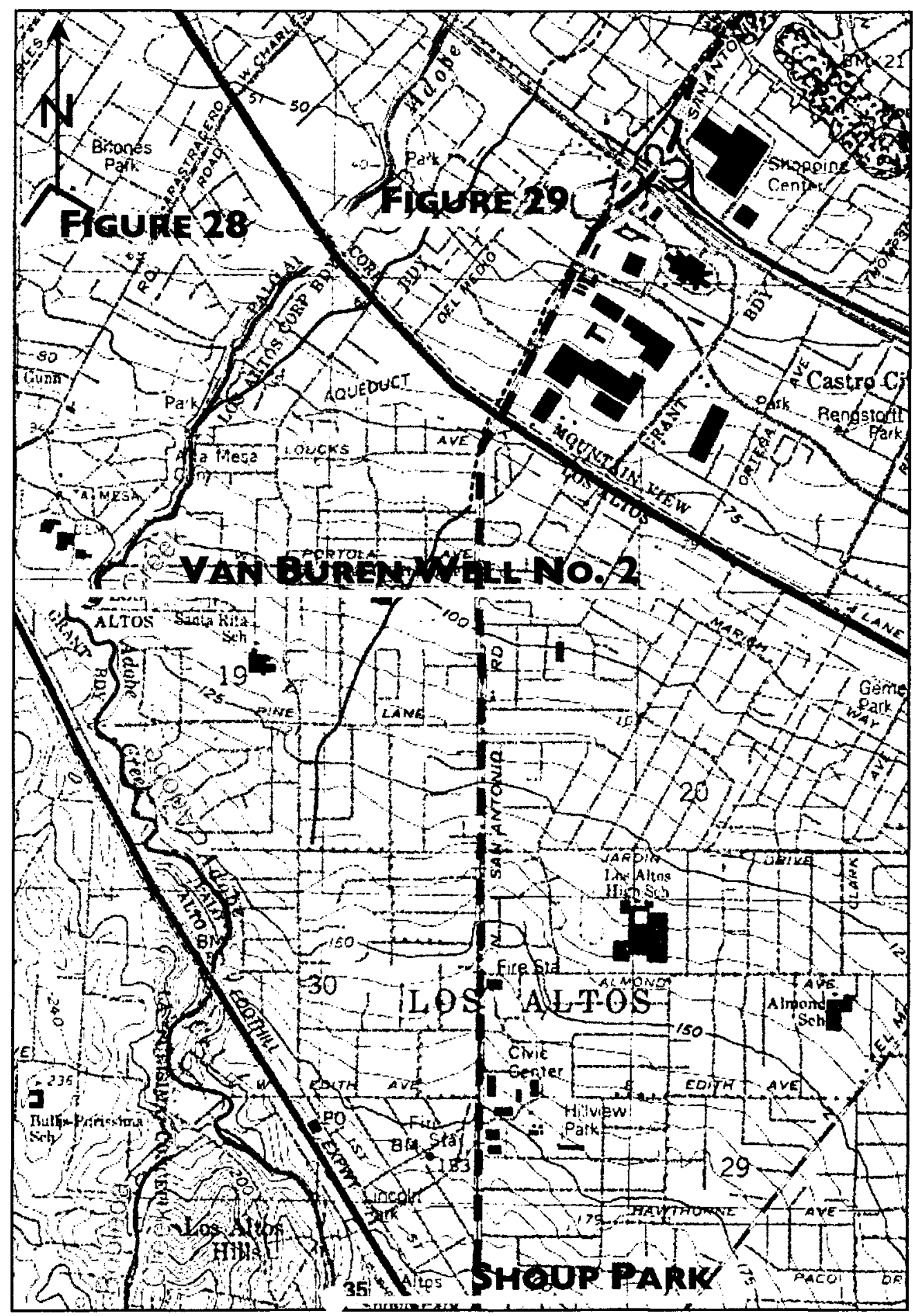

Figure 27. Location of Van Buren Well No. 2 and Shoup Park. Dry season flow disappears into the creek bed by Shoup Park. Dye was introduced to the creek at Shoup Park but was not detected during subsequent tests of the downstream Van Buren Well No. 2 (modified from Sowers, 2004). 
collected for six days but no dye was detected during that time. These results that indicate the creek water at Shoup Park contributes to a separate aquifer other than that which supplies the well downstream. See Figure 27 for the location of Shoup Park with respect to the well tested. Shoup Park is located within the QTsc. The Van Buren Well No. 2 is at the edge of the transition between the QTsc and the Qpaf, the border of the Uplands and the West Side Alluvial Apron. The well test in combination with the sporadic, discontinuous creek flow are related in part to the creek path transitioning from the recharge zone to the confined aquifer of the Santa Clara Valley (Givler and Sowers, 2005).

The lower $3.2 \mathrm{~km}$ ( $2 \mathrm{mi})$ of Adobe Creek consists of a concrete trapezoidal and rectangular channel. The channelized portion begins at El Camino Real (Figure 28) and continues downstream to Highway 101 where the creek transitions to an earthen channel (Figures 8 and 29). North, downstream of El Camino Real, the creek is dry again as it approaches the rectangular channel. At the Alma Street Bridge, the creek receives discharge from various facilities creating a narrow strip of vegetation within the concrete channel. This is where the creek transitions from Qpaf to the Holocene Flood-plain deposits (Qhfp) and Holocene Basin deposits (Qhb) of the confined aquifer of the San José Plain. Here, Adobe Creek is an effluent creek since its initial channelization over one hundred years ago. Its concrete sidewalls with damp seams hint at the possibility of water reemerging from a shallow source. The creek path elevation has been lowered so it is possible that beneath the concrete, the creek is passing through water-bearing layers and thus supplementing dry-season, or non-precipitation-event driven flow. Qhfp 


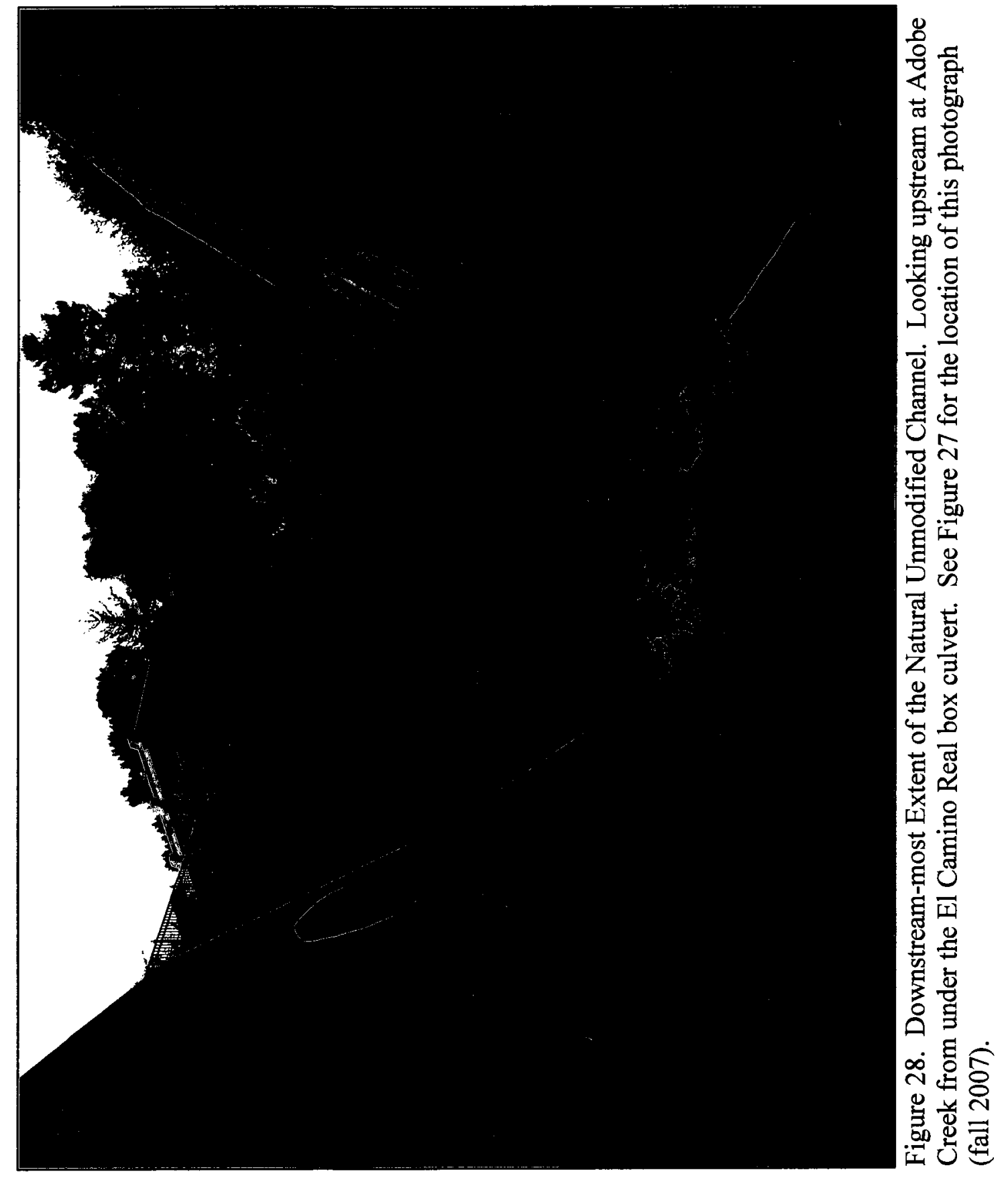




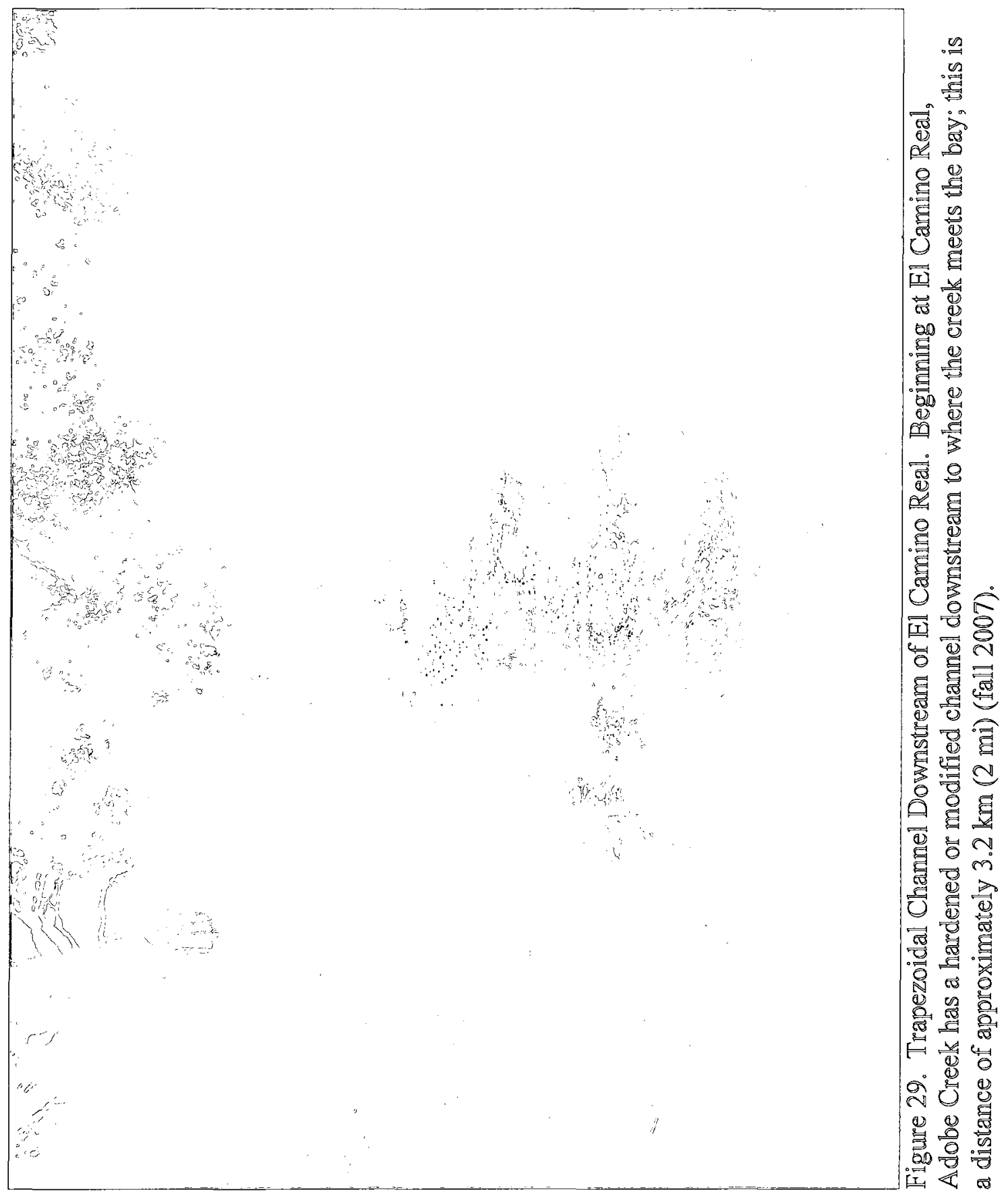


deposits have lenses of coarser material and are more permeable than the Qpaf; these characteristics enable water to travel horizontally along those routes (Fio and Leighton, 1995). On Figure 30, the contour lines are colored with contrasting hues to show the offset between the excavated and lined creek channel elevation and the surrounding bank elevation.

\section{HUMAN INFLUENCE}

\section{A Creek by Many Names}

A brief description of the evolution of the historical nomenclature elucidates the underlying causes and eventual misconceptions regarding creek name variability. Adobe Creek had a myriad of names and a similar number of alignments prior to its present configuration (SCVWD, 2005). Documentation of alternate creek names is in the recent examination of local historical ecology performed by the San Francisco Estuary Institute (SFEI), in cooperation with the Oakland Museum of California, and several Bay Area consulting firms.

Initially, during the first half of the $19^{\text {th }}$ century, the nomenclature of the watercourse distinguished the upper reaches from the lower watershed. The upper watershed, south of El Camino Real, had several ephemeral branches that gradually dissipated prior to reaching the bay. These branches were known as Doby Creek, Arroyo 


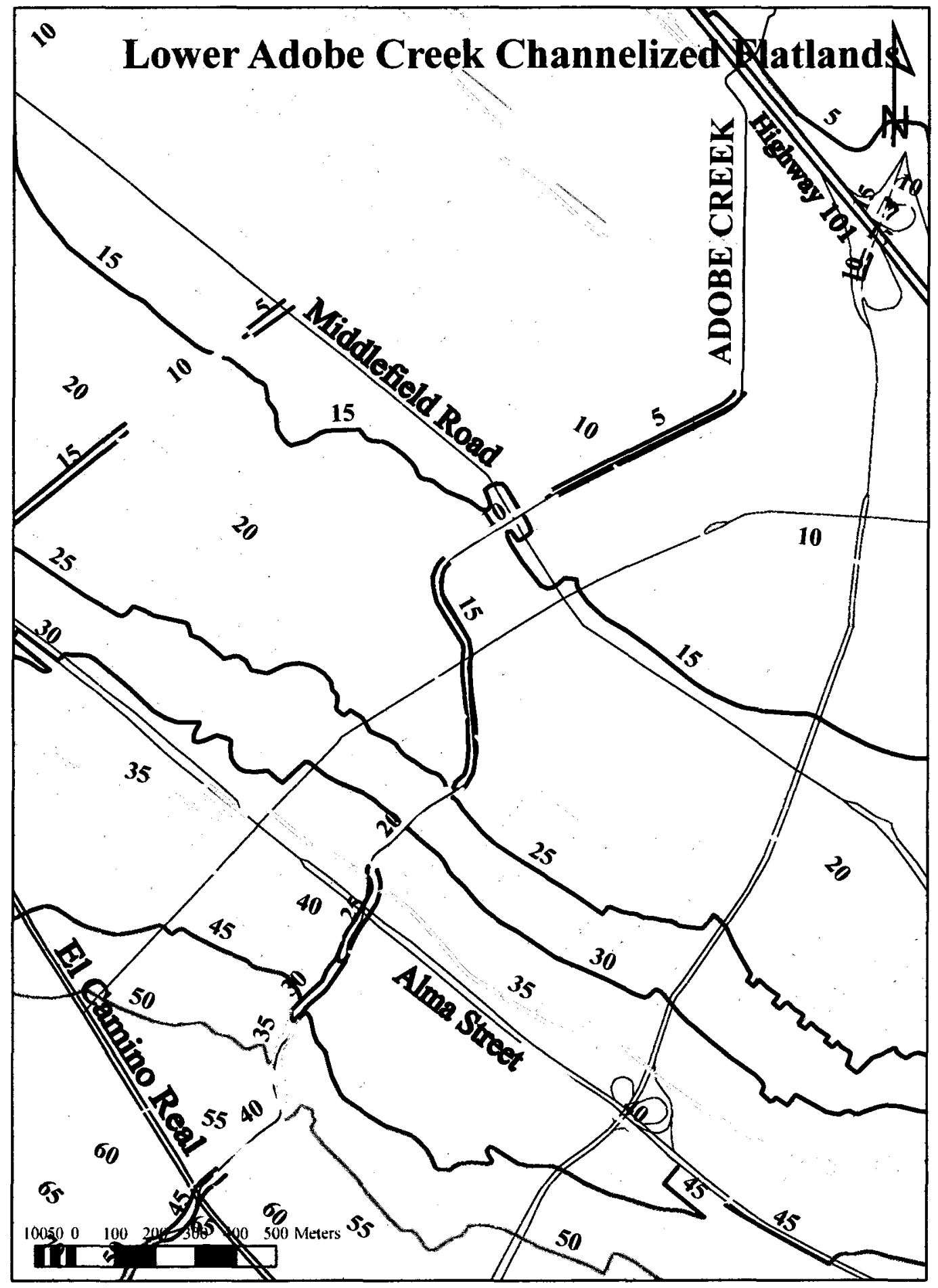

Figure 30. Lower Adobe Creek Channelized Flatlands. The contrasting colors are used for the contour lines to show the distance between the same channel elevation and corresponding banks' elevations. The contour interval is 5 feet (modified from USGS, 1961). 
San Antonio or San Antonio Creek. In the lower watershed, north of El Camino Real, the creek was known as Arroyo de las Yeguas or Yeguas Creek.

Illustrated examples of early map representations of Adobe Creek provide a range of interpretations of creek alignment. On the Allardt map of 1862 (Figure 31), Adobe Creek is shown as a continuous thread with a connection to the marsh, but labeled as two different watercourses, Arroyo San Antonio and Yeguas Creek. On the 1876 Thompson and West map, Adobe Creek (Figure 32) is labeled only as San Antonio Creek. By approximately 1897 , the natural channel and the human-made creek extensions were collectively known as either Adobe or San Antonio Creek as shown on Figure 33.

Present day flow conditions support the perceived need for additional names. For example, Adobe Creek often has dry-season, non-precipitation-event driven flow downstream of 280 at O'Keefe Avenue, however the water disappears by the time it reaches the Los Altos public parks. Through Redwood Grove Nature Preserve and Shoup Park, the intermittent creek is best exemplified. The creek flows and seeps into its bed, and maintains a dry channel through most of the year.

Another modern example of varying flow conditions is located directly upstream of El Camino Real where in-stream vegetation marks the reappearance of dry season flow. Near the end of the dry season, the creek bed through Los Altos and Palo Alto is mostly dry with occasional small pools of water associated with localized urban run-off. Urban run-off is the catchall phrase for the often-inappropriate use of storm drains as sanitary sewers. It consists of effluents that end up in creeks from sources such as overirrigation, sidewalk and car washing, and swimming pool drainage. 


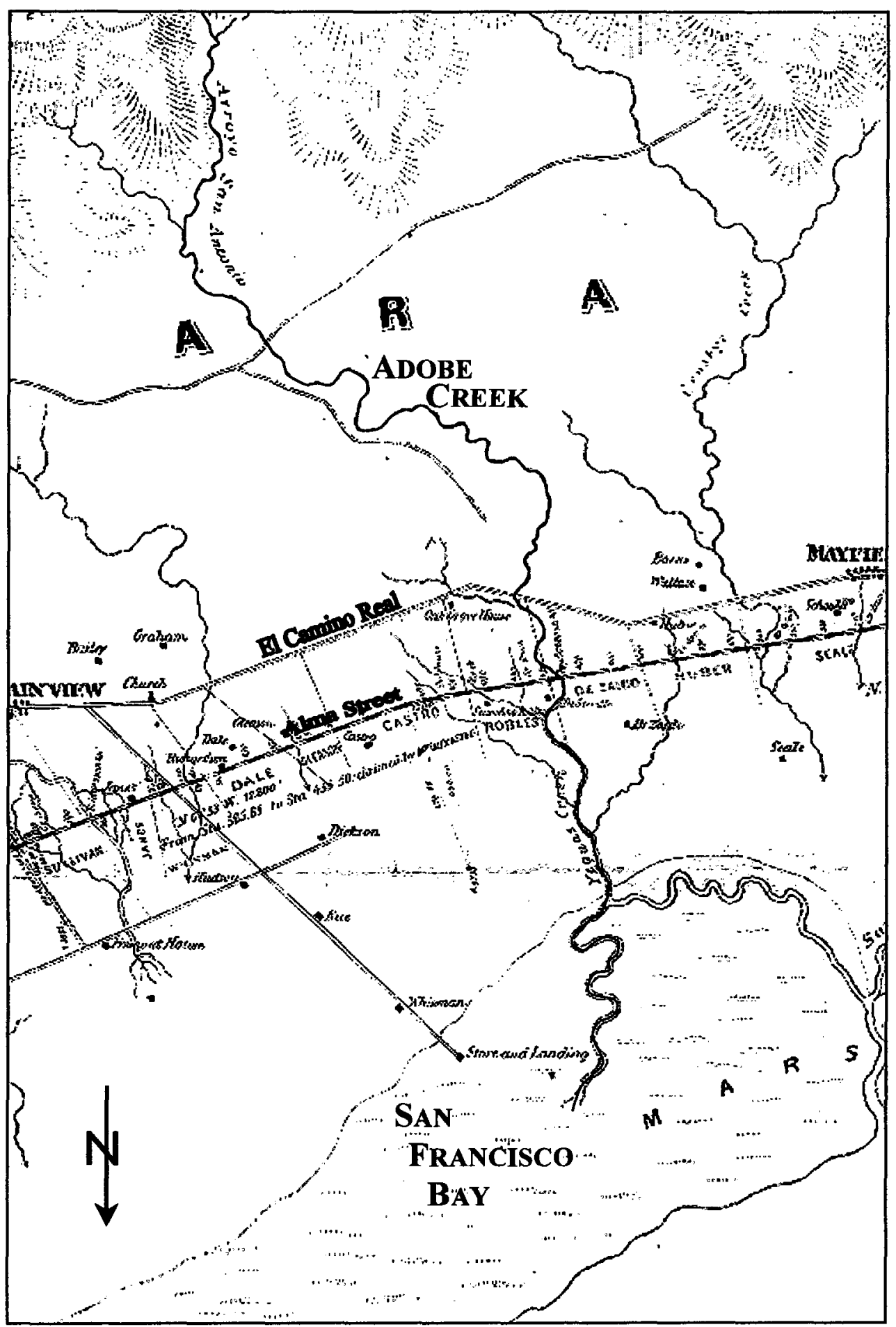

Figure 31. Allardt Map of 1862. Adobe Creek is labeled as two different water bodies, the Upper Watershed south of El Camino Real as Arroyo San Antonio and the Lower Watershed north of El Camino Real as Yeguas Creek (modified from SCVWD, 2005). 


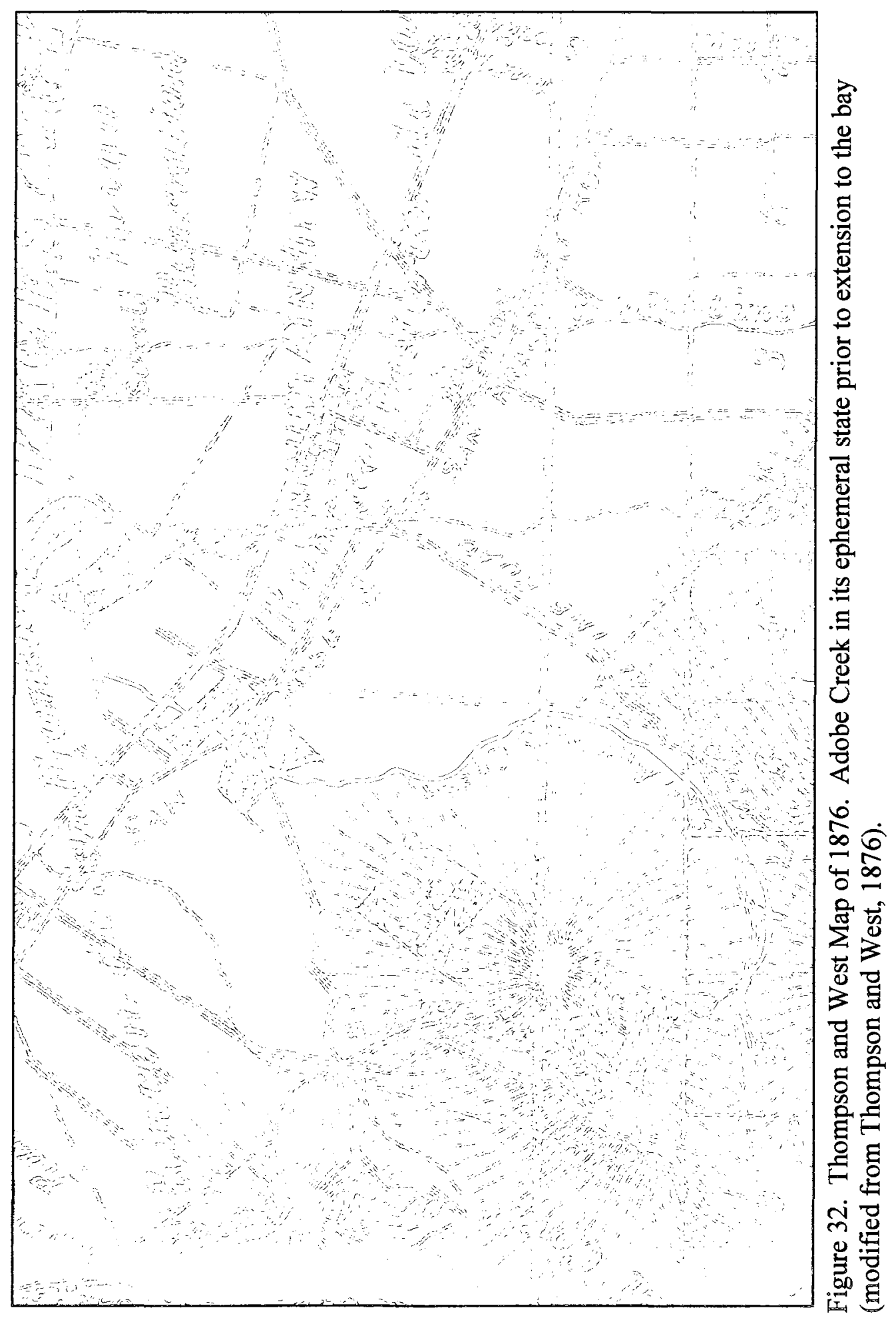




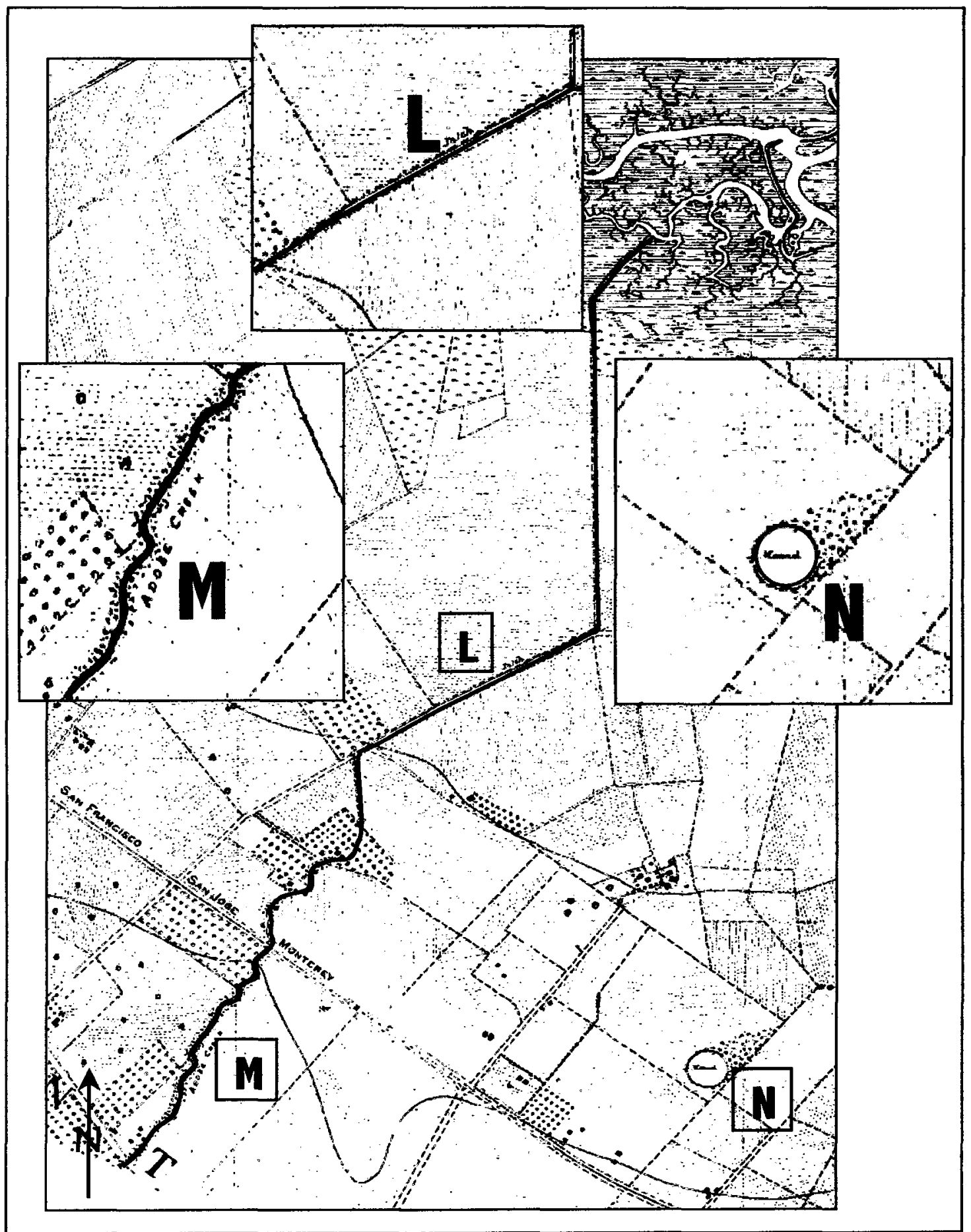

Figure 33. Westdahl Map of 1897. The location of the word "ditch" is shown at the letter L. The letter $M$ shows the orchards encroaching upon the riparian corridor. The sausal or willow grove is shown at the letter N (modified from SCVWD, 2005). 


\section{Early Landuse}

The anthropogenic impacts on Adobe Creek are evident throughout the watershed. The region has been inhabited by humans beginning approximately 6000 years ago (Stanger, 1968). Prior to European arrival, approximately 15 to 20,000 indigenous people occupied the margins of the San Francisco Bay (Grossinger, 2001). The Ohlone people were predominately hunter-gatherers and did not require the creek for irrigation (Cartier et al., 1991).

Upon the arrival of non-native settlers, during the missionization of the valley, landuse changed and water consumption increased. Water was needed for grazing cattle and in the late $19^{\text {th }}$ and early $20^{\text {th }}$ century for intense agriculture. Sausals or willow groves were plowed under to make room for lucrative crops. The intent was to maximize the benefit of the creek and minimize the impacts or concessions required by the creekside neighbors. As agricultural development encroached into the riparian corridor, the need to control the creek path increased. Native vegetation and the unpredictable seasonal creek conditions either occupied or otherwise rendered valuable acreage useless. The resources were molded to fit the requirements of the new inhabitants and as agriculture expanded, Adobe Creek needed to be confined to its own quarters. 


\section{Agricultural Transition}

Prior to the demarcation of subdivisions and the subsequent residential conversion, Adobe Creek was bound by fertile and productive agricultural land (Figure 34). The most plentiful soils in the region around Adobe Creek are the Pleasanton loam and gravelly loam, the Zamora gravelly clay loam and the Sunnyvale clay. All of these soils allowed for deep root penetration, at least $2 \mathrm{~m}(6 \mathrm{ft})$ with the exception of the Sunnyvale clay, which allowed for just moderately deep root penetration, a little over a meter (40 - 60 in) in depth (Gardner et al., 1958). The majority of the soils had slow run off rates, very shallow slopes at 0 to 3 percent and were ideal conditions for high-yield orchards of apricots and prunes (Ableiter et al., 1958). As the conversion of pastureland to agriculture increased, the creek became a resource to harness and exploit. The trees required irrigation and this creek was channelized minimally 25 years earlier than the neighboring creeks (SCVWD, 2005). Table 2 provides a brief overview of the changing industry in San José. This can be used as a proxy for the valley suburbanization and transition to a less agricultural-based economy (City of San José, 2004).

The seemingly inexhaustible supply of near-surface well water added to the overall desirability of the land. The presence of sausals or willow groves near the extent of one of Adobe Creek's ephemeral branches provides confirmation of the high water table (Sowers, 2004). In Figure 35, a solid green line indicates the ephemeral branches. Though the streams were ephemeral in the flatlands, there was ample groundwater to support sausals as indicated on the southeast corner of Figure 35. Another indication of 


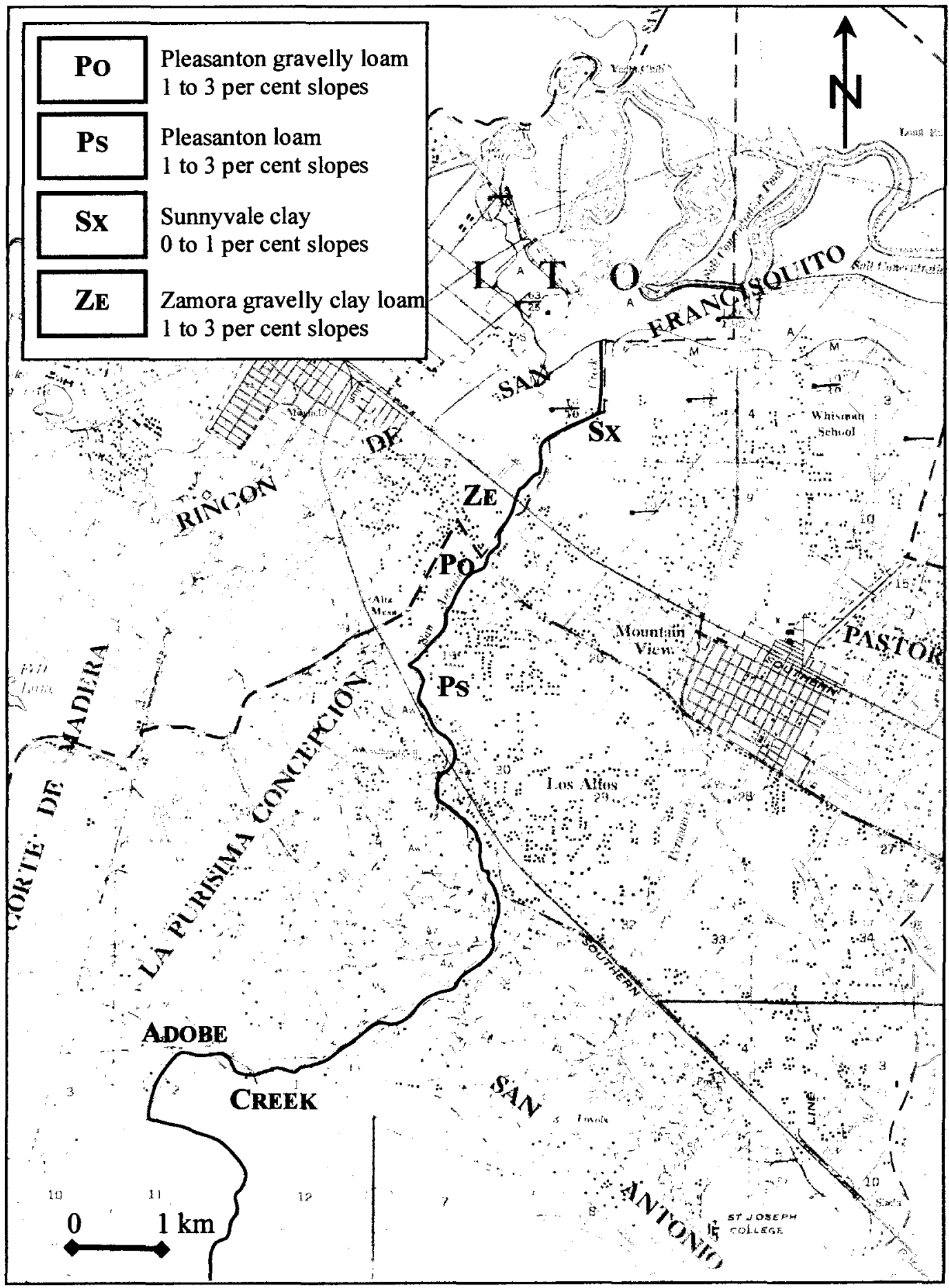

Figure 34. Soils Map of Adobe Creek. The land around Adobe Creek was fertile and put to excellent use for orchards. The most common soils in the region are the Pleasanton gravelly loam (Po), the Pleasanton loam (Ps), Sunnyvale clay (Sx) and the Zamora gravelly clay loam (ZE) (modified from Gardner et al., 1958). 
Table 2. Industry Change in San José. This table is specific to the city of San José but it can be used as a proxy for the Santa Clara Valley showing the shift away from an agricultural based economy.

\begin{tabular}{|c|c|c|c|c|}
\hline & 1950 & 1990 & 2004 & $\begin{array}{c}\text { Per cent } \\
\text { Change } \\
\text { from 1950 } \\
\text { to 2004 }\end{array}$ \\
\hline Manufacturing & 20 & 31 & 20.2 & $1 \%$ \\
\hline $\begin{array}{c}\text { Agriculture and } \\
\text { Mining }\end{array}$ & 15 & 1 & 0.4 & $-97 \%$ \\
\hline Trade & 21 & 20 & 13.5 & $-36 \%$ \\
\hline Service & 17 & 26 & 44.8 & $164 \%$ \\
\hline Construction & 8 & 4 & 4.3 & $-46 \%$ \\
\hline Government & 10 & 11 & 11.1 & $11 \%$ \\
\hline $\begin{array}{c}\text { Transportation and } \\
\text { Public Utilities }\end{array}$ & 4 & 3 & 1.6 & $-60 \%$ \\
\hline $\begin{array}{c}\text { Finance, Insurance } \\
\text { and Real Estate }\end{array}$ & 5 & 4 & 4.1 & $-18 \%$ \\
\hline
\end{tabular}

(Source: San José Planning: General Plan: Fact Sheet Employment (revised 2004)) 


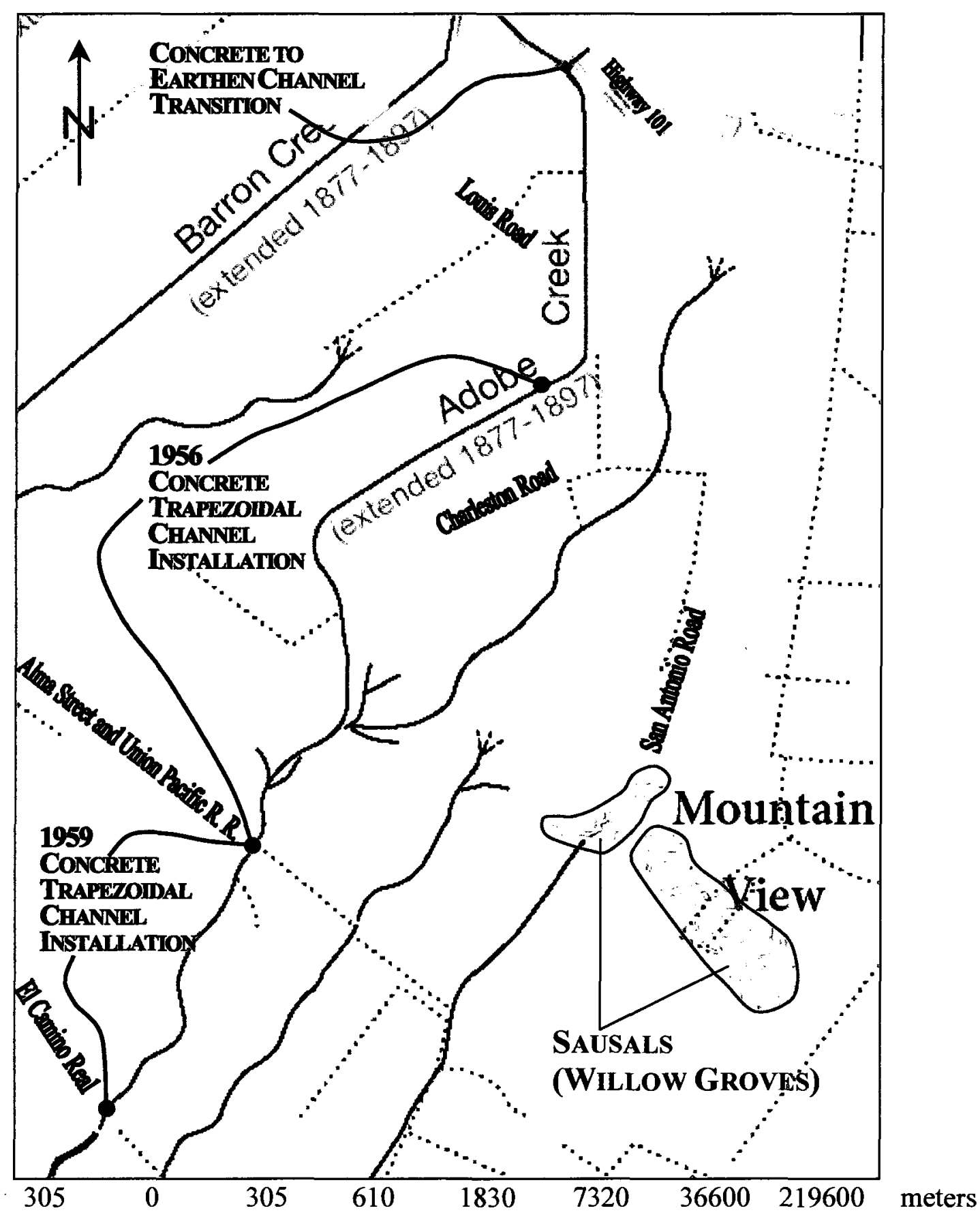

Figure 35. Earthen Transition, Ephemeral Branches, Paleochannels and Sausals.

Former Creek Branches and Sausals in Adobe Creek lower watershed. The portions of the creek in red are the engineered channels, while the green lines represent the paleochannels. The furthest east paleochannel is parallel to San Antonio Road and could be restored during a future road improvement project. The sausals are evidence of a high water table (modified from Grossinger and Askevold, 2005). 
the abundance of water was landscaping of The Alameda. This early road connecting San José to Santa Clara was planted along its entire route with willows harvested from nearby creek banks (Hoover, Rensch, and Rensch, 1958).

\section{Creek Modifications}

Westdahl's 1897 map records the earliest evidence of human intervention and management of Adobe Creek (Figure 33). This map records the modifications made between 1876 and 1895 , when the creek was excavated by humans beginning at its original terminus extending in an earthen ditch from the approximate location of the railroad tracks at Alma Street northward through a sparsely vegetated alluvial plain, and finally out to the bay. This map shows the natural channel labeled "Adobe Creek" and downstream the lower modifications labeled "ditch." This distinction provides insight into the human perception of the importance and functional role of the creek. The end of a thin band of riparian corridor (Figure 33), halfway between the railroad tracks and Charleston Road supports the idea that the creek did not originally or continually reach the bay. The location of Westdahl's transition from 'creek' to 'ditch' (Figure 33) corresponds to the original terminus of Adobe Creek as designated by the period maps in the Thompson and West Atlas of 1876 (Figure 36). The atlas of 1876 provides support that the natural, most dominant path of Adobe Creek dissipated into a bird's foot distributary pattern prior to reaching the bay, south of Charleston Road (Figure 36). 


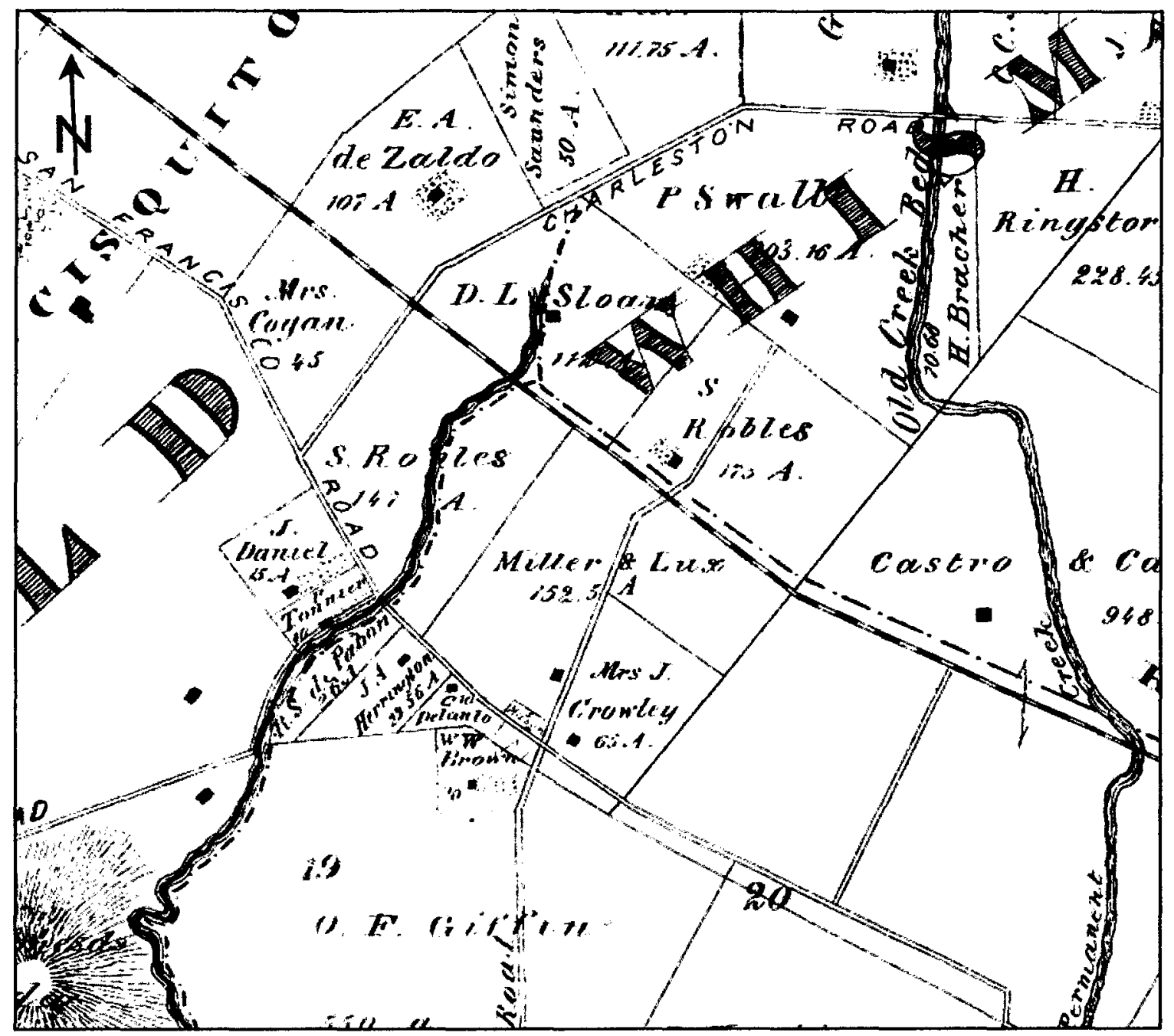

Figure 36. Thompson and West Map of 1876. Adobe Creek in its ephemeral state prior to its extension to the bay (modified from Thompson and West, 1876). 
Evidence supporting the earlier modification of Adobe Creek prior to its neighboring creeks is found in the comparison of the Thompson and West 1876 map (Figure 36) and the Palo Alto 1899 15-minute quadrangle (Figure 37). The 1899 map that shows Adobe Creek already extended to reach the bay by 1895 when the region was originally surveyed. It shows the nearby creeks, Permanente Creek on the east and Matadero and Barron creeks, collectively designated as Madera Creek on the west side of Adobe Creek dissipate prior to reaching the bay.

\section{Riparian Conditions}

On the 1897 Westdahl map (Figure 33), the narrow band of riparian corridor shown by small circles on either side of the creek ends halfway between the railroad tracks and Charleston Road. The riparian corridor was likely similar to the once willowlined region of present day Redwood Grove Nature Preserve, Los Altos. The willows that once occupied the site grew in denser clusters than the current redwoods. According to the childhood recollections of Eugenia Buss, a former resident of the property, the willows died due to blight, probably in the early 1910 's. Her mother replaced the dead trees with redwood saplings (Figure 38) brought from Santa Cruz (Edwards, 2005).

Redwoods modified the riparian conditions from the original willow riparian corridor since their roots are shallow and they extend laterally and intertwine to provide support and stability to surrounding redwoods. Here, the creek appears to maintain a well-connected flood plain, however it lacks some of the typical flood plain 


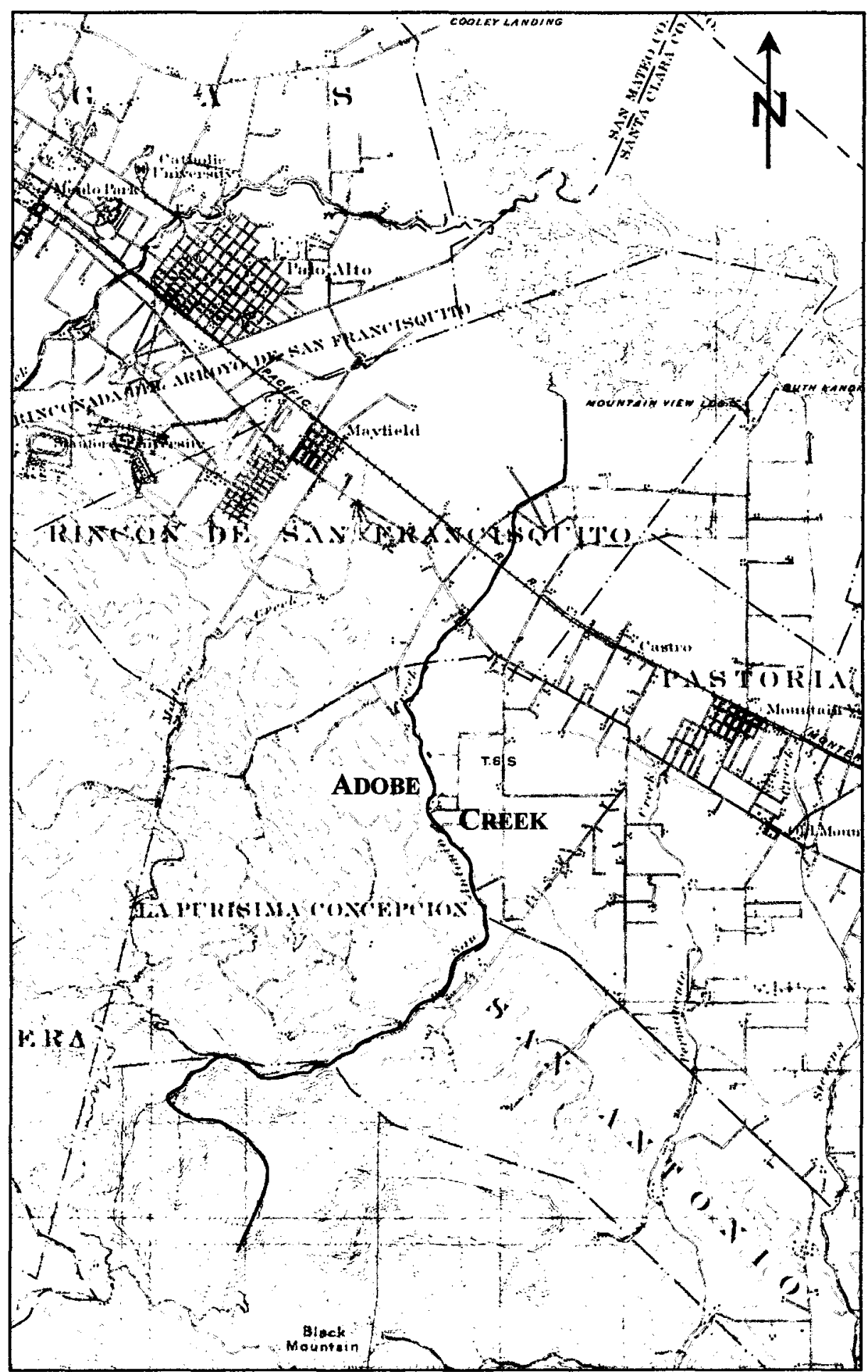

Figure 37. 1899 Palo Alto 30-Minute Quadrangle. This map provides the timing of the extension of Adobe Creek to the bay; it was surveyed in 1895 and published in 1899 (modified from USGS, 1899). 


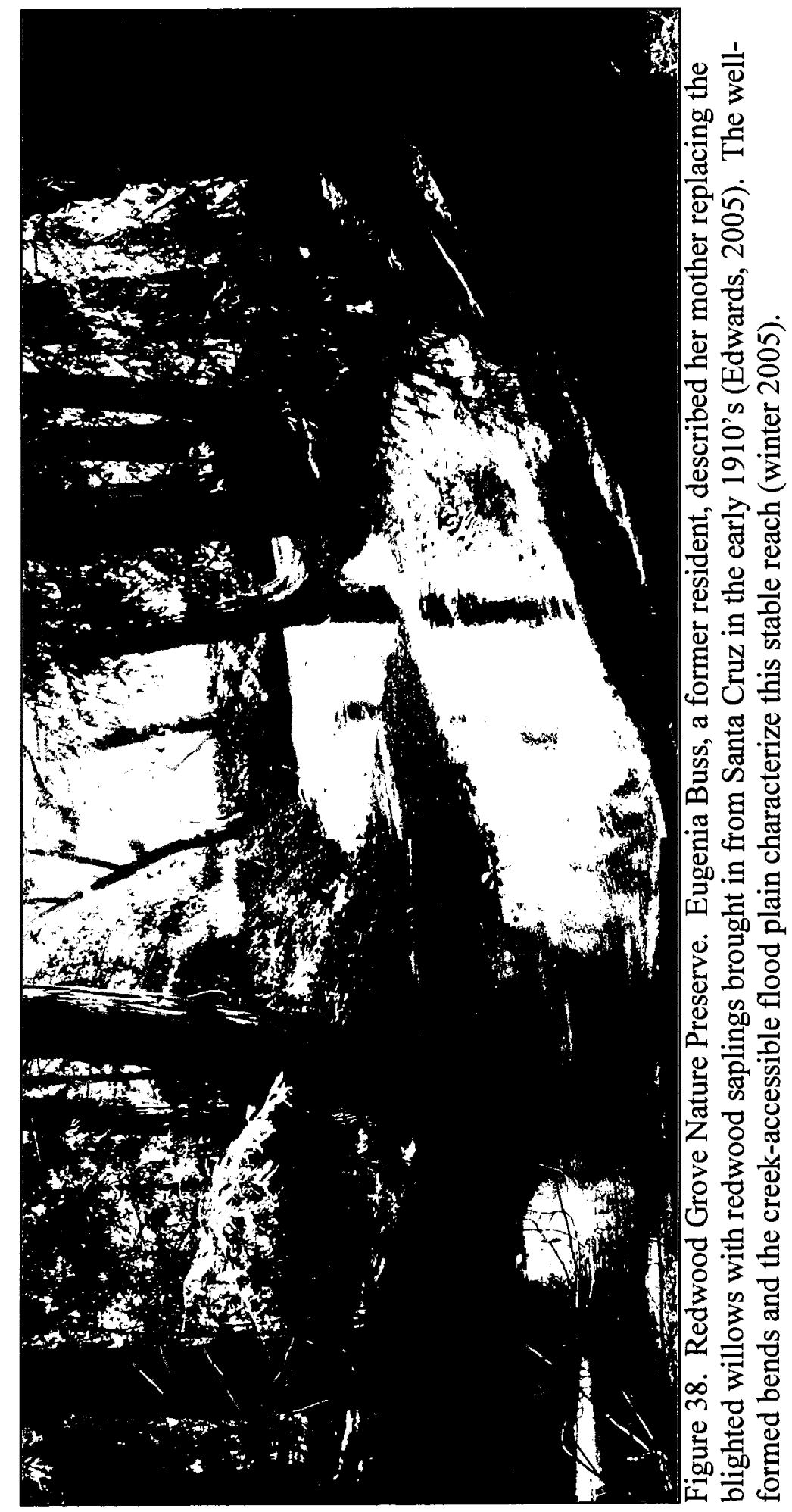


characteristics. The tall trees shaded out more herbaceous flood-tolerant plants and limited the spread of near-water plants in the flood plain.

\section{Segmentation}

The dynamics of the creek were altered as the base level of the creek was lowered when it was forced to meet the bay in an earthen ditch. The new channel increased the longitudinal slope and increased the water velocity through the newly exposed, previously untilled soils making them susceptible to erosion. Where the velocity of the creek had previously slowed and deposition occurred, the erosional power was increased and further exacerbated a situation of disequilibrium. The results were that the creek no longer primarily responded to the influence of nature but instead attempted to correct itself from human-induced change.

Since initial human intervention, the creek has been trying to re-equilibrate by upstream transference or knick point migration. The moving knick point is an expression of the creek's attempt to reach equilibrium (Riley, 1998). The attempt to regrade itself and modify its slope accordingly is thwarted at bridge crossings. It is at these transportation corridors that the creek bed elevation is locked in space and time (Figure 39). The creek is unable to degrade its bed through the bridge crossing, and lateral migration has developed on the downstream side of the bridge. When the creek encounters a narrowing bridge culvert, the water slows and it drops the sediment load on the upstream side and beneath the bridge crossing. The velocity of the sediment-starved water increases through the narrow underpass, then further erodes the already degraded 


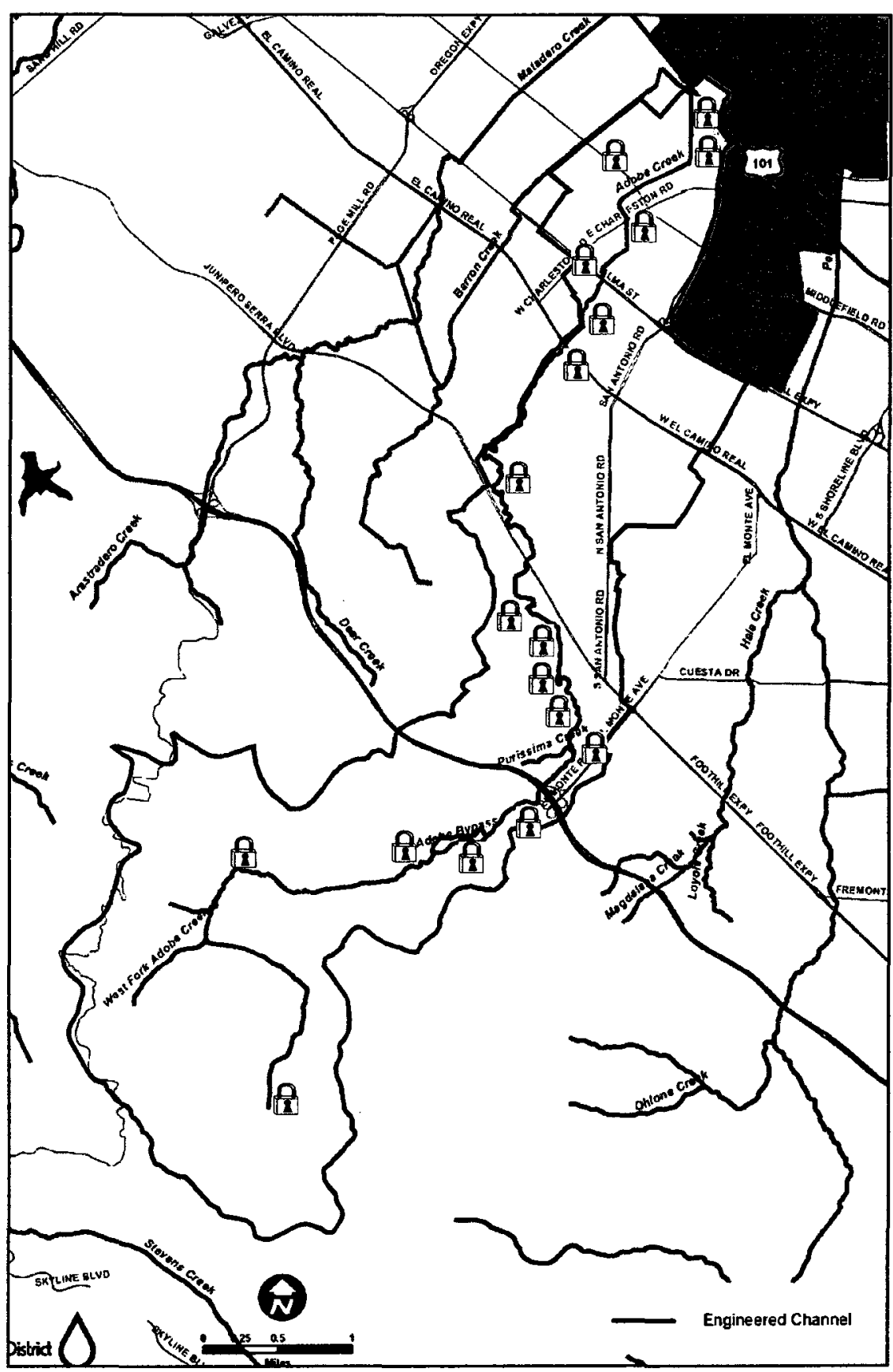

Figure 39. Adobe Creek Locked Segments. Each of the locks represent a section of creek that is fixed in place; either because the channel lining is hardened through limestone precipitation as in the upper watershed or the concrete trapezoidal channels in the lower watershed, downstream of El Camino Real. The mouth of the creek is in the northern portion of the valley (modified from SCVWD, 2005). 
downstream side of the bridge (Figures 40 and 41 ). The creek segments created between transportation corridors are examples of trapped erosion scours or trapped knick points.

Transportation corridors represent only part of the creek segmentation. Realigned and channelized reaches are equally disruptive to the creek's ability to transfer changes through the system. According to the LPWSP, one-third of the creek has a modified, hardened channel bottom. Near the headwaters only the uppermost $3.2 \mathrm{~km} \mathrm{(2} \mathrm{mi)} \mathrm{of}$ Adobe Creek has a natural unmodified bottom; though the naturally occurring chemical hardpan has presented conditions similar to those found in the lower watershed in the concrete channelized sections (SCVWD, 2005).

\section{Suburbanization}

Post-World War II suburbanization brought closure to the era of agricultural dominated landuse (Silva, 2002). The water needs of the valley changed as the population rapidly increased following the end of World War II. In 1940, the population of the Santa Clara Valley was 68,457 . In 1950 , the population was 95,280 and by 1960 a 114 percent increase brought the valley population to 204,196 (ABAG, 1998). While previous agricultural water needs outpaced the rate of natural replenishment, the exponential population growth further stressed the groundwater resources. The groundwater supplies needed to be supplemented as excessive groundwater extraction caused irreparable damage to the capacity of the aquifer.

According to the Santa Clara County Land Use Map of 1970, the region surrounding Adobe Creek Reach 5 had a low population density. The Dwelling Unit per 


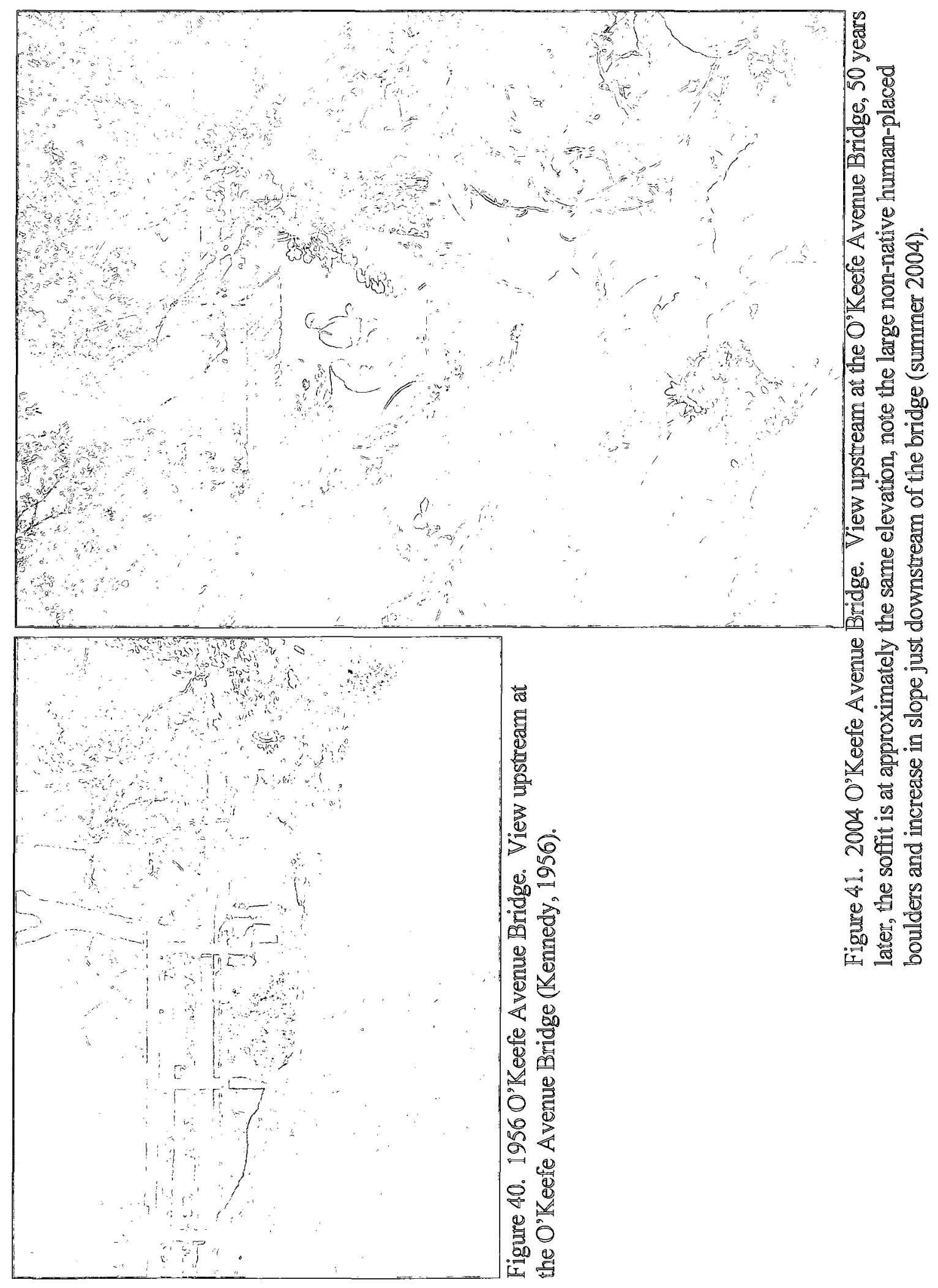


Net Acre (D.U./Net Ac) was grouped in the estimation bin of $0.5-3$ D.U./Net Ac. Today in Los Altos Hills, the value is still only 0.523 D.U./Net Ac (Wikipedia, 2005b); the population density has not increased. The extent of development in the watershed has increased as the population has more than tripled since the town was established in 1956 (Snow, 2003). In neighboring Los Altos, the population density is still comparatively low at 2.3 D.U./Net Ac (Wikipedia, 2005a). The population of Los Altos has had only minor fluctuations since 1960, holding steady for the past 30 years at about 25,000 (Los Altos Chamber of Commerce, 2004). Figure 42 shows the residential developments near Edith Park just upstream of Reach 5. The aerial photograph was taken in 1972. In comparison to Figure 4, the increased development has hemmed the creek into a narrower corridor.

\section{Subsidence}

Groundwater provided interstitial support, and as water was removed the voids collapsed under the overburden, subsidence began to occur. In the Los Altos region, subsidence ranged from $0.15 \mathrm{~m}(0.5 \mathrm{ft})$ at Adobe Creek near Foothill Expressway at the western edge of the confined aquifer to approximately $0.9 \mathrm{~m}(3 \mathrm{ft})$ on the north side of Los Altos, west of El Camino Real (SCVWD, 2004b) (Figure 43). In fall of 1931, because of the financial depression, voters rejected legislation to build reservoirs (McArthur, 1981). In 1932, the District applied for funding from the Public Works Administration. This grant would have provided 30 percent of the funds needed for reservoir construction (Figure 44). By 1934, the depth to water levels had reached an all 


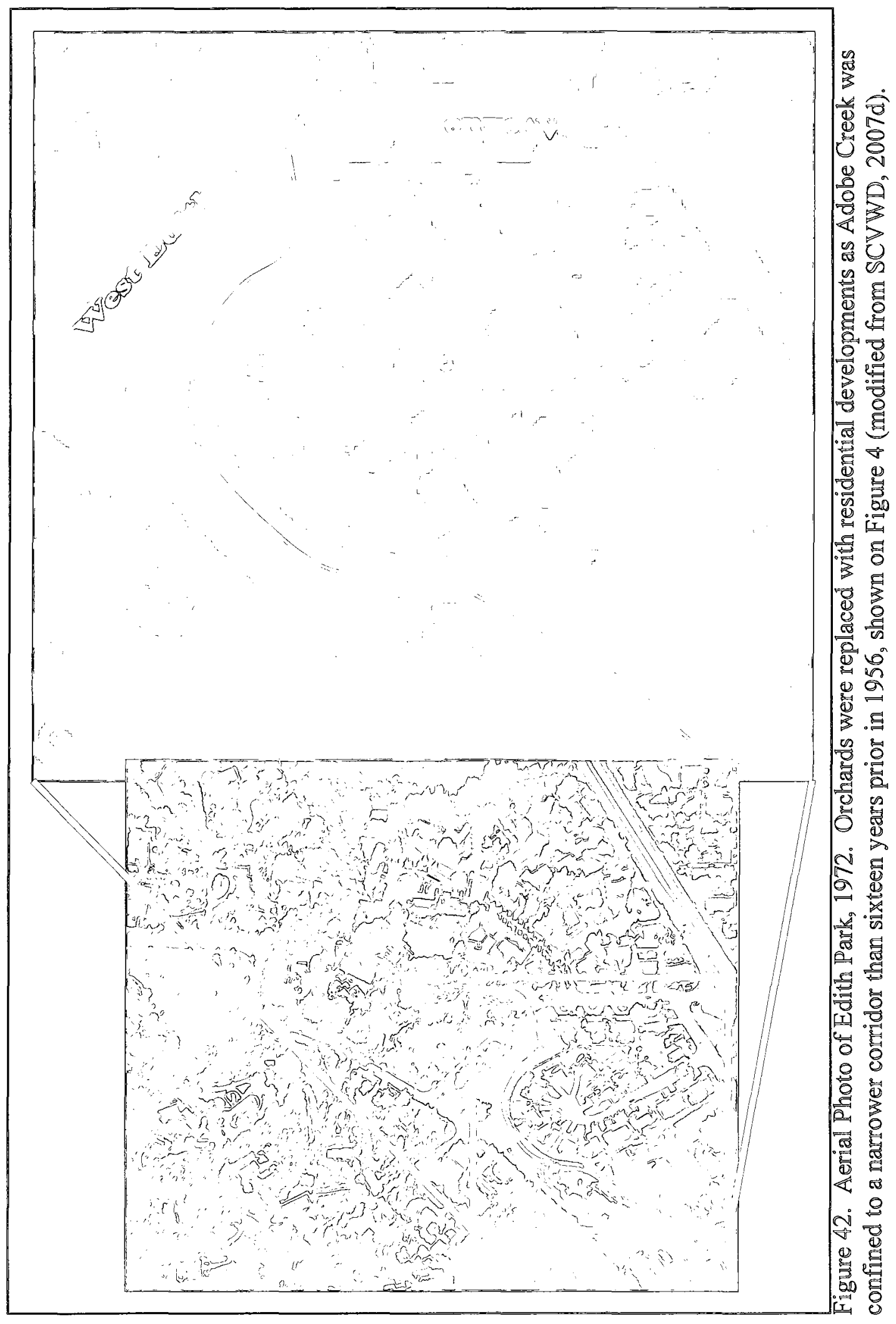




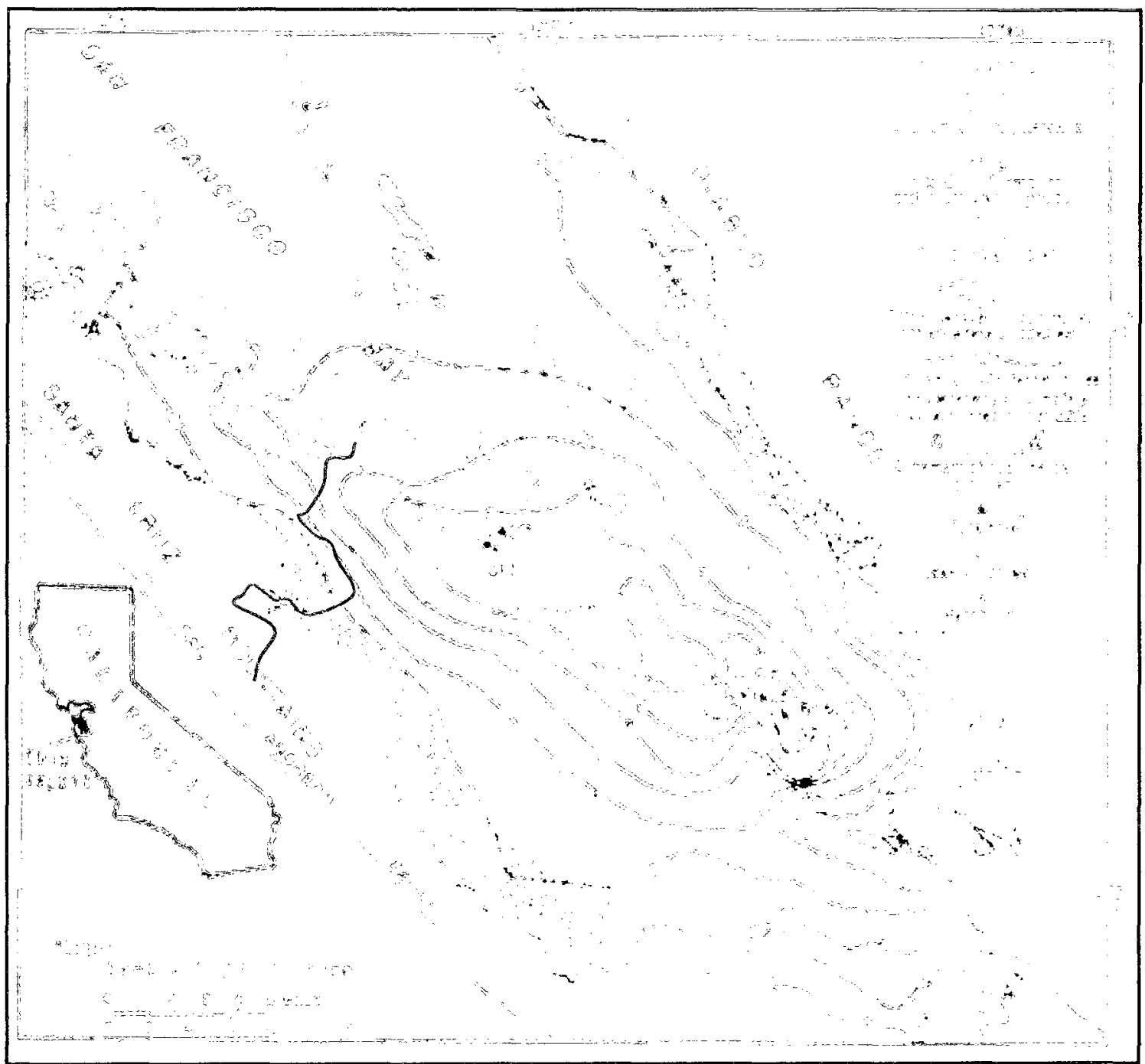

Figure 43. Subsidence Map of Santa Clara Valley. Land subsidence in the Santa Clara Valley between 1934 and 1967. The approximate location of Adobe Creek is marked in blue (Poland, 1984). 


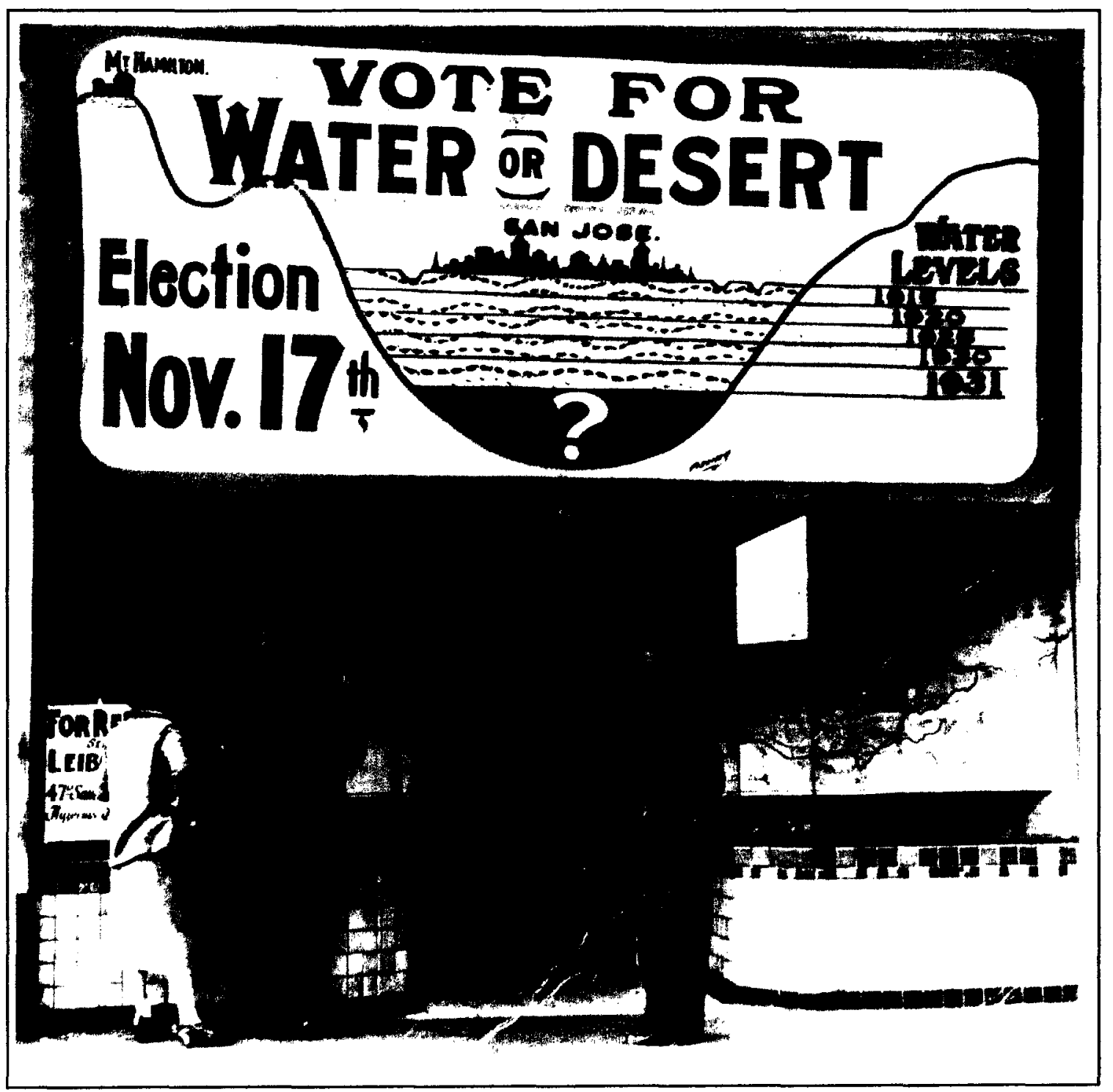

Figure 44. 1931 Election Poster. This poster was designed to promote passage of legislation to build reservoirs. The funding was not approved by voters during the 1931 election; it was tabled until the spring of 1934 when the groundwater levels had hit historic depths. Voters approved the construction of six reservoirs: Almaden, Guadalupe, Calero, Coyote, Stevens Creek and Vasona (McArthur, 1981). 
time low of $43 \mathrm{~m}(140 \mathrm{ft})$ (Figure 45). This was the lowest level of groundwater or the greatest pumping distance the valley had experienced. In the spring of 1934, voters passed bond legislation to build six reservoirs to contain rainfall and runoff. Almaden, Guadalupe, Calero, Stevens Creek and Vasona Reservoirs were all completed in 1935. Coyote was finished in 1936 after modifications were made to account for the proximity to the Calaveras fault system (SCVWD, 2002a). These reservoirs help to regulate the rates of runoff and instream percolation. As the population continued to grow, the demand for water increased. In the late 1940's voters passed measures to build Anderson and Lexington reservoirs; the construction was completed in 1950 and 1952, respectively (SCVWD, 2002a). Additional assistance came in 1965 when the valley began to receive water from the South Bay Aqueduct (SCVWD, 2001). By 1969, the subsidence had all but ceased as the District monitored groundwater levels; balancing extraction with the importation of water and the percolation of existing surface water in surface recharge ponds.

\section{0's Flood Control}

Adobe Creek channel modifications came in response to the Christmas Week Floods of 1955 (Figure 4). The District's 1956 Capital Improvement Project report addressed flood protection issues along Adobe Creek through the populated regions of the watershed (Figure 30). A plan was developed to construct a concrete trapezoidal channel from Alma Street to $335 \mathrm{~m}$ (1100 ft) upstream of West Edith Avenue. The plan 


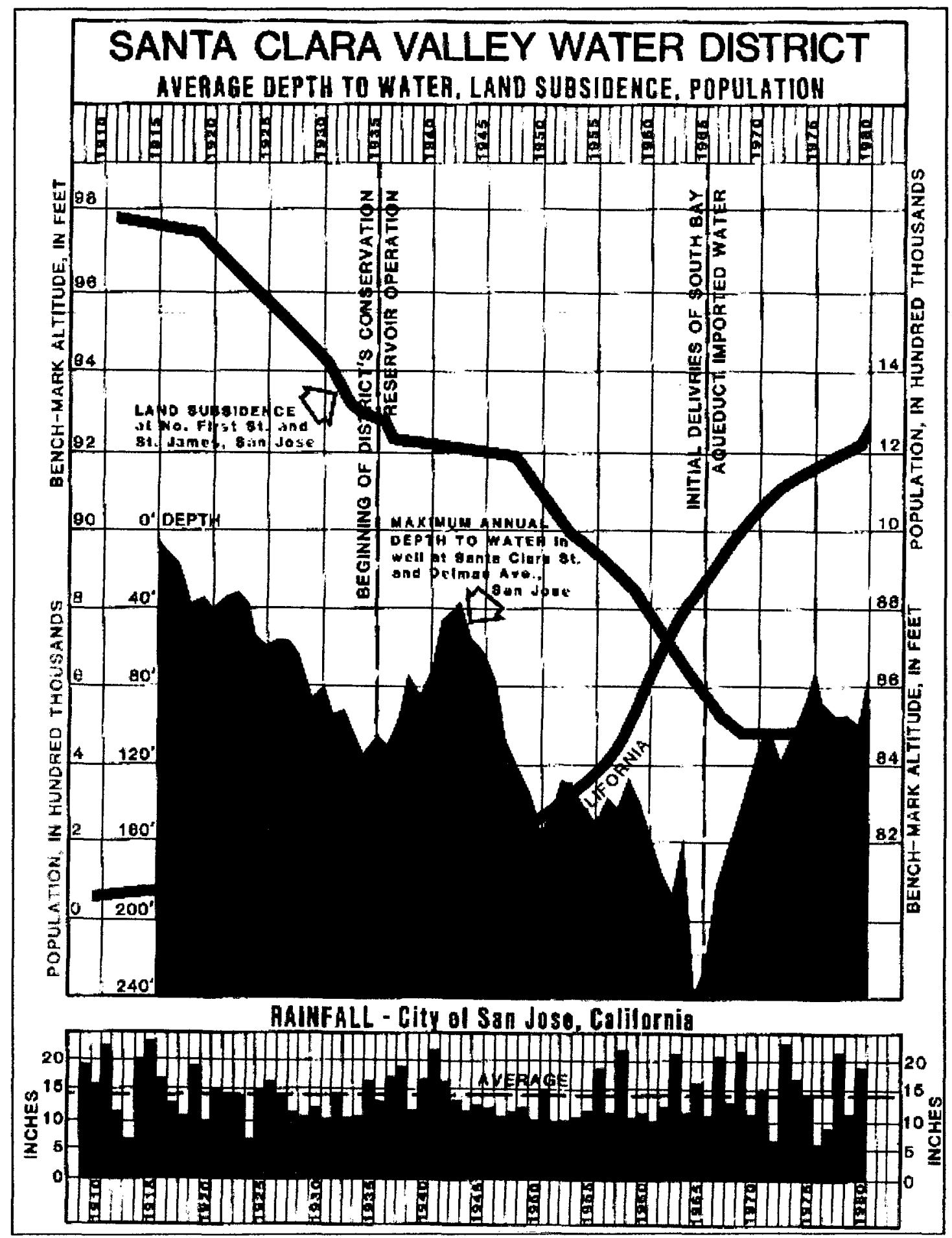

Figure 45. Depth to Groundwater, Population and Subsidence Graph. The graph shows the increased depth to reach water in blue, and the Santa Clara Valley population growth as an inverse ratio to the land subsidence (McArthur, 1981). 
included a conversion of the channel upstream of West Edith Avenue to El Monte Road into an excavated earthen ditch (SCVWD, 1999).

In 1956, construction began on the installation of a concrete trapezoidal channel from Louis Road to Alma Street shown on Figure 30. In 1959, the last segment of concrete channel upstream to El Camino Real was installed. Public opposition halted any further upstream construction and the remainder of the channelization plan was abandoned (SCVWD, 1999). The remaining sections of creek from El Camino Real in Palo Alto through Los Altos into Los Altos Hills to El Monte Road were left as is.

Southwest of Foothill College are the remnants of the once posh resort, the Pink Horse Ranch (Figure 7). Forty-two acres of this area were purchased by Wendel Roscoe where, during the floods of the 1950's, his property was inundated with $0.6 \mathrm{~m} \mathrm{(2 \textrm {ft } ) \text { of }}$ water. Roscoe installed a floodgate for discharge control and then a series of diversion dams to route the creek through his property (Hill, 2001).

\section{0's Flood Control}

In 1975, the District conducted a study of Adobe Creek from El Camino Real upstream to the headwaters. After the publication and subsequent public meetings it was decided that future erosion problems on Adobe Creek would be dealt with on an "as needed" basis. An additional outcome of this study was the installation of a $2.4 \mathrm{~m}(8 \mathrm{ft})$ diversion above the Roscoe property to reroute the creek northward toward Foothill

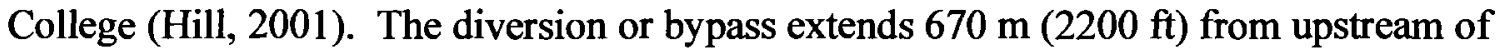


Tepa Way (Santa Clara Basin Watershed Management Initiative, 2003) to downstream near the intersection of Moody Road and El Monte Road on the Foothill College campus (SCVWD, 1999) (Figure 46). The diversion has a flashboard system so only high flows go into the bypass. Upstream of and through Foothill College much of the creek channel has been channelized, lined with concrete and realigned. Figures 47 and 48 show typical views of the creek through the college.

\section{0's Flood Control}

In 1985, the original 1931 bridge (Kennedy, 1956) at West Edith Avenue (Figure 49) was replaced with a bridge crossing capable of containing and withstanding a 100year event. The bridge construction was funded in part by a federal grant, and the rest came from Los Altos, the Town of Los Altos Hills and the District. The grant stipulated the bridge must be replaced in the exact location so modifications to the alignment were prohibited (Wilson, 2004).

\section{FIELD RESEARCH}

\section{Survey}

During the first week of August 2004, a reconnaissance survey of the upper watershed was completed. Representative reaches were chosen for the installation of 


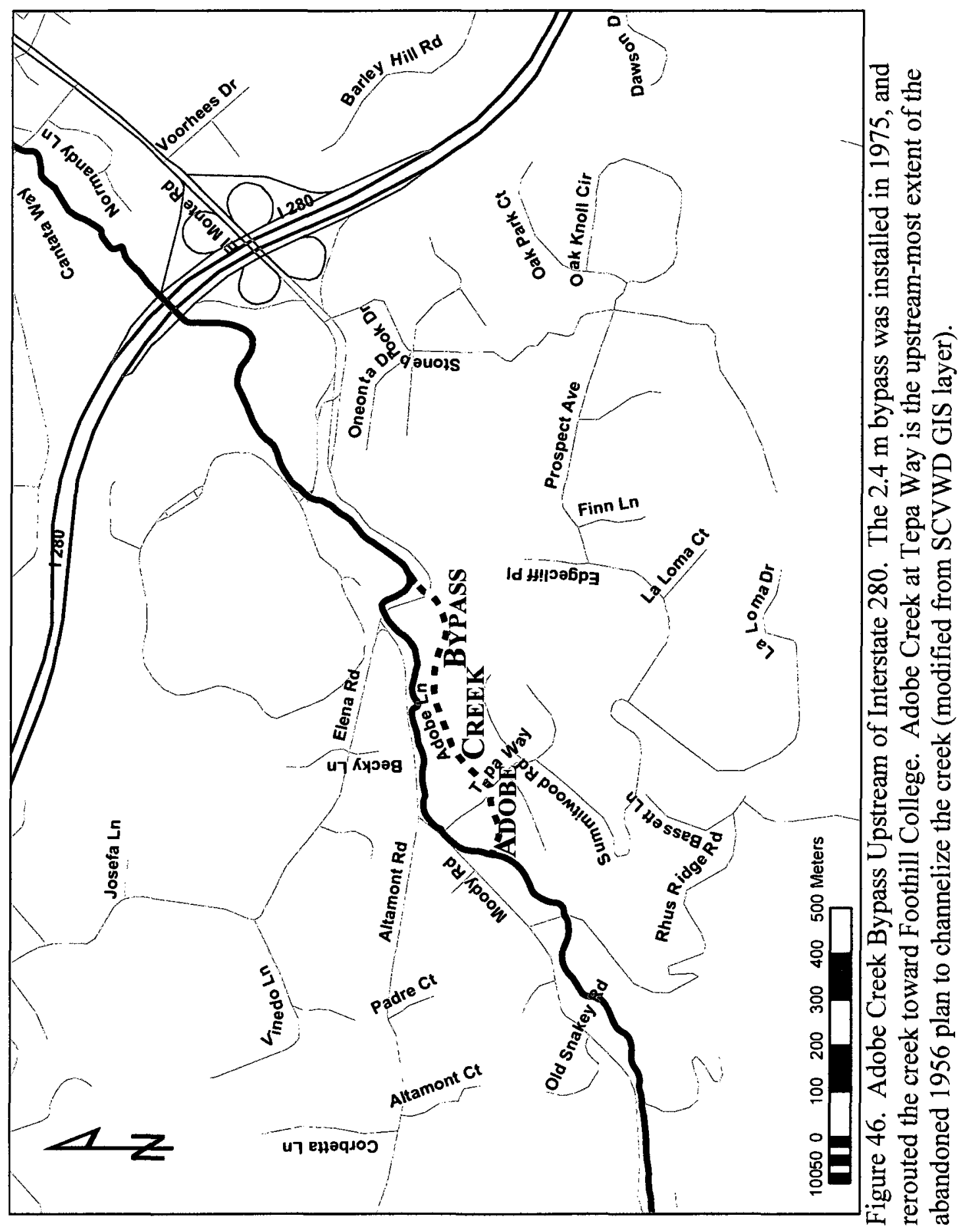




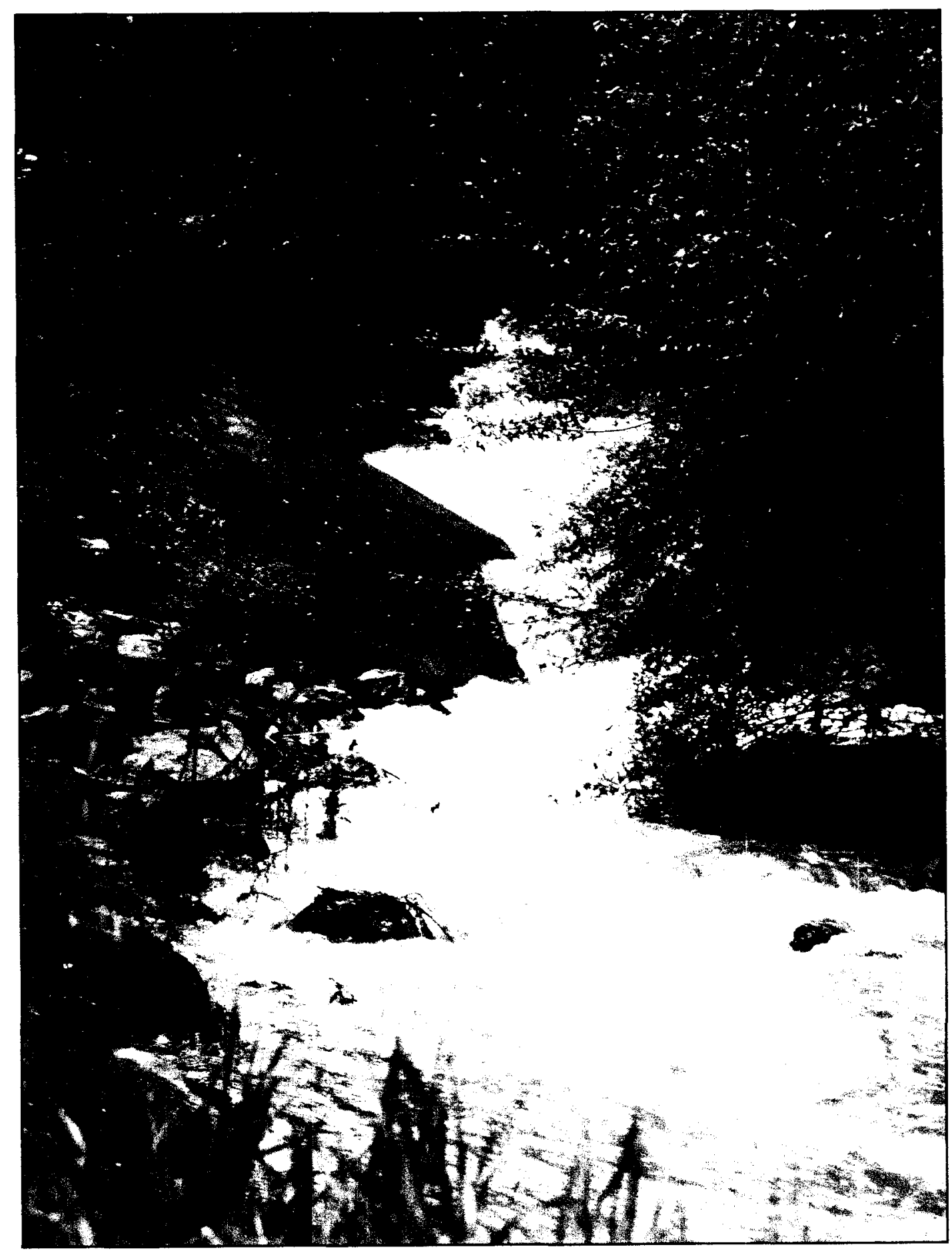

Figure 47. Typical Channelized Section through Foothill College. This photo was taken during the April showers of 2006. The channel is made of concrete trapezoidal sections with some boulder riprap. Concrete steps are throughout the reach on the campus. 


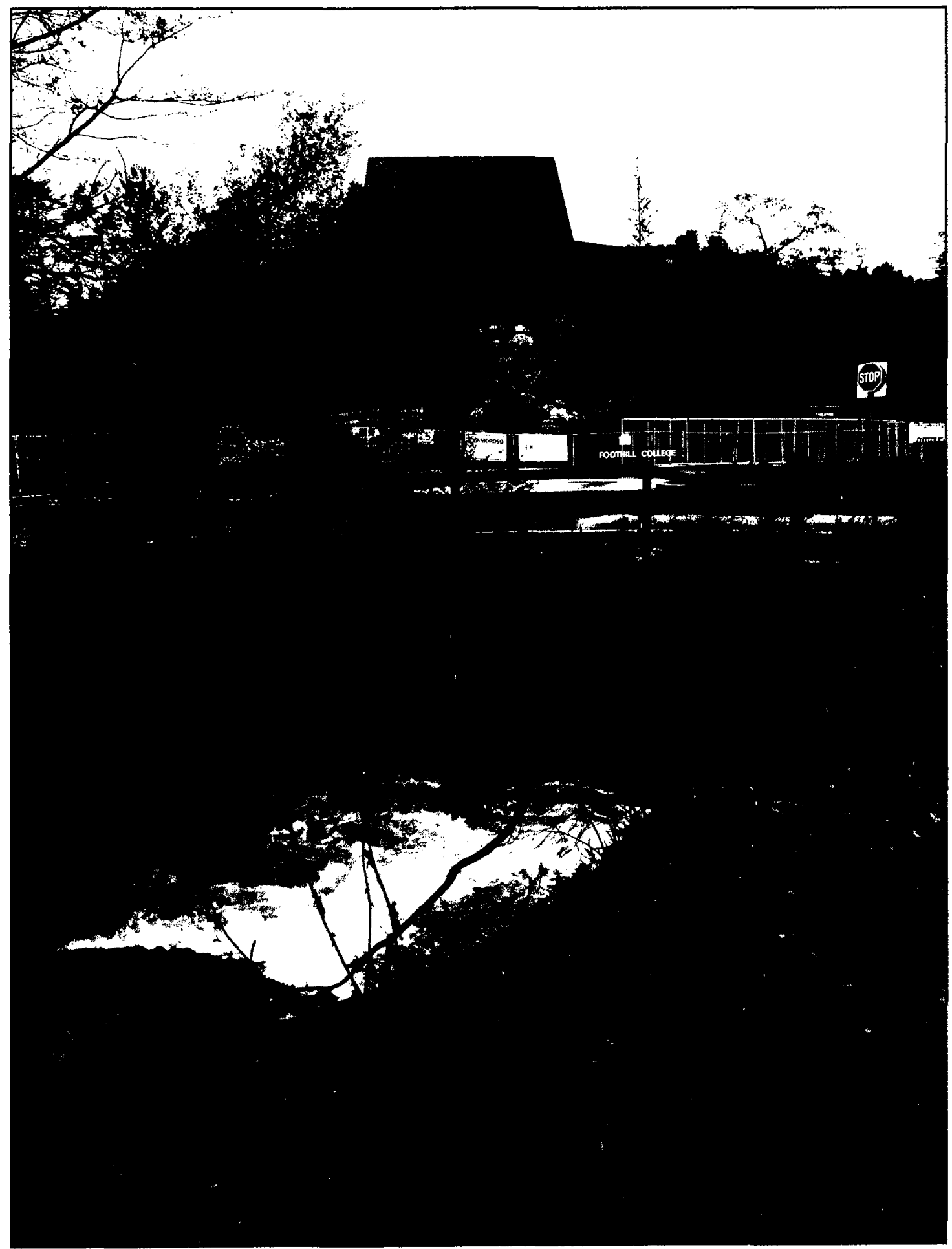

Figure 48. Typical Bridge Crossing in Foothill College. Located in the upper watershed upstream of Interstate 280, this photograph exemplifies the discontinuous riparian corridor, the segmentation and the resulting locked creek path (spring 2006). 


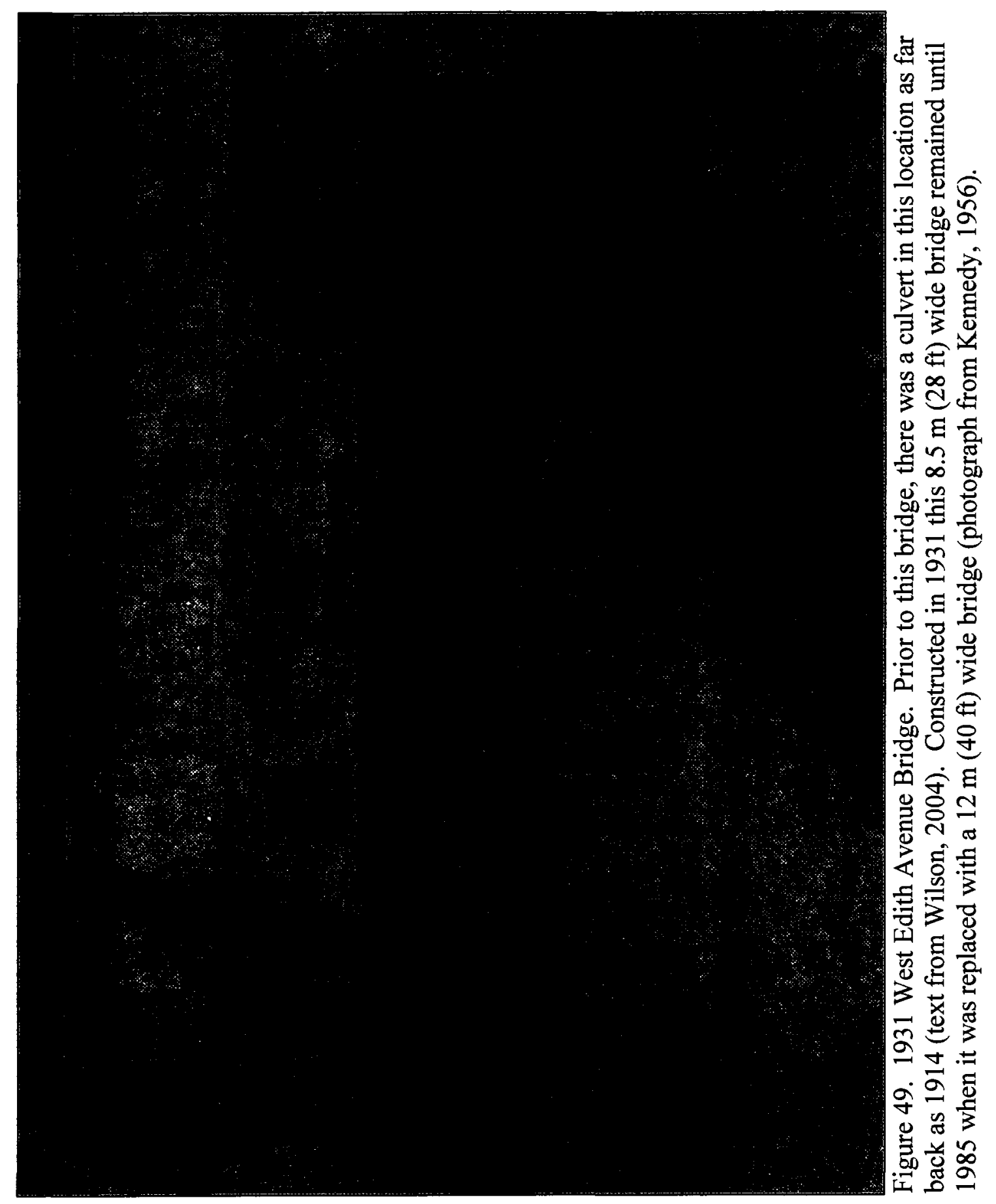


control points for future observation. The control points consisted of $0.9 \mathrm{~m}(3 \mathrm{ft}), 3.8 \mathrm{~cm}$ (1.5 in) iron pipes, each with a plastic survey cap. Creek bends received three pipes on the outside bank: at the beginning, middle, and end of the curve. On the inside bank of the bend, another pipe was set to demark the radius of the curve. Point placements were chosen to be approximately perpendicular to the water flow. The technique for determining perpendicular points on opposite banks was accomplished by a team member standing in the creek, facing downstream, both arms extended at shoulder height to form a $180^{\circ}$ angle with his or her body. The pipe setters would then stand on either side of the creek and line up with the person in the creek or they would instruct the center person to rotate up or downstream. To double check pipes were perpendicular to creek flow, the center person would bring his or her arms together in facing forward to close the angle to zero; if his or her arms were pointing downstream then the locations were perpendicular.

Pipes were also installed at the riffles; there was at least one pair of pipes set for each of the chosen riffles. After the first section of pipes was set, the survey began with a Leica-Wild instrument with three staffs and prisms. Salient features were surveyed including the thalweg, grade breaks, likely bankfull locations (Riley, 1998), bars, top and bottom of riffles, bends, bend pools, step pools, artificial structures such as bridge piers, soffits, weirs and culverts.

\section{Longitudinal Profile}

The long profile data are included in Appendix A. A longitudinal profile along the thalweg of Adobe Creek was surveyed starting in Upper Hidden Villa at an elevation 
of $182 \mathrm{~m}(600 \mathrm{ft})$ for a length of approximately $1980 \mathrm{~m}(6500 \mathrm{ft})$ to the farthest downstream extent of Hidden Villa. The survey continued at the O'Keefe Avenue Bridge downstream almost $3 \mathrm{~km}(9700 \mathrm{ft})$ to Foothill Expressway. Inspection of the longitudinal profile between Manresa Lane and Burke Road shows there are low spots or dips in elevation; these are not snapshots of the headward erosion faces but instead are indicators of bends and associated pools.

\section{Cross-Sections}

Thirty-two cross-sections (Appendix B) were surveyed using an analog level and a telescoping rod. Figure 50 is an index map of the two groups of cross-section and pebble count data collection sites. Figure 51 shows the locations of the cross-sections and pebble counts in the upper watershed in Hidden Villa Open Space Preserve. Figure 52 shows the location of the data sources from O'Keefe downstream to West Edith avenues. A measuring tape was strung between the two pipes on the left and right banks. The level was set up on the left bank in a chosen location in order to provide a clear lineof-sight of both the rod and the area between the two pipes. The "instrument person" recorded the rod height seen through the level, and the distance as read out by the "rod person." At least 12 points along the cross-section were recorded. The "rod person" also provided a descriptor for the point such as toe of bank, thalweg, etc. Bankfull points were chosen based on breaks in slope and changes in the dominant vegetation type. The transition from slender grasses nearest the creek to the upslope perennial broad, leafy 


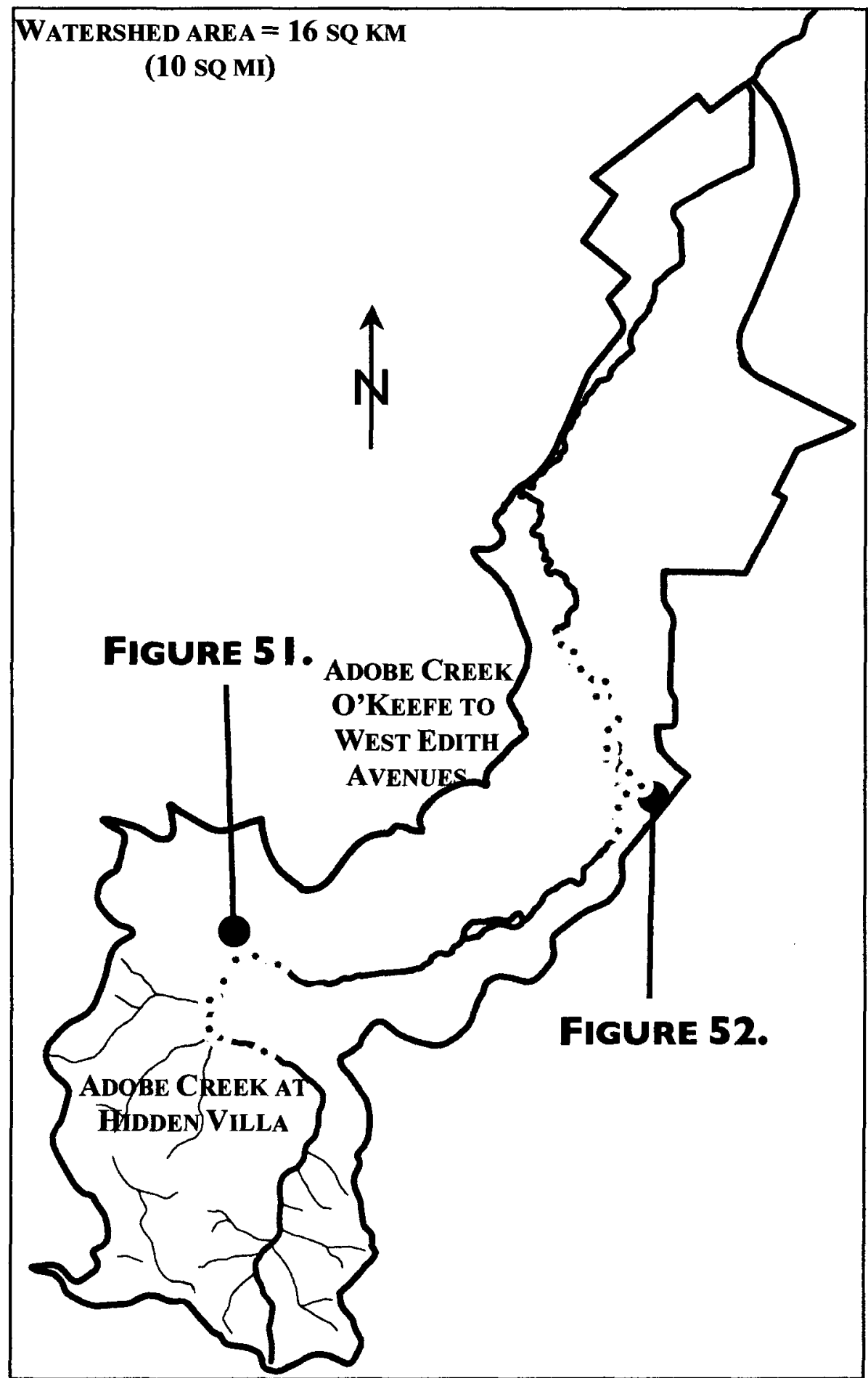

Figure 50. Cross-Section and Pebble Count Location Index Map. Figures 51 and 52 are enlarged maps depicting the location of the surveyed crosssections and pebble counts of Hidden Villa and downstream from O'Keefe to West Edith avenues (modified from SCVWD GIS layer). 




Figure 51. Hidden Villa Cross-Section and Pebble Count Locations. The Upper Adobe Creek Watershed stations are numbered 1 through 12 beginning at the uppermost survey point downstream through Lower Hidden Villa. GCS stands for Geomorphic Cross Section. The label after the number indicates the type of feature and the quantity of cross-sections associated with that station (modified from USGS, 1961). 


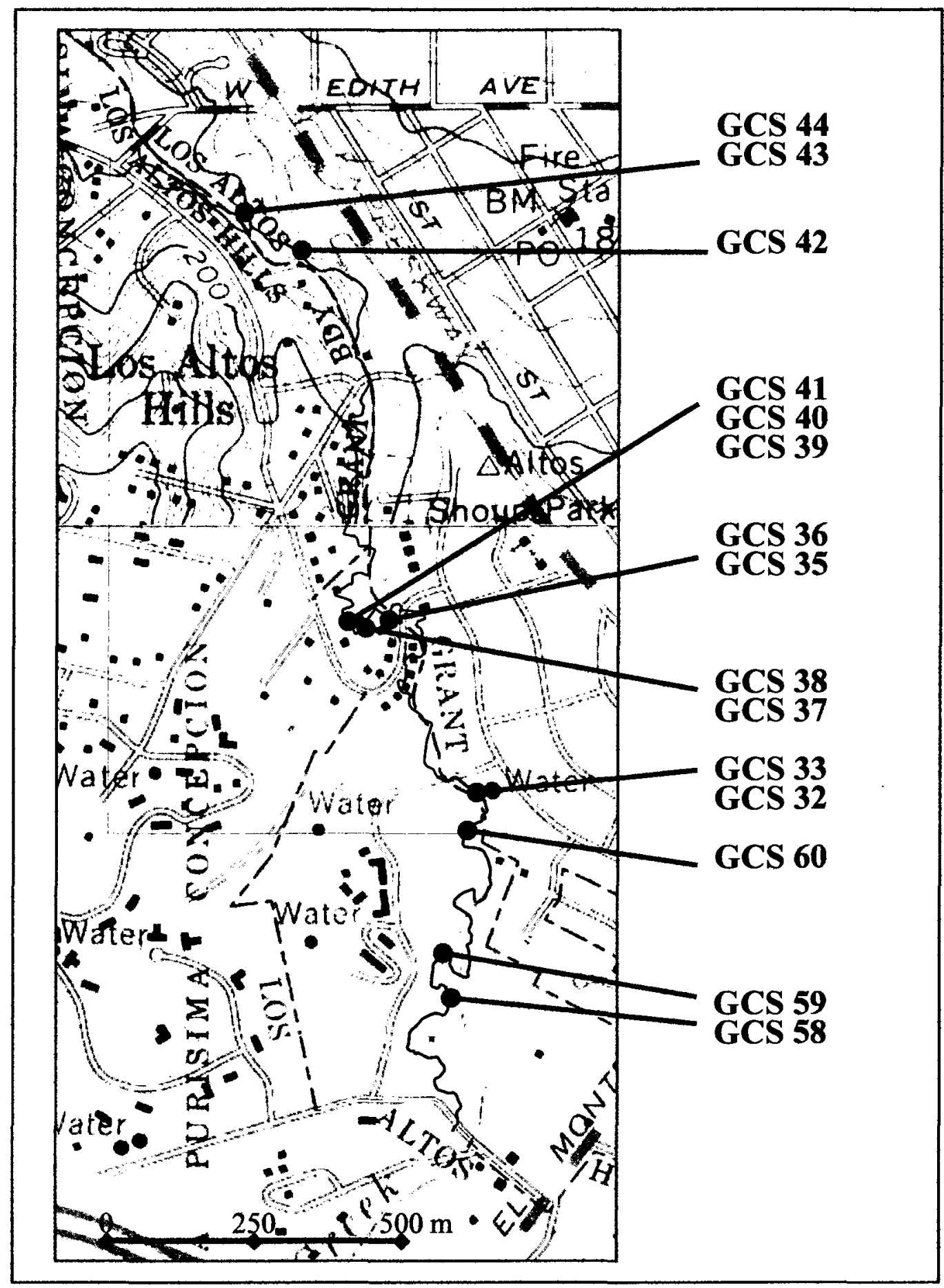

Figure 52. Lower Adobe Creek Cross-Section and Pebble Count Locations. These are the locations of the geomorphic analyses conducted during 2004. Note, the cross-sections were not labeled consecutively (modified from USGS, 1961). 
vegetation away from the creek is usually a good first estimate of the elevation of bankfull flow.

The horizontal and vertical cross-sectional data were input into Excel to graph the elevation of the channel, to calculate bank slopes, and later to be used as the input worksheets for calculating creek forces. On the cross-section, a line was inserted into the graph connecting the two-bankfull points chosen in the field. When only one bank's bankfull elevation could be chosen in the field, a synthetic point was created for calculation purposes. The method used to determine a synthetic bankfull was trial and error. Since the bankfull elevation was known for the opposite bank, only the distance coordinate along the $x$-axis required estimation. A point was inserted into the crosssectional graph with the same elevation ( $y$-axis) but at an approximate distance. Since the recorded points were usually no greater than a meter apart, the data point could be interpolated from the known points along the cross-section. Using this information, a bankfull width and flood prone with could be calculated. The width of the water elevation at two times (2x) the bankfull depth is known as the flood prone width. The flood prone width divided by bankfull width provides the entrenchment ratio.

The entrenchment ratio is a reflection of the ability of the creek to access its flood plain. Increase the entrenchment ratio and the result is a creek that is likely to easily flood or can easily access its flood plain, able to dissipate energy beyond the channel confines. Decrease the entrenchment ratio and the result is a creek that is not likely to flood easily: the creek is disconnected from its flood plain, which causes the creek to concentrate its energy in the channel. The goal is to recreate channel conditions that 
include a creek-accessible flood plain (Riley, 1998). These measurements were used to assist in the calculation of components of creek channel geometry.

\section{Geomorphic Assessment}

\section{Manning's n}

The Modified Cowan's Method (Arcement and Schneider, 1989) was used to determine Manning's $\mathbf{n}$ at each measured cross-section. Manning's $\mathbf{n}$ is a coefficient used to account for channel roughness (Jain, 2001). Manning's $\mathrm{n}$ is equal to the driving forces; the square root of the slope $\left(S^{1 / 2}\right)$ multiplied by the hydraulic radius raised to the two-thirds power $\left(\mathrm{R}^{2 / 3}\right)$, divided by the velocity (V)

$$
n=\left[S^{1 / 2} * R^{2 / 3}\right] / V
$$

In the field, the first step was for the geomorphologists and engineers to make a visual estimation of $n$. The numerical calculation of Manning's $n$ was based on field observations of six components and correction factors that comprise the equation:

$$
\mathrm{n}=\left(\mathrm{n}_{\mathrm{b}}+\mathrm{n}_{1}+\mathrm{n}_{2}+\mathrm{n}_{3}+\mathrm{n}_{4}\right) \mathrm{m} .
$$

The uniformity of channel materials $\left(\mathrm{n}_{\mathrm{b}}\right)$, (e.g., sand, cobbles, concrete) is the base of the calculation. The remaining coefficients account for the effect of surface irregularities on water flow $\left(\mathrm{n}_{1}\right)$; cross-sectional shape and size variation or how frequently the stream shifts laterally within its bed $\left(n_{2}\right)$; the percentage of the creek's cross-sectional area that contain obstructions that impede flow such as bridge piers $\left(\mathrm{n}_{3}\right)$; and type and quantity of vegetation compared to the depth of flow $\left(n_{4}\right)$. These values are 
summed then multiplied by a correction factor to account for the channel sinuosity (m), which is the ratio of channel to valley length (Arcement and Schneider, 1989). Upon completing one's calculations and prior to reaching a final determination of $n$, the group conducted a collective discussion of the creek's geomorphic characteristics and a comparison of the calculated $\mathrm{n}$ with the initial visual estimation.

\section{Pebble Count}

At each surveyed cross-section, a pebble count was completed using the Wolman Pebble Count Method. A pebble count is a blind grab of the first pebble touched as one reaches through the creek to the creek bed. The $b$-axis is measured and recorded. The $a$ axis is the shortest axis of the rock. The $c$-axis is the longest axis of the rock, and the $b$ axis is the intermediate axis. The goal was to make four passes, each pass was done approximately $0.3 \mathrm{~m}(1 \mathrm{ft})$ downstream of the previous pass. The process was devised to evenly space the samples across the cross-section of the creek, moving from one bank to the other, each pass picking 25 samples. After being measured the sample was thrown down stream as to not be counted twice. This information was to be used to determine the $d_{16} d_{50}$ and $d_{84}$. Appendix $C$ includes the individual pebble counts with their corresponding histograms showing the $d_{50}$. The $d_{50}$ or median particle size is the size in $\mathrm{mm}$ where 50 percent of the material is finer than that size and 50 percent is coarser. The $d_{50}$ of Adobe Creek increases in size upstream as the slope increases; the steeper slope contributes to the creek's ability to transport larger material. Therefore, Upper Hidden Villa has the steepest creek slope and, on average, can transport a larger 
median particle-size than the flatter, shallower sloped creek reaches. Figure 53 shows these relations. The uppermost watershed cross-section locations referenced on Figure 53 are on Figure 51 and the cross-sections located on the lower portion of Adobe Creek, downstream of Interstate 280 are shown on Figure 52 . Figure 54 shows the segmentation of the creek, where one major division is visible as the $d_{50}$ grain size decreased from Upper Hidden Villa to Lower Hidden Villa, and then increased again downstream of Interstate 280 only to decrease slightly and remain within a narrow range of values. It could be postulated that had pebble counts been completed farther downstream the result would have been similar, where the first pebble count after the change in creek conditions had a larger $d_{50}$ than the preceding downstream-most pebble count of the prior segment. The size would then decrease and remain within a smaller range of median particle-sizes.

The particle-size data were the input values used in the computer program to calculate the amount of work done by the creek. This information provided the background for designing the new channel dimensions and for determining the median particle-size required for the designed reach.

\section{Section Analyzer}

A computer program, the Section Analyzer was used to calculate stream power. The inputs for the Section Analyzer were the $x$ and $y$ cross-sectional data, the field calculated Manning's $\mathbf{n}$ and the slope (S) from the longitudinal profile. The analyzer then calculated the water surface elevation at increments of $0.15 \mathrm{~m}(0.5 \mathrm{ft})$ added to the previous elevation. The water width and known cross-section geometry provided the 


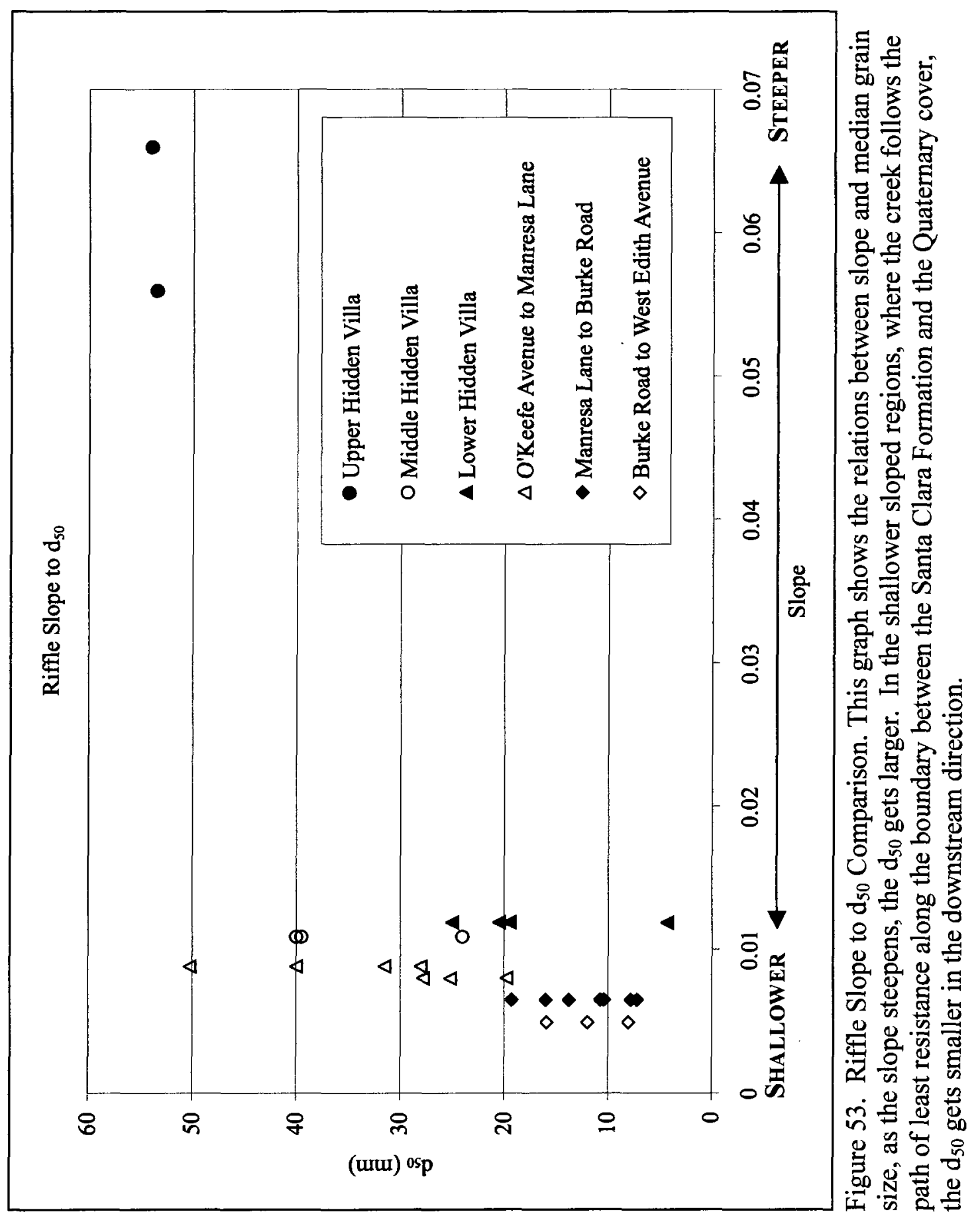




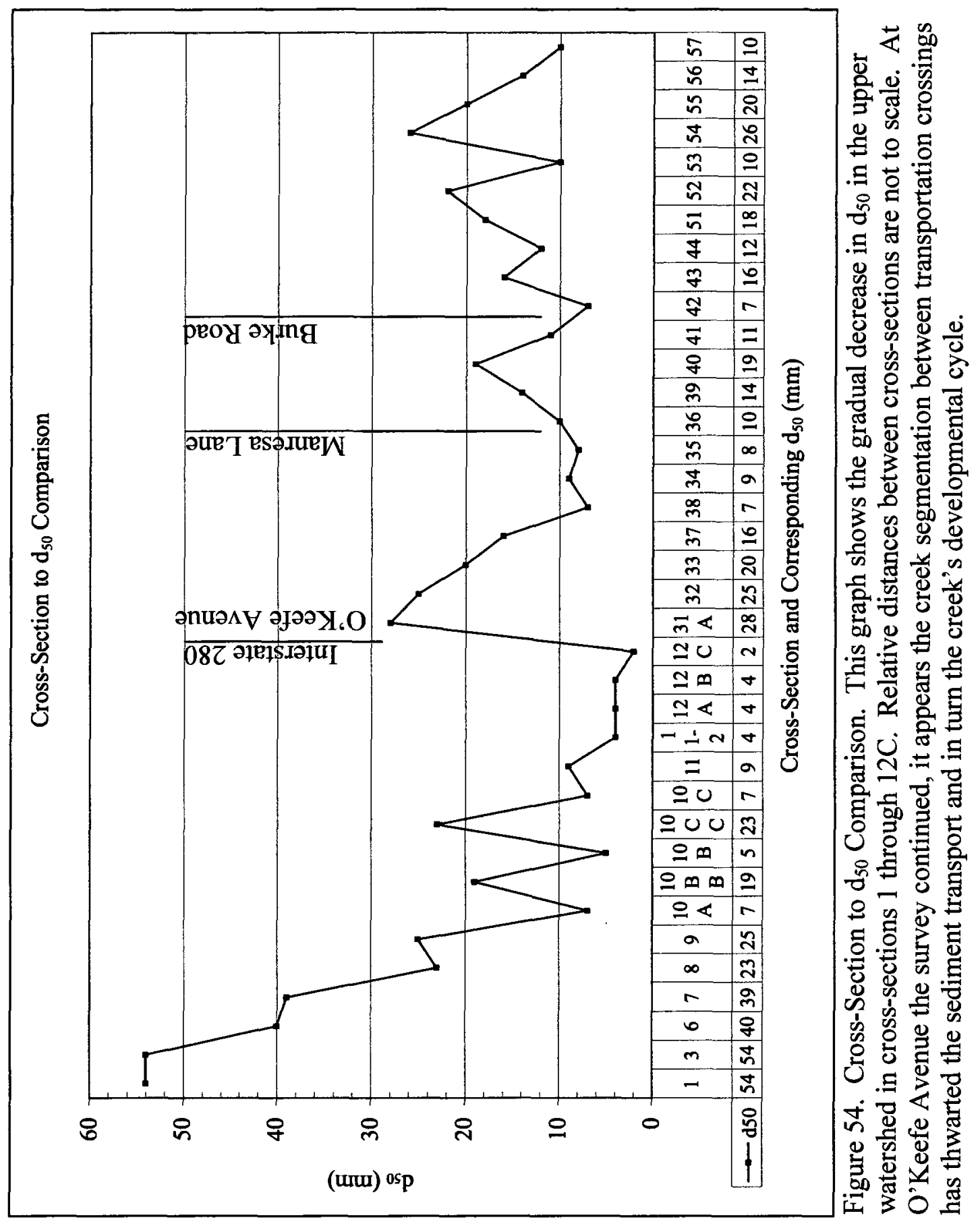


hydraulic radius (R). The hydraulic radius is the area (A) divided by the wetted perimeter (P). This number conveys the efficiency of the creek's cross-sectional shape alternately, how similar the cross-section of the creek is to a half pipe

$$
\mathrm{R}=\mathrm{A} / \mathrm{P} \text {. }
$$

The wetted perimeter is the cross-sectional length of channel that is wet at a particular water surface width (W). Wetted perimeter (P) is two times the depth (d) plus the surface water width (W)

$$
\mathbf{P}=[2 * \mathrm{~d}]+\mathrm{W},
$$

Once it calculated the A and $\mathrm{R}$, the program used those variables to find the discharge $(\mathrm{Q})$. Discharge is expressed as a function of the area $(\mathrm{A})$ of the water in the two-dimensional slice created by the cross-section, multiplied by the hydraulic radius (R) to the two-thirds power multiplied by the slope (S) of the channel to the one half power, all of which divided by Manning's n,

$$
\mathrm{Q}=\left[\mathrm{A} * \mathrm{R}^{2 / 3} * \mathrm{~S}^{1 / 2}\right] / \mathrm{n} .
$$

Manning's $\mathrm{n}$ and the slope were two known quantities from the field measurements. The area (A) and hydraulic radius (R) were derived from the crosssectional data. The program then calculates the conveyance $(\mathrm{K})$, which is used to capture all parts of the discharge equation except the slope, giving rise to the following equation,

$$
\mathrm{Q}=\mathrm{K} * \mathrm{~S}^{1 / 2}
$$

The conveyance $(\mathrm{K})$ is the carrying capacity and is directly proportional to the discharge (Q); it assumes uniform flow (Chow, 1959) and is used to calculate the mid-channel velocity. Discharge $(\mathrm{Q})$ is also a function of the velocity $(\mathrm{V})$ and the area $(A)$, 


$$
\mathrm{Q}=\mathrm{V} * \mathrm{~A} .
$$

Combining the two discharge equations,

$$
\mathrm{K} * \mathrm{~S}^{1 / 2}=\mathrm{V} * \mathrm{~A}
$$

and solving for $\mathrm{V}$, the outcome is

$$
\mathrm{V}=\left[\mathrm{K} * \mathrm{~S}^{1 / 2}\right] / \mathrm{A} .
$$

The program then solves for velocity and determines what the velocities would be at the calculated incremental water elevations. Once the discharge $(\mathrm{Q})$ and wetted perimeter (P) have been calculated, the mid-channel shear stress $(\tau)$ is calculated. The shear stress $(\tau)$ is also called the unit tractive force (Chow, 1959)

$$
\tau=\gamma * \mathrm{R} * \mathrm{~S} .
$$

Using the shear stress $(\tau)$, stream power (SP) can then be calculated. Stream power is the rate of energy acting upon the creek bed and banks. The stream power (SP) is calculated using the specific weight of water $(\gamma)$ multiplied by the discharge $(Q)$ and by the slope (S) and all divided by the wetted perimeter (P); alternately it can be written as an expression

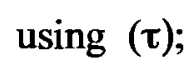

$$
\mathrm{SP}=[\gamma * \mathrm{Q} * \mathrm{~S}] / \mathrm{P} \quad \text { or } \quad \mathrm{SP}=\mathrm{V} * \boldsymbol{\tau} .
$$

The categories of the output data from the Section Analyzer program are as follows: discharge (Q); water surface elevation (wsel); hydraulic radius $(\mathrm{R})$; mid-channel velocity (V); mid-channel stream power (SP); mid-channel shear stress $(\tau)$ and the crosssectional area of each increment calculated (A). These data were linked to the Work Calculator program and were then processed based on an incremental increase in flow and their respective frequencies. The critical shear stress $\left(\tau_{c}\right)$, the force required to 
initiate movement of a given grain size within the context of a mixture of grain sizes, was used to calculate the excess shear and work being done on the bed and banks to determine what flows would be the idealized flows that would minimize the Erosion Potential (EP).

\section{Stable Reaches}

A creek in dynamic equilibrium is characterized when the interdependent variables of erosion, discharge and sediment transport are in balance with one another. This is not an exhaustive list of the variables but includes a few of the important ones. Characteristics of stable reaches include vegetated slopes, which indicate minimal toe erosion and bank instabilities. An accessible flood plain for sediment deposition, storage and energy dissipation is vital during high flows. A stable channel is sized appropriately for the channel forming or bankfull flow events. In the creek bed there is often an armoring of fixed material just below the mobile layer of silts, sands, gravels and small cobbles (Riley, 1998).

The stable reaches surveyed in the upper watershed are within Hidden Villa. Hidden Villa was divided into three hydrologic and topographic categories, Upper, Middle and Lower Hidden Villa; see Figure 55 for the location of these reaches. The Upper Hidden Villa reach is $209 \mathrm{~m}$ long with a gradient of 0.0455 . Figure 56 is at the beginning of the survey of Upper Hidden Villa. This reach maintains a stable-step pool configuration with large boulders; a thick redwood canopy and a Manning's n of 0.06 characterizes this section. This reach was used as a reference for recreating the step pools 


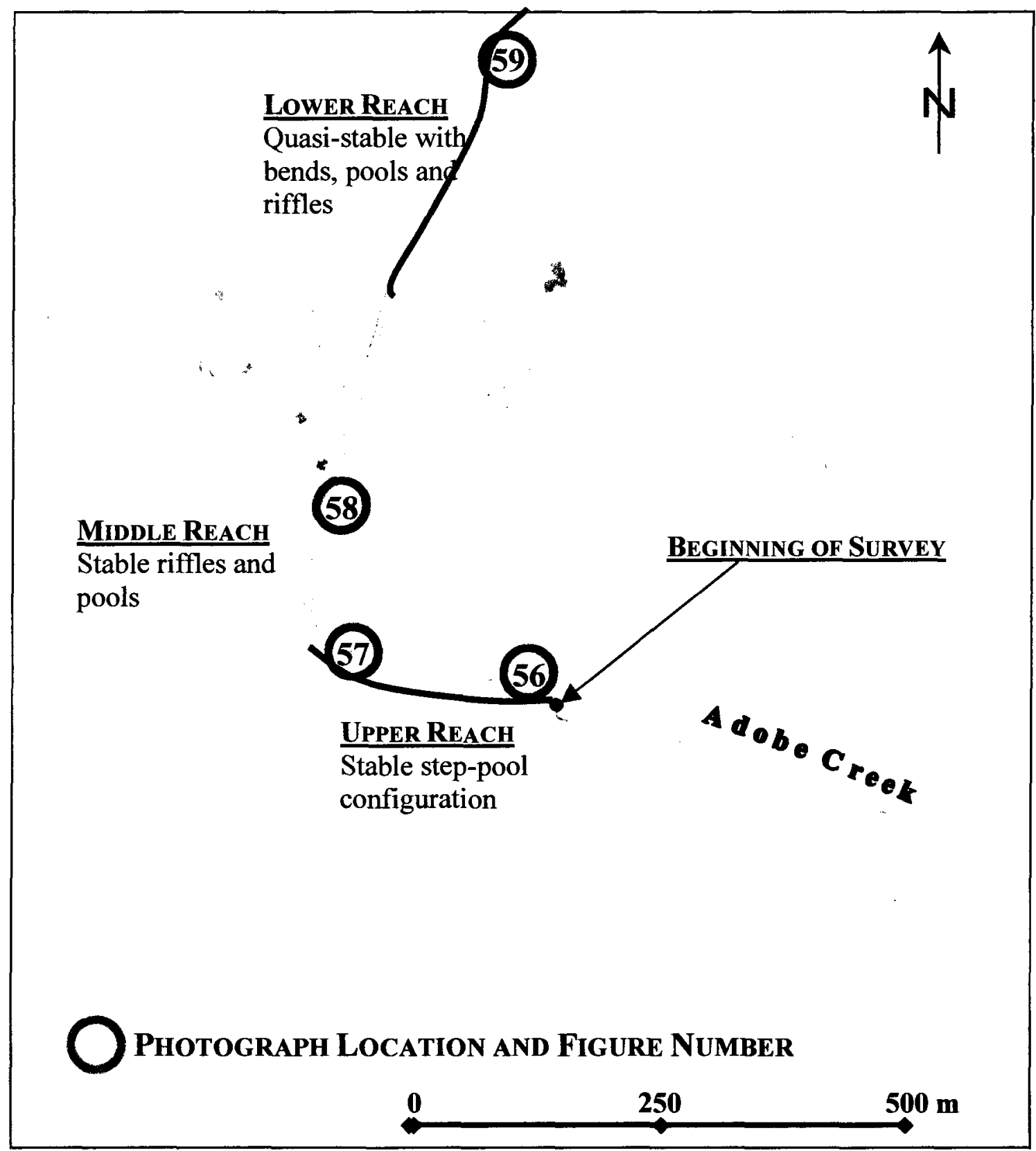

Figure 55. Hidden Villa Photograph Locations. The green circles designate the location of the photograph and its corresponding figure number. Figures 54 through 57 are representative reaches depicting typical geomorphic characteristics (USGS, 1961). 


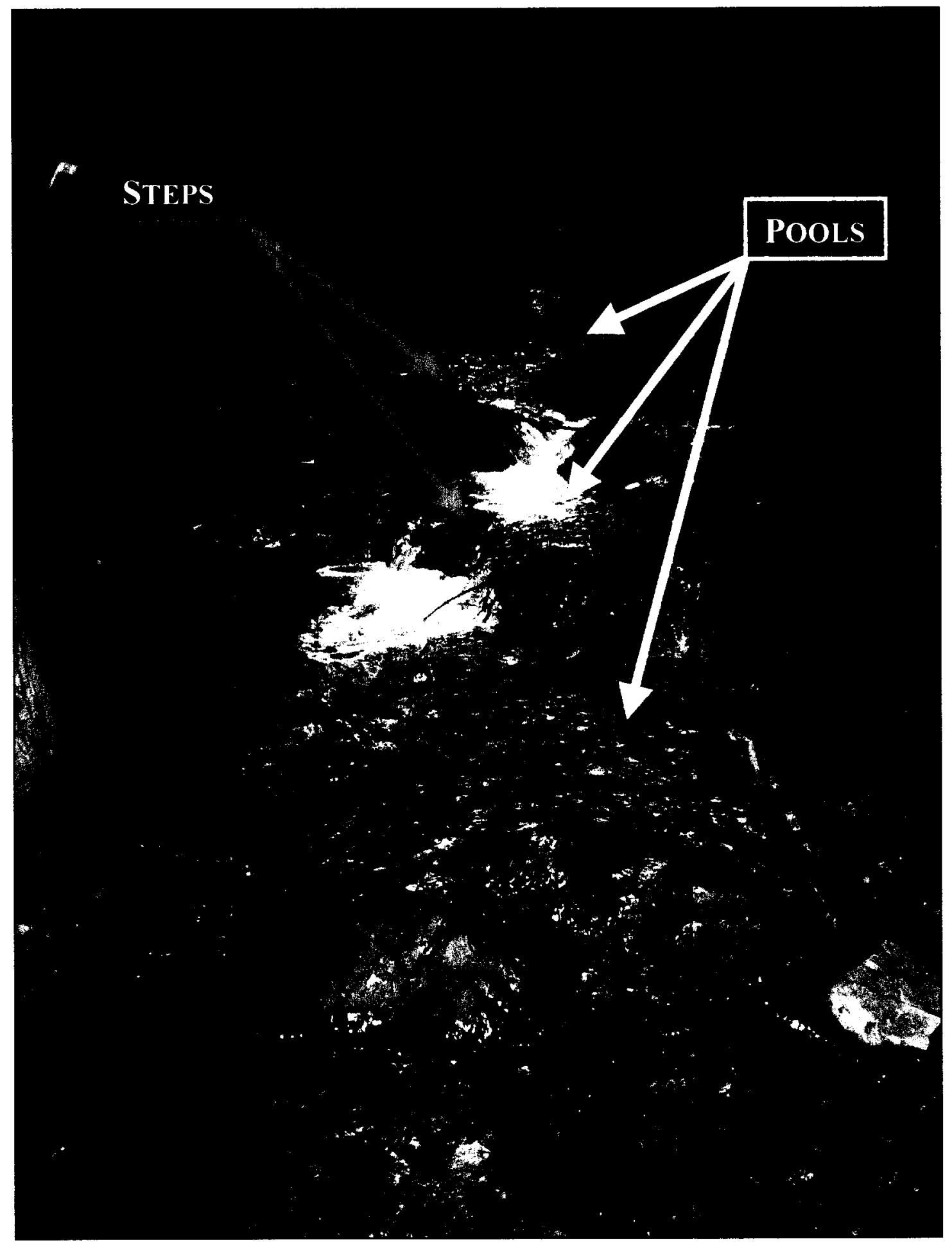

Figure 56. Photograph of Upper Hidden Villa. Looking upstream at the stable steppool configuration (winter 2005). 
in the geomorphic design. Stream steps were required to accommodate the $6.4 \mathrm{~m} \mathrm{(21} \mathrm{ft)}$ elevation change in Upper Reach 5. The total elevation change remains the same, but the step pools dissipate energy and break up the slope into smaller, shorter segments.

The Middle Hidden Villa reach is a stable riffle-pool configuration with a length of $358 \mathrm{~m}$ and gradient of 0.0176 . The Manning's $\mathrm{n}$ for this section is 0.049 . Figure 57 shows the decrease in size of bed material; this is the view downstream. The photograph was taken upstream of the confluence. Figure 58, further downstream, but still within Middle Hidden Villa, shows a cross-section with a stable flood plain. Lower Hidden Villa is a quasi-stable riffle-pool system, but shows signs of undercutting and resulting bank instabilities shown in Figure 59. These conditions exist through the $205 \mathrm{~m}$ long reach with a gradient of 0.010 and a Manning's $n$ of 0.045 . This reach was not used as a reference reach.

Upper and Middle Hidden Villa are stable sections, but the geology underlying these two reaches is quite different from that of Upper Reach 5. The geology of the upper watershed is Franciscan Complex, while the reaches through the residential areas of Los Altos is underlain by the Santa Clara Formation. The younger Santa Clara Formation allows a greater level of erosion than the more resistant Franciscan Complex rocks upstream.

The next section of stable reaches is within the Santa Clara Formation between Manresa Lane and Burke Road at the Redwood Nature Preserve and Shoup Park. It has an average entrenchment ratio of 2.44. The reach average entrenchment ratios for the creek sections surveyed are shown in Table 3. Dr. Sen of the Santa Clara Valley Water 


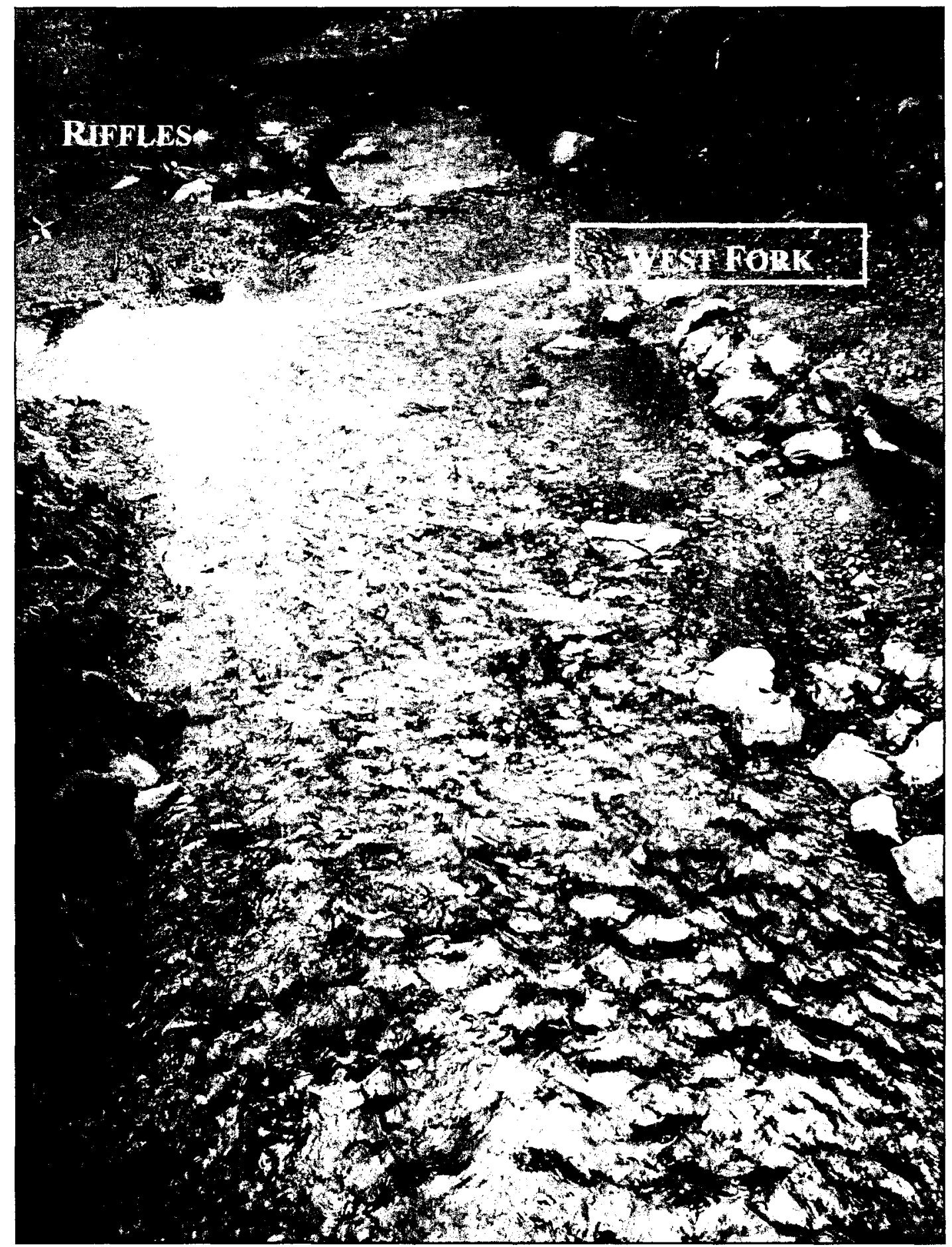

Figure 57. View Downstream, Upstream of West Branch Confluence. This photo was taken at the Upper Extent of the Middle Reach at Hidden Villa, looking downstream from the footbridge at the confluence of the West and Middle Fork of Adobe Creek. It shows the decrease in grain size that is graphed on Figure 54. The riffles with small steps and shallow pools are visible as the creek approaches GCS 5 (winter 2005). 


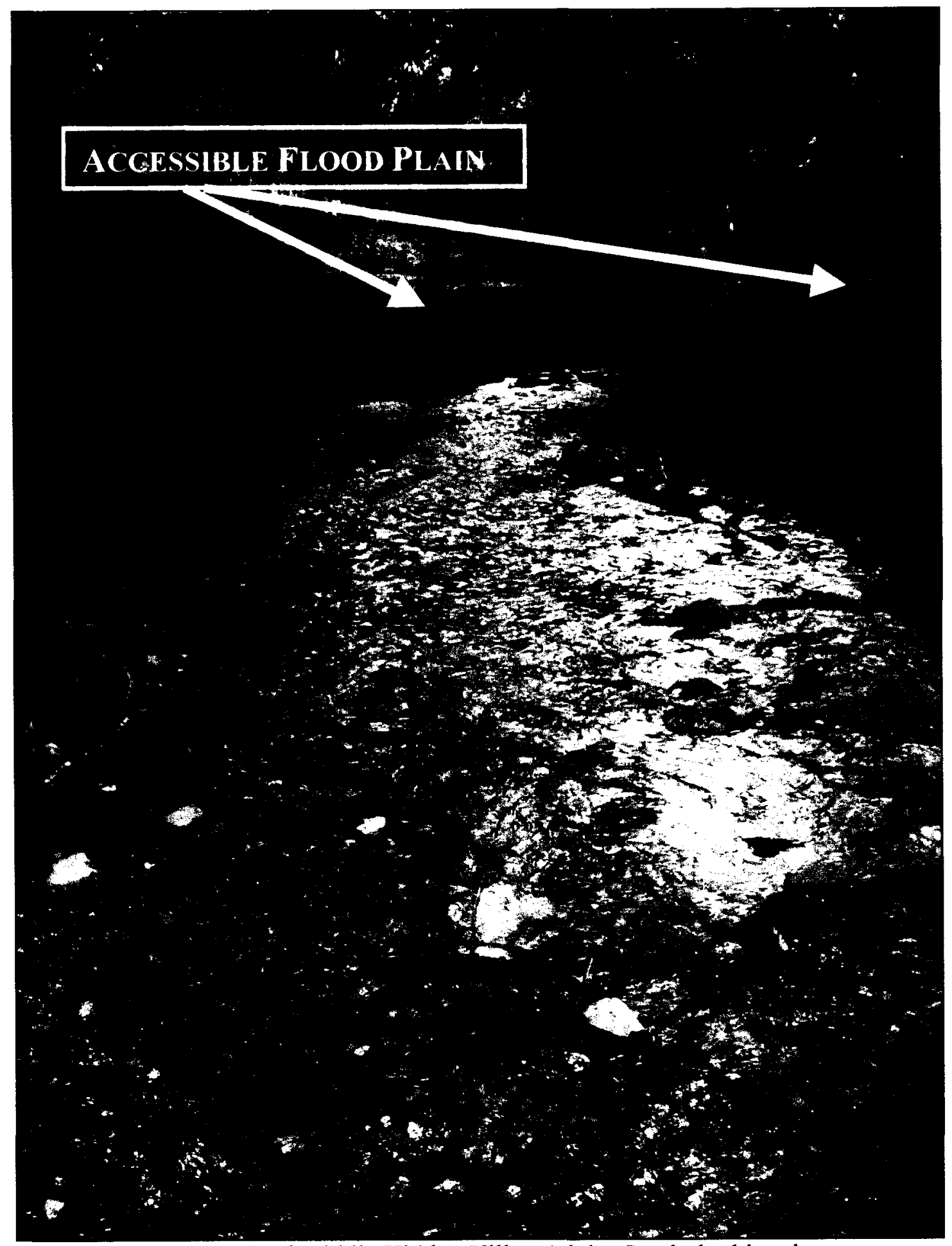

Figure 58. Photograph of Middle Hidden Villa. Adobe Creek, looking downstream at a stable river configuration with well-developed, creek-accessible flood plain (winter 2005). 


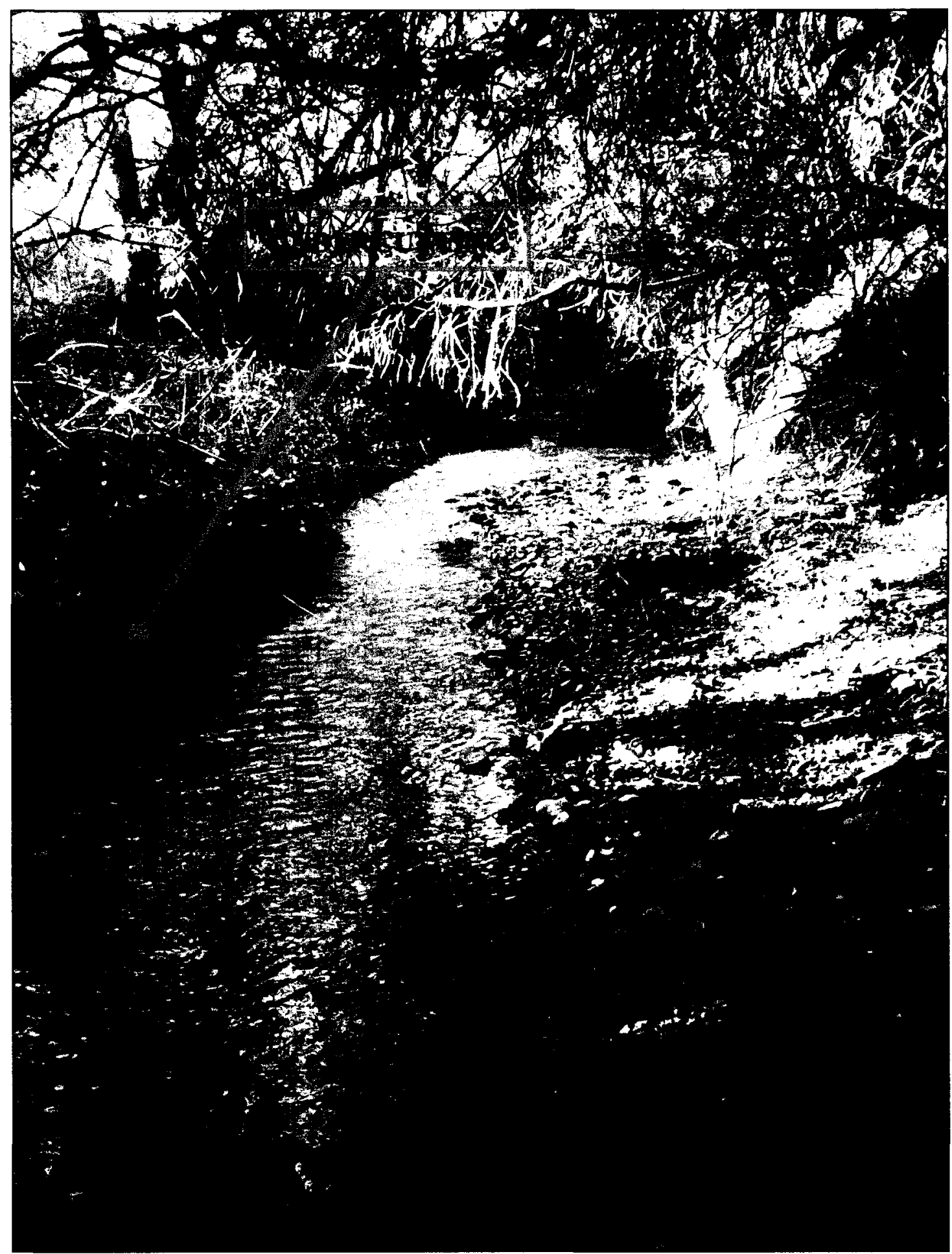

Figure 59. Photograph of Lower Hidden Villa. The perspective of this photo is looking upstream at a quasi-stable reach with some undercutting and exposed roots (winter 2005). 


\begin{tabular}{|c|c|c|c|c|c|c|}
\hline & $\begin{array}{l}\text { Upper } \\
\text { Hidden } \\
\text { Villa } \\
\end{array}$ & $\begin{array}{l}\text { Middle } \\
\text { Hidden Villa } \\
\end{array}$ & $\begin{array}{l}\text { Lower } \\
\text { Hidden Villa } \\
\end{array}$ & $\begin{array}{l}\text { O'Keefe to } \\
\text { Manresa } \\
\text { Rd } \\
\end{array}$ & $\begin{array}{l}\text { Manres } \\
\text { a to } \\
\text { Burke } \\
\text { Rd } \\
\end{array}$ & $\begin{array}{l}\text { Burke } \\
\text { Rd to } \\
\text { W. } \\
\text { Edith } \\
\end{array}$ \\
\hline Notes & $\begin{array}{r}\text { Stable } \\
\text { Step } \\
\text { Pool }\end{array}$ & $\begin{array}{r}\text { Stable Riffle } \\
\text { Pool, Riffles } \\
\text { have small } \\
\text { steps with } \\
\text { pools, bends } \\
\text { have pools }\end{array}$ & $\begin{array}{r}\text { Meta Stable } \\
\text { Riffle \& } \\
\text { Bend Pool }\end{array}$ & $\begin{array}{r}\text { Incised, } \\
\text { some } \\
\text { instability } \\
\text { (sections } \\
31,32,33 \\
58,59)\end{array}$ & $\begin{array}{r}\begin{array}{r}\text { Stable } \\
\text { (section }\end{array} \\
\text { s 36, 37, } \\
38,39 \text {, } \\
40,41 \text { ) }\end{array}$ & $\begin{array}{r}\text { Unstabl } \\
\text { e } \\
\text { (section } \\
42,43, \\
44)\end{array}$ \\
\hline \multicolumn{7}{|l|}{ Reference Reaches } \\
\hline $\begin{array}{l}\text { Surveyed reach length } \\
\text { (ft) }\end{array}$ & 686 & 1,176 & 674 & 3,611 & 4,076 & 2,394 \\
\hline \multicolumn{7}{|l|}{$\begin{array}{l}\text { Rehab Stream Reach } \\
\text { Length (ft) }\end{array}$} \\
\hline Beginning Elevation & 601.9 & 570.7 & 537.9 & 255.5 & 212.0 & 181.6 \\
\hline Ending Elevation & 570.7 & 550.2 & 529.6 & 212.0 & 181.6 & 166.3 \\
\hline Stream Gradient $(\mathrm{ft} / \mathrm{ft})$ & $4.55 \%$ & $1.76 \%$ & $1.00 \%$ & $1.21 \%$ & $0.75 \%$ & $0.64 \%$ \\
\hline Beltwidth (ft) & 57 & 51 & 72 & 449 & 429 & 381 \\
\hline Meander Amplitude (ft) & 29 & 21.1 & 32 & 97 & 151 & 89 \\
\hline Meander Length ( $\mathrm{ft}$ ) & 107 & 98.3 & 77 & 86 & 157 & 190 \\
\hline Radius of Curvature (ft) & 59 & 84 & 58 & 39 & 43 & 61 \\
\hline Riffle Length (ft) & - & 70.4 & 78 & 84 & 27 & 61 \\
\hline $\begin{array}{l}\text { Riffle Gradient (ft/ft) } \\
\text { excluding steps }\end{array}$ & - & $0.70 \%$ & $1.73 \%$ & $0.64 \%$ & $1.95 \%$ & $0.49 \%$ \\
\hline $\begin{array}{l}\text { Riffle Gradient }(\mathrm{ft} / \mathrm{ft}) \mathrm{w} / \\
\text { steps }\end{array}$ & & $1.80 \%$ & & & & \\
\hline Step Pool Length (ft) & 3.10 & - & - & - & 8.17 & - \\
\hline Step Pool Drop (ft) & 1.18 & - & - & - & 0.85 & - \\
\hline $\begin{array}{l}\text { Bankfull Width (ft) at } \\
\text { Riffle }\end{array}$ & 13.03 & 15.20 & 16.56 & 13.23 & 14.70 & 14.40 \\
\hline Bankfull Depth (ft) & 2.46 & 2.09 & 1.86 & 1.85 & 1.46 & 2.17 \\
\hline Bank Height (ft) & 6.41 & 5.24 & 8.17 & 6.59 & 2.57 & 4.22 \\
\hline $\begin{array}{l}\text { Bank Slope Angle } \\
\text { (degrees) }\end{array}$ & 145.25 & 146.33 & 150.90 & 158.50 & 141.20 & 135.00 \\
\hline Width to Depth ratio & 5.90 & 7.52 & 9.62 & 7.67 & 11.07 & 6.65 \\
\hline Entrenchment ratio & 1.53 & 2.03 & 2.34 & 1.37 & 2.44 & 1.54 \\
\hline Sinuosity & 1.12 & 1.12 & 1.10 & 1.87 & 1.77 & 1.24 \\
\hline $\begin{array}{l}\text { Bank Height/Bankfull } \\
\text { Depth }\end{array}$ & 2.71 & 2.08 & 4.72 & 3.86 & 2.76 & 1.97 \\
\hline $\begin{array}{l}\text { Beltwidth/Bankfull } \\
\text { Width ratio }\end{array}$ & 4.59 & 3.41 & 4.44 & 35.09 & 35.90 & 26.75 \\
\hline $\begin{array}{l}\text { Rad. of } \\
\text { Curvature/Bankfull } \\
\text { Width }\end{array}$ & 4.75 & 5.62 & 3.57 & 3.05 & 3.51 & 4.28 \\
\hline $\begin{array}{l}\text { Amplitude/Bankfull } \\
\text { Width }\end{array}$ & 2.34 & 1.41 & 1.97 & 7.58 & 8.28 & 6.25 \\
\hline
\end{tabular}


District suggests that the design entrenchment ratio should be greater than 2.4 , and in the range of 2.5 to 4 for a stable channel (2005).

The reaches through the parks have a stream gradient and vegetated cover comparable to the desired restored Upper Reach 5. The length of this section is $1242 \mathrm{~m}$ and has a gradient of 0.0075 . The vegetation varies from scattered stands of redwood, oak, buckeye, bay, sycamore and toyon trees with low shrubs and saplings to thickets of vines and grasses. Figure 37 shows the well-formed bends and riffles in the Redwood Grove, and Figure 60 shows the vegetated flood plain in Shoup Park.

The results of the geomorphic investigation, surveys, office calculations and the hydraulic modeling indicate that the minimum bankfull width for riffles is about $4.5 \mathrm{~m}$ $(15 \mathrm{ft})$ and the width of the bends at $5.3 \mathrm{~m}(17.5 \mathrm{ft})$. The original geomorphic solution, alternative 2 on Table 4, has a low-flow channel of $5 \mathrm{~m}$ (17 ft) wide with $3 \mathrm{~m}$ (10 ft) wide benches on both sides and 1:1 bank slopes (SCVWD, 2007a). This design alternative did not fit within the Collaborative's agreed upon right-of-way or "blue line limits" (Figure 6).

\section{ENGINEERING}

\section{Paleochannels}

Opportunities for future watershed improvements include reconnecting the active creek to its paleochannels. Paleochannels are ephemeral creek branches that are no 


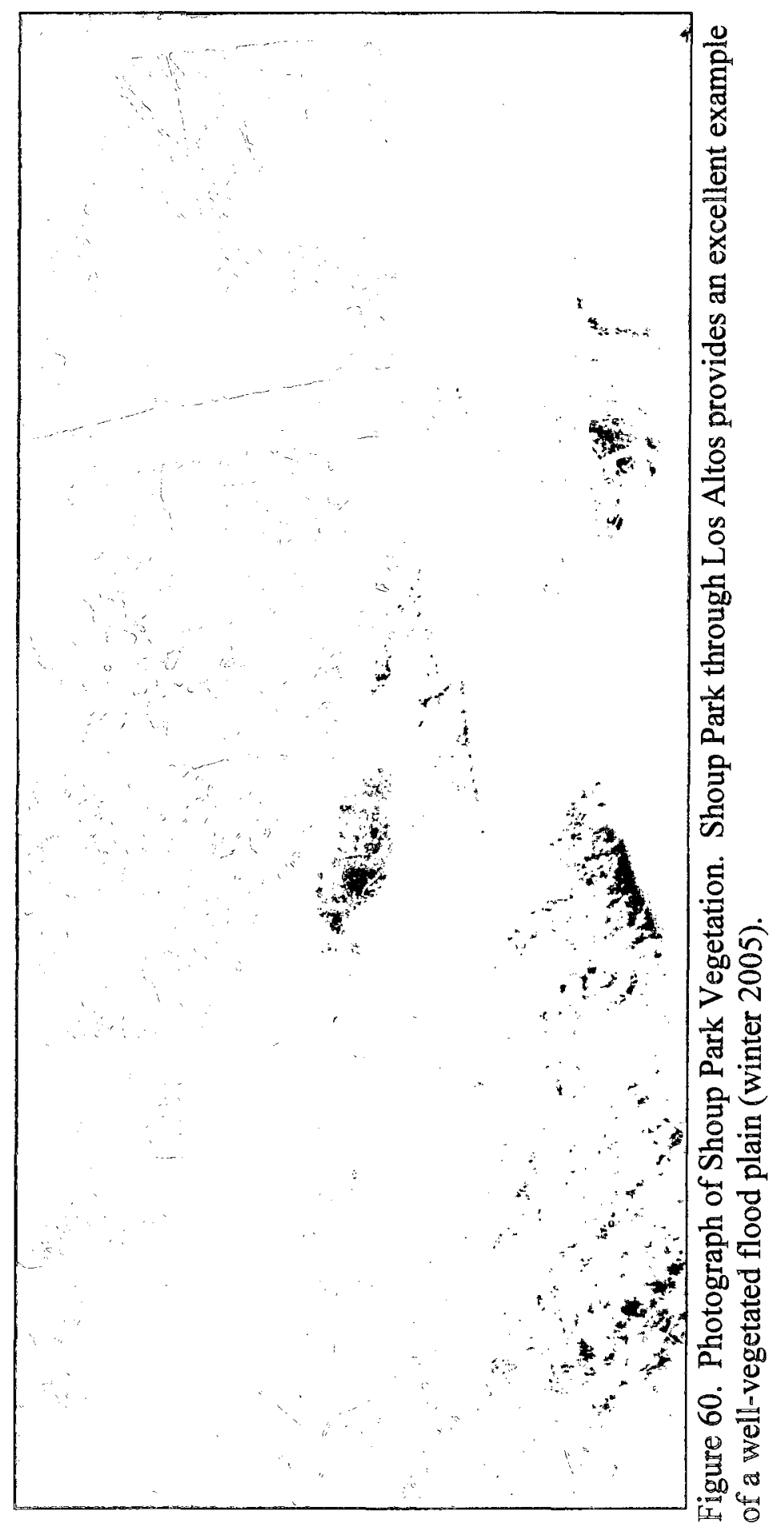




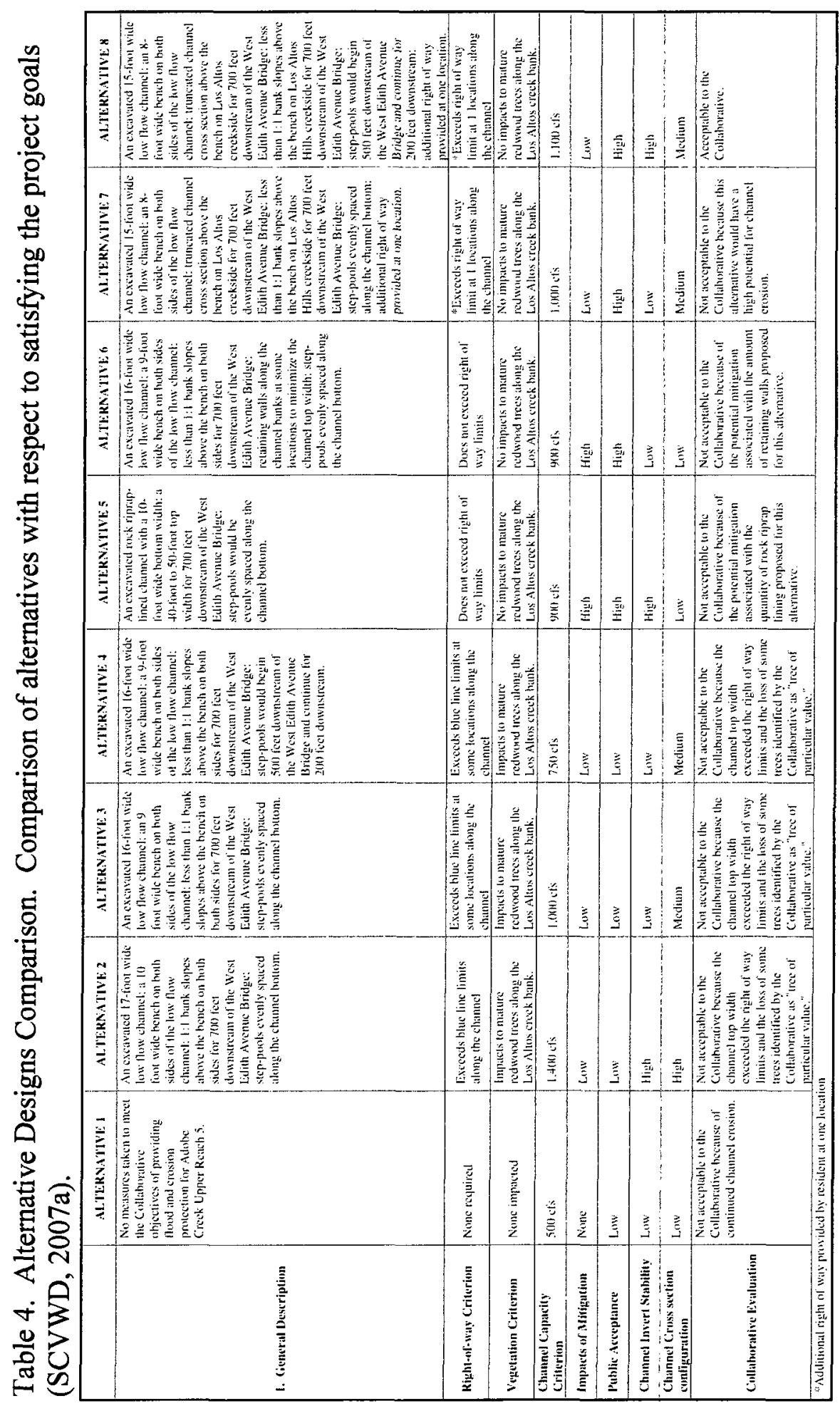


longer part of the modern creek system. These waterways were inundated during high

flows. The concept behind reconnecting the paleochannels is to decrease the stream gradient in the lower watershed and return the flow conditions to something that approximates ephemeral. The paleochannels are not channelized but they have been urbanized and converted to residential developments. The paleochannels are still at approximately the same elevation that they were when the creek used them to dissipate flow and energy. The paleochannels could be a valuable resource used for groundwater recharge. Returning a portion of the land to its preurbanized condition could eventually reduce the need for regular maintenance activities such as periodic in-channel sediment removal.

Figure 30 shows the paleochannels in green. One paleochannel parallels San Antonio Road. This location would be an excellent opportunity to incorporate the next series of road repairs and renovations with creek restoration. If creeks can be reintroduced into the neighborhoods, these areas could be used for community outreach; education and then perhaps, with the support of the community, further restoration activities could be developed.

\section{Transportation Corridor Modifications}

Establishing a continuous riparian corridor would improve the channel function and dissipate energy. When designing a replacement transportation corridor, the bridge should be wide enough so that the creek can have a continuous riparian corridor 
underneath it. Box culverts truncate the riparian corridor and are not as effective as a continuous thread of vegetation. Modifications made to existing roadways could assist by allowing the floodwaters to pass beneath bridge crossings. The construction of rolling dips approximately parallel to the direction of flow could direct the overland flow across the roadway and back into the creek at desired locations.

\section{Evolution of Project}

One option examined was the consequences of no project; Adobe Creek would just be left "as is" and the creek would continue to undermine gunnite toe protection. The creek beds would continue to vary from concrete to sand to human-placed large boulders as well as unplaced and misplaced hardscape. The wood retaining walls would slowly submit to gravity with the creek eroding around them. At the West Edith Avenue Bridge, sediment deposition would continue to further decrease the flow capacity and increase the flow velocity. The loosely termed riparian corridor would remain the same with both native and non-native species. The aesthetic quality would continue to degrade as the potential for increased loss of property due to erosion remained unabated.

A design solution was needed to the address the area of Upper Reach 5. In the beginning of the Upper Reach 5 project, the solution was dominated by geomorphic conditions and as the project evolved, it slowly moved away from the geomorphic focus as the overriding factor. The geomorphic design fell short of remaining inside the community's agreed-upon width restrictions. To reach a compromise with the residents' 
requests that the creek not extend past the "blue line limits" (Figure 6) and not remove trees of particular value, the design was retooled and modified little by little until the overall width of the creek was smaller than the geomorphic design, but fit within the right-of-way. Each iteration narrowed the project footprint and reduced the real estate requirements needed to provide a new design. The project became less centered on a pure geomorphic restoration and more about fitting within the urban constraints. See Table 4 for an itemized outline of the major elements of the eight proposed project alternatives. The final result was a compromise that attempted to satisfy all voiced parties involved. The design included a low-flow channel $4.5 \mathrm{~m}(15 \mathrm{ft})$ wide with a $2.4 \mathrm{~m}$ (8 ft) bench on both sides and remained within the "blue line limits" (SCVWD, 2007a).

\section{FURTHER RESEARCH}

Further research regarding the geomorphic evolution of Adobe Creek could help a future holistic systems approach. Determining the degree of influence of the carbonate cementation on the watershed as a system is an important component in understanding the sediment budget of this creek. Another unexplored avenue of research is a comparison of Adobe Creek to nearby Matadero and Barron Creek watersheds. Additionally, a comparison to less urbanized creeks farther south could help elucidate the controls of range-front creeks that cross reverse faults. It should be established whether prior to human arrival, the creek behaved in the typical textbook fashion where changes cascaded through the creek system. It should be determined if there once existed a state 
of dynamic equilibrium to which the creek can be returned. Application of the traditional sense of dynamic equilibrium on a creek with a cemented upper watershed may not recreate an ideal functioning system.

\section{CONCLUSIONS}

To address the current and continual evolutionary state of the creek, a regional systems approach was needed rather than a patchwork fix. The systems approach requires a multi-faceted examination of the watershed as a whole, including cultural context and historical relevance.

The solution implemented is limited to a small portion of Adobe Creek. To address the instabilities at a systems level, the project scope would need to be larger; ideally the localized solution should extend upstream to O'Keefe Avenue and downstream to Foothill Expressway. Ideally, the broad view is to address the whole watershed but at this juncture, an extension of the area being addressed for the Upper Reach 5 repairs would be beneficial toward a stable creek.

To create a stable channel from a highly entrenched one, there are two options: the creek can be widened to decrease the amount of work being done on the channel by the water, spreading the water over a larger area. The second option is to raise the bottom of the creek so it can reconnect with its original flood plain. It would be advantageous to utilize normal creek functions of erosion and sediment transport to do the work. The introduction of small grade control structures at the bottom of the reach 
would create conditions where the creek would build up the bottom of the channel over time. The creek should be allowed to maintain the shallower angle it has developed in the lower watershed.

The hydraulic modeling done shows that the geomorphic solution was designed to pass flows up to $1400 \mathrm{cfs}$. The chosen alternative has a design capacity of $1100 \mathrm{cfs}$, which correlates to just under the 10-year rain event. This design alternative allows the backyards beside the creek to accommodate the overflow. The previous channel had an approximate capacity of only $500 \mathrm{cfs}$. The implemented design is an improvement, however the creek demonstrated stable configurations in the upper watershed and throughout the public parks. The urban constraints and public opinions required a compromised solution, which ultimately compromised the geometry of the geomorphic solution.

Solutions for a holistic systems approach to creek restoration include flood plain reconnections, future replacement of narrow transportation corridors and providing the creek with what it naturally requires. Developing a solution that minimizes or excludes synthetic materials helps reduce the potential need for future human intervention. Residents have agreed to reduced protection from the less-than-10-percent-flood; this means they have also agreed to allow Edith Park flood and flow over West Edith Avenue. The flow is routed though the backyards and reenters the channel approximately $213 \mathrm{~m}$ (700 ft) downstream of West Edith Avenue (SCVWD, 2007a). Residents have accepted a higher level of risk because their remembered experiences of the flooding in the recent past is less extreme than the models predicted it should be (SCVWD, 2007a). A design 
solution not based on the geomorphic needs of the existing creek provides a solution that is on a human time-scale and consequently results in a smaller scoped project. The project should alleviate the immediate threats of failing bank protection structures and allow for more water to be conveyed within the channel. The implemented design capacity is for approximately the 10 -year flows. 


\section{REFERENCES CITED}

Ableiter, J.K., Barnes, C.P., Roberts, R.C., Lapham, M.H., Gardner, R.A., Hargreaves, G.H., Harradine, F.F., Retzer, J.L., Bartholomew, O.F., and Glassey, T.W., 1958, Soil Map: Santa Clara County Area, California, Northern Sheet. United States Department of Agriculture, Soil Conservation Service, University of California Agricultural Experiment Station, scale 1:50 000, 5 Sheets.

Allardt, G.F., 1862, Map of the San Francisco and San José Railroad: as located by the directors. San Francisco: Lith. Britton and Co. in Santa Clara Valley Water District: Lower Peninsula Watershed Stewardship Plan: Chapter 9 Adobe Creek Watershed Management Unit, 2005.

Arcement, G.J., Jr., and Schneider, V.R., 1989, Guide for selecting Manning's roughness coefficients for natural channels and floodplains. U.S. Geological Survey Water Supply Paper 2339, $67 \mathrm{p}$.

Association of Bay Area Governments: 1990, Census Data from ABAG (rev. 2/9/98) http://www.abag.ca.gov/bayarea/census90/pickhtml.html, (last accessed 3/12/05).

Barnes, C., 1998, Los Altos Town Crier: A Cranston Inspiration. Los Altos, CA. http://latc.com/1998/05/18/special_sect/yourhome5.html, (last accessed 02/14/05).

Bates, K., 2004, Stream Habitat Restoration Guidelines, Washington Department of Fish and Wildlife, U. S. Fish and Wildlife Service Washington; Department of Ecology, Hydraulics Appendix, 29 p.

Bolt, B.A., 1993, Earthquakes: Revised and Updated. W.H. Freeman and Company, New York, 331 p.

Brabb, E.E., Graymer, R.W., and Jones, D.L., 1998, Geology of Palo Alto 30 X 60 minute quadrangle, California: A Digital Database: U.S. Geological Survey, Digital Open-File Report 98-348, scale 1:100 000, 2 sheets, 32 p. text.

2000, Geologic map and map database of the Palo Alto 30' x 60' quadrangle, California: U.S. Geological Survey, Miscellaneous Field Studies Map MF-2332, scale 1:100 000, 2 sheets.

California Department of Water Resources in cooperation with the Santa Clara Valley Water District, 1975, Evaluation of Ground Water Resources: South San Francisco Bay, Northern Santa Clara County Area, Volume III; Bulletin No. 118$1,133 \mathrm{p}$. 
http://www.archive.org/stream/evaluationofgrou11811975calirich\#page/n153/mo de/2up, (last accessed 09/08/09).

California Regional Water Quality Control Board, 2003, San Francisco Bay Region Groundwater Committee, A Comprehensive Groundwater Protection Evaluation for the South San Francisco Bay Basins, 251 p.

Cartier, R., Crane, L., James, C., Reddington, J., and Ruby, A., 1991, The Santa's Village Site CA-SCr=239: De Anza College: An Overview of the Ohlone Culture, Santa Cruz Public Libraries http://www.santacruzpl.org/history/spanish/ohlone.shtml, (last accessed 10/15/07).

Chow, V.T., 1959, Open-channel hydraulics: New York, McGraw-Hill Book Co., 680 p.

Connor, A., and Marshall, A., eds., 1973, Los Altos Reminiscences: Cupertino, CA, De Anza College California History Center, 64 p.

Coppersmith, K.J., 1990, The Zayante-Vergeles fault zone in Field Guide to Neotectonics of the San Andreas fault system, Santa Cruz Mountains, in light of the 1989 Loma Prieta Earthquake: U.S. Geological Survey Open-File Report 90-274, 14 p.

Cotton, W., and Associates, 1975, Analysis of the Geotechnical Hazards of the Town of Los Altos Hills, 41 p.

Edwards, J., 2005, Los Altos Town Crier: Community, Los Altos, CA. http://losaltosonline/2005/05/25/community/communityl.html, (last accessed 10/16/07).

Fava, F.M., 1976, Los Altos Hills: The colorful story: Woodside, CA, Gilbert Richards Publications, $135 \mathrm{p}$.

Fio, J.L., and Leighton, D.A., 1995, Geohydrologic Framework, Historical Development of the Ground-Water System, and General Hydrologic and Water-Quality Conditions in 1990, South San Francisco Bay and Peninsula Area, California, U.S. Geological Survey Open File Report 94-357, 46 p.

Gardner, R.A., Harradine, F.F., Hargreaves, G.H., Retzer, J.L., Bartholomew, O.F., and Glassey, T.W., 1958, Soil Survey: Santa Clara Area, California. United States Department of Agriculture, Soil Conservation Service, University of California Agricultural Experiment Station Series 1941, No. 17.

Geschke, N., 1998, Los Altos History Show \#41, Reminiscences about Life in Early Los Altos, Ruth Eleanor Cranston Cameron Interview. Los Altos Historical Commission. 
Givler, R.W., and Sowers, J.M., 2005, Creek and Watershed Map of West Santa Clara Valley: Oakland Museum of California, Oakland, CA, scale 1:25 800, 1 sheet.

Graymer, R.W., Jones, D.L., and Brabb E.E., 1994, Preliminary geologic map emphasizing bedrock formations in Contra Costa County, California: A digital database U.S. Geological Survey Open-file Report 94-622.

Grossinger, R., 2001, Documenting local landscape change: The San Francisco Bay Area historical ecology project, in Egan, D., and Howell, E.A., eds., The historical ecology handbook: A restorationists guide to reference ecosystems. Washington, D.C.: Island Press, 425 p.

Grossinger, R.M., and Askevold, R.A., 2005, Baylands and Creeks of South San Francisco Bay: Oakland Museum of California, Oakland, CA, scale 1:25 800, 1 sheet.

Henderson, F.M., 1966, Open Channel Flow: Macmillan Publishing Company, Inc., New York, $511 \mathrm{p}$.

Hill, A., 2001, Los Altos Town Crier: How Adobe Creek was Rerouted. Los Altos, CA. http://atc.com/2001/09/05/community/communit4.html, (last accessed 3/20/05).

Hitchcock, C.S., Kelson, K.I., and Thompson, S.C., 1994, Geomorphic Investigations of Deformation Along the Northeastern Margin of the Santa Cruz Mountains, U.S. Geological Survey Open File Report 94-187, 53 p.

Holland-Clift, S., and Davies J., 2007, Willows Management Guide: Department of Primary Industries, Victoria, p. 1-22.

Hoover, M.B., Rensch, H.E., and Rensch, E.G., 1958, Historic Spots in California: Stanford, California, Stanford University Press, 411 p.

Jain, S.C., 2001, Open-Channel Flow: John Wiley and Sons, Inc., New York, 328 p.

Kennedy, C.C., 1956, Report on Adobe Creek Improvement Project No. NW-1-4 Santa Clara County Flood Control and Water Conservation District.

Langenheim, V.E., Schmidt, K.M., and Jachens, R.C., 1997, Coseismic deformation and range-front thrusting along the southwestern margin of the Santa Clara Valley, California: Geology, v. 25, p. 1091-1094.

Leopold, L.B., Wolman, M.G., and Miller, J.P., 1964, Fluvial Processes in Geomorphology: Dover Publications, Inc., Mineola, New York, 522 p. 
Los Altos Chamber of Commerce: Community Profile, 2004. http://www.losaltoschamber.org/community_profile.html, (last accessed 02/14/05).

McArthur, S., ed., 1981, Water in the Santa Clara Valley: A history: Cupertino, CA, California History Center DeAnza College, Local History Studies, Vol. 27. 155 p.

McDonald, D., 2001, Los Altos Town Crier: Los Altos in the 1930's, questions and answers, http://latc.com/2001/05/30/community/communit1.html, (last accessed 02/14/05).

Miller, L., 1964, Water Supply Investigation: North Los Altos Water Co. State of California- Health and Welfare Agency: Department of Public Health: Bureau of Sanitary Engineering, $25 \mathrm{p}$.

Oakeshott, G.B., 1971, California's Changing Landscapes: A Guide to the Geology of the State. McGraw-Hill, Inc., San Francisco, 388 p.

Poland, J.F., 1984, Guidebook to Studies of Land Subsidence due to Ground-Water Withdrawal. Case History No. 9. 14. Santa Clara Valley, California U.S.A., published by UNESCO, printed under direction if the American Geophysical Union. pp. 279-290.

Riley, A.L., 1998, Restoring Streams in Cities: A Guide for Planners, Policymakers, and Citizens. Island Press, Covelo, California, 423 p.

San José Planning: General Plan: Fact Sheet Employment (revised 2004) $\mathrm{http}: / / \mathrm{www}$. sanjoseca.gov/planning/factsheet/employment.html, (last accessed 03/12/05).

Santa Clara Basin Watershed Management Initiative, 2003, Watershed Management Plan: Volume One: Watershed Characteristics Report Unabridged, Chapter 7: Natural Setting, $198 \mathrm{p}$.

Santa Clara County General Plan Book A, 1994, County of Santa Clara Planning Department, San José, California, $280 \mathrm{p}$.

Santa Clara Valley Water District, 1999, Watershed Study Background, Chapter 2, $02 / 19 / 99$.

2001, Santa Clara Valley Water District Groundwater Management Plan, 75 p.

2002a, Water History Teacher's Activity Guide: Timeline of the history of water in Santa Clara County, $62 \mathrm{p}$. 
http://www.valleywater.org/For_Teachers_and_Students/Teaching_materials/Wat er_history_teachers_guide/_Water_history_timeline.shtm, (last accessed $02 / 14 / 05)$.

2002b, Lower Peninsula Watershed: Fast Facts, http://www.valleywater.org/Water/Watersheds_streams_and_floods/Watershed_i nfo_\&_projects/Lower_Peninsula/Lower_Peninsula_fast_facts.shtm, (last accessed 03/20/05).

2004a, Adobe Creek Upper Reach 5 Restoration Project, 14 p.

http://www.pajarowatershed.com/AdobeAnnex/2004-06-25_ProjectPlan.pdf, (last accessed 08/17/09).

2004b, ECR Permanente Subsidence: Map of North County: 1934-1967. http://www.valleywater.org/media/pdf/Permanente/ECR_Permanente_Subsidence .pdf, (last accessed 01/21/04).

2005, Lower Peninsula Watershed Stewardship Plan: Chapter 9 Adobe Creek Watershed Management Unit, $80 \mathrm{p}$.

2007a, Adobe Creek Upper Reach 5 Project Draft Engineer's Report, 59 p.

2007b, Neighborhood Notice Adobe Creek Sediment Removal.

2007c, Public Records Request, 06/07/07.

2007d, Library files.

2008, Neighborhood Notice Adobe Creek Sediment Removal.

Sen, D., 2005, Memorandum: Adobe Creek Geomorphic Survey Draft, 11 p.

Silva, J., 2002, Santa Clara County: California's Historic Silicon Valley

http://www.cr.nps.gov/nr/travel/santaclara/text.htm, (last accessed 02/14/05).

Sloan, D., 2006, The geology of the San Francisco Bay region, Berkeley, University of California Press, 337 p.

Snow, D., 2003, Town of Los Altos Hills California:Town Facts (modified 9/9/2003) http://www.losaltoshills.ca.gov/town-facts, (last accessed 02/14/05).

Sowers, J.M., 2004, Creek and Watershed Map of Palo Alto and Vicinity: Oakland Museum of California, Oakland, CA, 1:25 800 scale, 1 sheet. 
Spitalere, P., 2002, Woz Way Paper: Remembering Lexington and Alma http://www2.sjsu.edu/depts/commstudies/woz/paper2.html, (last accessed $02 / 14 / 05)$.

Stanley, R.G., Jachens, R.C., Lillis, P.G., McLaughlin, R.J., Kvenvoldn, K.A., Hostettler, F.D., McDougall, K.A., and Magoon, L.B., 2002, Subsurface and petroleum geology of the southwestern Santa Clara Valley ("Silicon Valley"), California: U.S. Geological Survey Professional Paper 1663, 56 p.

Stoffer, P.W., 2005, The San Andreas Fault In The San Francisco Bay Area, California: A Geology Fieldtrip Guidebook To Selected Stops On Public Lands: U.S. Geological Survey Open-File Report 2005-1127, 133 p.

Thompson and West, 1973, New historical atlas of Santa Clara Co. California illustrated. San José, CA: Smith and McKay, Reprint of 1876 ed. published by Thompson and West, San Francisco, 110 p.

U.S. Geological Survey, 1899, Palo Alto Quadrangle, California: 15 minute series, Washington D.C., scale 1:62 500, 1 sheet http://sunsite2.berkeley.edu:8088/xdlib//maps/brk00010.00000018.xml, (last accessed 08/17/09).

1961, Cupertino, California: 7.5 minute series, Washington D.C., scale $1: 24000,1$ sheet.

1961, Mindego Hill, California: 7.5 minute series, Washington D.C., scale $1: 24000,1$ sheet.

1961, Mountain View, California: 7.5 minute series, Washington D.C., scale $1: 24000,1$ sheet.

1961, Palo Alto, California: 7.5 minute series, Washington D.C., scale 1:24 000, 1 sheet.

Westdahl, F., 1897, Pacific coast resurvey of San Francisco Bay, California, Mountain View to Alviso: Washington, D.C., Rockville, MD: U.S. Coast and Geodetic Survey, National Ocean Service in Santa Clara Valley Water District: Lower Peninsula Watershed Stewardship Plan: Chapter 9 Adobe Creek Watershed Management Unit, 2005.

Wikipedia, 2005a, Los Altos, California-Wikipedia, (modified 03/07/05) http://en.wikipedia.org/wiki/Los_Altos,_California, (last accessed 03/20/05). 
2005b, Los Altos Hills, California-Wikipedia (modified 02/04/05)

http://en.wikipedia.org/wiki/Los_Altos_Hills,_California, (last accessed $02 / 14 / 05)$.

Wilson, S., 2004, West Edith Avenue Bridge Fact Sheet http://www.lahopenspace.com/Adobe5/2004-01-28_EdithBridge.htm, (last accessed 10/17/07). 
APPENDIX A

Longitudinal Profiles 


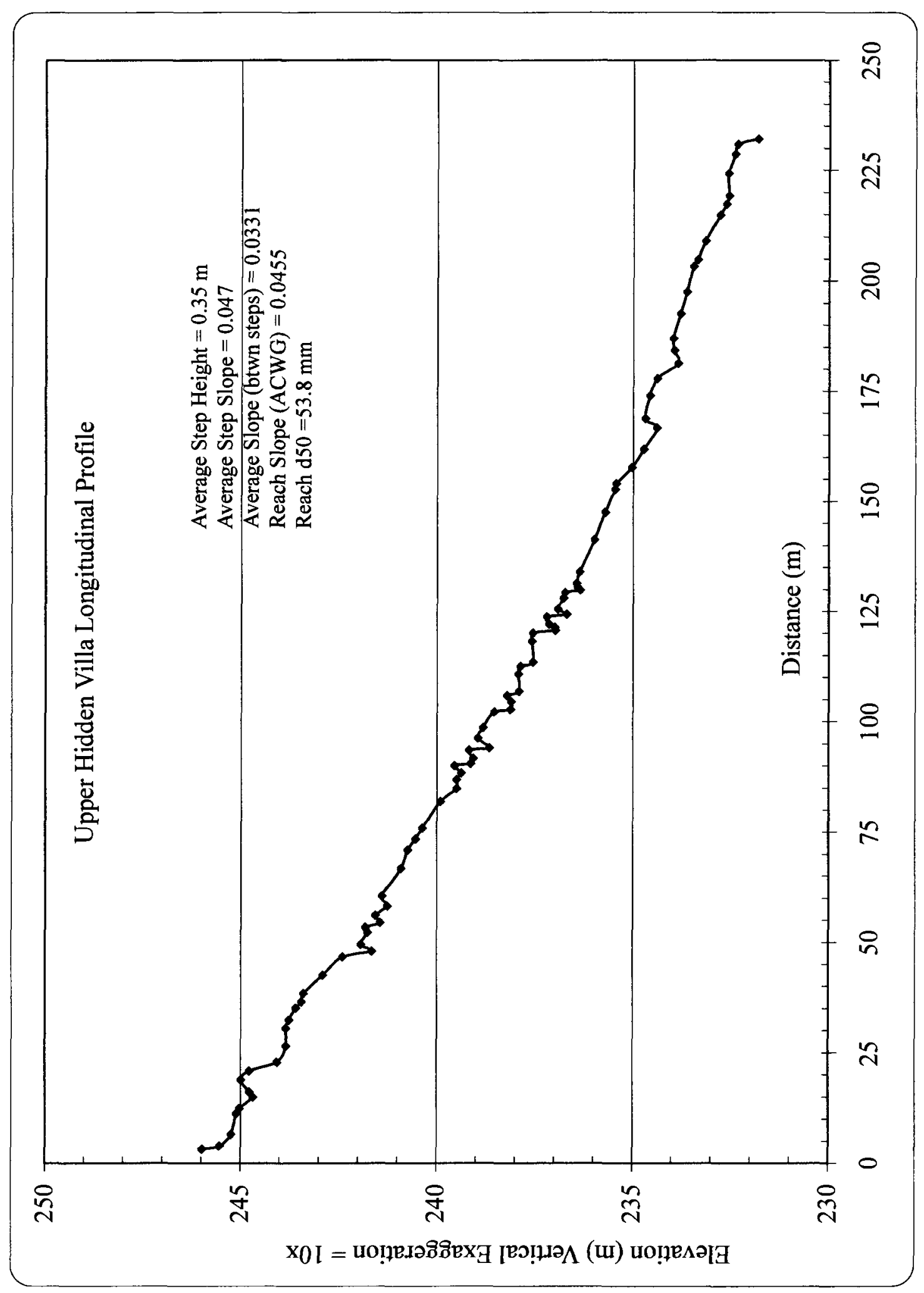




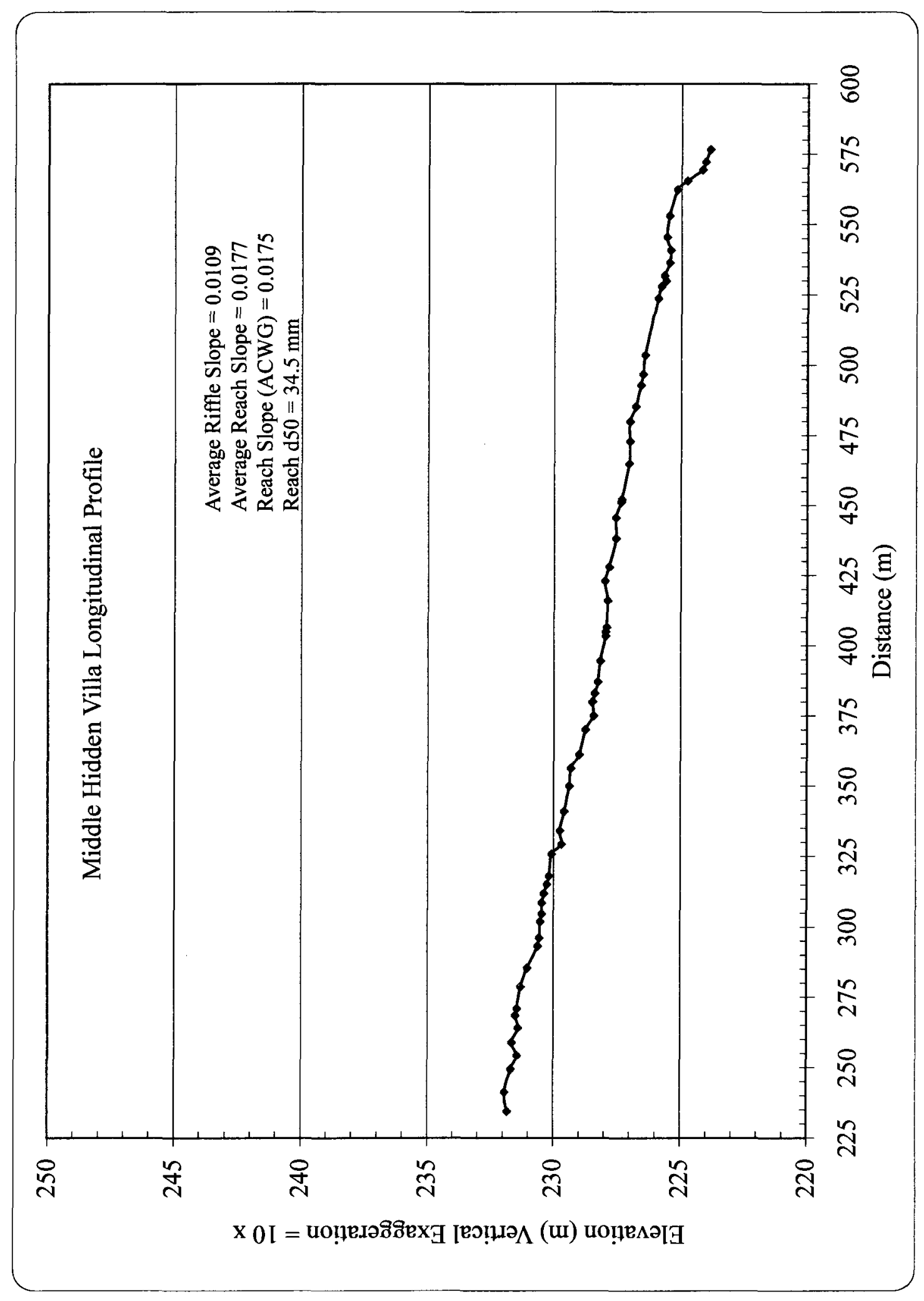




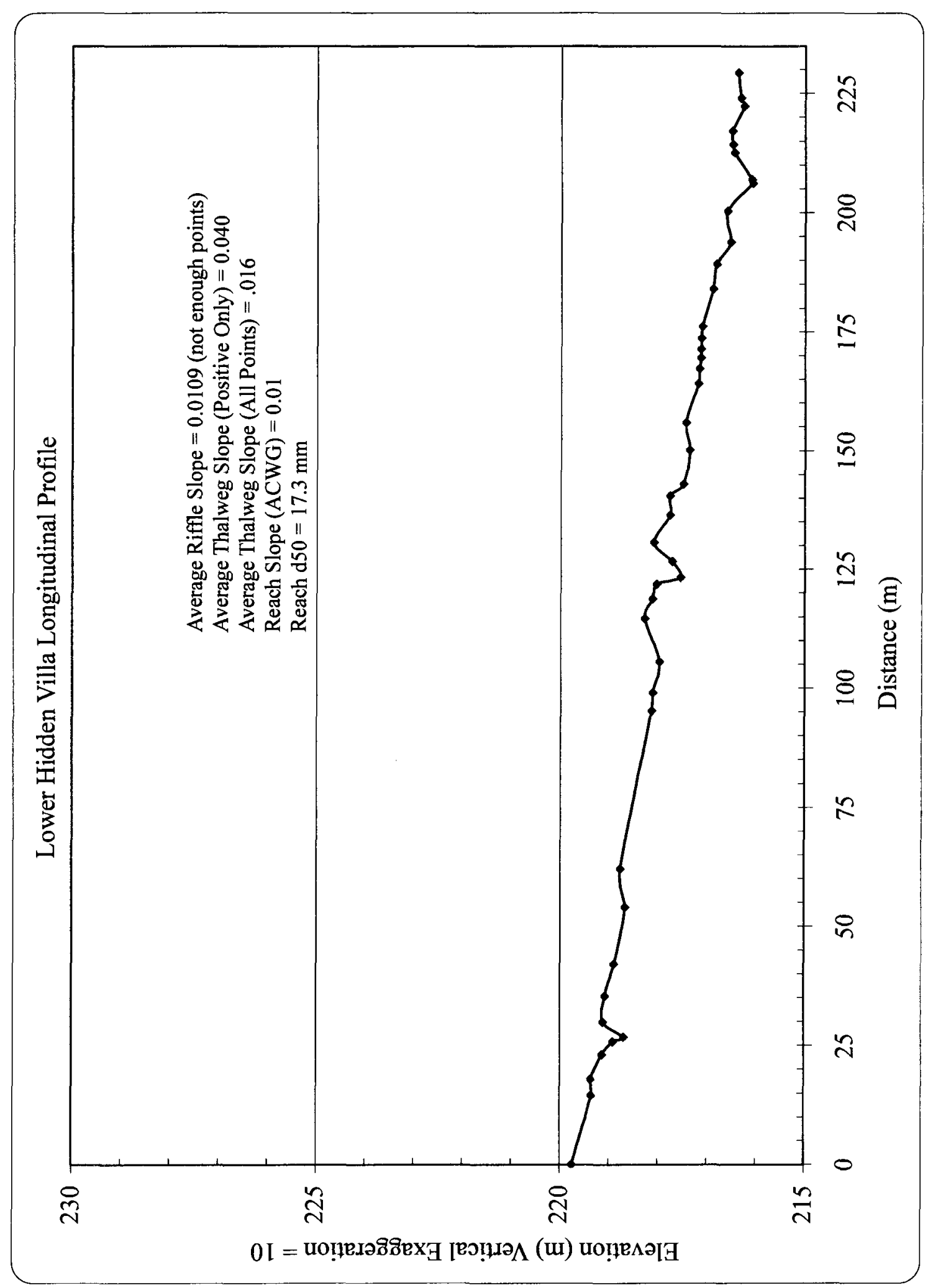




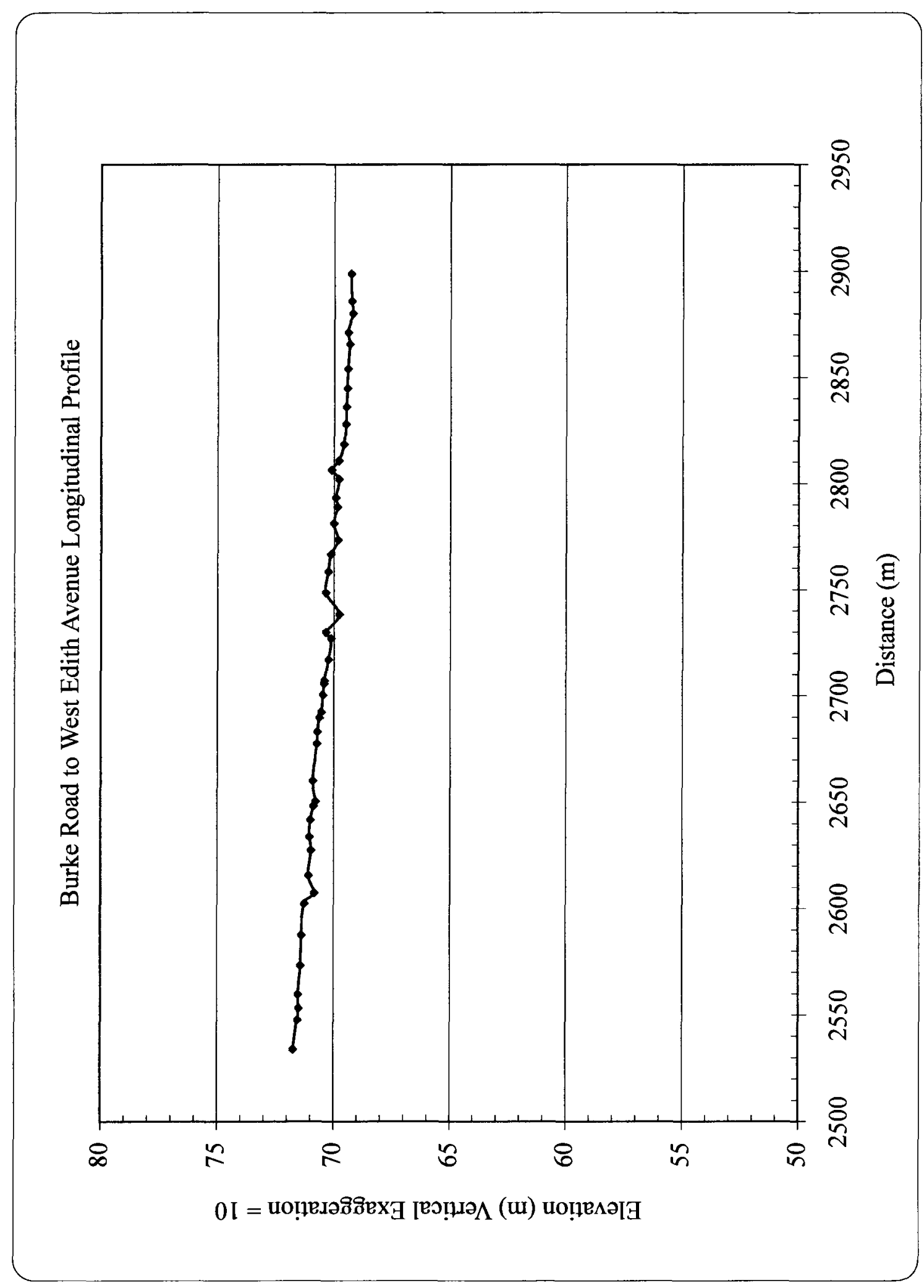




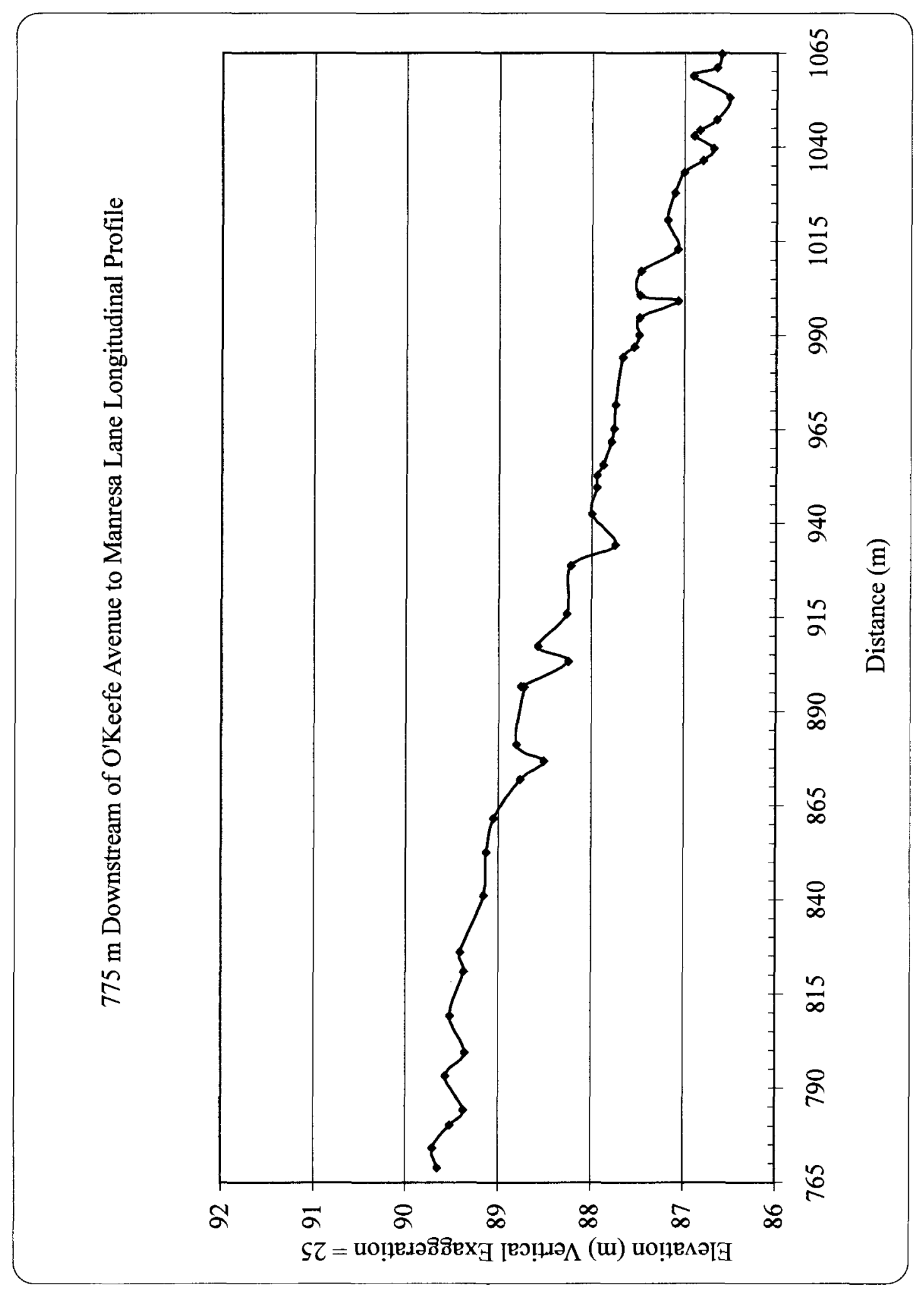




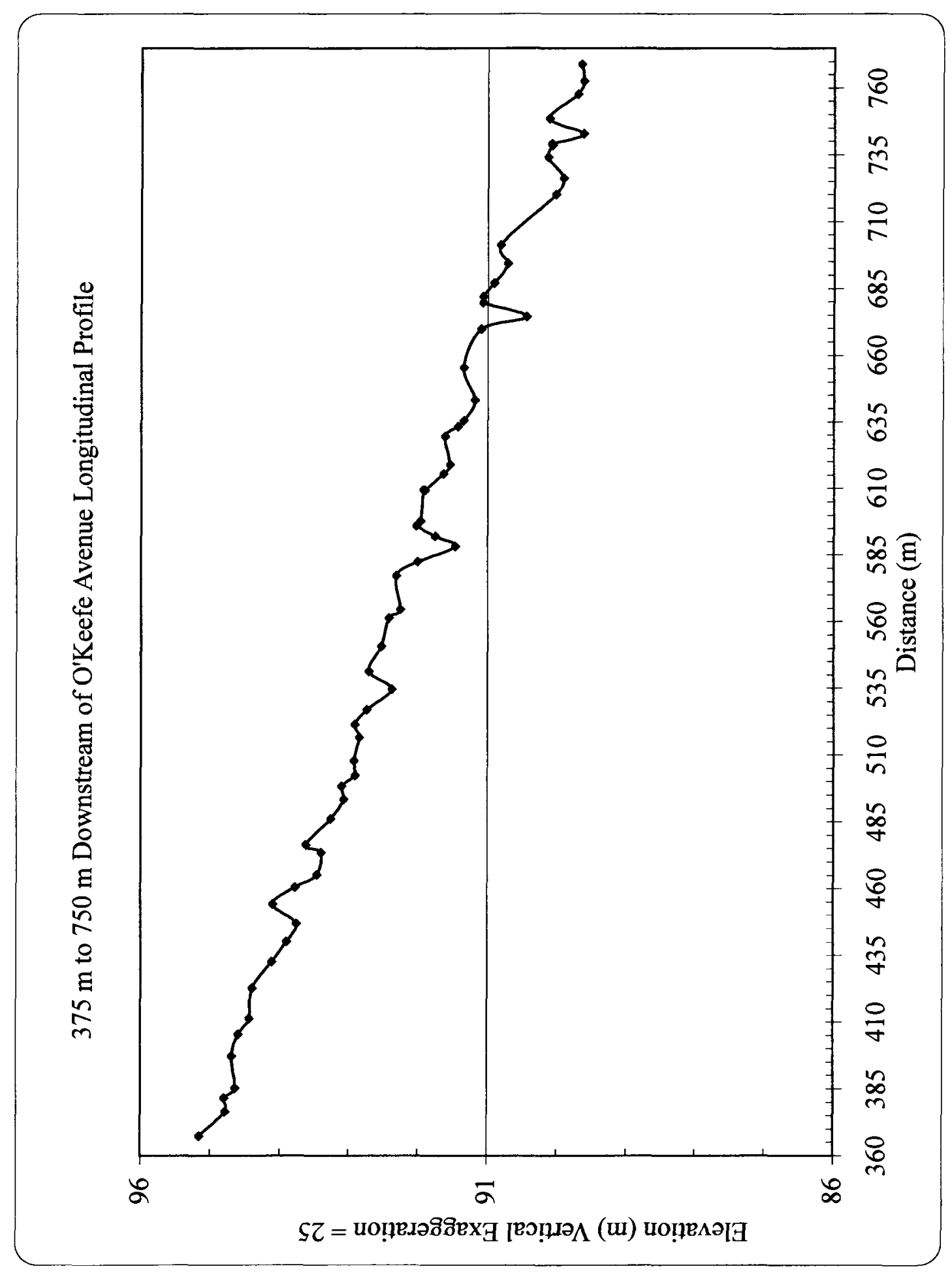




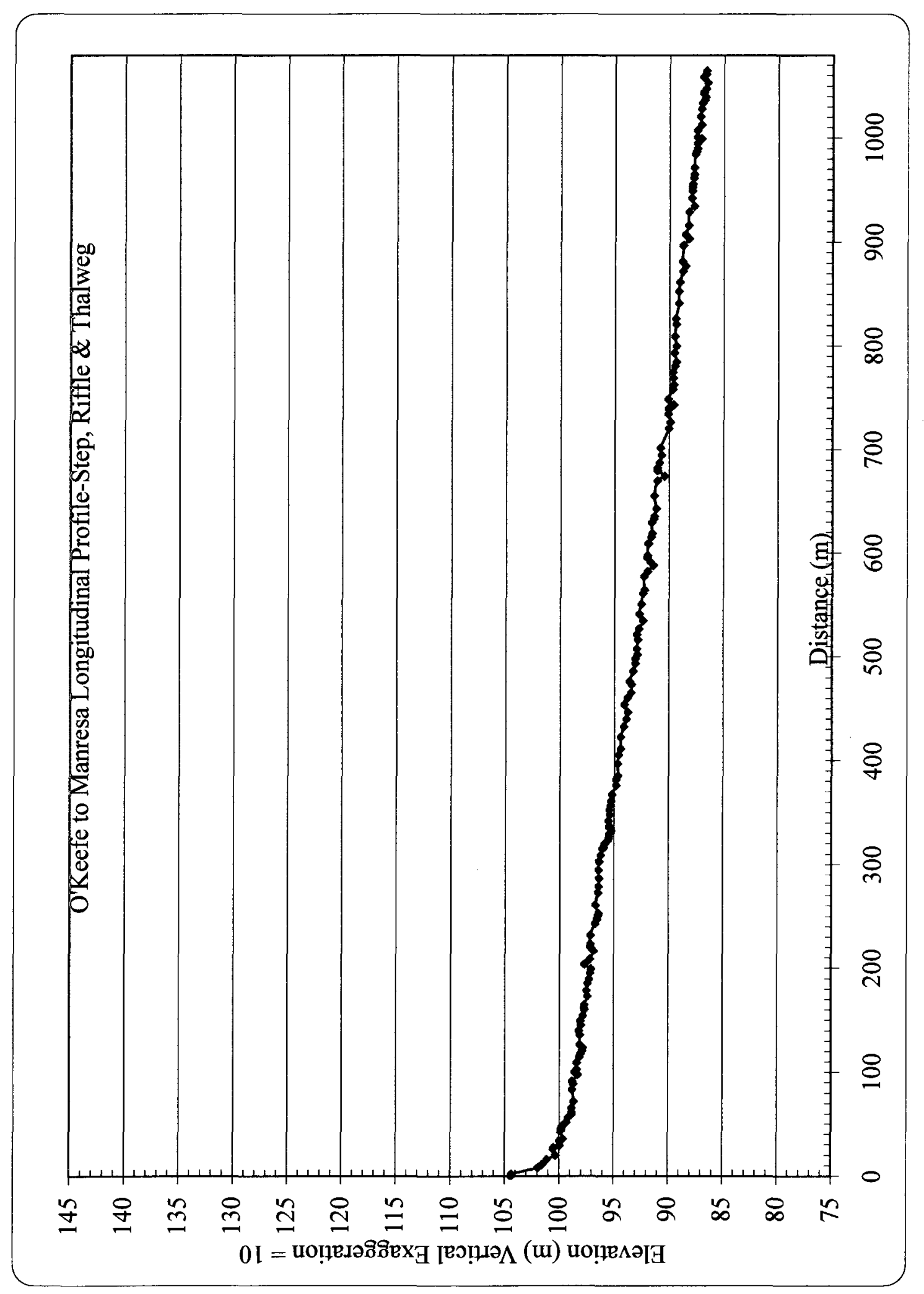




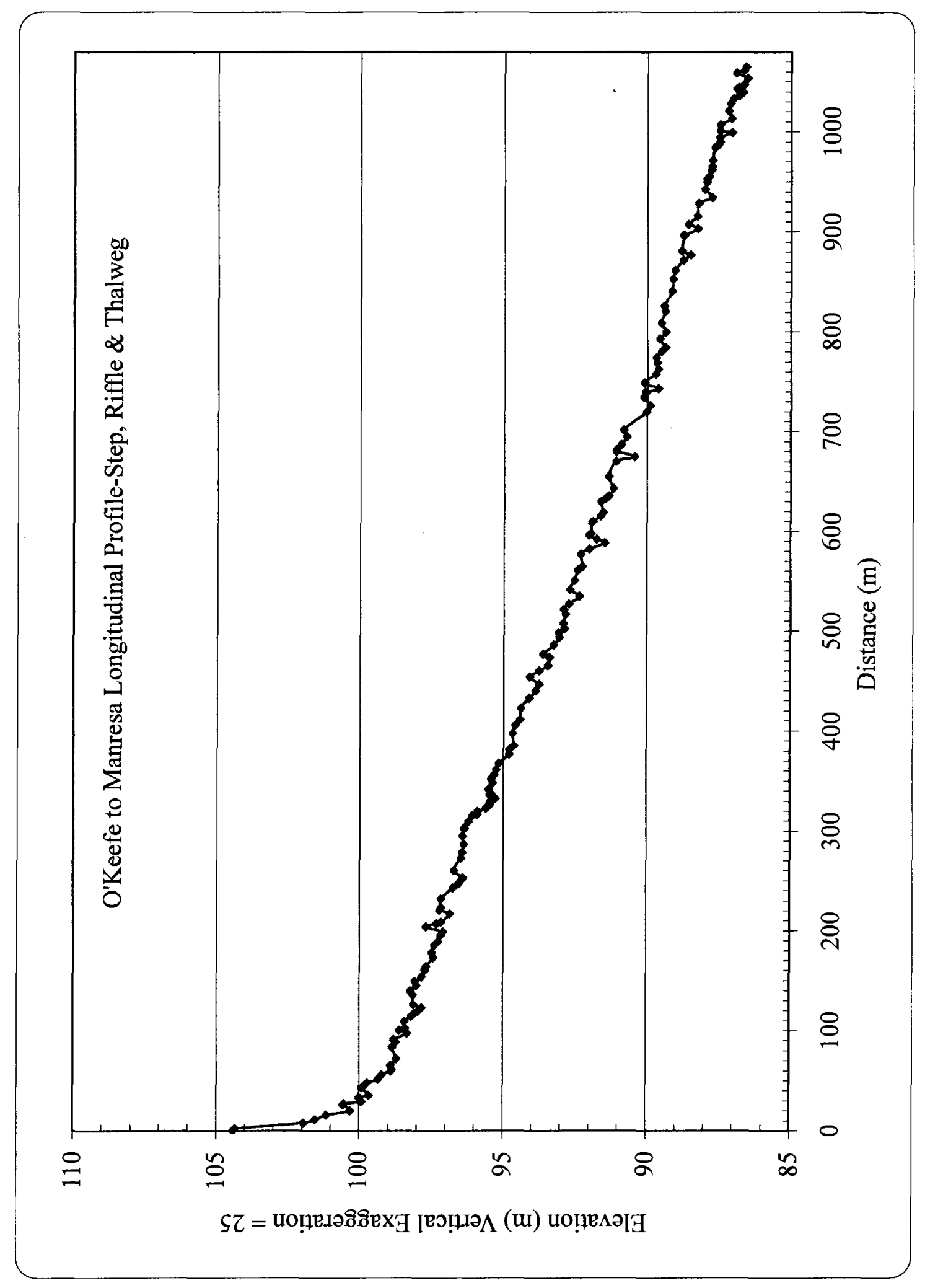




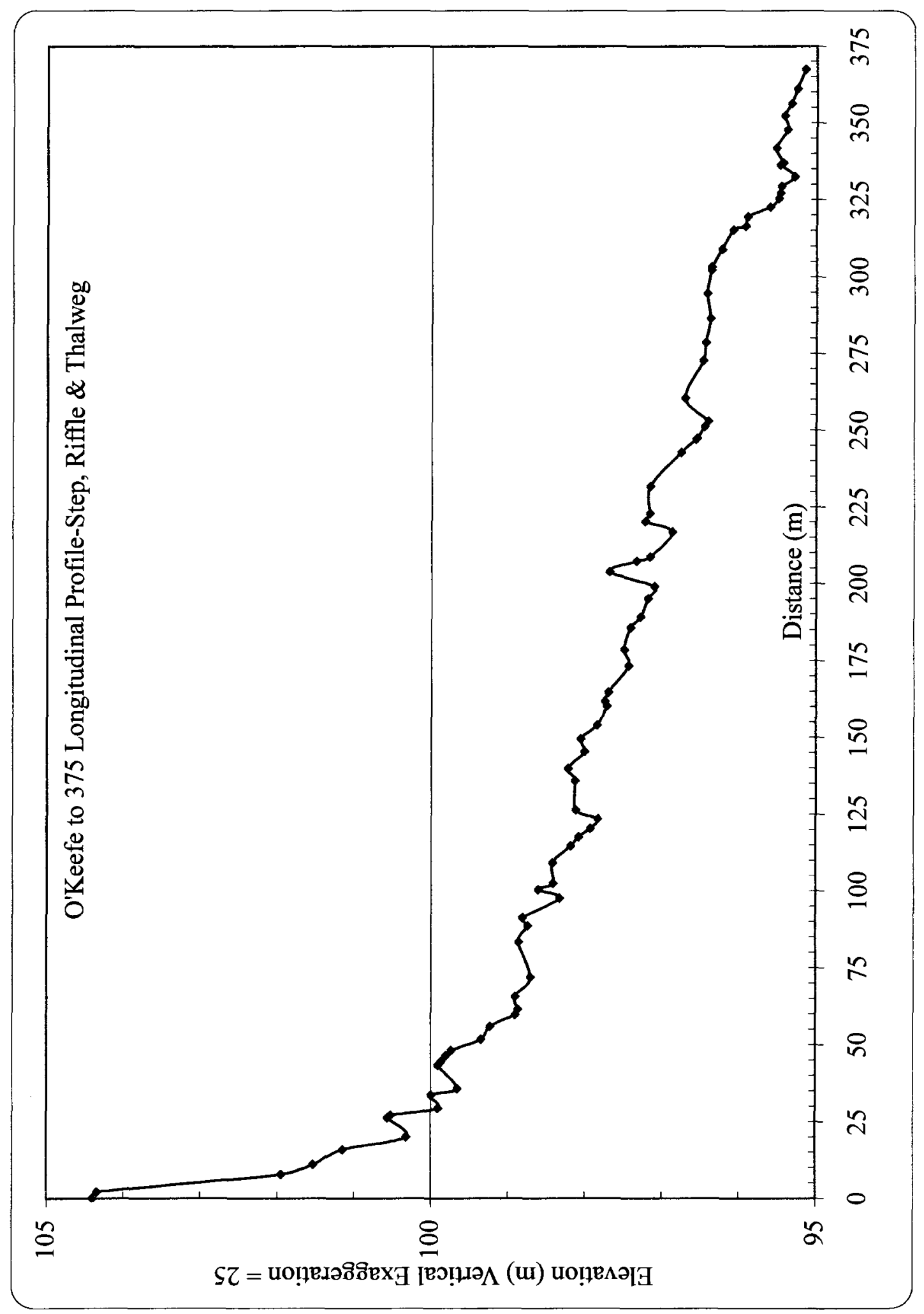




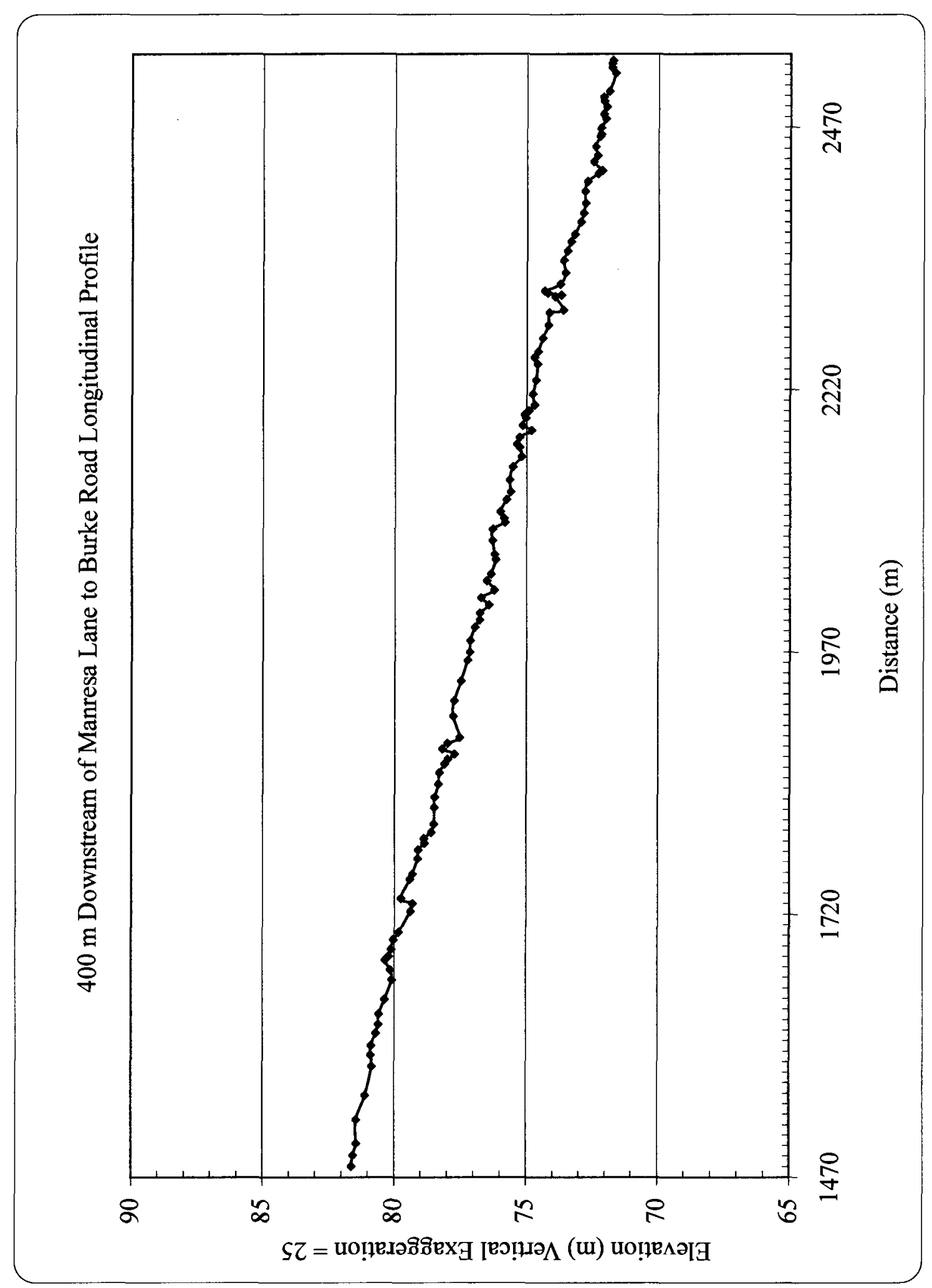




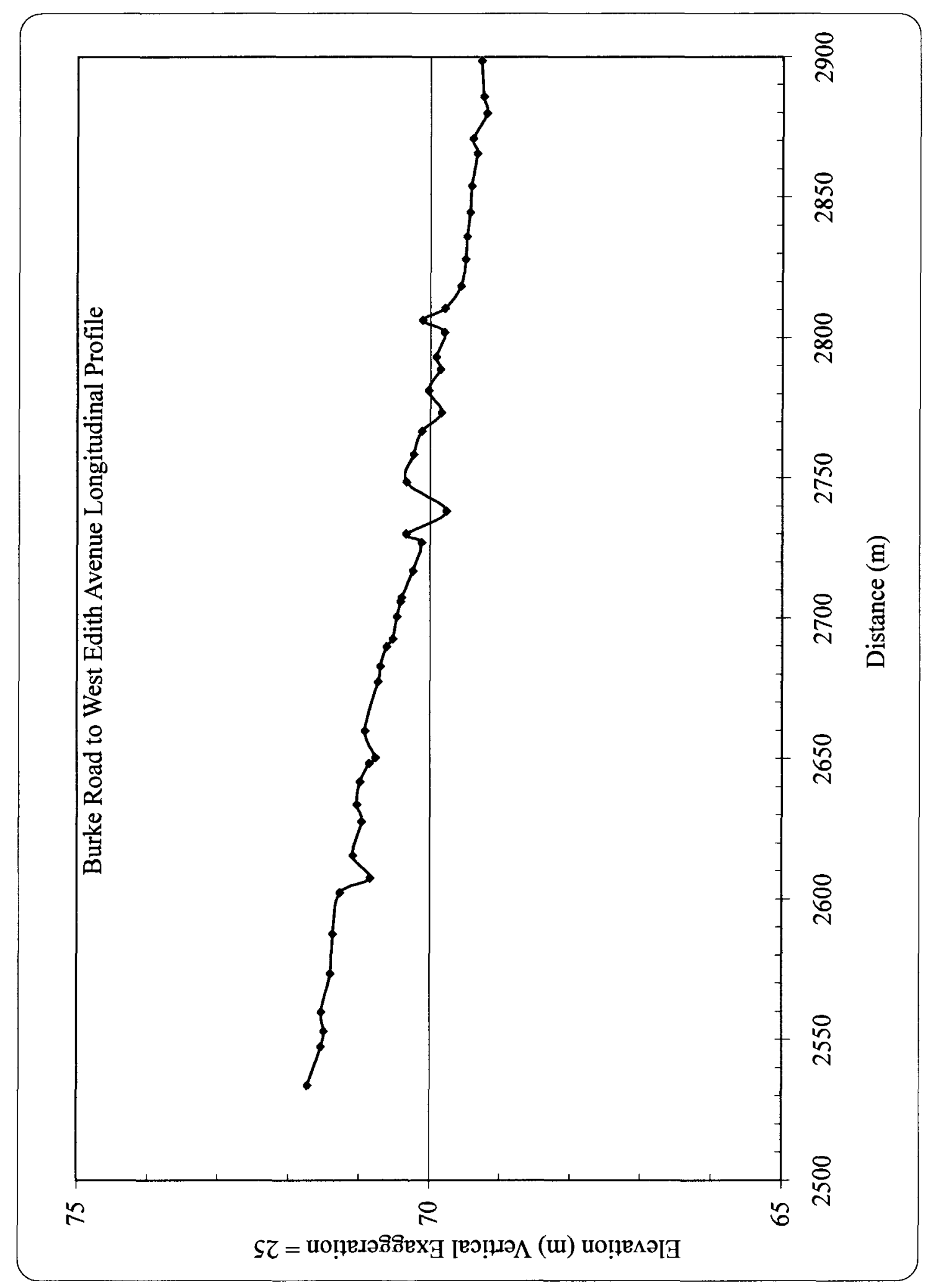




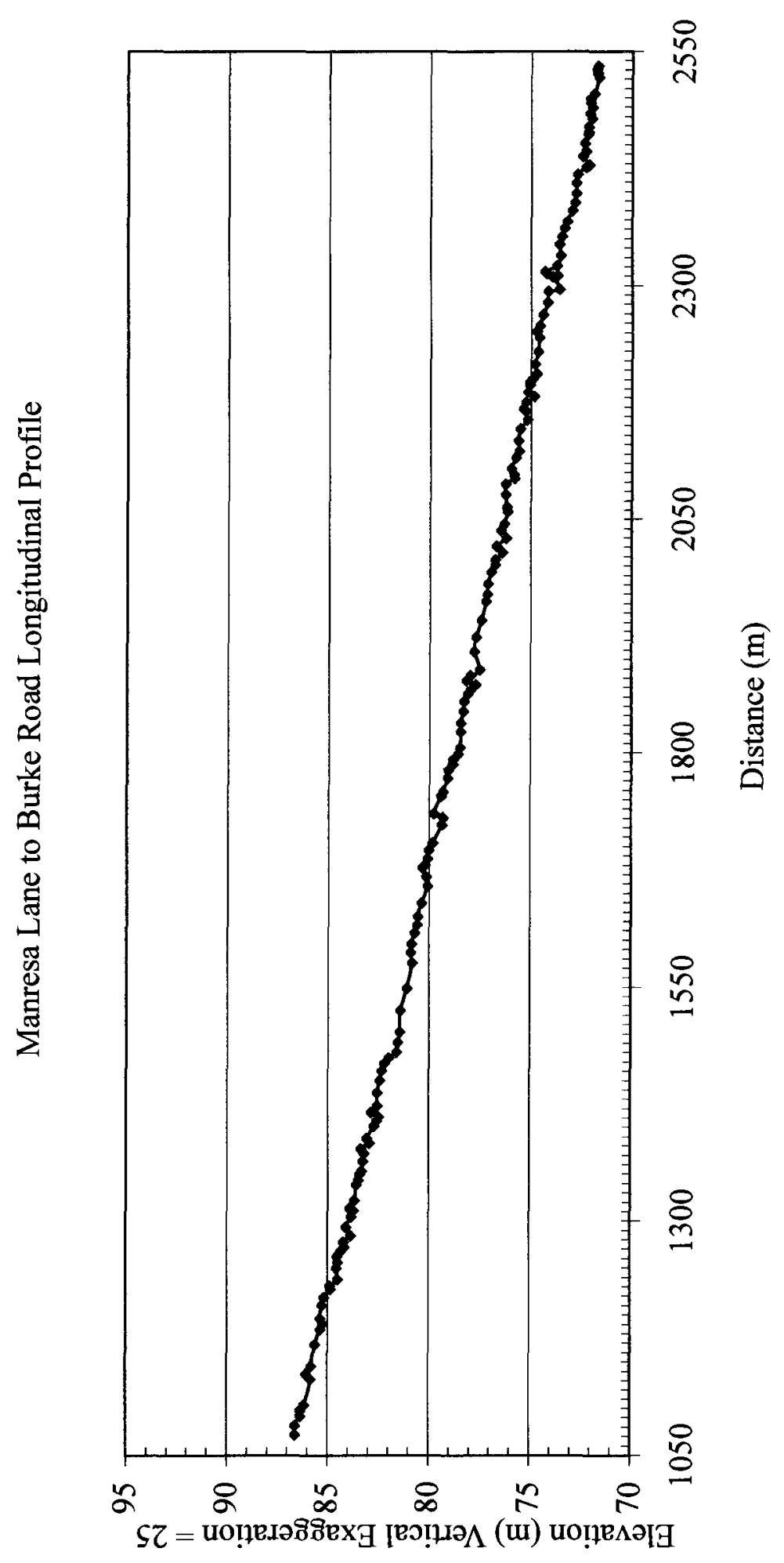




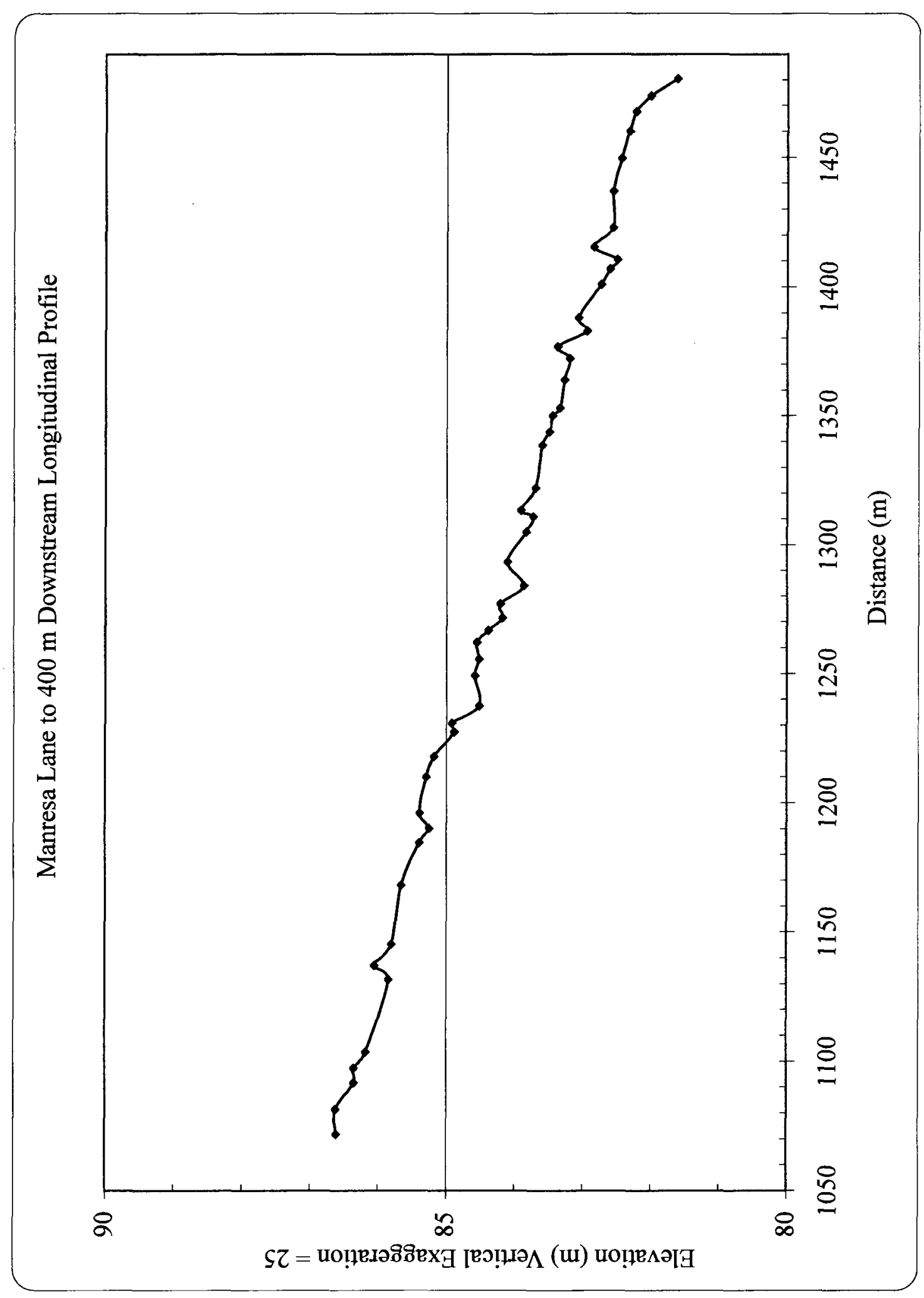


APPENDIX B

Cross-Sections 


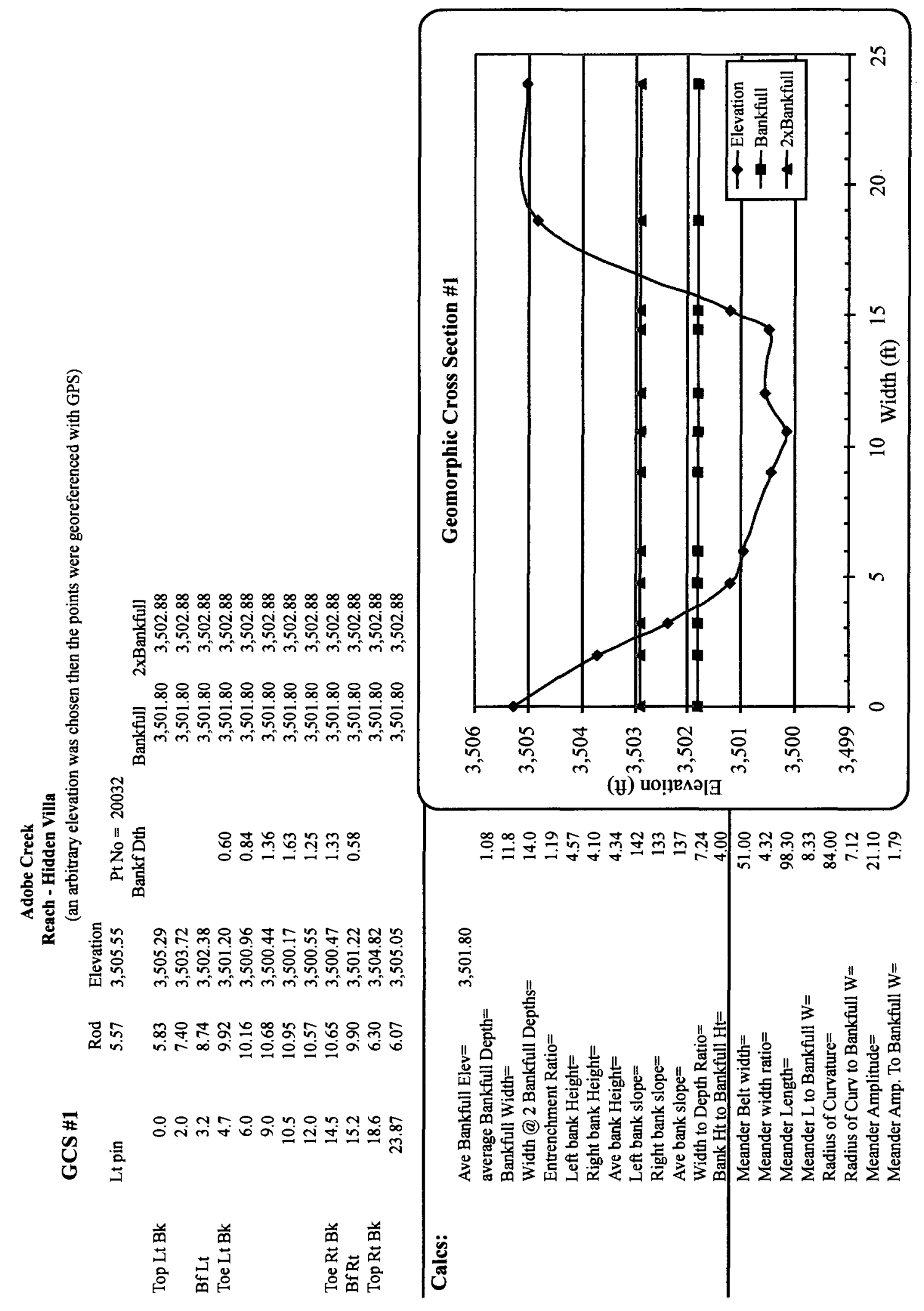




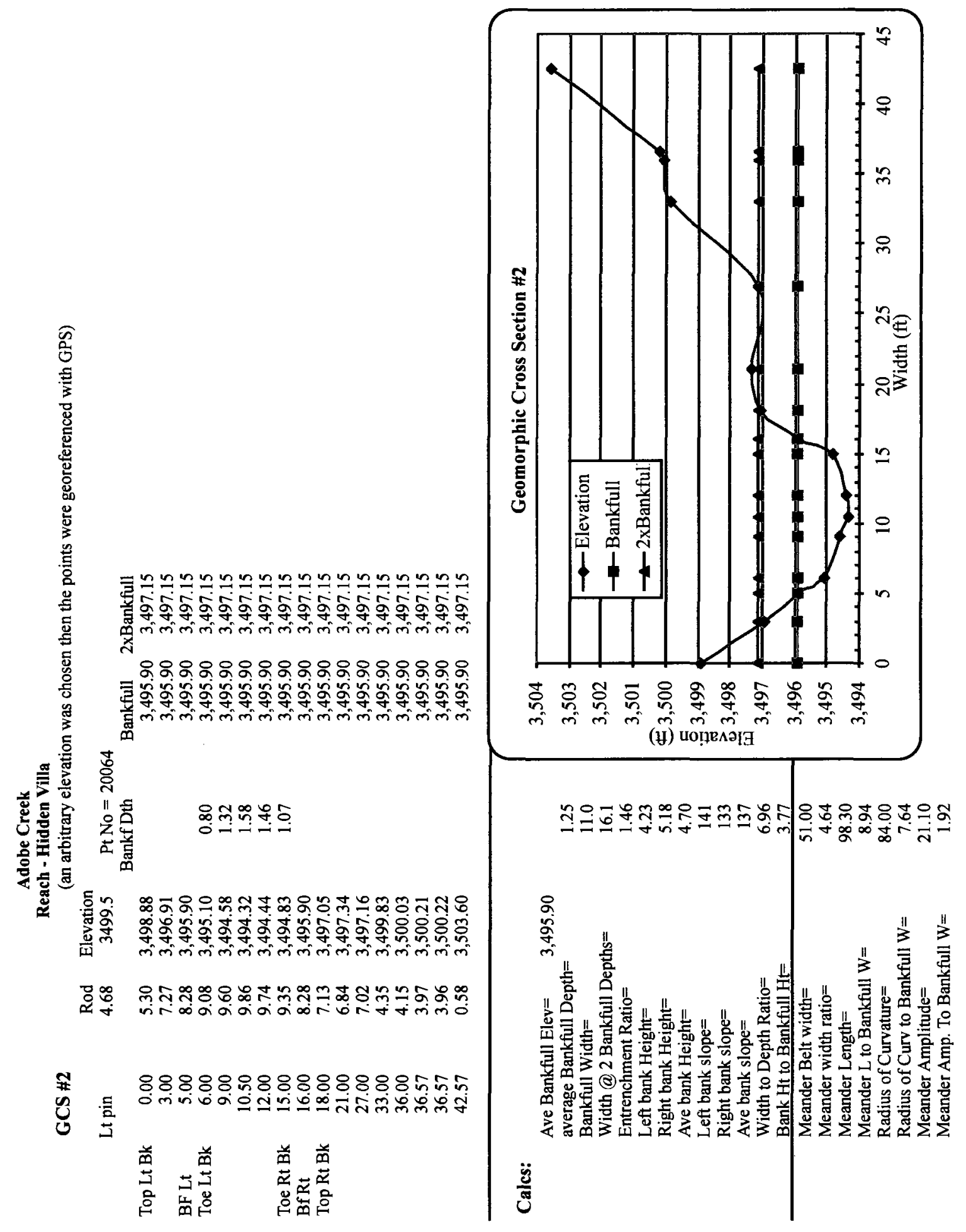




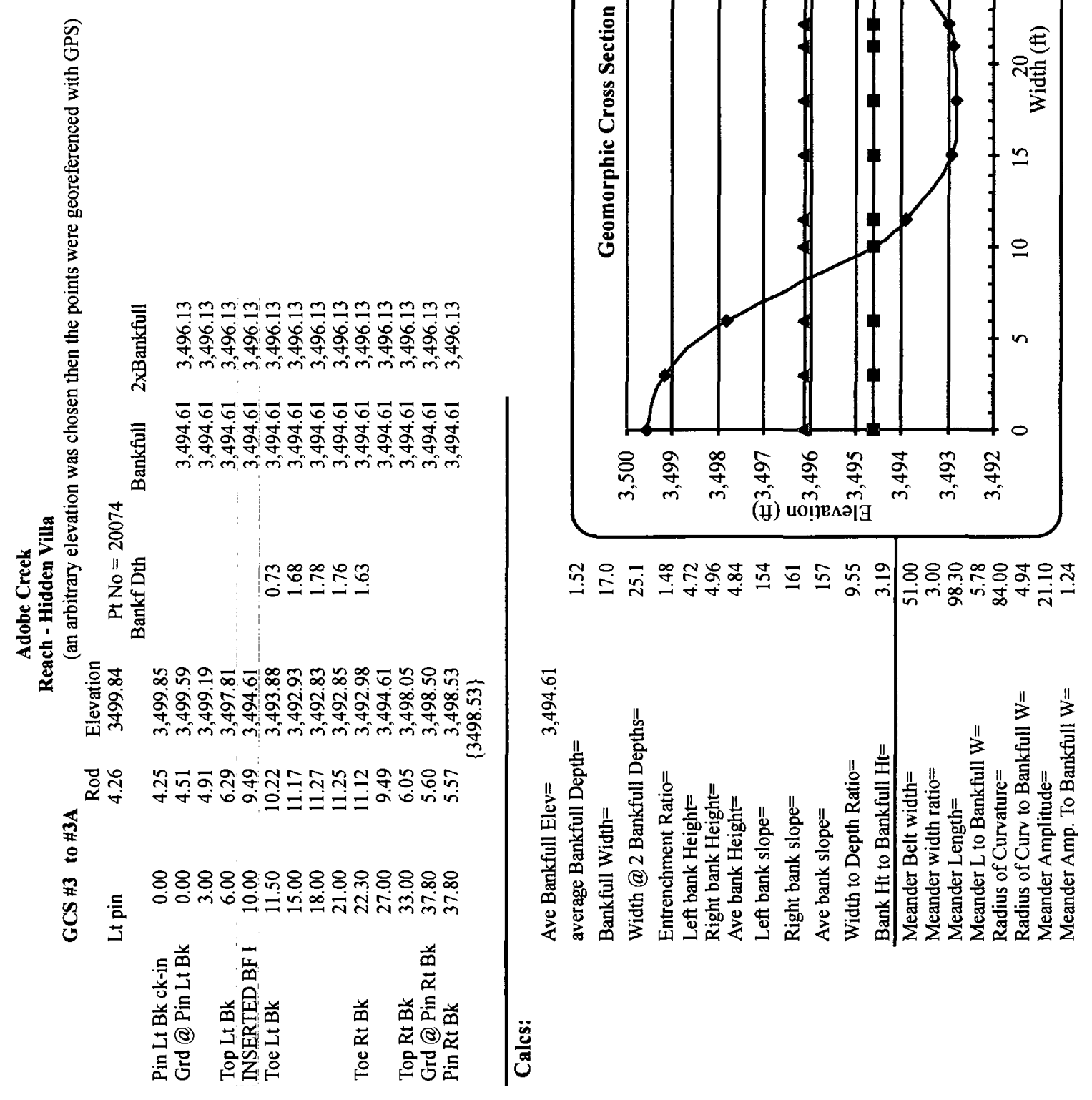



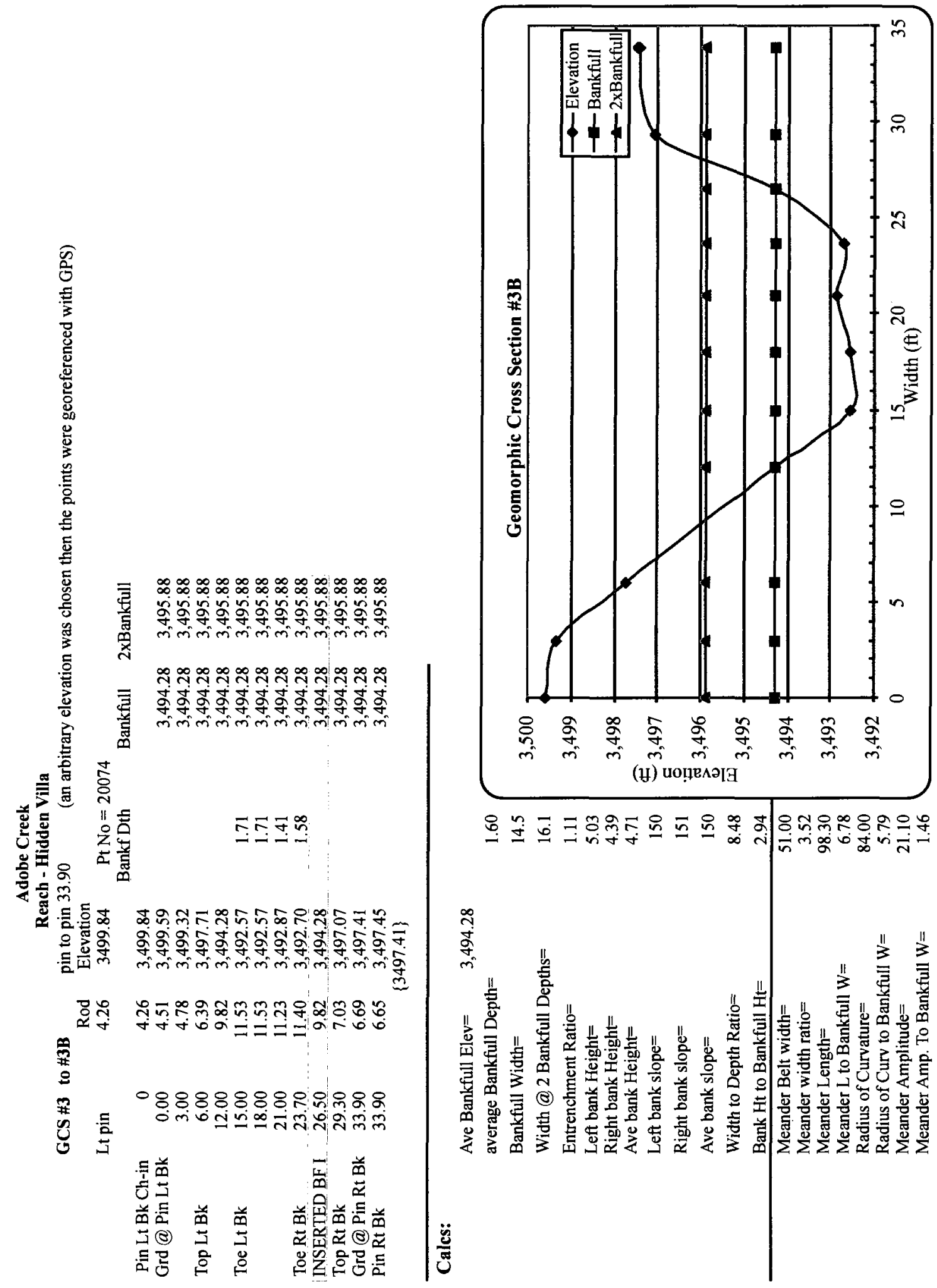


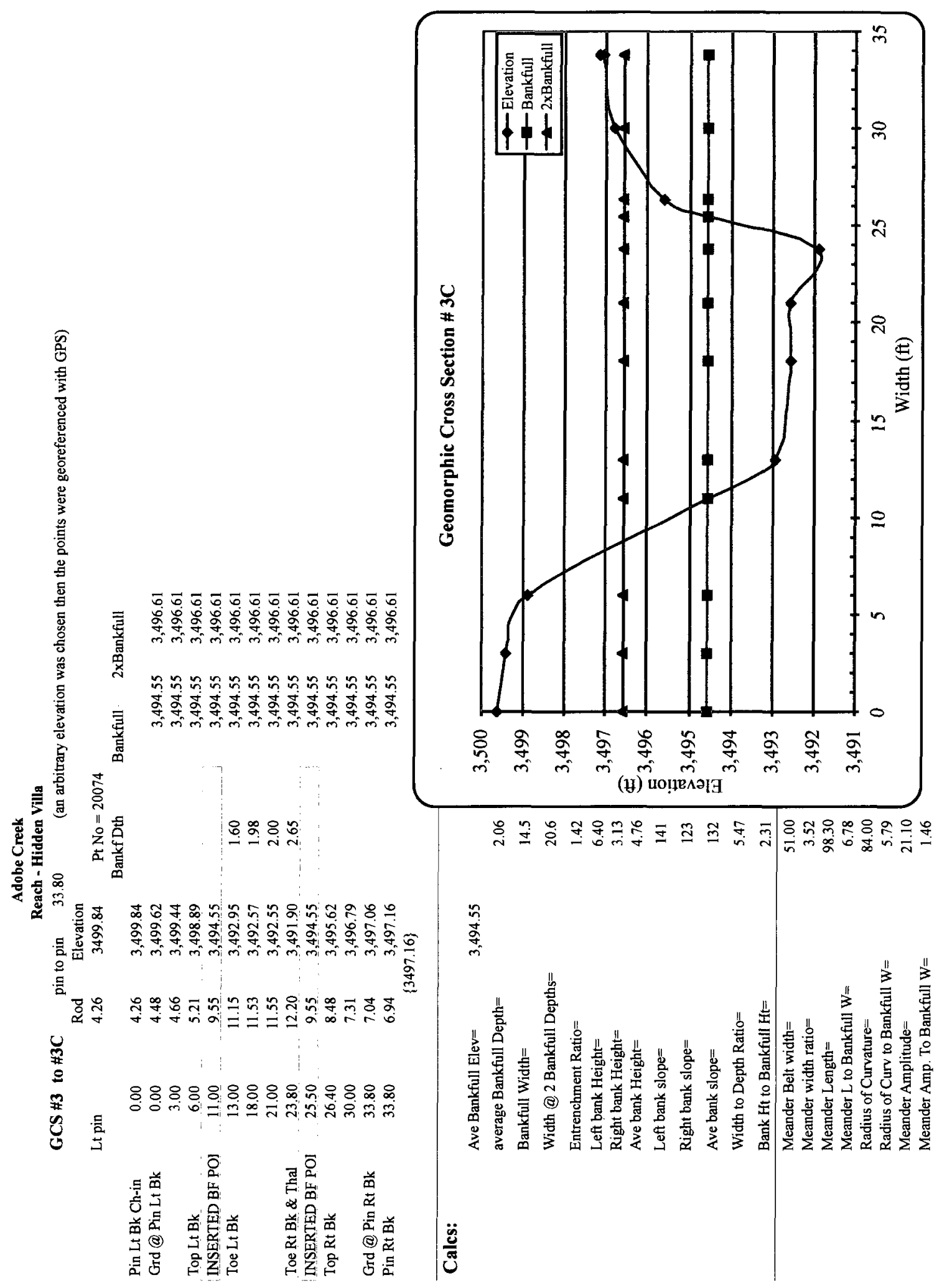




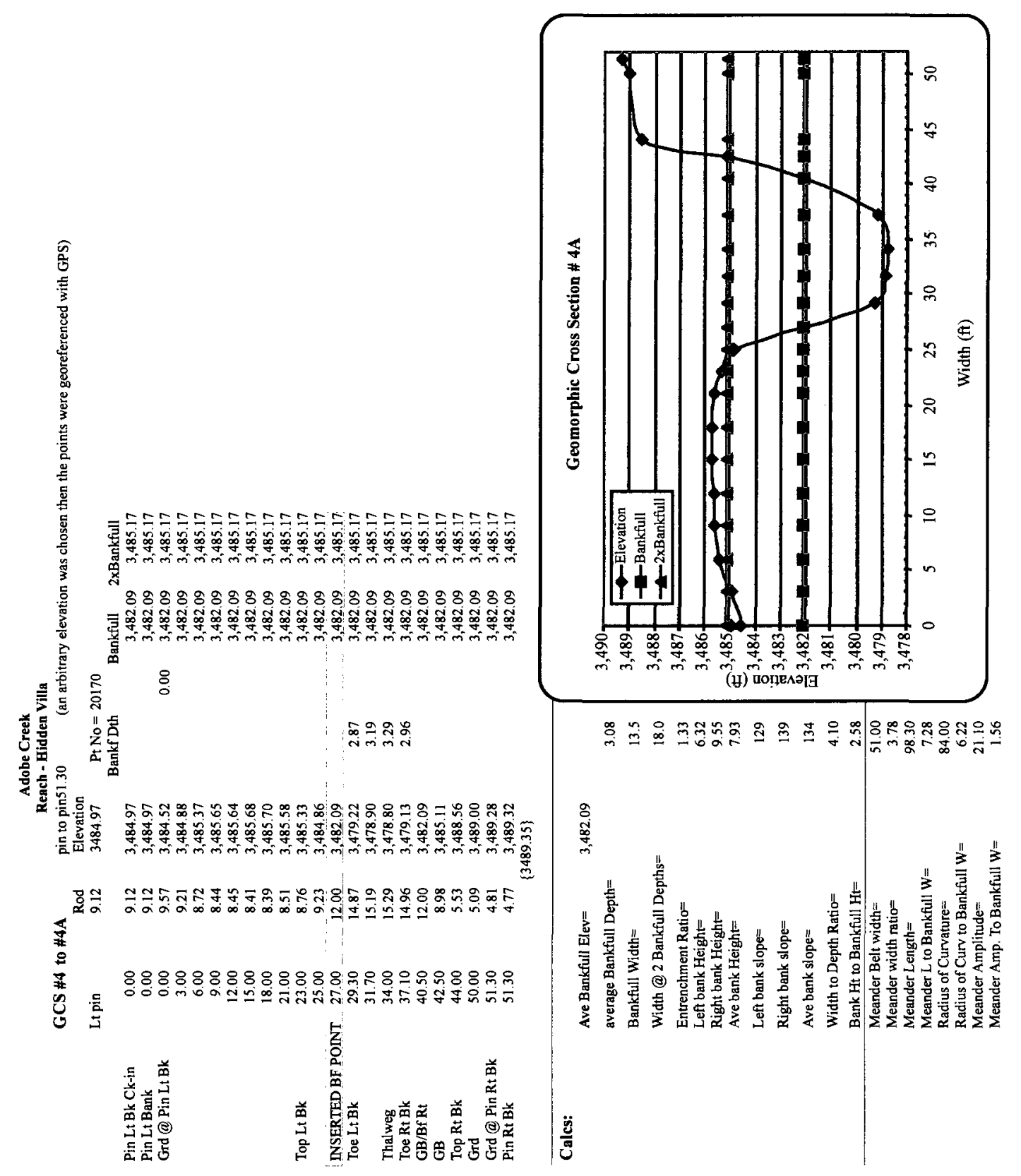




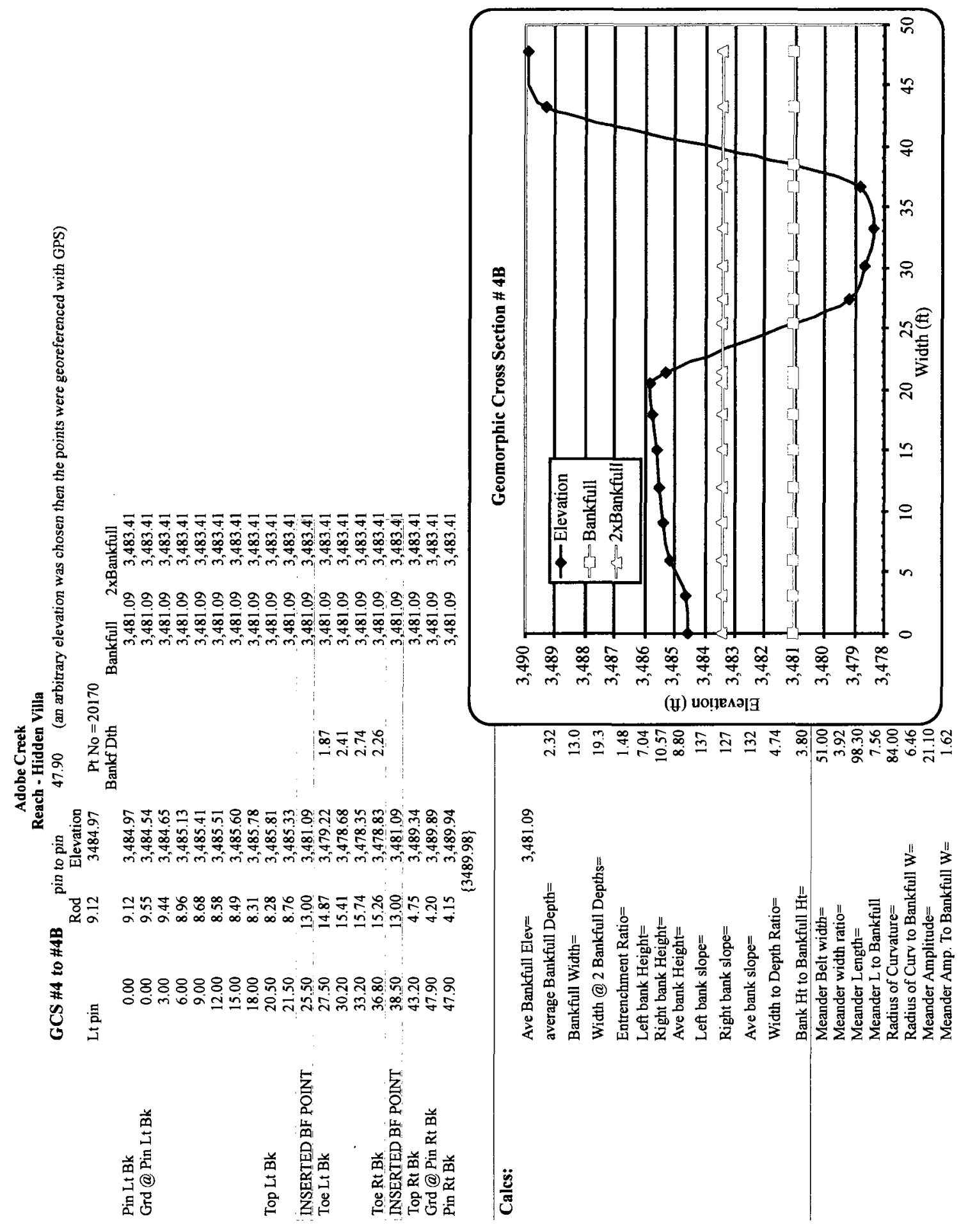




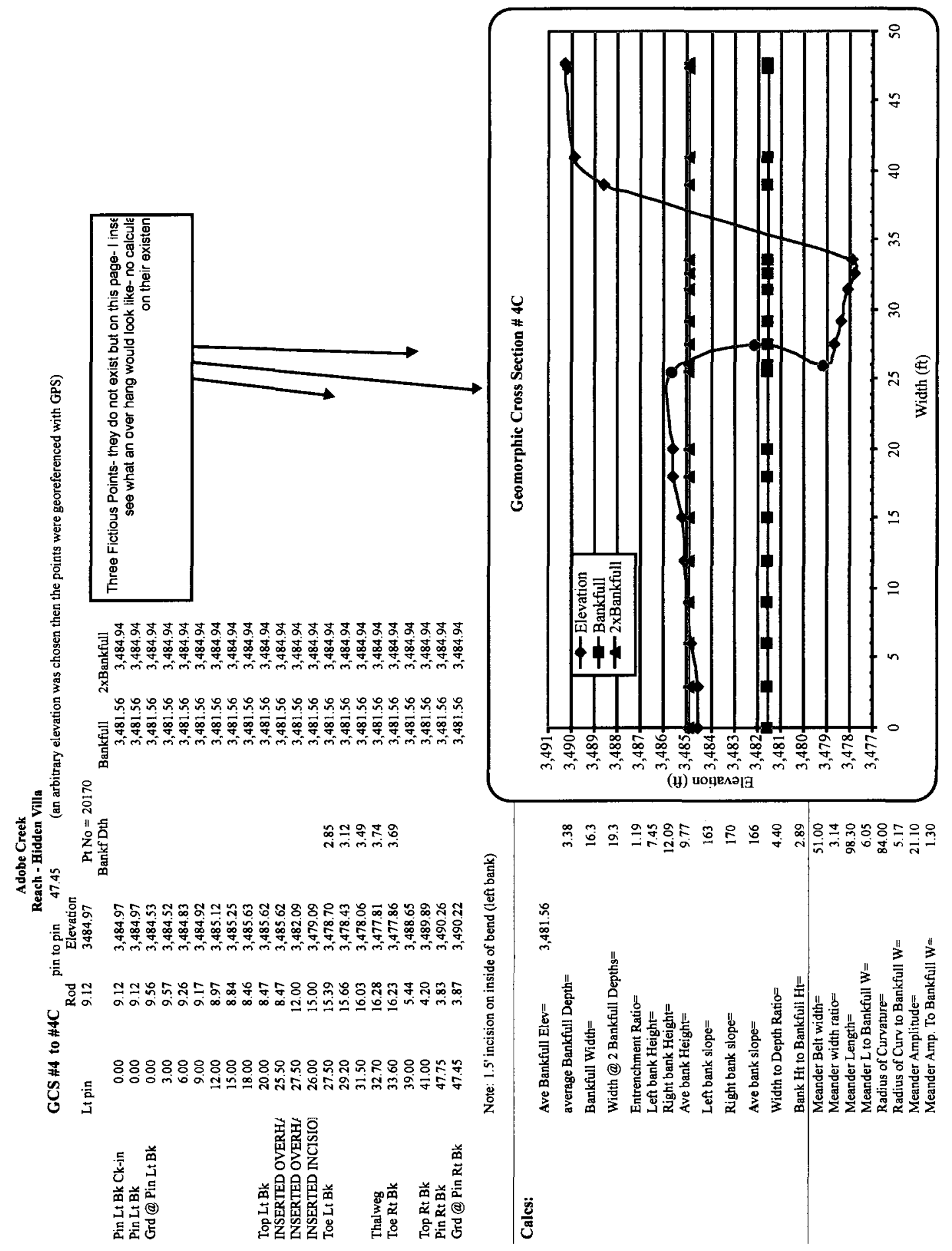




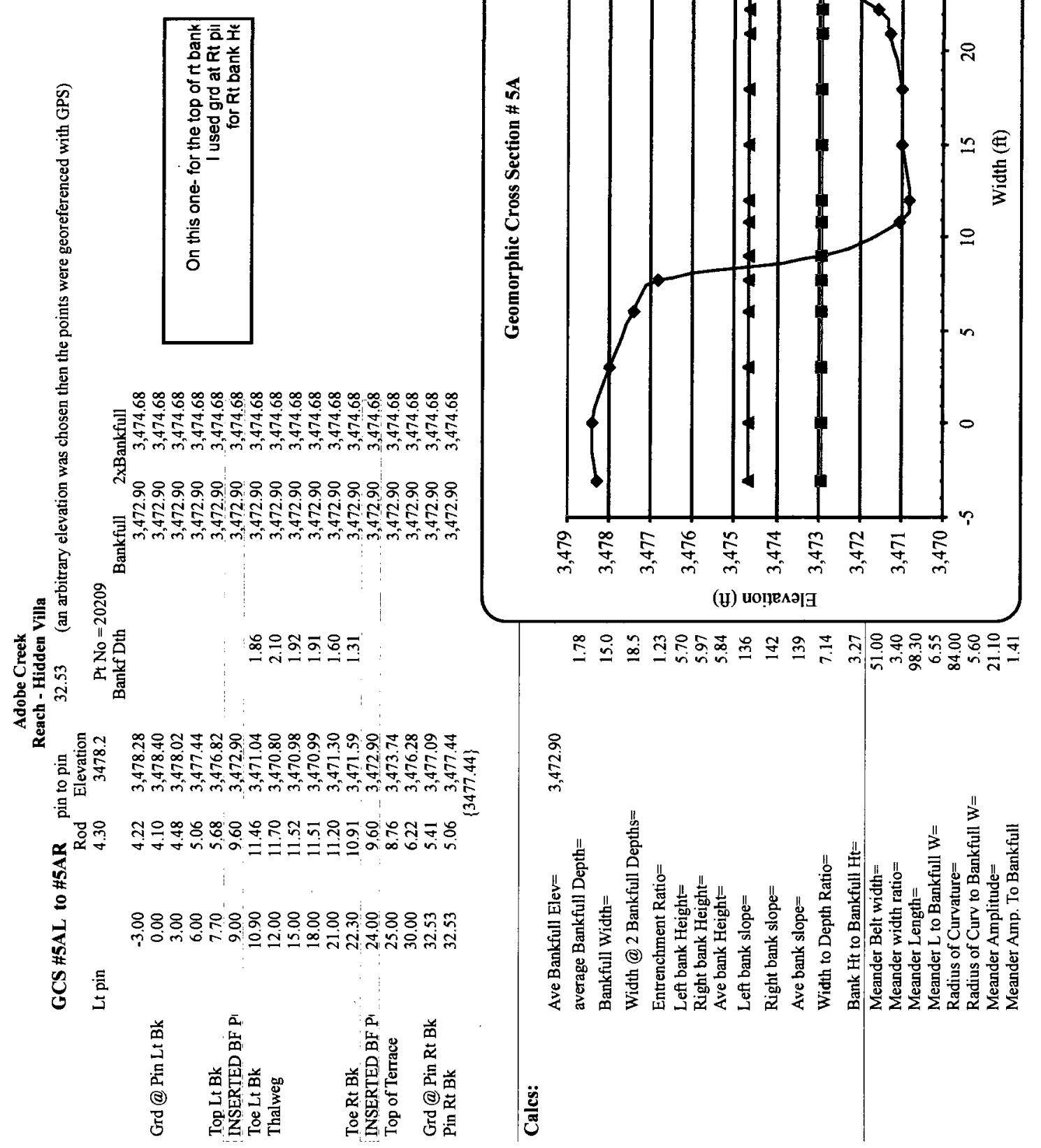




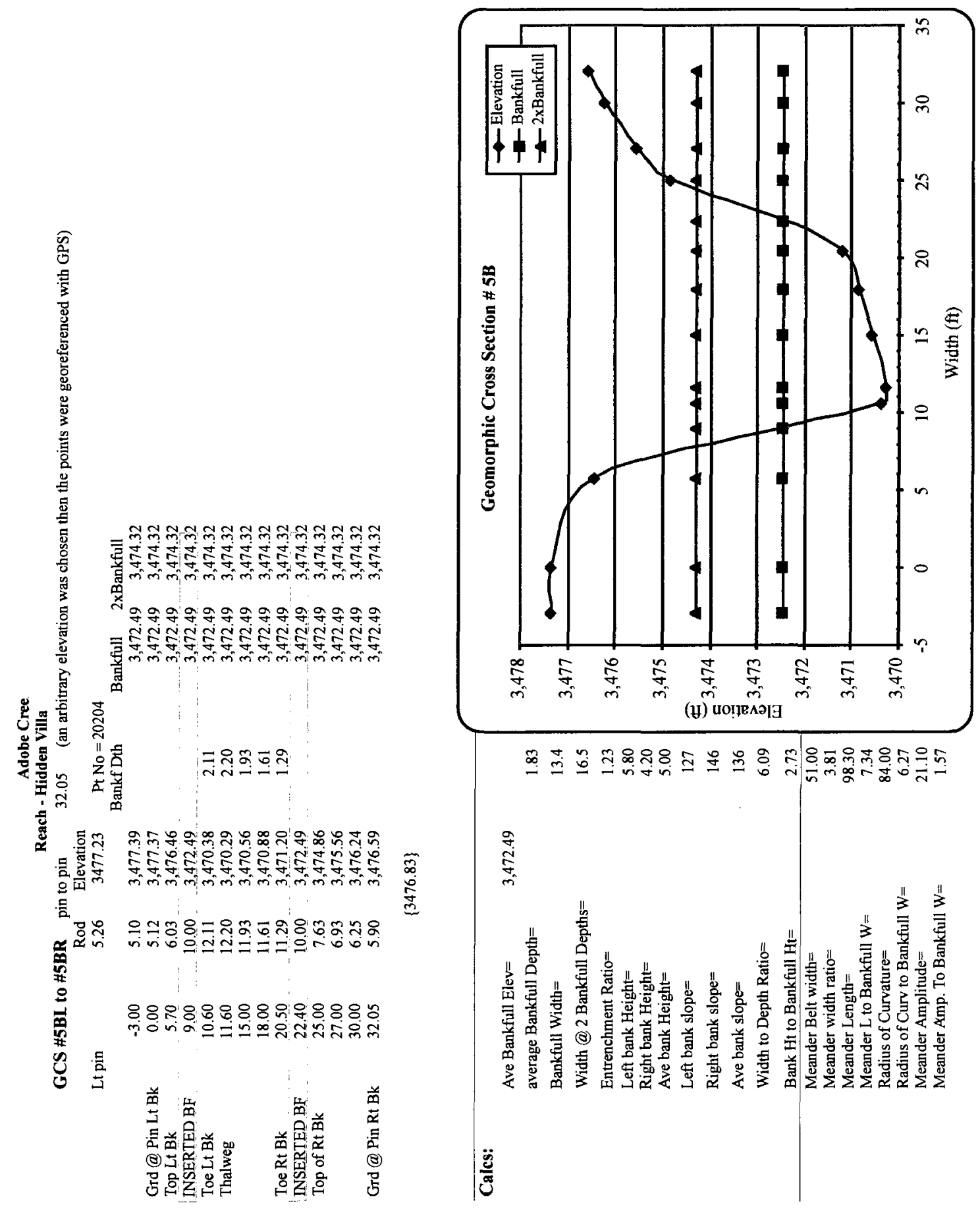




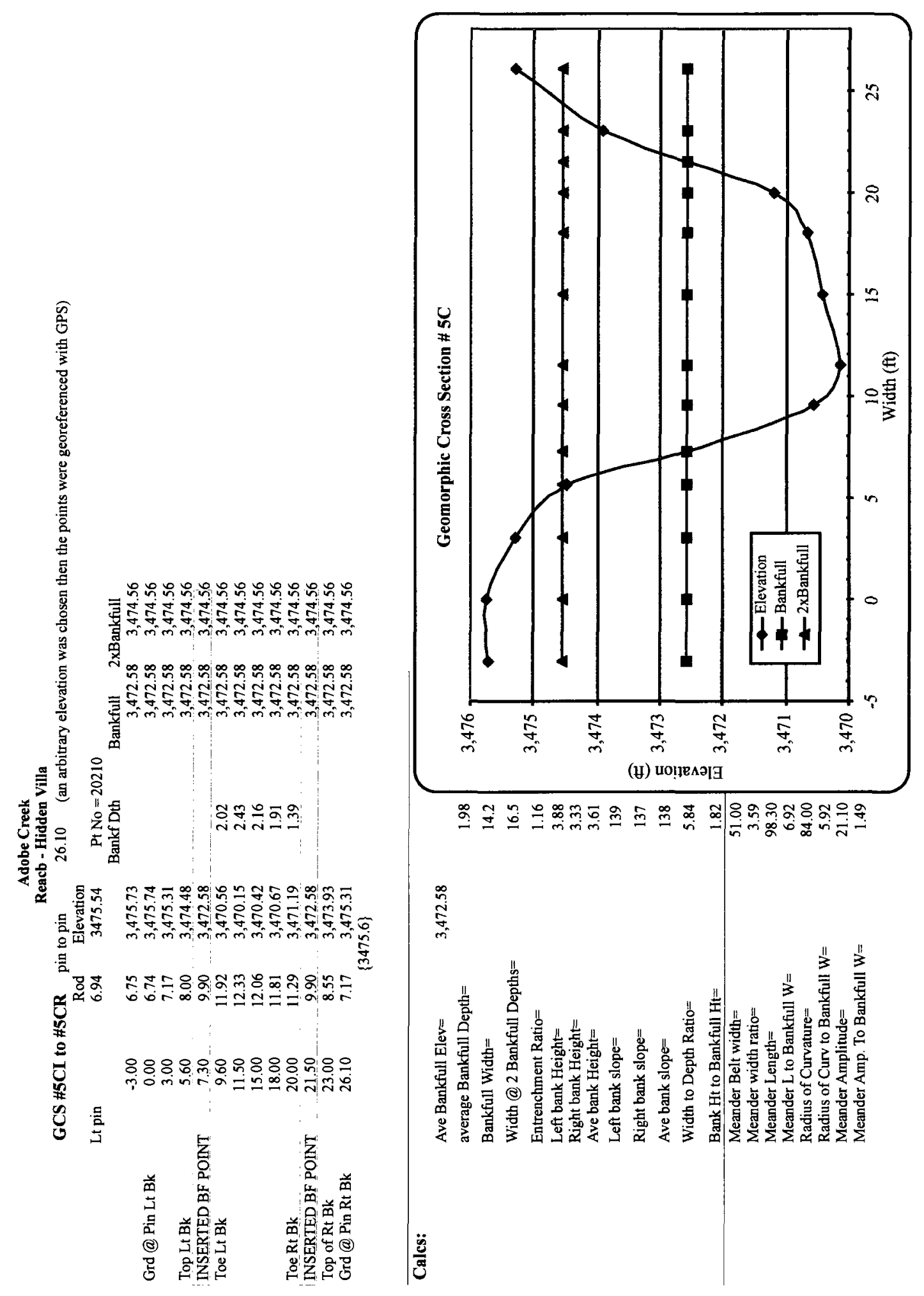



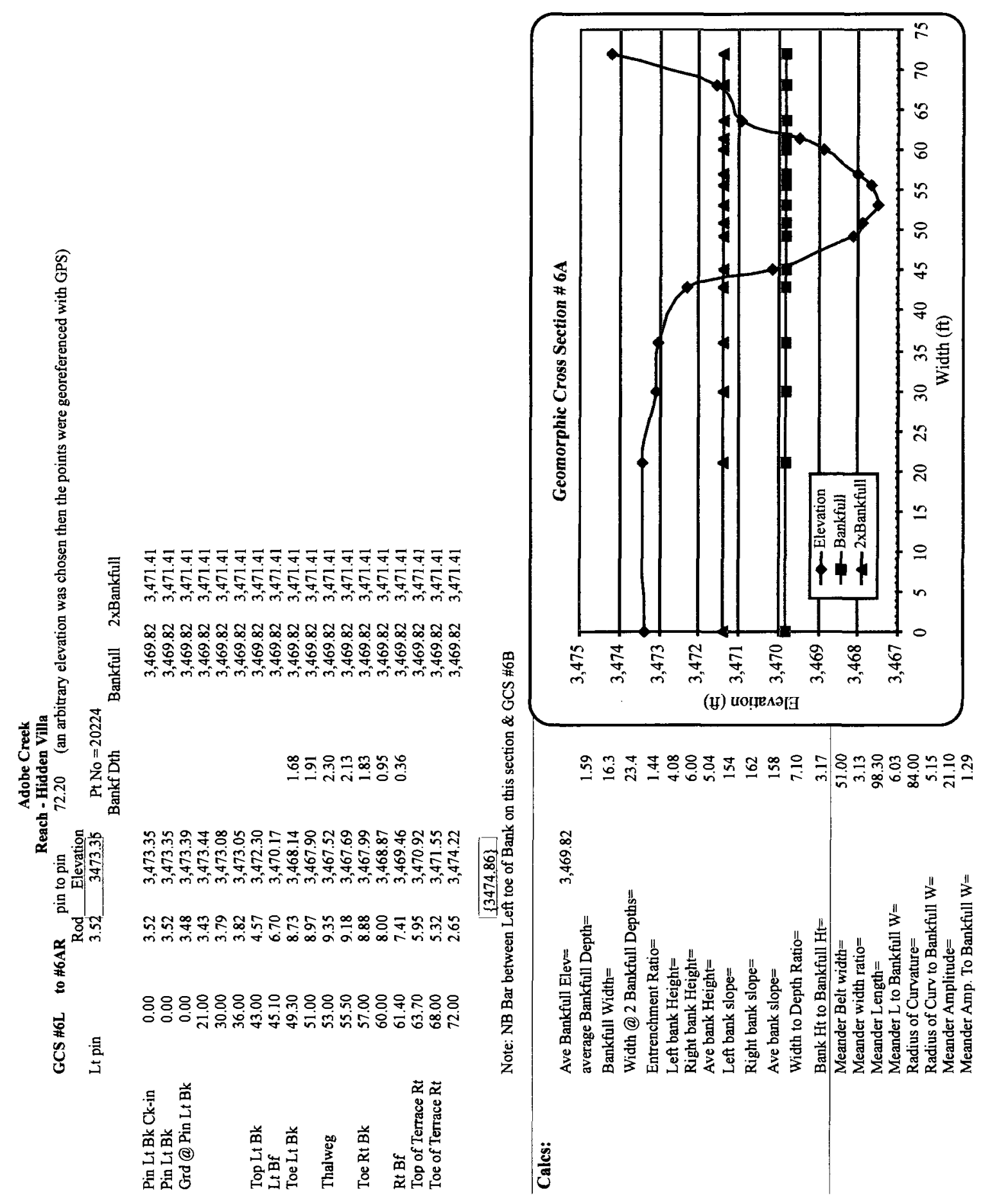


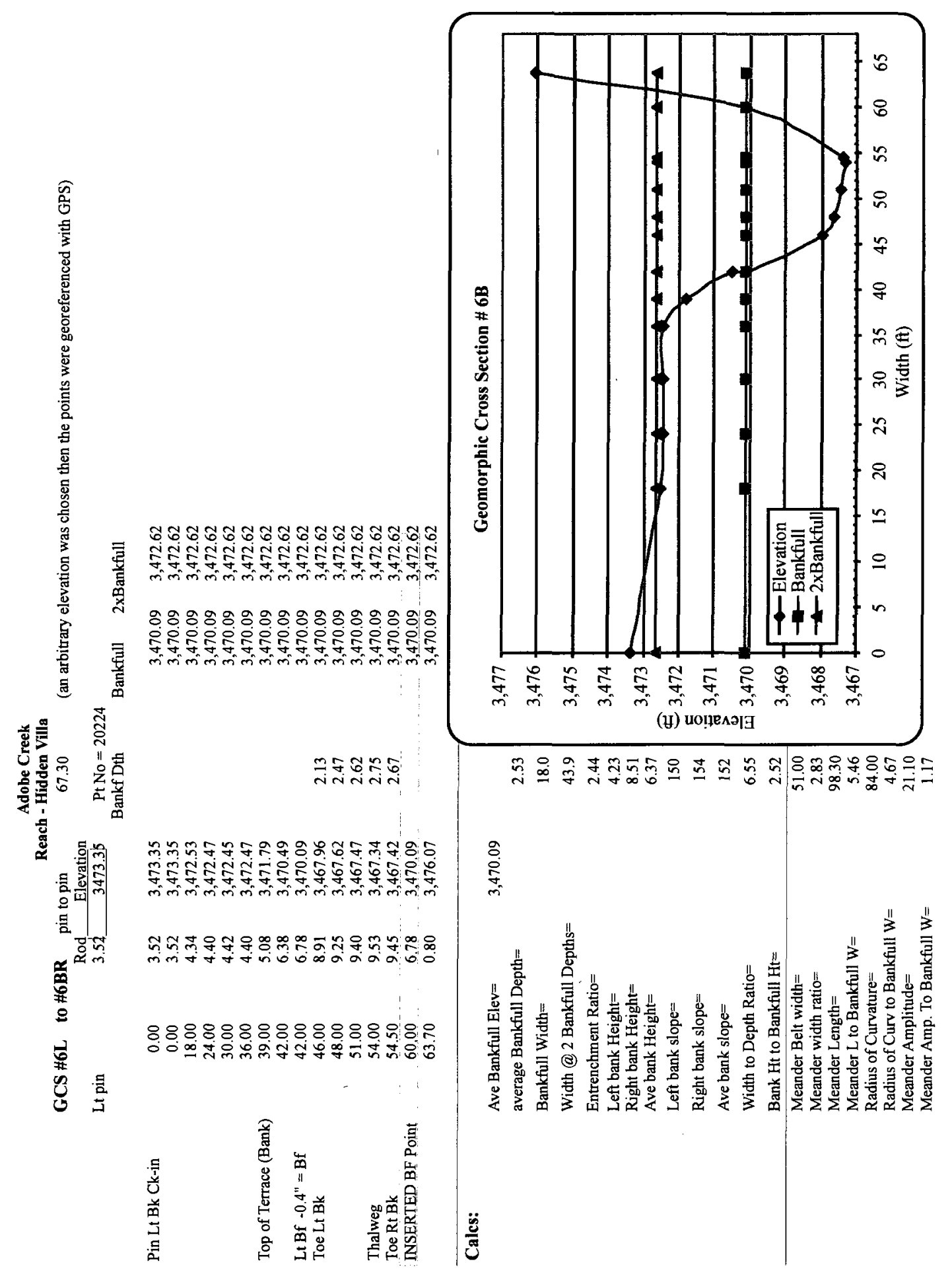




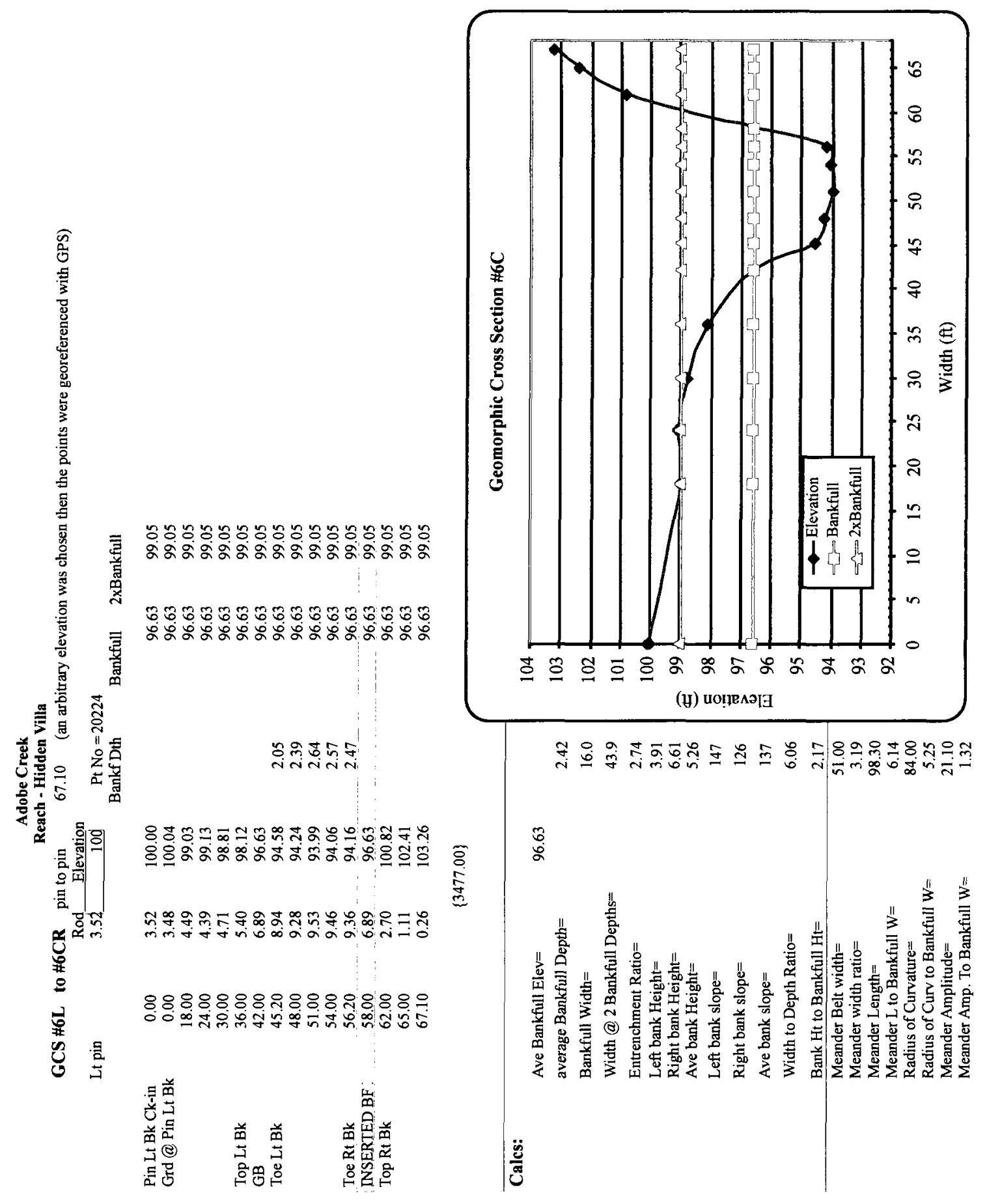




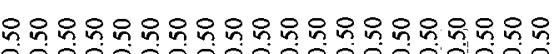

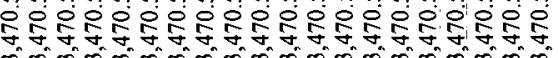

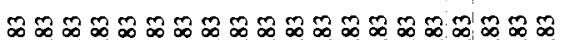

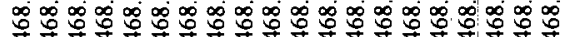

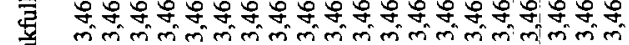
m

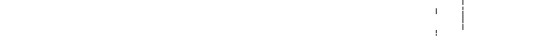

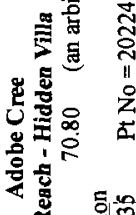

ㄱ.

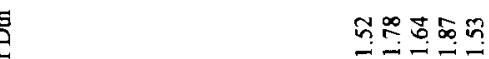

空

mై

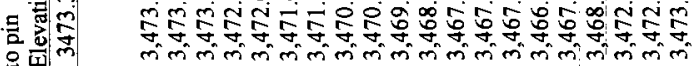

言

总莜

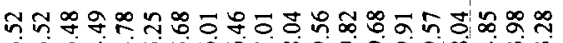

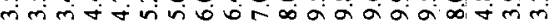

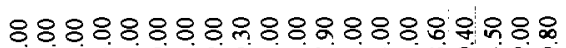

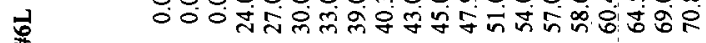

设 豆

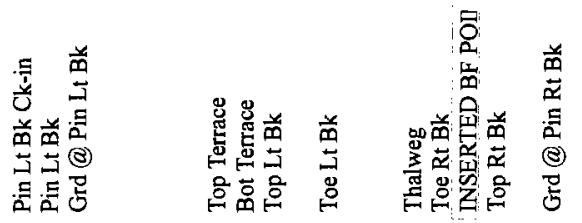

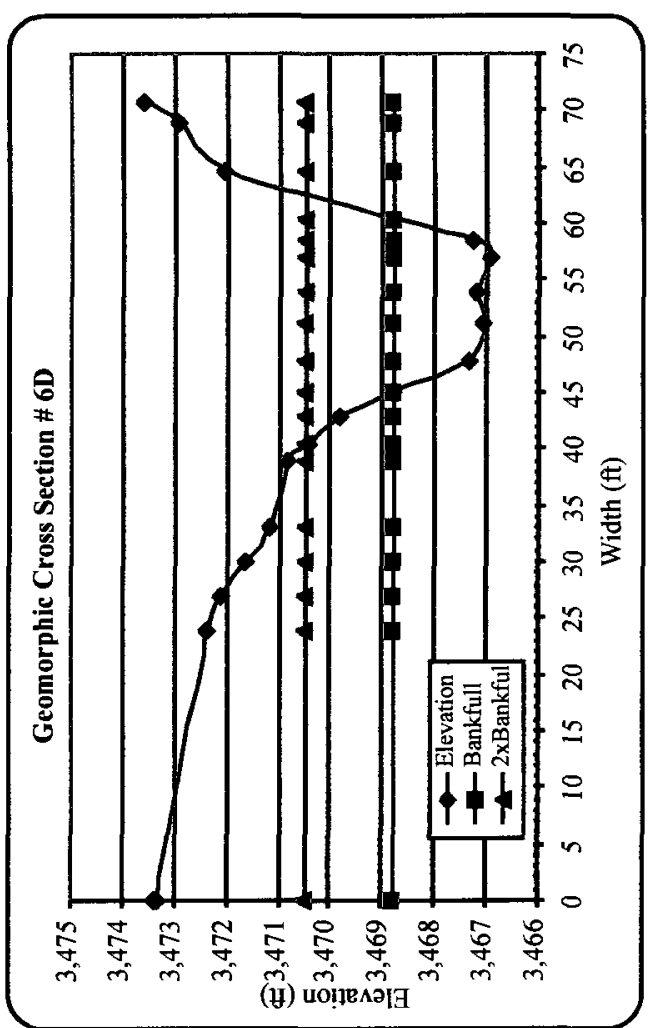

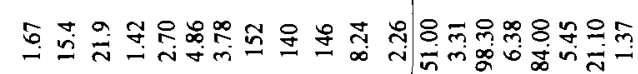

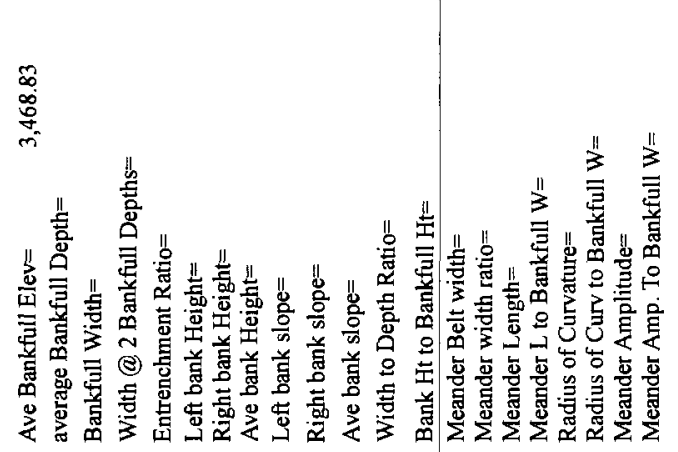




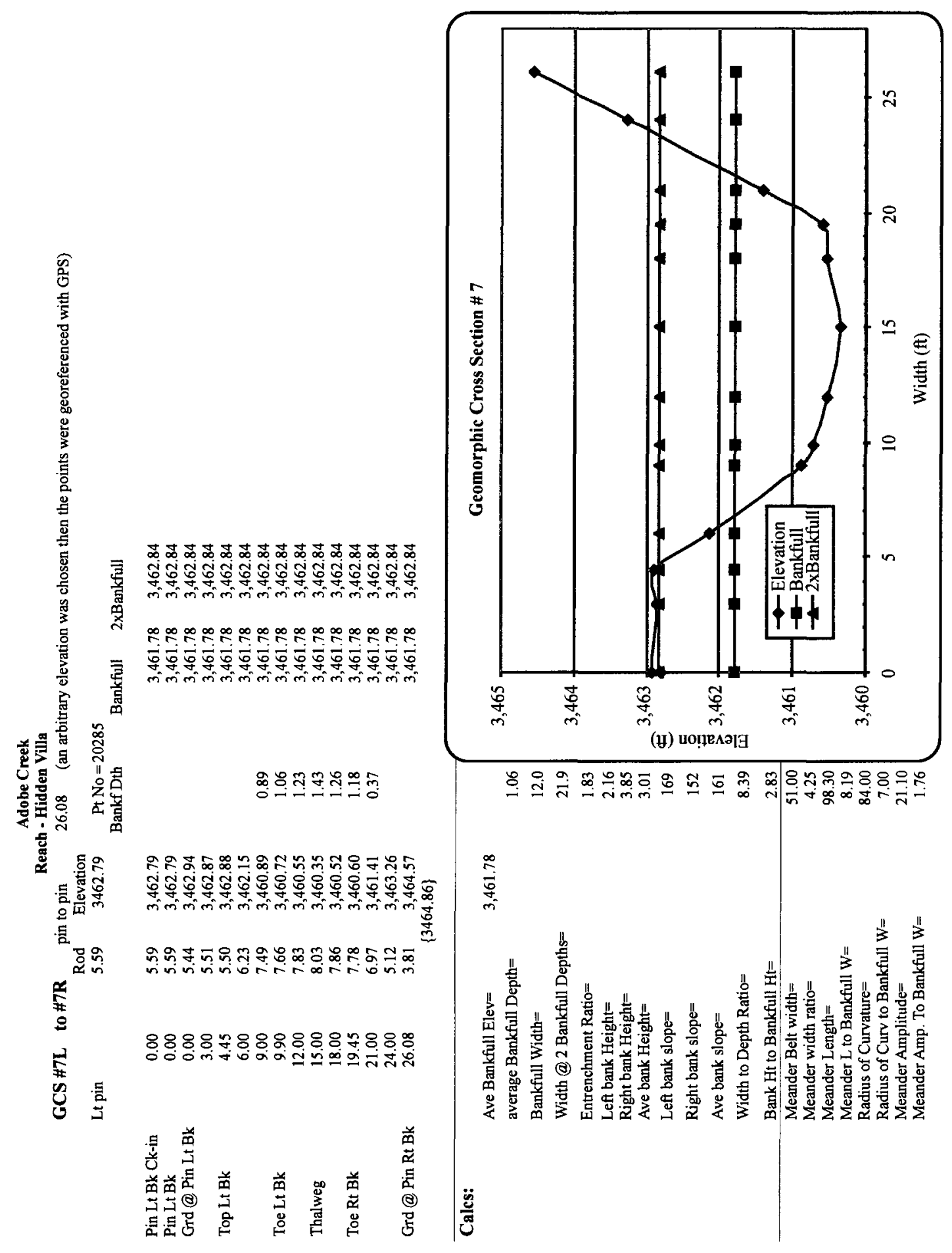




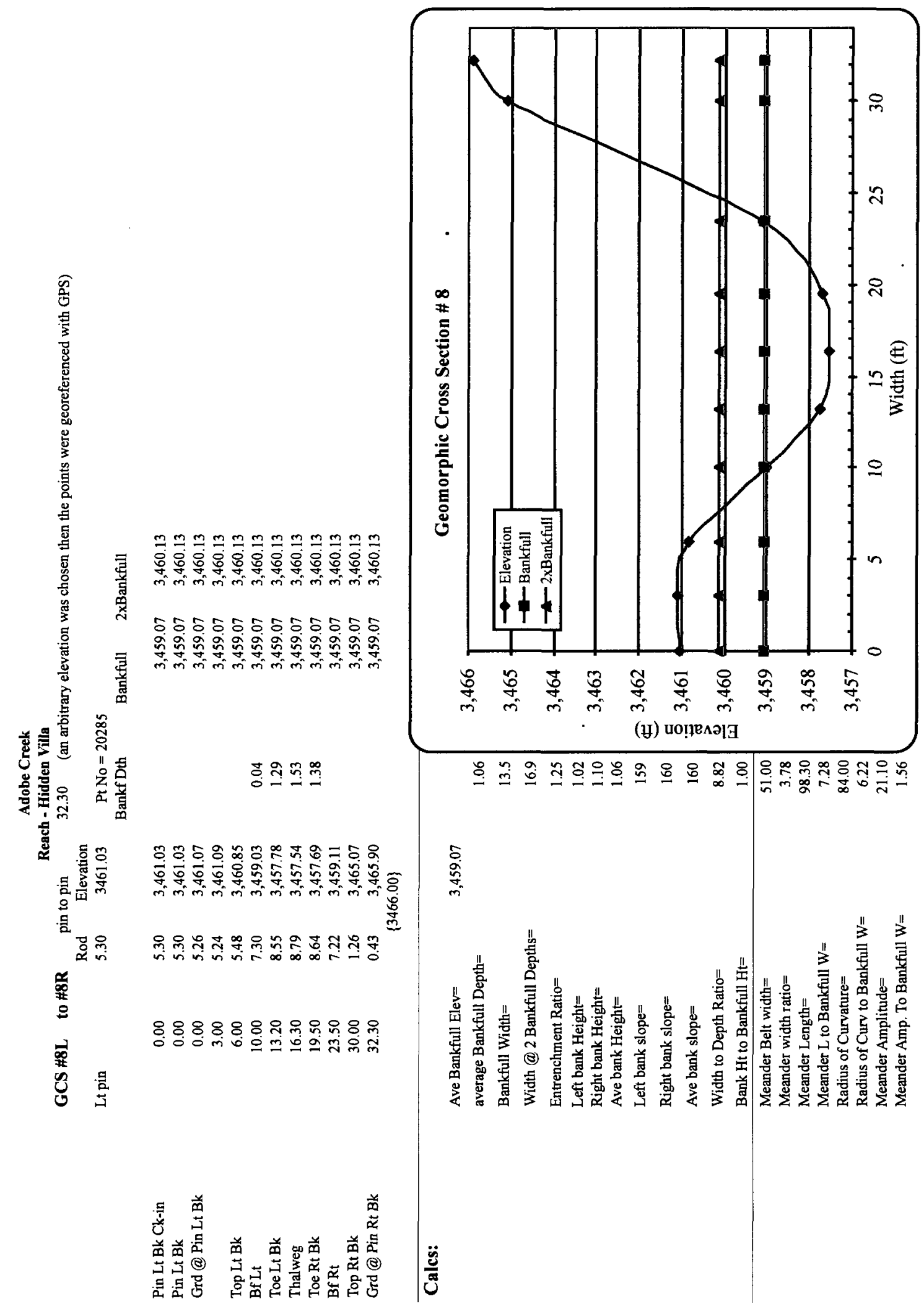




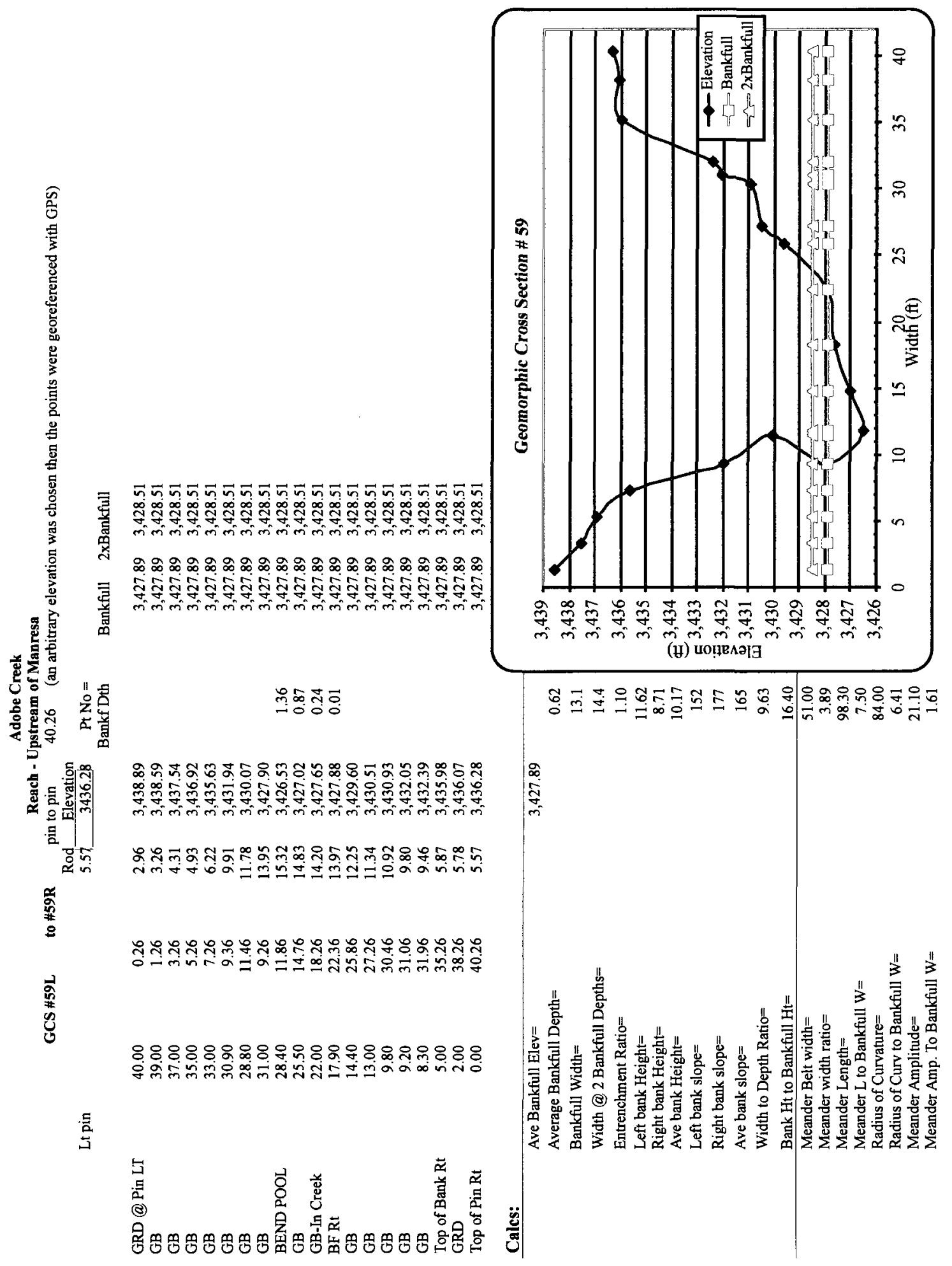




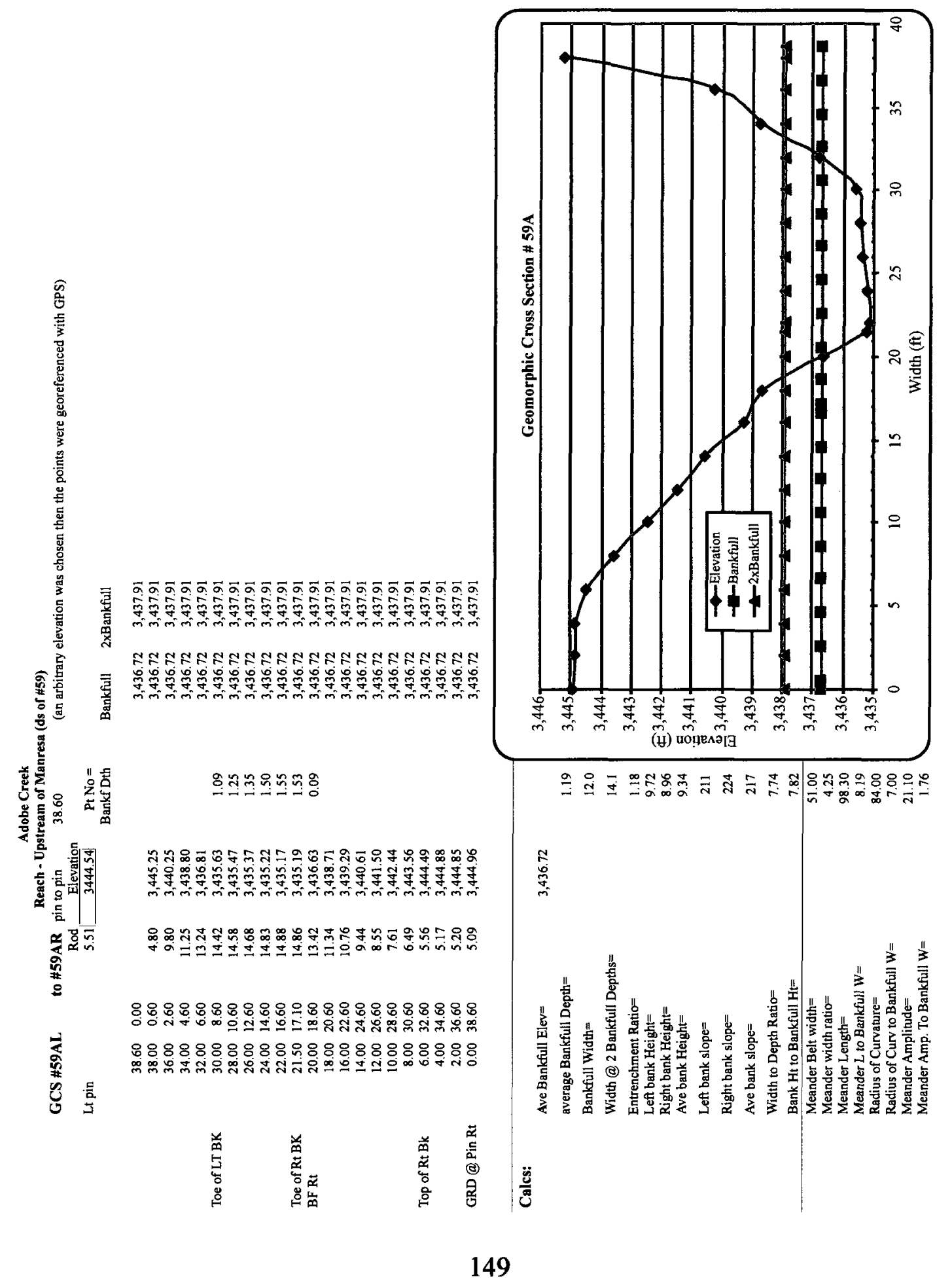




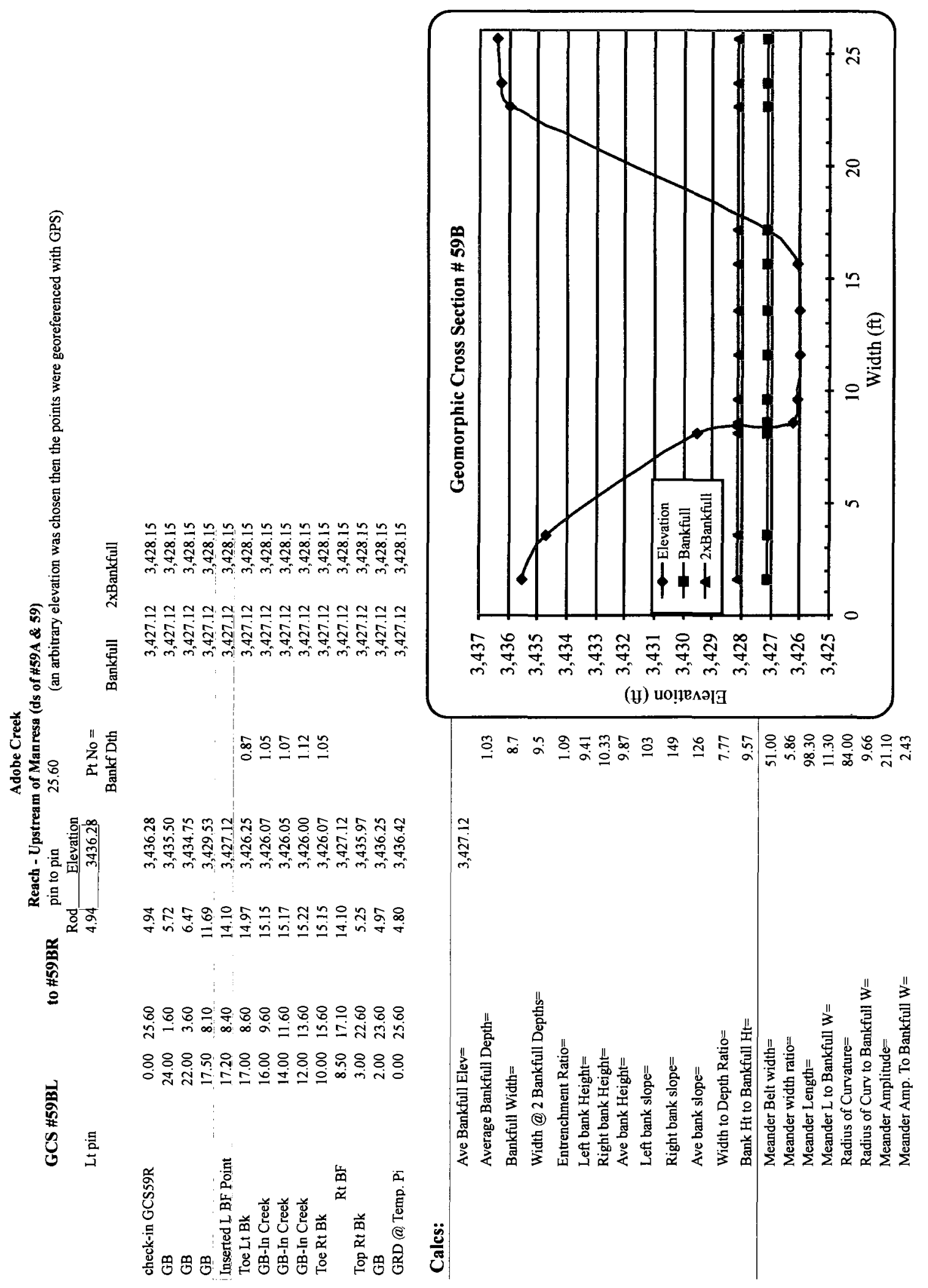




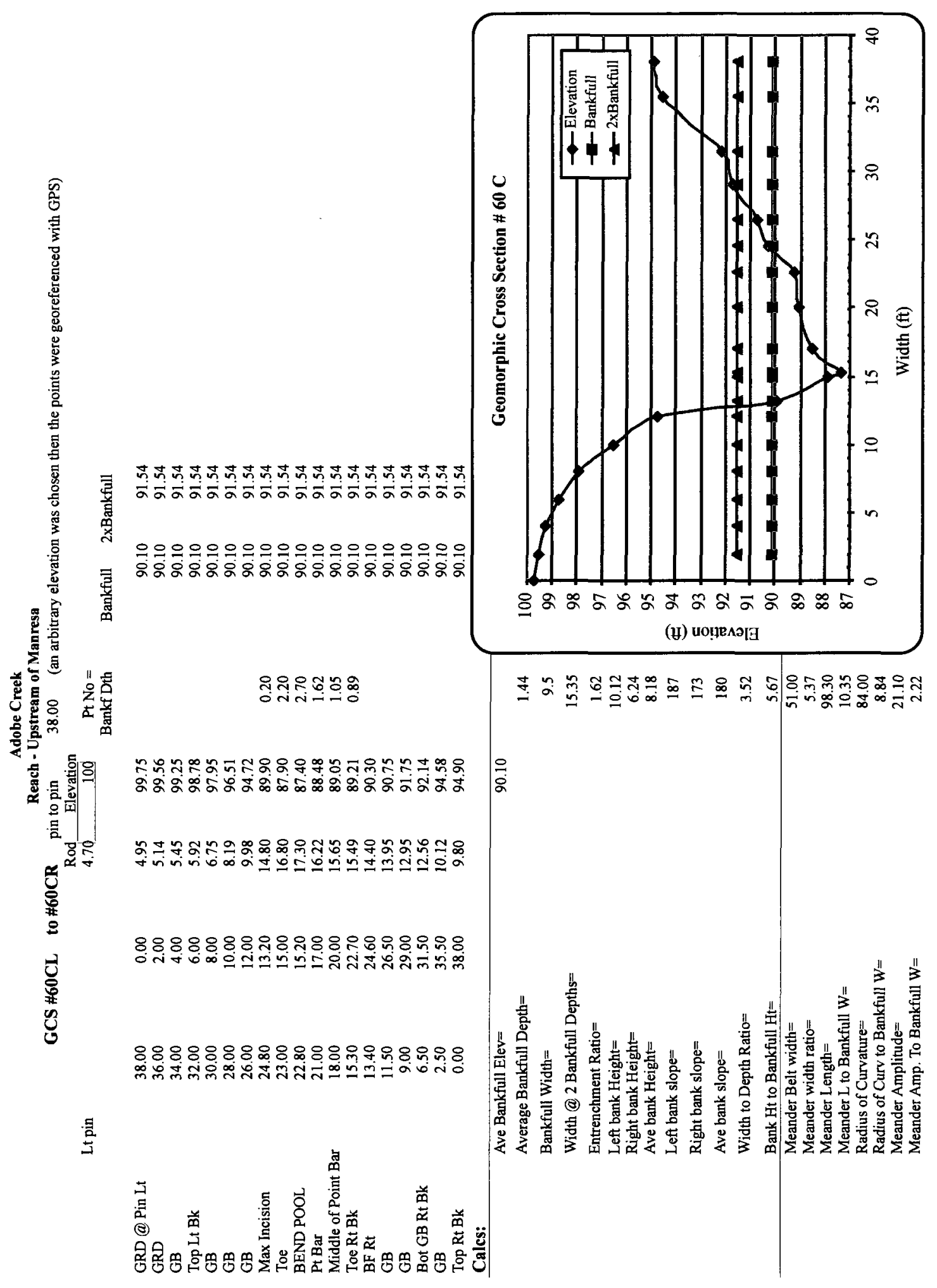




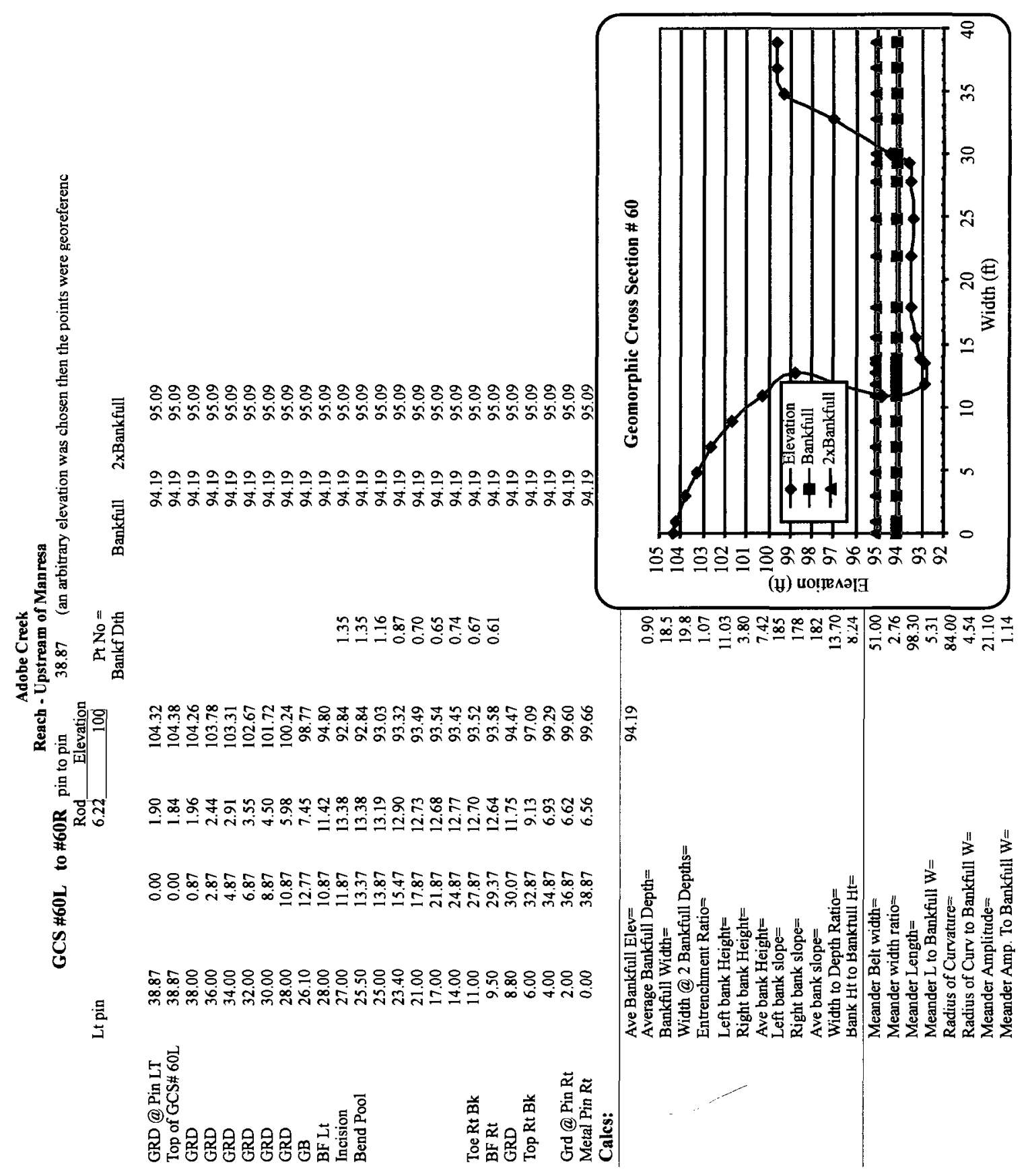




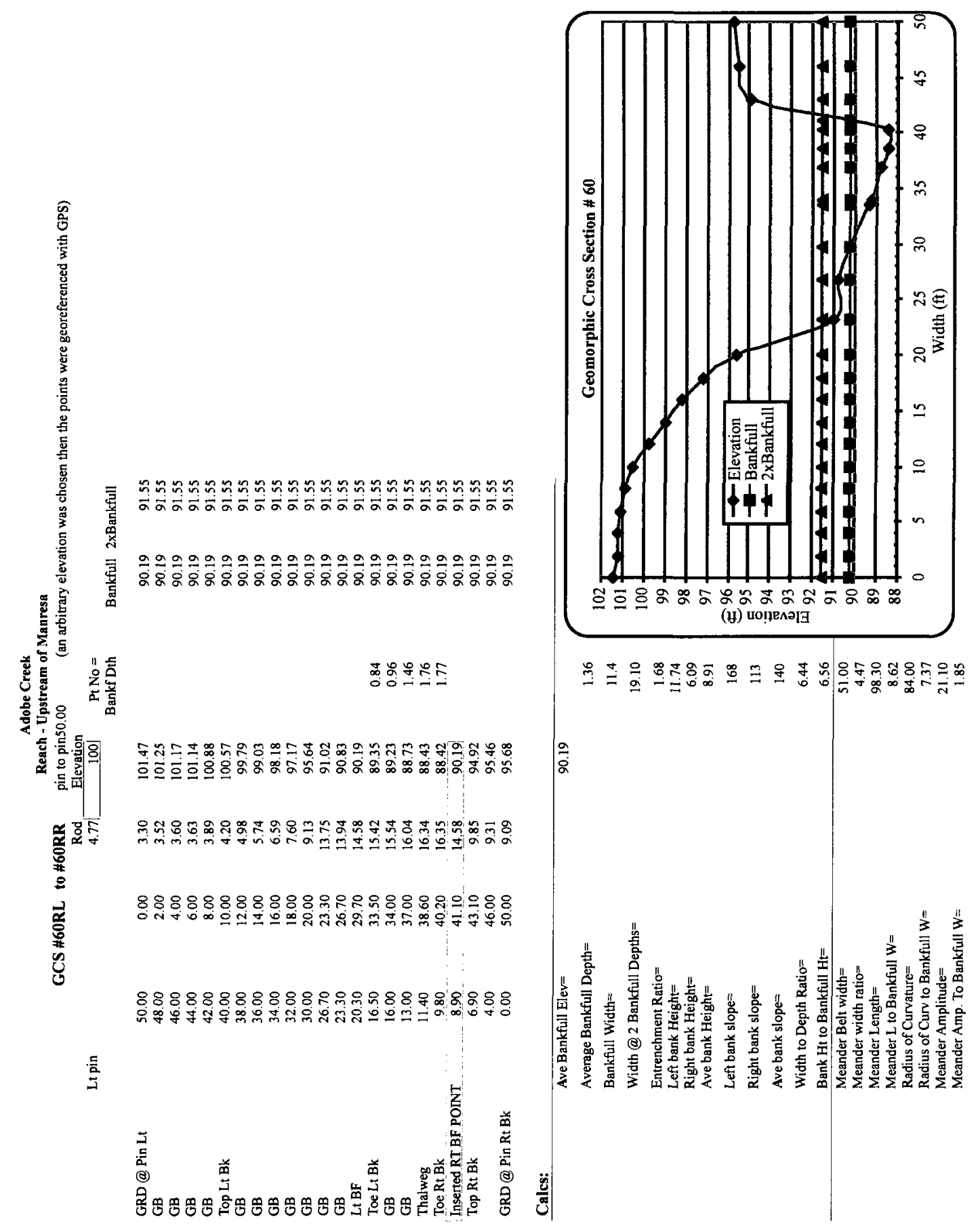




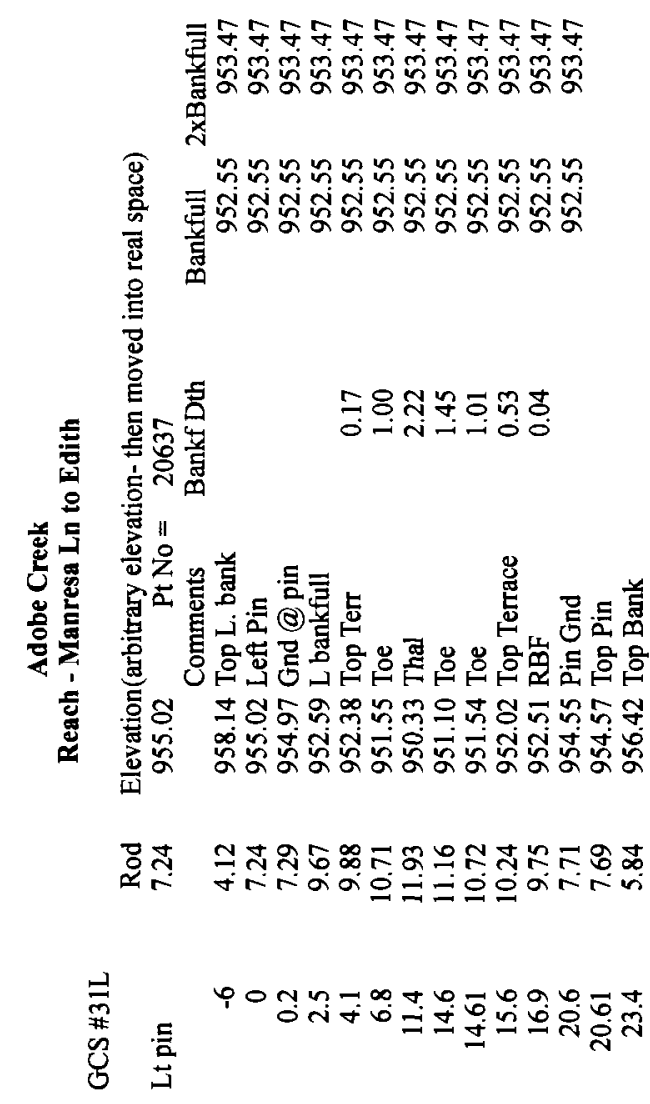

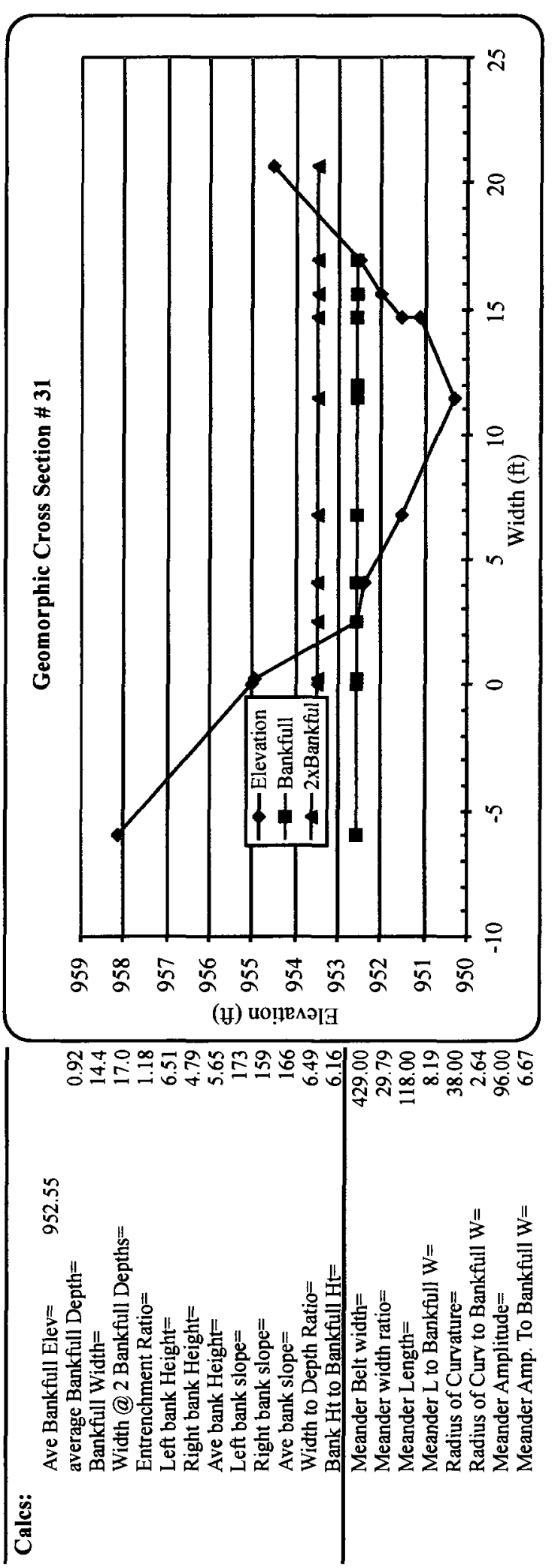



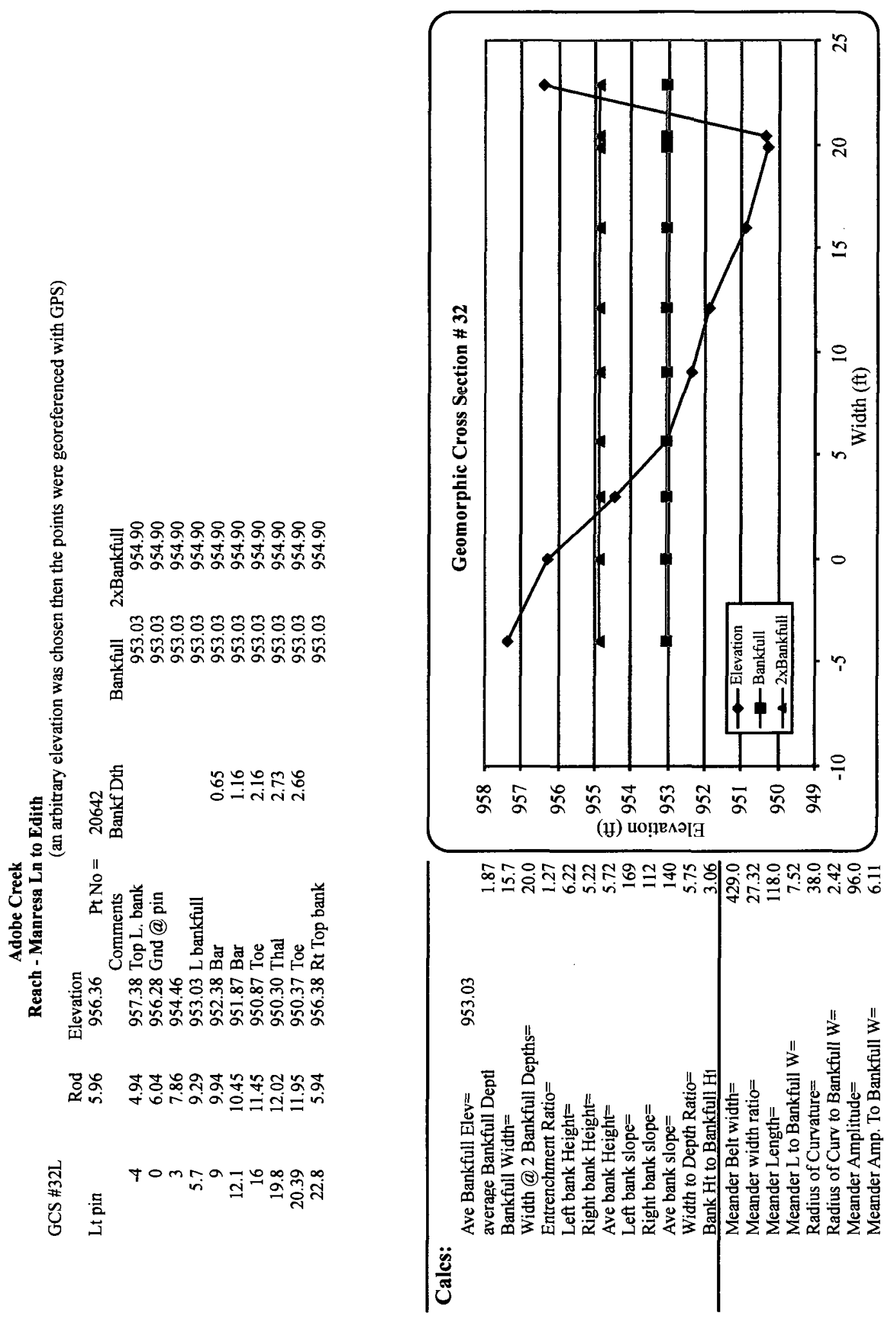


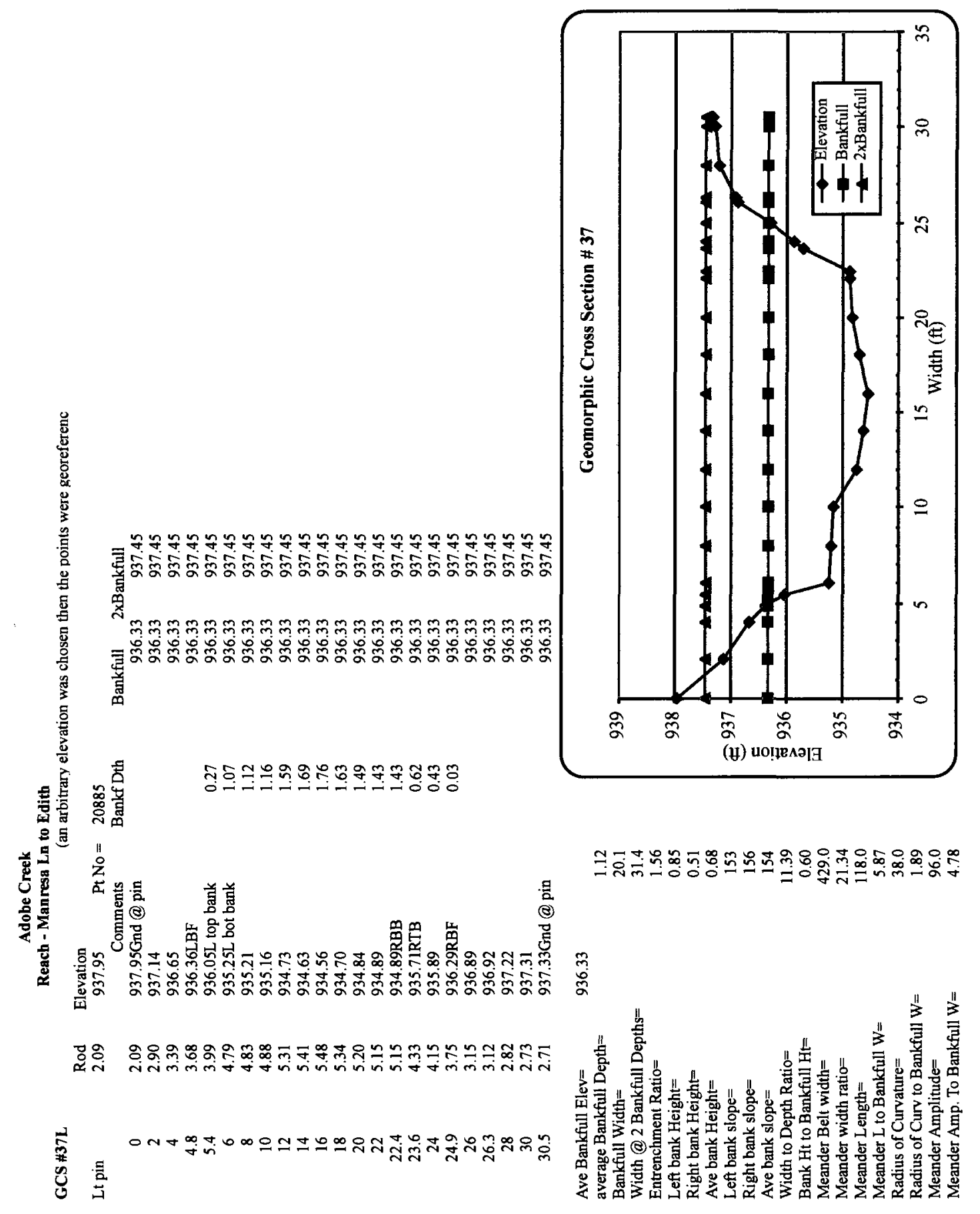




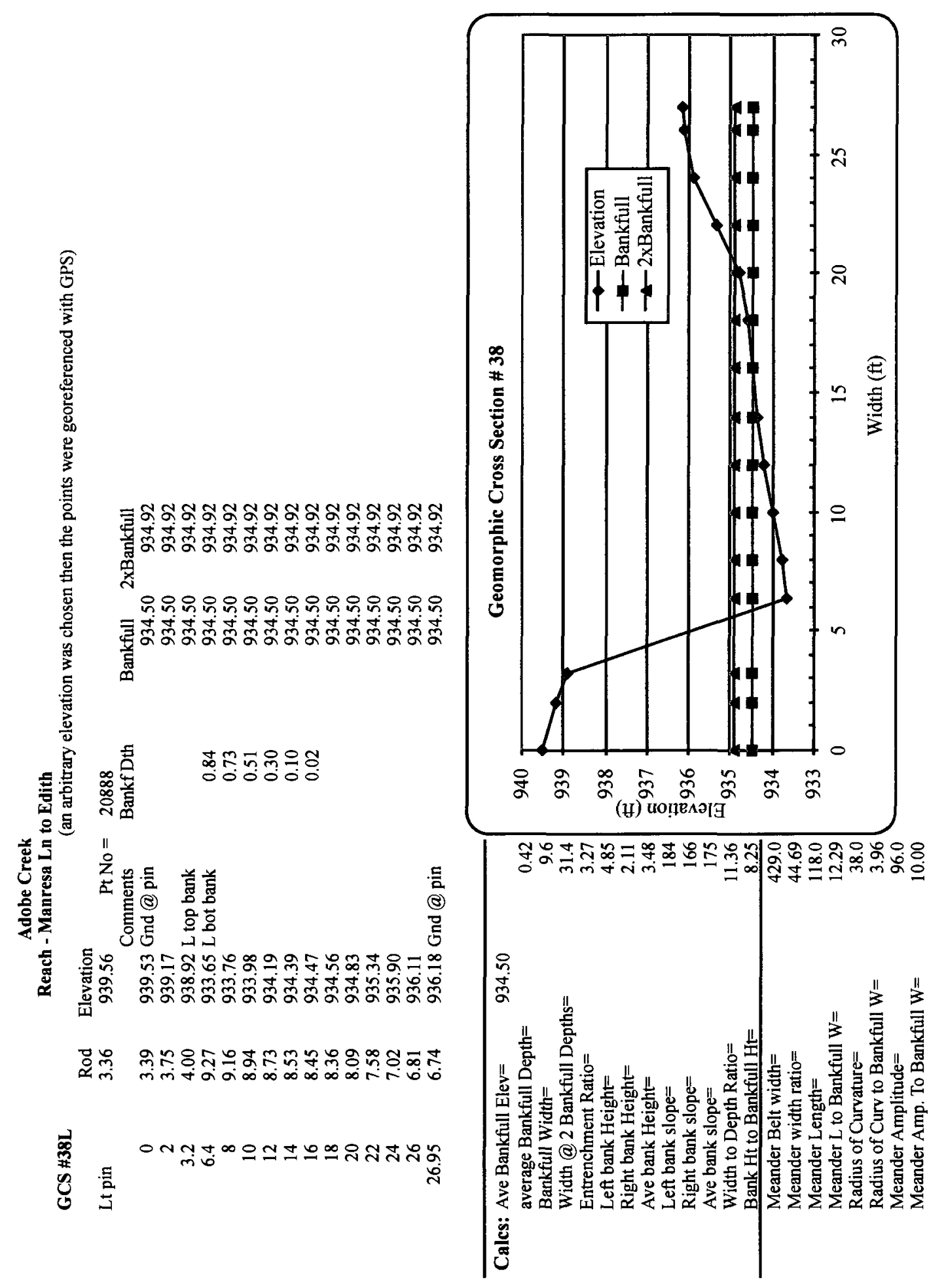




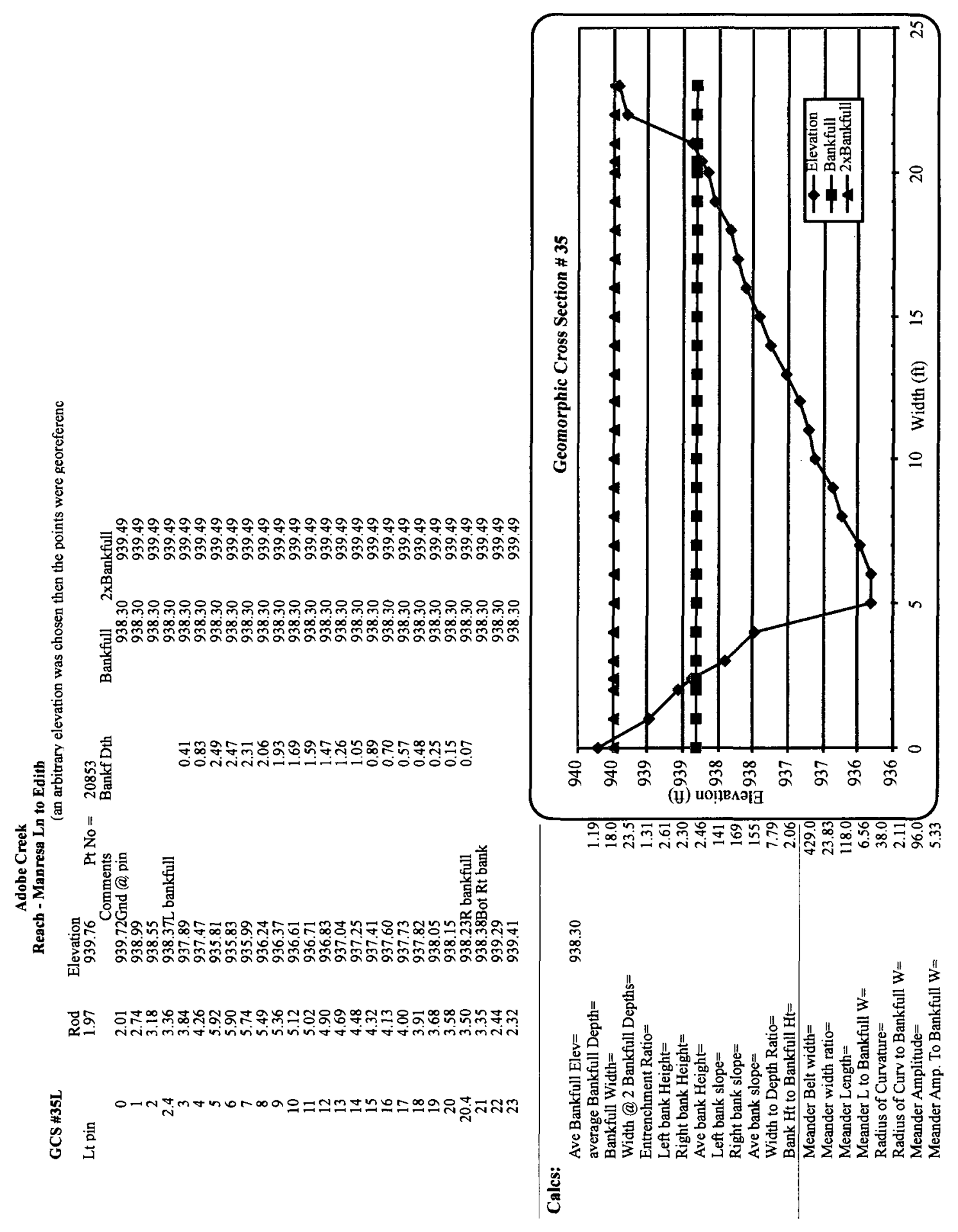




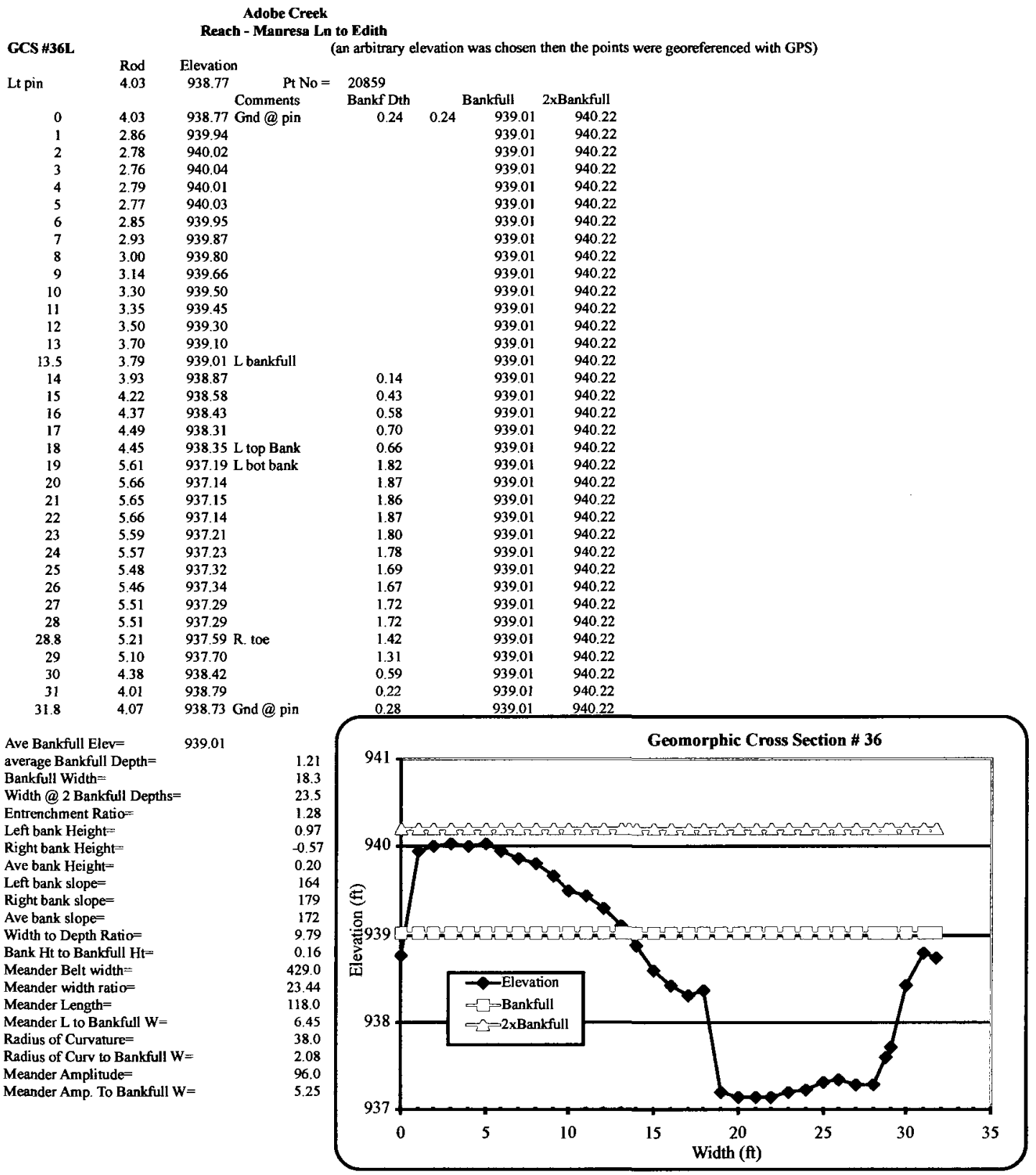




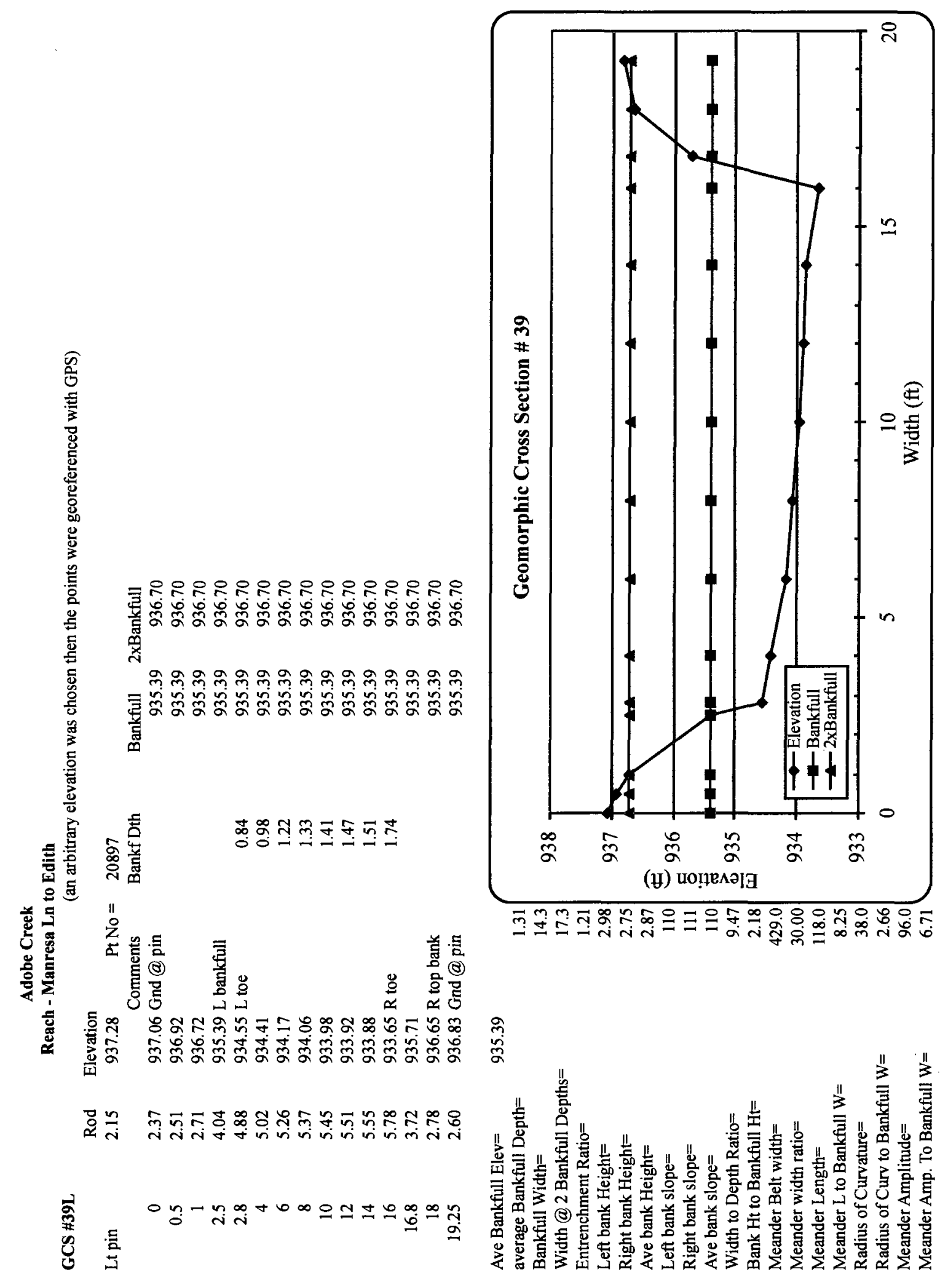




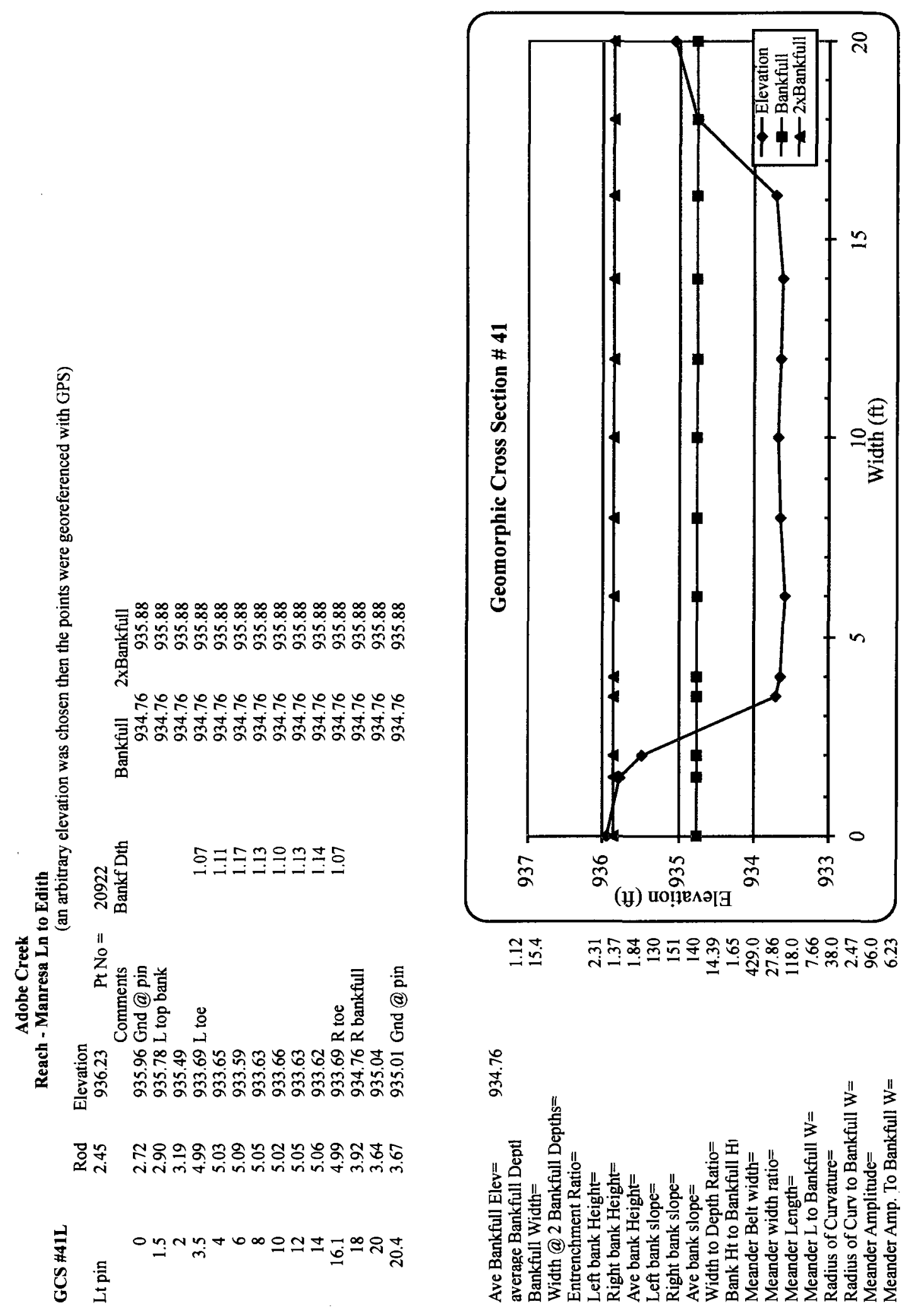




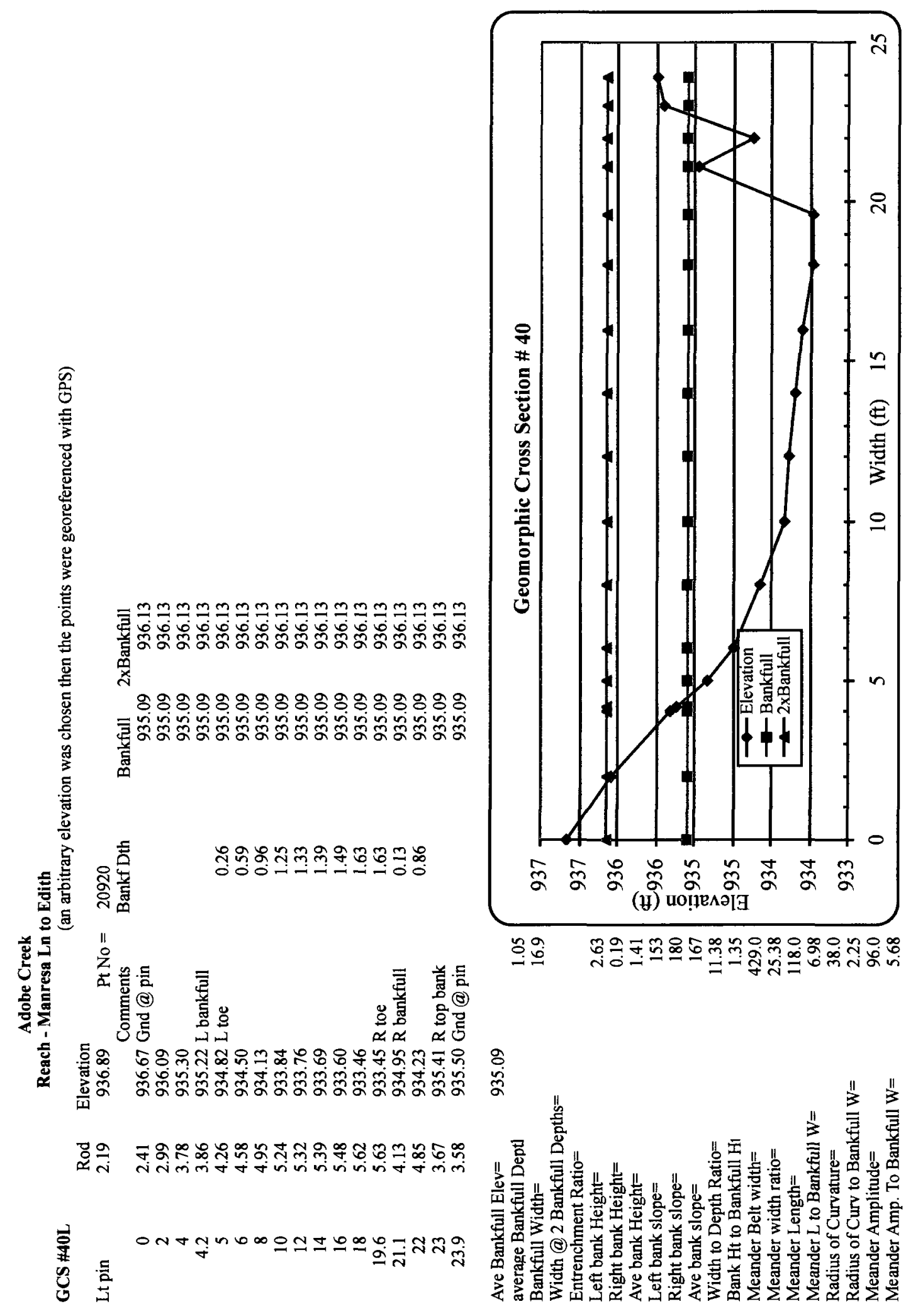




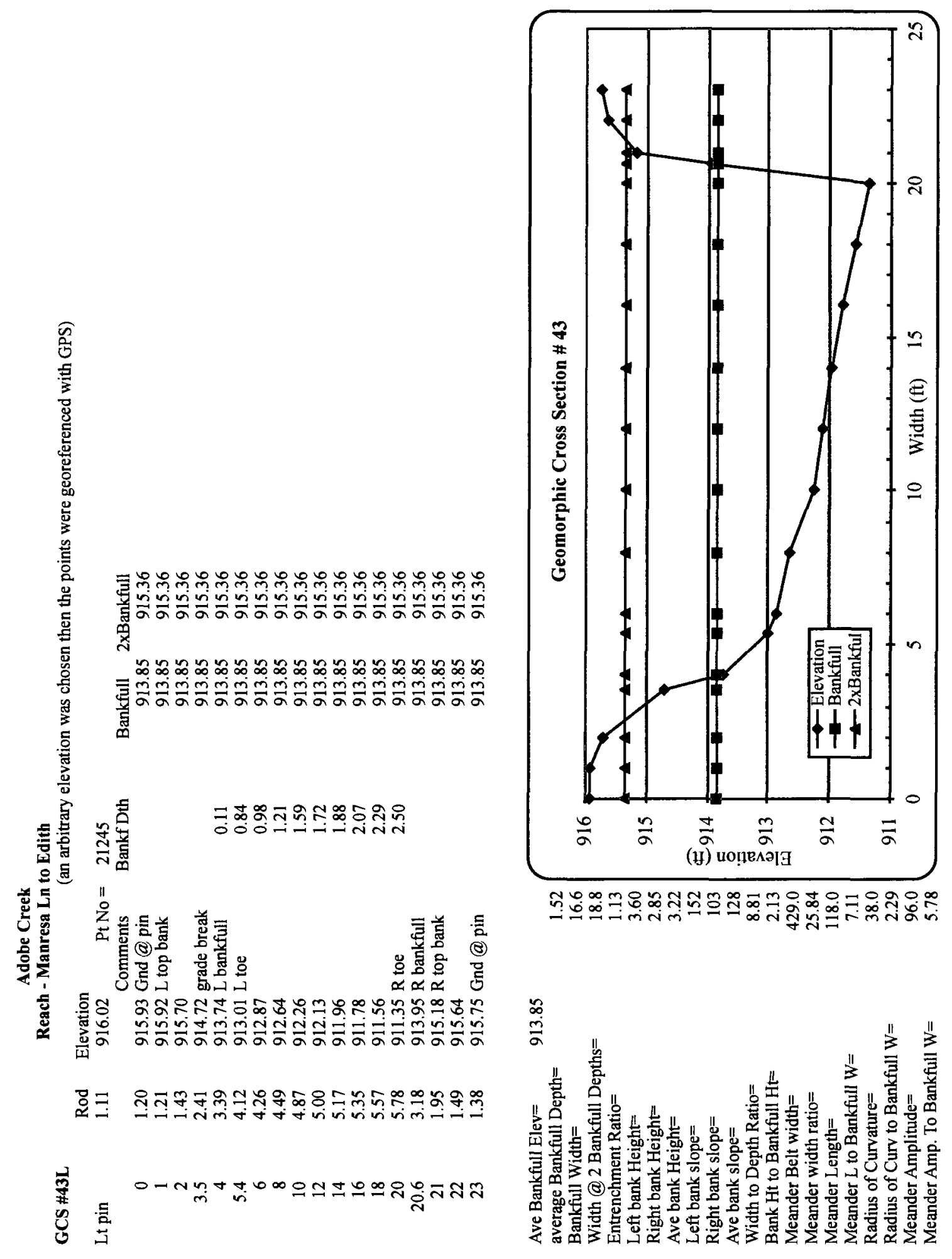




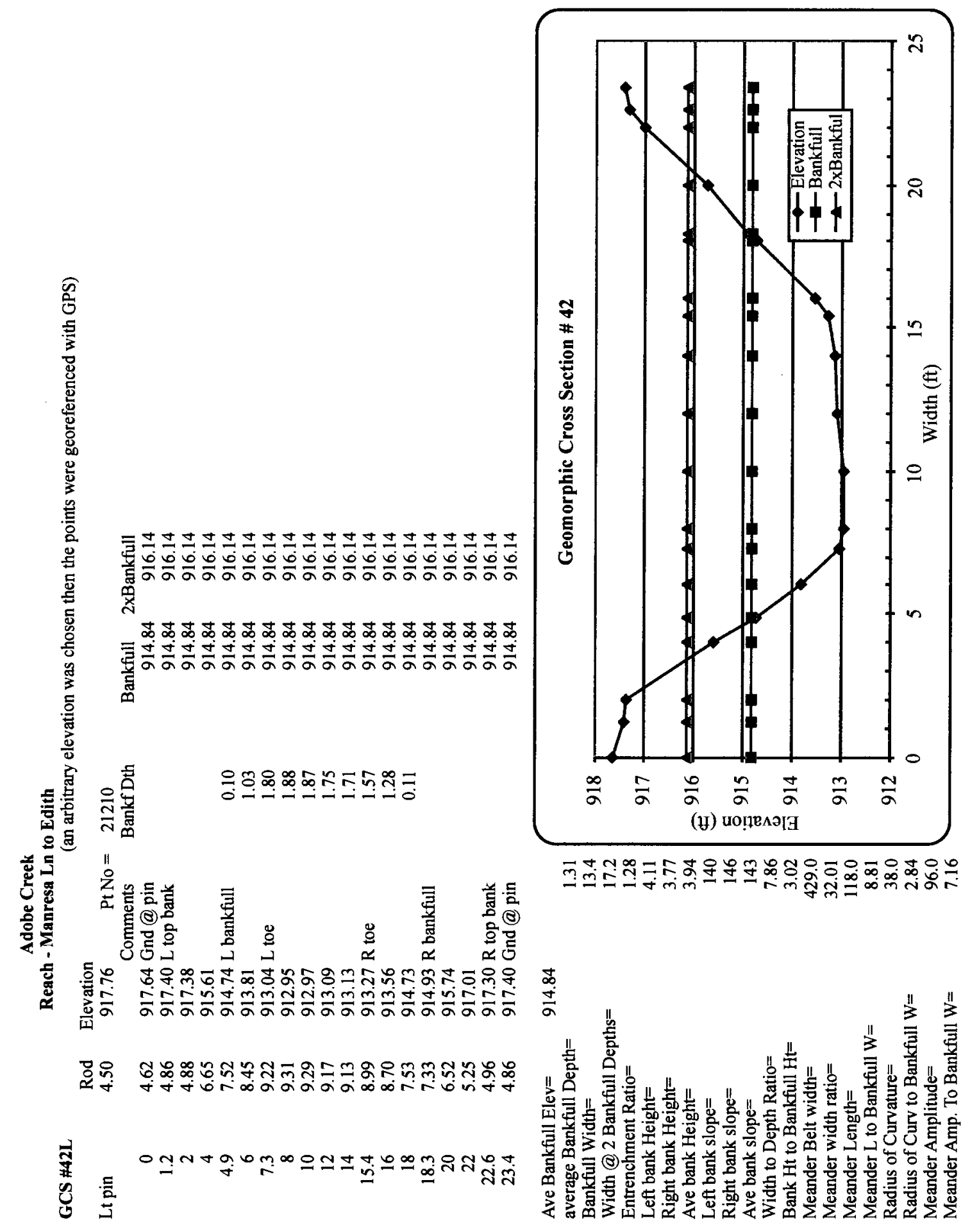




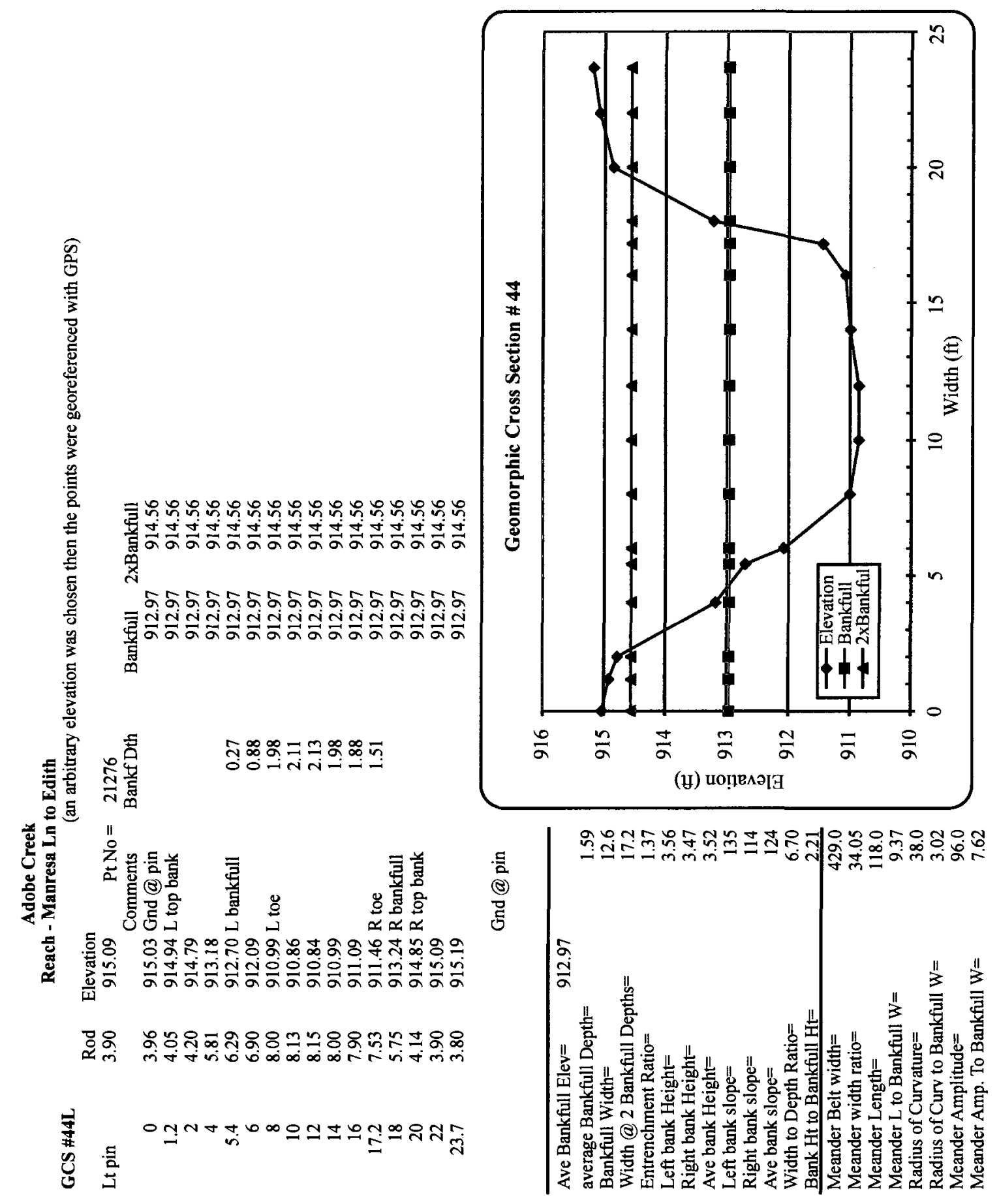




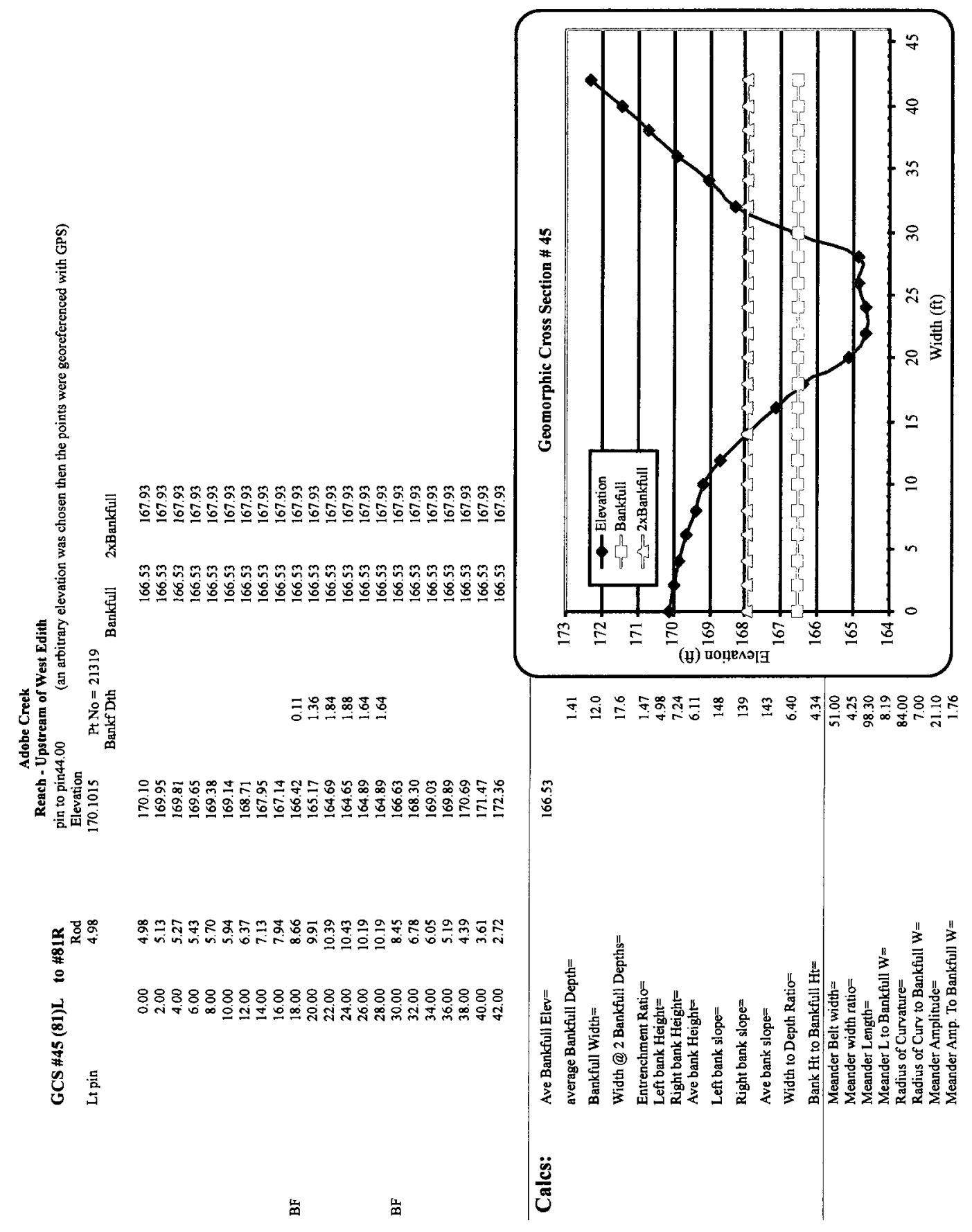




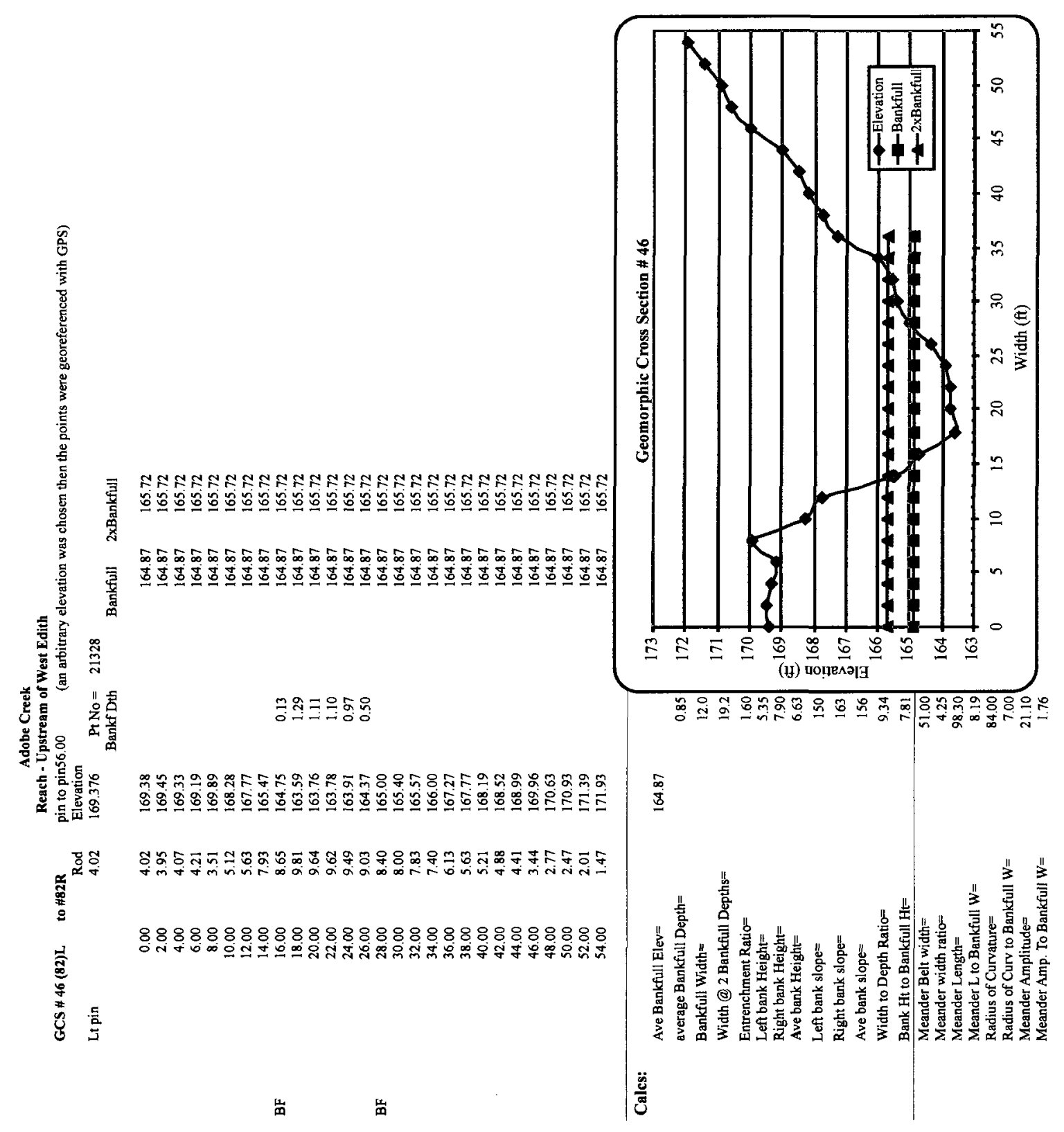




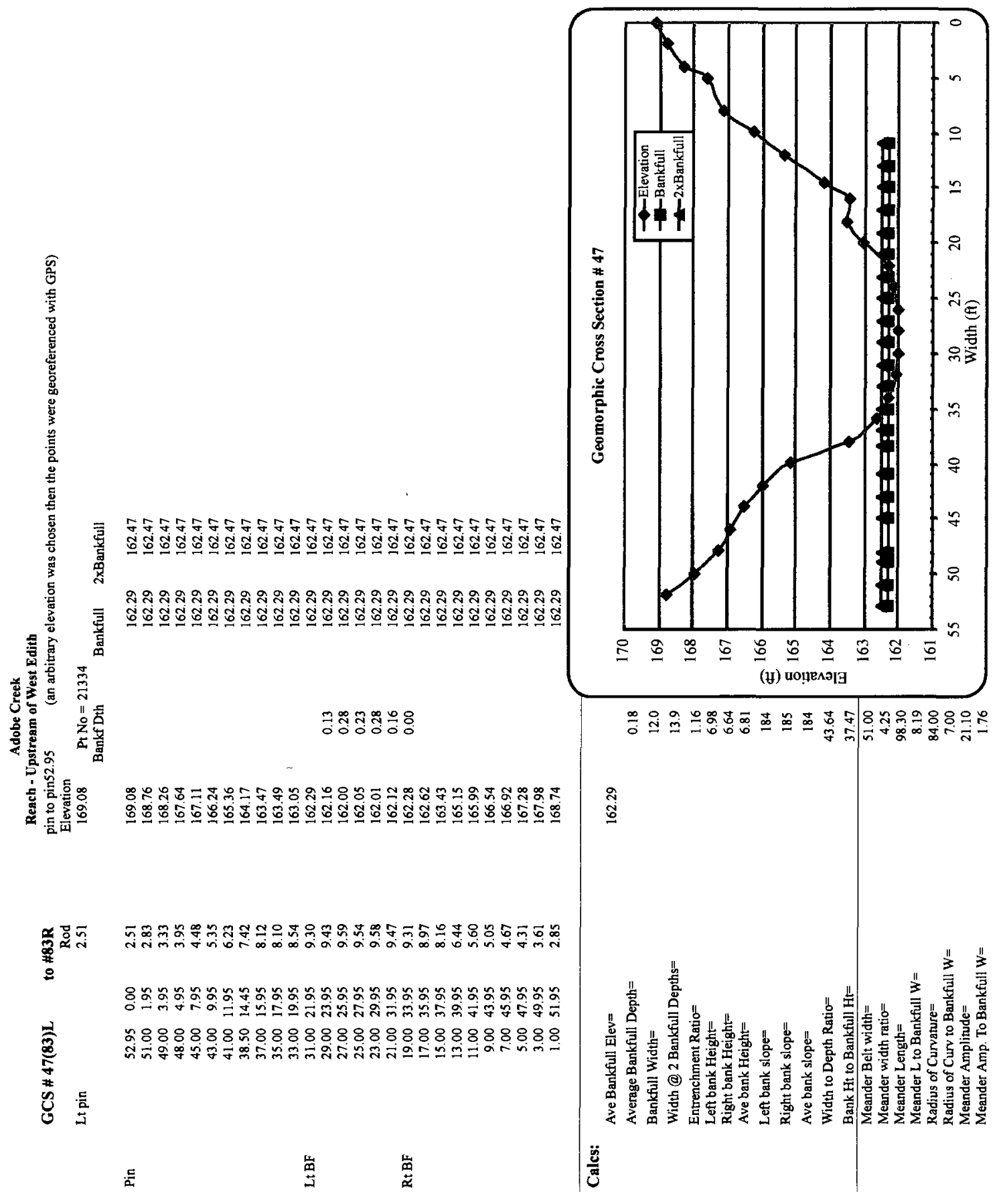




\section{APPENDIX C}

\section{Pebble Counts}




\begin{tabular}{|c|c|c|c|c|}
\hline \multicolumn{2}{|c|}{ Adobe Creek } & $\# 1$ & & \multirow[b]{2}{*}{ Cum $\%$} \\
\hline & $\begin{array}{l}\text { Size } \\
\mathrm{mm}\end{array}$ & Count & $\%$ & \\
\hline \multirow[t]{52}{*}{ Silt } & 0.063 & 6 & $6.7 \%$ & $6.7 \%$ \\
\hline & 2 & 3 & $3.3 \%$ & $10.0 \%$ \\
\hline & 3 & 1 & $1.1 \%$ & $11.1 \%$ \\
\hline & 5 & 1 & $1.1 \%$ & $12.2 \%$ \\
\hline & 10 & 1 & $1.1 \%$ & $13.3 \%$ \\
\hline & 12 & 1 & $1.1 \%$ & $14.4 \%$ \\
\hline & 15 & 2 & $2.2 \%$ & $16.7 \%$ \\
\hline & 18 & 1 & $1.1 \%$ & $17.8 \%$ \\
\hline & 19 & 2 & $2.2 \%$ & $20.0 \%$ \\
\hline & 20 & 2 & $2.2 \%$ & $22.2 \%$ \\
\hline & 21 & 1 & $1.1 \%$ & $23.3 \%$ \\
\hline & 24 & 1 & $1.1 \%$ & $24.4 \%$ \\
\hline & 25 & 2 & $2.2 \%$ & $26.7 \%$ \\
\hline & 26 & 1 & $1.1 \%$ & $27.8 \%$ \\
\hline & 28 & 1 & $1.1 \%$ & $28.9 \%$ \\
\hline & 30 & 3 & $3.3 \%$ & $32.2 \%$ \\
\hline & 31 & 1 & $1.1 \%$ & $33.3 \%$ \\
\hline & 32 & 3 & $3.3 \%$ & $36.7 \%$ \\
\hline & 35 & 1 & $1.1 \%$ & $37.8 \%$ \\
\hline & 36 & 1 & $1.1 \%$ & $38.9 \%$ \\
\hline & 37 & 2 & $2.2 \%$ & $41.1 \%$ \\
\hline & 44 & 1 & $1.1 \%$ & $42.2 \%$ \\
\hline & 45 & 1 & $1.1 \%$ & $43.3 \%$ \\
\hline & 50 & 3 & $3.3 \%$ & $46.7 \%$ \\
\hline & 52 & 2 & $2.2 \%$ & $48.9 \%$ \\
\hline & 55 & 2 & $2.2 \%$ & $51.1 \%$ \\
\hline & 60 & 2 & $2.2 \%$ & $53.3 \%$ \\
\hline & 62 & 1 & $1.1 \%$ & $54.4 \%$ \\
\hline & 65 & 1 & $1.1 \%$ & $55.6 \%$ \\
\hline & 70 & 3 & $3.3 \%$ & $58.9 \%$ \\
\hline & 75 & 1 & $1.1 \%$ & $60.0 \%$ \\
\hline & 80 & 3 & $3.3 \%$ & $63.3 \%$ \\
\hline & 90 & 1 & $1.1 \%$ & $64.4 \%$ \\
\hline & 95 & 1 & $1.1 \%$ & $65.6 \%$ \\
\hline & 100 & 1 & $1.1 \%$ & $66.7 \%$ \\
\hline & 105 & 1 & $1.1 \%$ & $67.8 \%$ \\
\hline & 110 & 1 & $1.1 \%$ & $68.9 \%$ \\
\hline & 120 & 4 & $4.4 \%$ & $73.3 \%$ \\
\hline & 130 & 2 & $2.2 \%$ & $75.6 \%$ \\
\hline & 135 & 1 & $1.1 \%$ & $76.7 \%$ \\
\hline & 140 & 2 & $2.2 \%$ & $78.9 \%$ \\
\hline & 150 & 2 & $2.2 \%$ & $81.1 \%$ \\
\hline & 170 & 1 & $1.1 \%$ & $82.2 \%$ \\
\hline & 190 & 1 & $1.1 \%$ & $83.3 \%$ \\
\hline & 200 & 1 & $1.1 \%$ & $84.4 \%$ \\
\hline & 210 & 4 & $4.4 \%$ & $88.9 \%$ \\
\hline & 220 & 1 & $1.1 \%$ & $90.0 \%$ \\
\hline & 240 & 1 & $1.1 \%$ & $91.1 \%$ \\
\hline & 300 & 3 & $3.3 \%$ & $94.4 \%$ \\
\hline & 320 & 1 & $1.1 \%$ & $95.6 \%$ \\
\hline & 390 & 1 & $1.1 \%$ & $96.7 \%$ \\
\hline & 450 & 3 & $3.3 \%$ & $100.0 \%$ \\
\hline
\end{tabular}

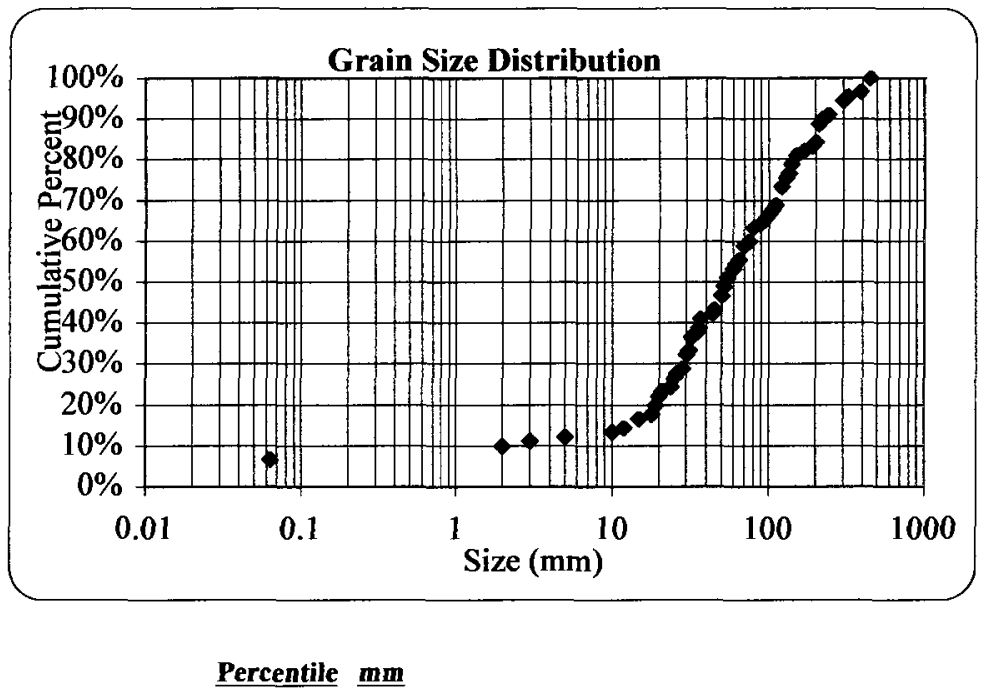

$\begin{array}{lr}\text { d84 } & 196 \\ \text { d50 } & 54 \\ \text { d16 } & 14\end{array}$




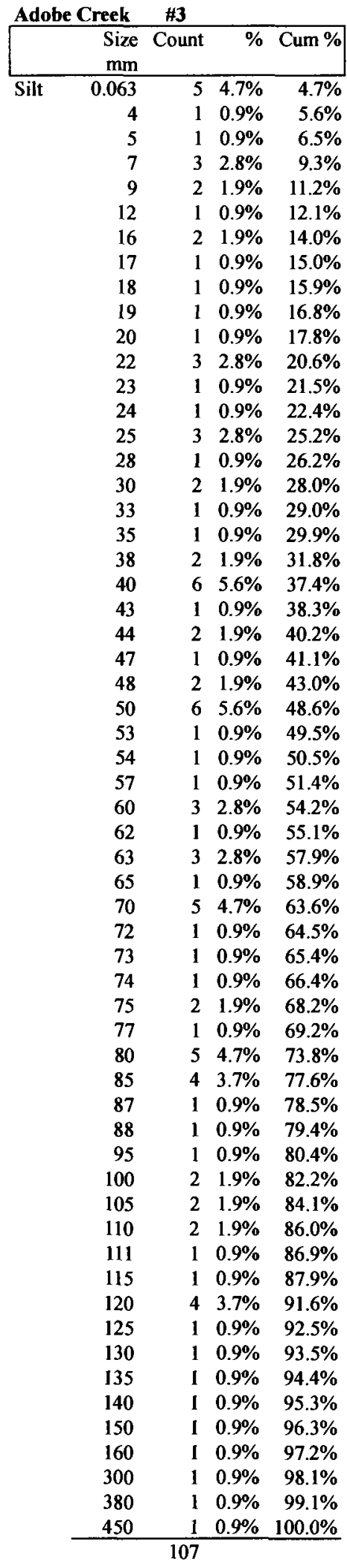

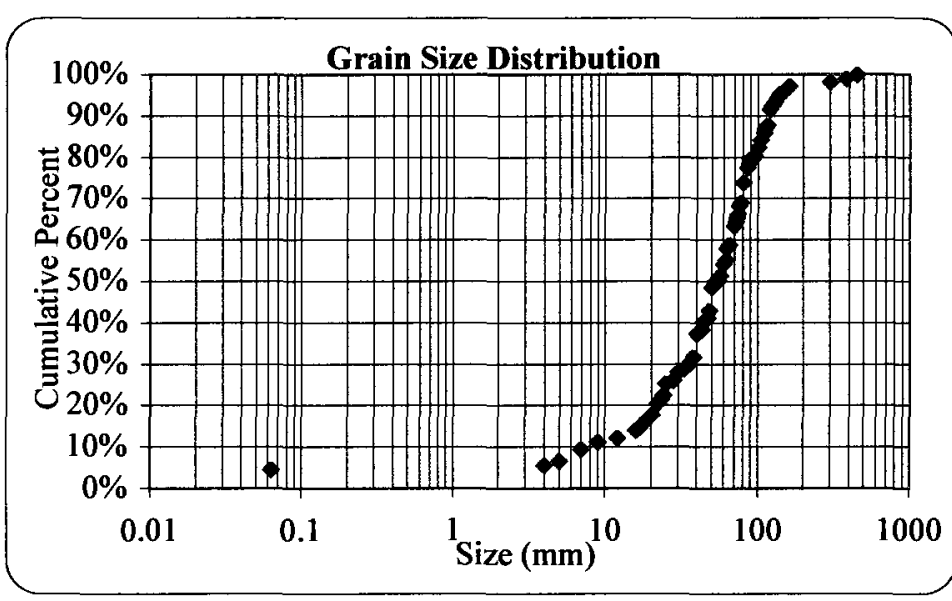

\begin{tabular}{|c|c|}
\hline Percentile & $\underline{\mathbf{m m}}$ \\
\hline d84 & 10 \\
\hline d50 & 5 \\
\hline d16 & 1 \\
\hline
\end{tabular}




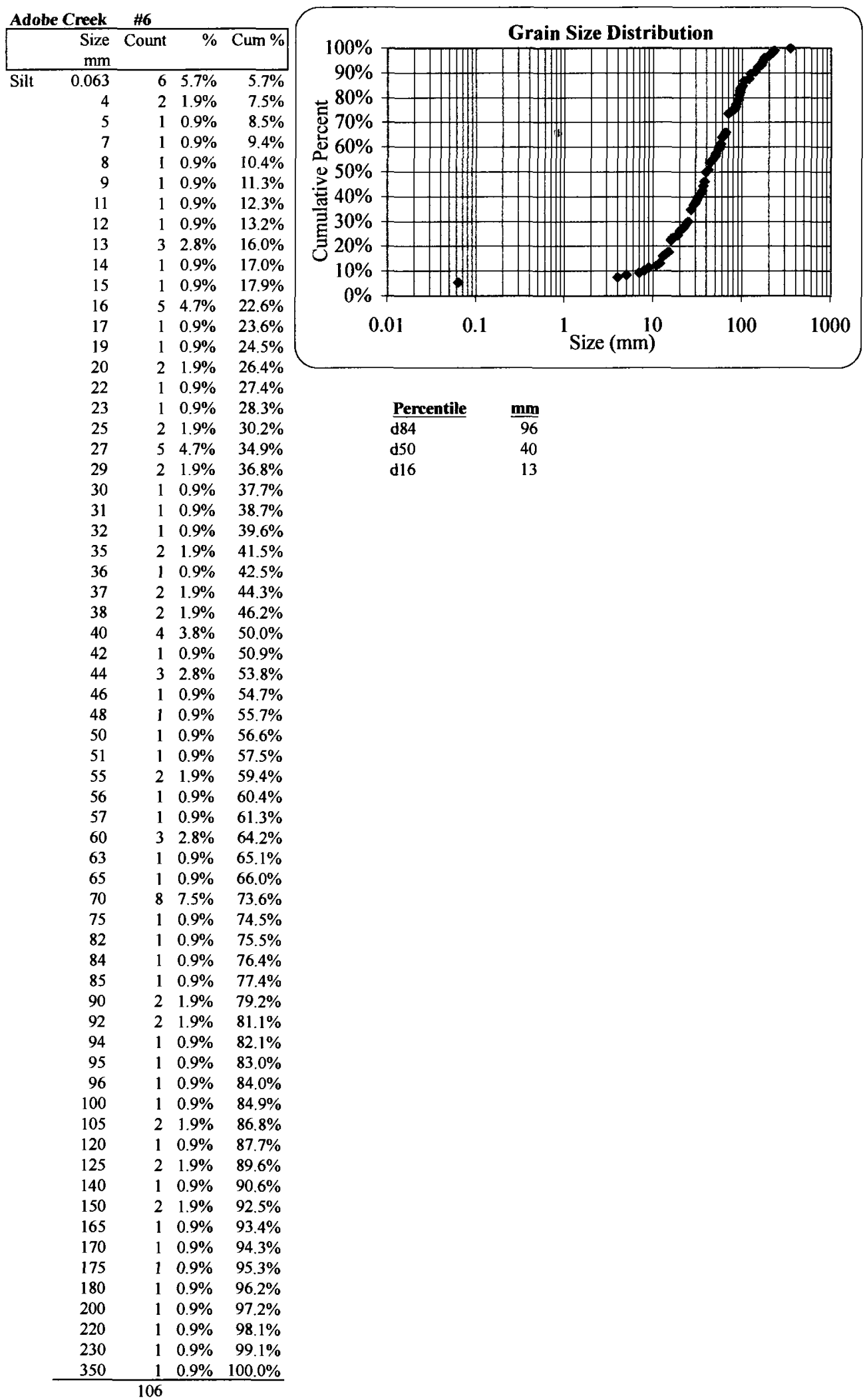




\begin{tabular}{|c|c|c|c|c|}
\hline \multicolumn{2}{|c|}{ Adobe Creek } & \multicolumn{3}{|c|}{$\# 7$} \\
\hline & \multicolumn{2}{|c|}{$\begin{array}{l}\text { Size Count } \\
\mathrm{mm}\end{array}$} & $\%$ & Cum \% \\
\hline \multirow[t]{61}{*}{ Silt } & 0.063 & 6 & $5.9 \%$ & $5.9 \%$ \\
\hline & 4 & 1 & $1.0 \%$ & $6.9 \%$ \\
\hline & 7 & 1 & $1.0 \%$ & $7.8 \%$ \\
\hline & 8 & 1 & $1.0 \%$ & $8.8 \%$ \\
\hline & 9 & 1 & $1.0 \%$ & $9.8 \%$ \\
\hline & 11 & 2 & $2.0 \%$ & $11.8 \%$ \\
\hline & 12 & 1 & $1.0 \%$ & $12.7 \%$ \\
\hline & 13 & 1 & $1.0 \%$ & $13.7 \%$ \\
\hline & 17 & 1 & $1.0 \%$ & $14.7 \%$ \\
\hline & 18 & 4 & $3.9 \%$ & $18.6 \%$ \\
\hline & 20 & 2 & $2.0 \%$ & $20.6 \%$ \\
\hline & 21 & 1 & $1.0 \%$ & $21.6 \%$ \\
\hline & 22 & 3 & $2.9 \%$ & $24.5 \%$ \\
\hline & 25 & 4 & $3.9 \%$ & $28.4 \%$ \\
\hline & 26 & 2 & $2.0 \%$ & $30.4 \%$ \\
\hline & 27 & 4 & $3.9 \%$ & $34.3 \%$ \\
\hline & 28 & 1 & $1.0 \%$ & $35.3 \%$ \\
\hline & 29 & 1 & $1.0 \%$ & $36.3 \%$ \\
\hline & 30 & 1 & $1.0 \%$ & $37.3 \%$ \\
\hline & 31 & 1 & $1.0 \%$ & $38.2 \%$ \\
\hline & 32 & 1 & $1.0 \%$ & $39.2 \%$ \\
\hline & 33 & 4 & $3.9 \%$ & $43.1 \%$ \\
\hline & 34 & 1 & $1.0 \%$ & $44.1 \%$ \\
\hline & 35 & 1 & $1.0 \%$ & $45.1 \%$ \\
\hline & 37 & 2 & $2.0 \%$ & $47.1 \%$ \\
\hline & 38 & 2 & $2.0 \%$ & $49.0 \%$ \\
\hline & 41 & 2 & $2.0 \%$ & $51.0 \%$ \\
\hline & 42 & 3 & $2.9 \%$ & $53.9 \%$ \\
\hline & 43 & 1 & $1.0 \%$ & $54.9 \%$ \\
\hline & 44 & 1 & $1.0 \%$ & $55.9 \%$ \\
\hline & 45 & 1 & $1.0 \%$ & $56.9 \%$ \\
\hline & 46 & 1 & $1.0 \%$ & $57.8 \%$ \\
\hline & 47 & 1 & $1.0 \%$ & $58.8 \%$ \\
\hline & 48 & 1 & $1.0 \%$ & $59.8 \%$ \\
\hline & 50 & 1 & $1.0 \%$ & $60.8 \%$ \\
\hline & 51 & 2 & $2.0 \%$ & $62.7 \%$ \\
\hline & 52 & 1 & $1.0 \%$ & $63.7 \%$ \\
\hline & 53 & 1 & $1.0 \%$ & $64.7 \%$ \\
\hline & 54 & $\mathbf{I}$ & $1.0 \%$ & $65.7 \%$ \\
\hline & 55 & 2 & $2.0 \%$ & $67.6 \%$ \\
\hline & 56 & 1 & $1.0 \%$ & $68.6 \%$ \\
\hline & 57 & 1 & $1.0 \%$ & $69.6 \%$ \\
\hline & 58 & 3 & $2.9 \%$ & $72.5 \%$ \\
\hline & 60 & 4 & $3.9 \%$ & $76.5 \%$ \\
\hline & 62 & 2 & $2.0 \%$ & $78.4 \%$ \\
\hline & 65 & 2 & $2.0 \%$ & $80.4 \%$ \\
\hline & 68 & 1 & $1.0 \%$ & $81.4 \%$ \\
\hline & 70 & 2 & $2.0 \%$ & $83.3 \%$ \\
\hline & 71 & 1 & $1.0 \%$ & $84.3 \%$ \\
\hline & 72 & 1 & $1.0 \%$ & $85.3 \%$ \\
\hline & 73 & 1 & $1.0 \%$ & $86.3 \%$ \\
\hline & 75 & 1 & $1.0 \%$ & $87.3 \%$ \\
\hline & 76 & 1 & $1.0 \%$ & $88.2 \%$ \\
\hline & 86 & 1 & $1.0 \%$ & $89.2 \%$ \\
\hline & 90 & 1 & $1.0 \%$ & $90.2 \%$ \\
\hline & 95 & 1 & $1.0 \%$ & $91.2 \%$ \\
\hline & 96 & 1 & $1.0 \%$ & $92.2 \%$ \\
\hline & 100 & 2 & $2.0 \%$ & $94.1 \%$ \\
\hline & 120 & 3 & $2.9 \%$ & $97.1 \%$ \\
\hline & 150 & 2 & $2.0 \%$ & $99.0 \%$ \\
\hline & 180 & 1 & $1.0 \%$ & $100.0 \%$ \\
\hline
\end{tabular}

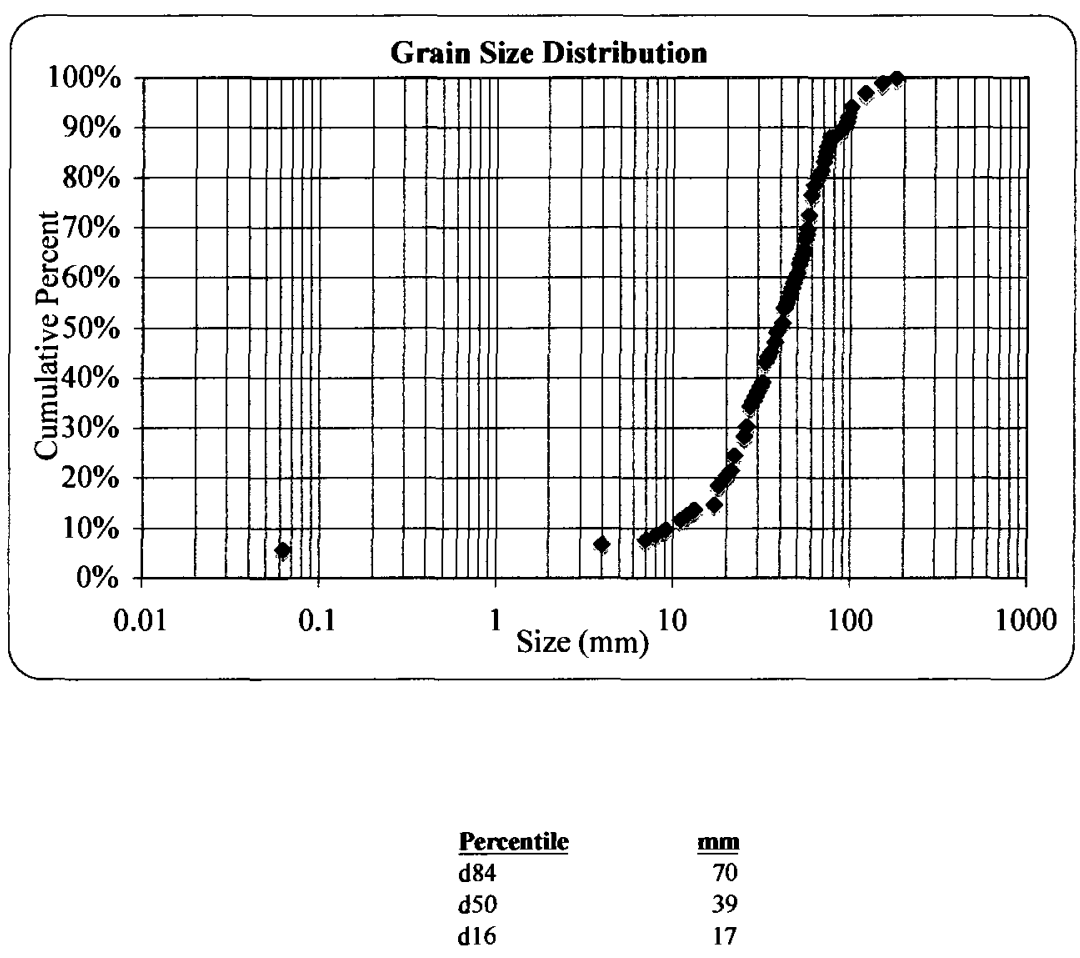




\begin{tabular}{|c|c|c|c|c|}
\hline Ado & reek & $\# 8$ & & \\
\hline & $\begin{array}{l}\text { Size } \\
\mathrm{mm}\end{array}$ & Count & $\%$ & Cum \% \\
\hline Silt & 0.063 & 3 & $3.1 \%$ & $3.1 \%$ \\
\hline & 4 & 1 & $1.0 \%$ & $4.1 \%$ \\
\hline & 6 & 1 & $1.0 \%$ & $5.2 \%$ \\
\hline & 10 & 9 & $9.3 \%$ & $14.4 \%$ \\
\hline & 14 & 1 & $1.0 \%$ & $15.5 \%$ \\
\hline & 15 & 7 & $7.2 \%$ & $22.7 \%$ \\
\hline & 16 & 1 & $1.0 \%$ & $23.7 \%$ \\
\hline & 17 & 1 & $1.0 \%$ & $24.7 \%$ \\
\hline & 18 & 1 & $1.0 \%$ & $25.8 \%$ \\
\hline & 19 & 2 & $2.1 \%$ & $27.8 \%$ \\
\hline & 20 & 17 & $17.5 \%$ & $45.4 \%$ \\
\hline & 21 & 1 & $1.0 \%$ & $46.4 \%$ \\
\hline & 22 & 3 & $3.1 \%$ & $49.5 \%$ \\
\hline & 24 & 1 & $1.0 \%$ & $50.5 \%$ \\
\hline & 25 & 10 & $10.3 \%$ & $60.8 \%$ \\
\hline & 26 & 1 & $1.0 \%$ & $61.9 \%$ \\
\hline & 27 & 1 & $1.0 \%$ & $62.9 \%$ \\
\hline & 28 & 1 & $1.0 \%$ & $63.9 \%$ \\
\hline & 30 & 14 & $14.4 \%$ & $78.4 \%$ \\
\hline & 31 & 1 & $1.0 \%$ & $79.4 \%$ \\
\hline & 32 & 1 & $1.0 \%$ & $80.4 \%$ \\
\hline & 35 & 2 & $2.1 \%$ & $82.5 \%$ \\
\hline & 40 & 5 & $5.2 \%$ & $87.6 \%$ \\
\hline & 42 & 1 & $1.0 \%$ & $88.7 \%$ \\
\hline & 45 & 1 & $1.0 \%$ & $89.7 \%$ \\
\hline & 50 & 2 & $2.1 \%$ & $91.8 \%$ \\
\hline & 55 & 1 & $1.0 \%$ & $92.8 \%$ \\
\hline & 60 & 2 & $2.1 \%$ & $94.8 \%$ \\
\hline & 65 & 1 & $1.0 \%$ & $95.9 \%$ \\
\hline & 68 & 1 & $1.0 \%$ & $96.9 \%$ \\
\hline & 80 & 2 & $2.1 \%$ & $99.0 \%$ \\
\hline & 120 & 1 & $1.0 \%$ & $100.0 \%$ \\
\hline
\end{tabular}

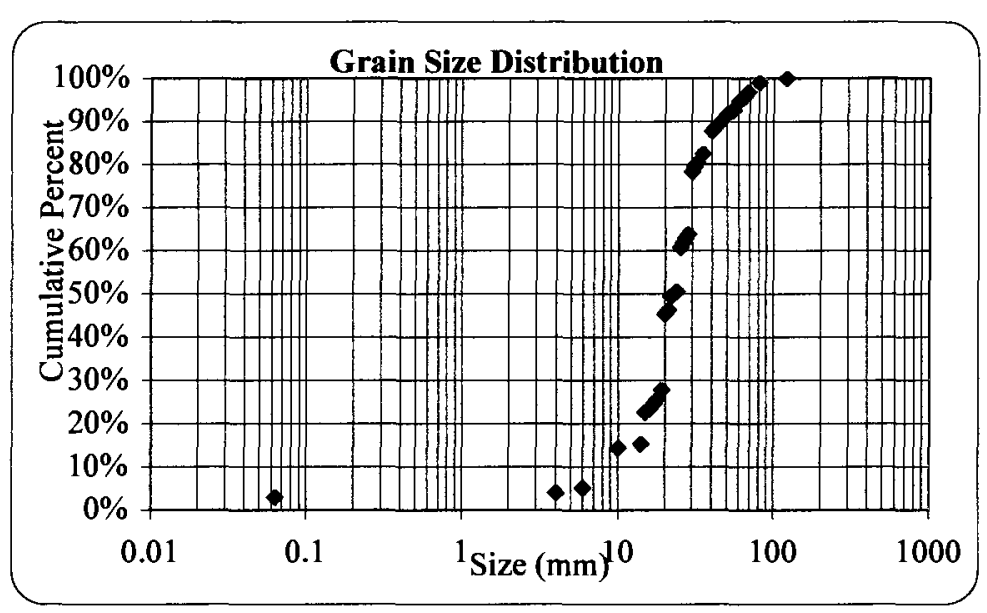

\begin{tabular}{lr} 
Percentile & mm \\
\cline { 1 - 2 } d84 & 36 \\
d50 & 23 \\
d16 & 14
\end{tabular}




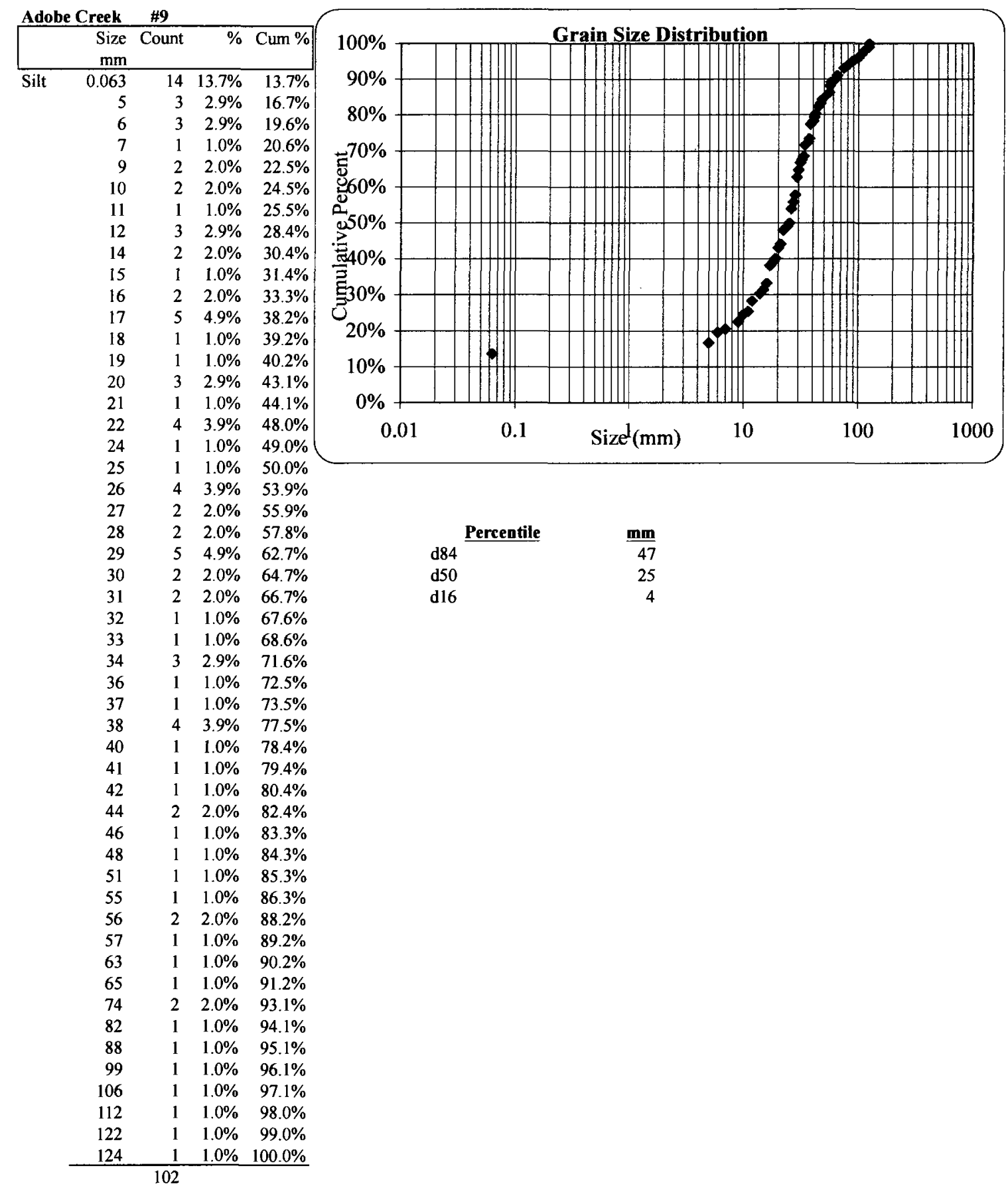




\begin{tabular}{|c|c|c|c|c|}
\hline Ado & Creek & $\# 10$ & & \\
\hline & $\begin{array}{l}\text { Size } \\
\mathrm{mm}\end{array}$ & Count & $\%$ & Cum \% \\
\hline Silt & 0.063 & $\overline{5}$ & $27.8 \%$ & $27.8 \%$ \\
\hline & 3 & 1 & $5.6 \%$ & $33.3 \%$ \\
\hline & 5 & 2 & $11.1 \%$ & $44.4 \%$ \\
\hline & 7 & 1 & $5.6 \%$ & $50.0 \%$ \\
\hline & 8 & 1 & $5.6 \%$ & $55.6 \%$ \\
\hline & 9 & 1 & $5.6 \%$ & $61.1 \%$ \\
\hline & 10 & 3 & $16.7 \%$ & $77.8 \%$ \\
\hline & 14 & 1 & $5.6 \%$ & $83.3 \%$ \\
\hline & 15 & 2 & $11.1 \%$ & $94.4 \%$ \\
\hline & 20 & 1 & $5.6 \%$ & $100.0 \%$ \\
\hline
\end{tabular}

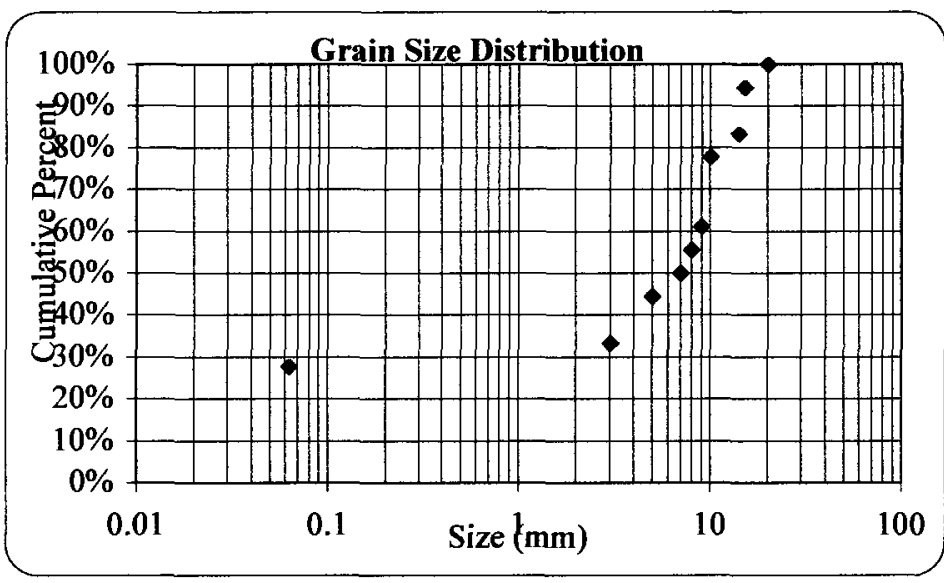

$\begin{array}{lr}\text { Percentile } & \begin{array}{ll}\text { mm } \\ \text { d84 }\end{array} \\ \text { d50 } & 74 \\ \text { d16 } & 0.063\end{array}$


Adobe Creeh \#10CC

\begin{tabular}{|c|c|c|c|c|}
\hline & $\begin{array}{l}\text { Size } \\
\text { mm }\end{array}$ & Count & $\%$ & Cum $\%$ \\
\hline Silt & 0.063 & 5 & $4.9 \%$ & $4.9 \%$ \\
\hline \multirow[t]{59}{*}{ Sand } & 1 & 10 & $9.7 \%$ & $14.6 \%$ \\
\hline & 2 & 1 & $1.0 \%$ & $15.5 \%$ \\
\hline & 3 & 3 & $2.9 \%$ & $18.4 \%$ \\
\hline & 4 & 3 & $2.9 \%$ & $21.4 \%$ \\
\hline & 5 & 2 & $1.9 \%$ & $23.3 \%$ \\
\hline & 6 & 5 & $4.9 \%$ & $28.2 \%$ \\
\hline & 8 & 2 & $1.9 \%$ & $30.1 \%$ \\
\hline & 9 & 2 & $1.9 \%$ & $32.0 \%$ \\
\hline & 10 & 1 & $1.0 \%$ & $33.0 \%$ \\
\hline & 11 & 2 & $1.9 \%$ & $35.0 \%$ \\
\hline & 12 & 3 & $2.9 \%$ & $37.9 \%$ \\
\hline & 13 & 2 & $1.9 \%$ & $39.8 \%$ \\
\hline & 14 & 1 & $1.0 \%$ & $40.8 \%$ \\
\hline & 15 & 3 & $2.9 \%$ & $43.7 \%$ \\
\hline & 16 & 1 & $1.0 \%$ & $44.7 \%$ \\
\hline & 17 & 1 & $1.0 \%$ & $45.6 \%$ \\
\hline & 18 & 1 & $1.0 \%$ & $46.6 \%$ \\
\hline & 19 & 2 & $1.9 \%$ & $48.5 \%$ \\
\hline & 20 & 1 & $1.0 \%$ & $49.5 \%$ \\
\hline & 21 & 3 & $2.9 \%$ & $52.4 \%$ \\
\hline & 22 & 1 & $1.0 \%$ & $53.4 \%$ \\
\hline & 23 & 1 & $1.0 \%$ & $54.4 \%$ \\
\hline & 24 & 4 & $3.9 \%$ & $58.3 \%$ \\
\hline & 26 & 1 & $1.0 \%$ & $59.2 \%$ \\
\hline & 28 & 1 & $1.0 \%$ & $60.2 \%$ \\
\hline & 29 & 2 & $1.9 \%$ & $62.1 \%$ \\
\hline & 31 & 2 & $1.9 \%$ & $64.1 \%$ \\
\hline & 32 & 1 & $1.0 \%$ & $65.0 \%$ \\
\hline & 33 & 1 & $1.0 \%$ & $66.0 \%$ \\
\hline & 34 & 1 & $1.0 \%$ & $67.0 \%$ \\
\hline & 38 & 3 & $2.9 \%$ & $69.9 \%$ \\
\hline & 42 & 1 & $1.0 \%$ & $70.9 \%$ \\
\hline & 45 & 1 & $1.0 \%$ & $71.8 \%$ \\
\hline & 48 & 2 & $1.9 \%$ & $73.8 \%$ \\
\hline & 52 & 2 & $1.9 \%$ & $75.7 \%$ \\
\hline & 54 & 1 & $1.0 \%$ & $76.7 \%$ \\
\hline & 55 & 1 & $1.0 \%$ & $77.7 \%$ \\
\hline & 58 & 1 & $1.0 \%$ & $78.6 \%$ \\
\hline & 62 & 1 & $1.0 \%$ & $79.6 \%$ \\
\hline & 66 & 1 & $1.0 \%$ & $80.6 \%$ \\
\hline & 68 & 1 & $1.0 \%$ & $81.6 \%$ \\
\hline & 69 & 1 & $1.0 \%$ & $82.5 \%$ \\
\hline & 72 & 1 & $1.0 \%$ & $83.5 \%$ \\
\hline & 73 & 1 & $1.0 \%$ & $84.5 \%$ \\
\hline & 75 & 1 & $1.0 \%$ & $85.4 \%$ \\
\hline & 80 & 1 & $1.0 \%$ & $86.4 \%$ \\
\hline & 82 & 1 & $1.0 \%$ & $87.4 \%$ \\
\hline & 83 & 1 & $1.0 \%$ & $88.3 \%$ \\
\hline & 85 & 1 & $1.0 \%$ & $89.3 \%$ \\
\hline & 98 & 1 & $1.0 \%$ & $90.3 \%$ \\
\hline & 107 & 1 & $1.0 \%$ & $91.3 \%$ \\
\hline & 110 & 2 & $1.9 \%$ & $93.2 \%$ \\
\hline & 120 & 1 & $1.0 \%$ & $94.2 \%$ \\
\hline & 132 & 1 & $1.0 \%$ & $95.1 \%$ \\
\hline & 135 & 1 & $1.0 \%$ & $96.1 \%$ \\
\hline & 155 & 1 & $1.0 \%$ & $97.1 \%$ \\
\hline & 163 & 1 & $1.0 \%$ & $98.1 \%$ \\
\hline & 170 & 1 & $1.0 \%$ & $99.0 \%$ \\
\hline & 210 & 1 & $1.0 \%$ & $100.0 \%$ \\
\hline
\end{tabular}

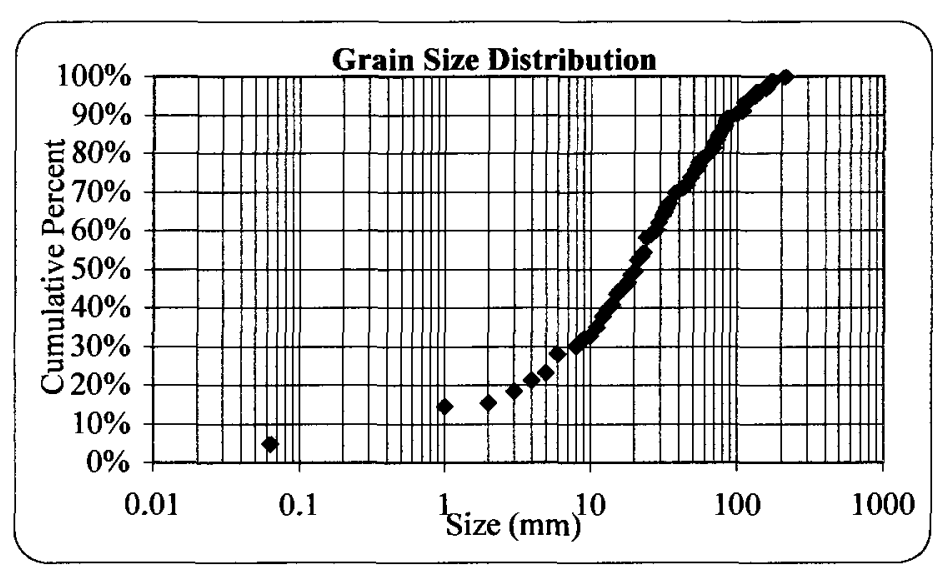

$\begin{array}{lr}\text { Percentile } & \frac{\mathrm{mm}}{\mathrm{d} 84} \\ \mathrm{~d} 50 & 36 \\ \mathrm{~d} 16 & 23 \\ & 2\end{array}$




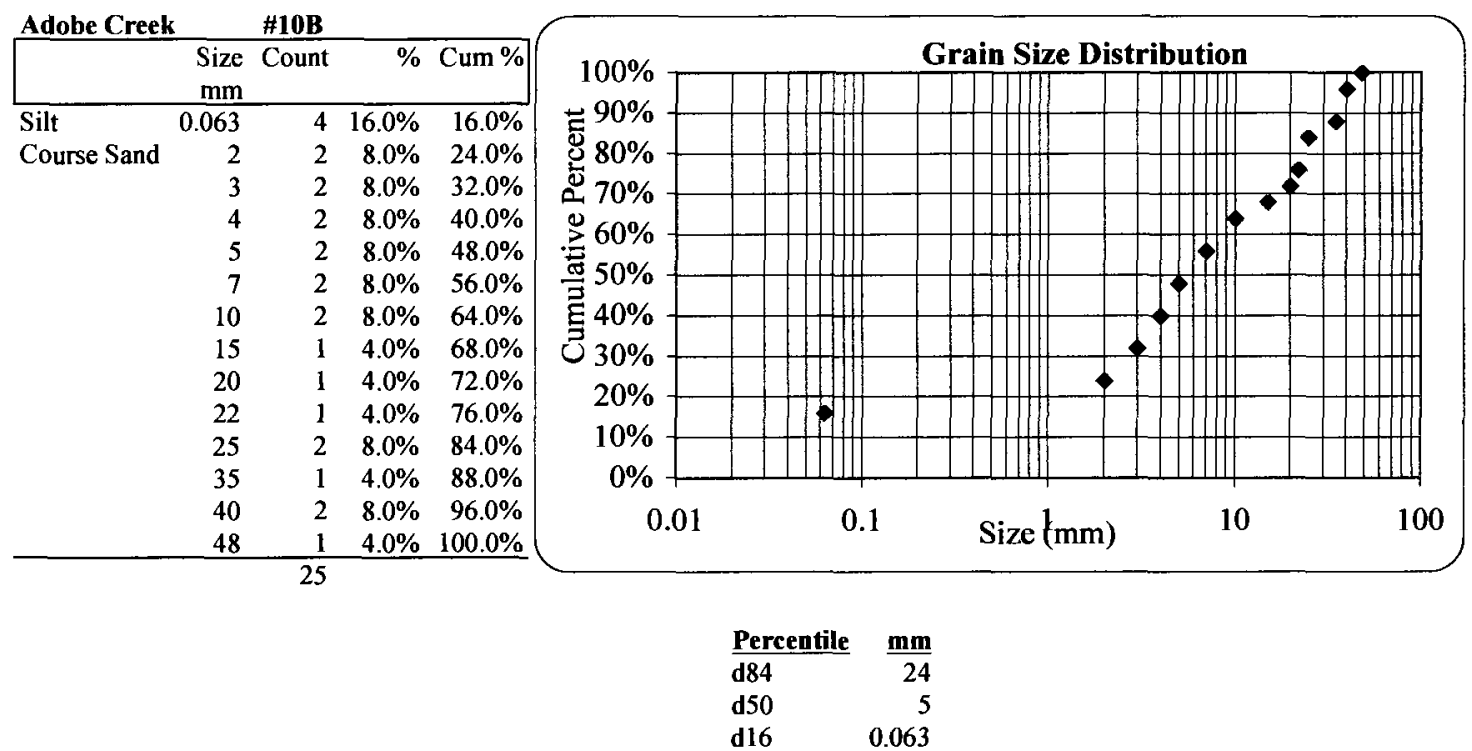




\begin{tabular}{|c|c|c|c|c|}
\hline \multicolumn{2}{|c|}{ Adobe Creek } & \multicolumn{3}{|l|}{ \#10BB } \\
\hline & $\begin{array}{l}\text { Size } \\
\mathrm{mm}\end{array}$ & Count & $\%$ & Cum \% \\
\hline Silt & 0.063 & 10 & $10.1 \%$ & $10.1 \%$ \\
\hline Fine Sand & 1 & 2 & $2.0 \%$ & $12.1 \%$ \\
\hline & 2 & 4 & $4.0 \%$ & $16.2 \%$ \\
\hline & 3 & I & $1.0 \%$ & $17.2 \%$ \\
\hline & 4 & 1 & $1.0 \%$ & $18.2 \%$ \\
\hline & 5 & 1 & $1.0 \%$ & $19.2 \%$ \\
\hline & 6 & 2 & $2.0 \%$ & $21.2 \%$ \\
\hline & 7 & 3 & $3.0 \%$ & $24.2 \%$ \\
\hline & 8 & 1 & $1.0 \%$ & $25.3 \%$ \\
\hline & 9 & 1 & $1.0 \%$ & $26.3 \%$ \\
\hline & 10 & 1 & $1.0 \%$ & $27.3 \%$ \\
\hline & 11 & 1 & $1.0 \%$ & $28.3 \%$ \\
\hline & 12 & 5 & $5.1 \%$ & $33.3 \%$ \\
\hline & 13 & 2 & $2.0 \%$ & $35.4 \%$ \\
\hline & 14 & 1 & $1.0 \%$ & $36.4 \%$ \\
\hline & 15 & 3 & $3.0 \%$ & $39.4 \%$ \\
\hline & 17 & 4 & $4.0 \%$ & $43.4 \%$ \\
\hline & 18 & 4 & $4.0 \%$ & $47.5 \%$ \\
\hline & 19 & 4 & $4.0 \%$ & $51.5 \%$ \\
\hline & 20 & 2 & $2.0 \%$ & $53.5 \%$ \\
\hline & 21 & 2 & $2.0 \%$ & $55.6 \%$ \\
\hline & 22 & 1 & $1.0 \%$ & $56.6 \%$ \\
\hline & 26 & 2 & $2.0 \%$ & $58.6 \%$ \\
\hline & 28 & 3 & $3.0 \%$ & $61.6 \%$ \\
\hline & 30 & 2 & $2.0 \%$ & $63.6 \%$ \\
\hline & 32 & 1 & $1.0 \%$ & $64.6 \%$ \\
\hline & 35 & 1 & $1.0 \%$ & $65.7 \%$ \\
\hline & 36 & 1 & $1.0 \%$ & $66.7 \%$ \\
\hline & 38 & 1 & $1.0 \%$ & $67.7 \%$ \\
\hline & 40 & 1 & $1.0 \%$ & $68.7 \%$ \\
\hline & 41 & 1 & $1.0 \%$ & $69.7 \%$ \\
\hline & 42 & 2 & $2.0 \%$ & $71.7 \%$ \\
\hline & 43 & 1 & $1.0 \%$ & $72.7 \%$ \\
\hline & 44 & 2 & $2.0 \%$ & $74.7 \%$ \\
\hline & 46 & 1 & $1.0 \%$ & $75.8 \%$ \\
\hline & 49 & 2 & $2.0 \%$ & $77.8 \%$ \\
\hline & 51 & 1 & $1.0 \%$ & $78.8 \%$ \\
\hline & 52 & 2 & $2.0 \%$ & $80.8 \%$ \\
\hline & 53 & 1 & $1.0 \%$ & $81.8 \%$ \\
\hline & 54 & 1 & $1.0 \%$ & $82.8 \%$ \\
\hline & 59 & 2 & $2.0 \%$ & $84.8 \%$ \\
\hline & 61 & 1 & $1.0 \%$ & $85.9 \%$ \\
\hline & 65 & 1 & $1.0 \%$ & $86.9 \%$ \\
\hline & 68 & 2 & $2.0 \%$ & $88.9 \%$ \\
\hline & 73 & 1 & $1.0 \%$ & $89.9 \%$ \\
\hline & 74 & 1 & $1.0 \%$ & $90.9 \%$ \\
\hline & 76 & 3 & $3.0 \%$ & $93.9 \%$ \\
\hline & 77 & 1 & $1.0 \%$ & $94.9 \%$ \\
\hline & 82 & 1 & $1.0 \%$ & $96.0 \%$ \\
\hline & 91 & 1 & $1.0 \%$ & $97.0 \%$ \\
\hline & 102 & 1 & $1.0 \%$ & $98.0 \%$ \\
\hline & 105 & 1 & $1.0 \%$ & $99.0 \%$ \\
\hline & 132 & 1 & $1.0 \%$ & $100.0 \%$ \\
\hline
\end{tabular}

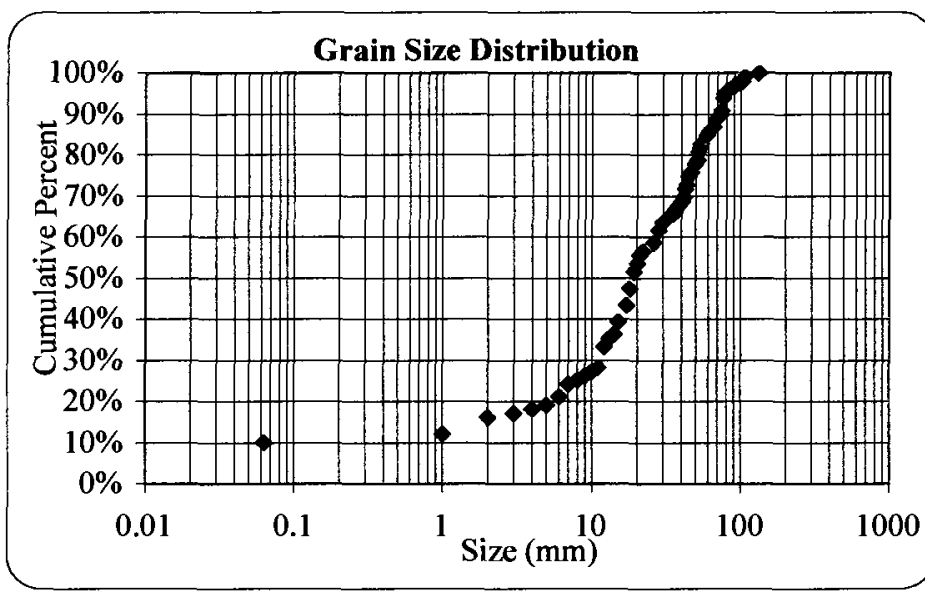

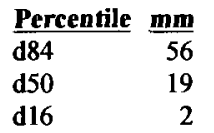




\begin{tabular}{|c|c|c|c|c|}
\hline Adobe Creek & & $\# 10 \mathrm{C}$ & & \\
\hline & $\begin{array}{l}\text { Size } \\
\mathrm{mm}\end{array}$ & Count & $\%$ & Cum \% \\
\hline Silt & 0.063 & 2 & $7.1 \%$ & $7.1 \%$ \\
\hline Course Sand & 2 & 4 & $14.3 \%$ & $21.4 \%$ \\
\hline & 3 & 2 & $7.1 \%$ & $28.6 \%$ \\
\hline & 4 & 1 & $3.6 \%$ & $32.1 \%$ \\
\hline & 5 & 4 & $14.3 \%$ & $46.4 \%$ \\
\hline & 7 & 1 & $3.6 \%$ & $50.0 \%$ \\
\hline & 8 & 1 & $3.6 \%$ & $53.6 \%$ \\
\hline & 10 & 4 & $14.3 \%$ & $67.9 \%$ \\
\hline & 10 & 3 & $10.7 \%$ & $78.6 \%$ \\
\hline & 15 & 1 & $3.6 \%$ & $82.1 \%$ \\
\hline & 17 & 1 & $3.6 \%$ & $85.7 \%$ \\
\hline & 30 & 1 & $3.6 \%$ & $89.3 \%$ \\
\hline & 40 & 1 & $3.6 \%$ & $92.9 \%$ \\
\hline & 70 & 1 & $3.6 \%$ & $96.4 \%$ \\
\hline & 90 & 1 & $3.6 \%$ & $100.0 \%$ \\
\hline
\end{tabular}

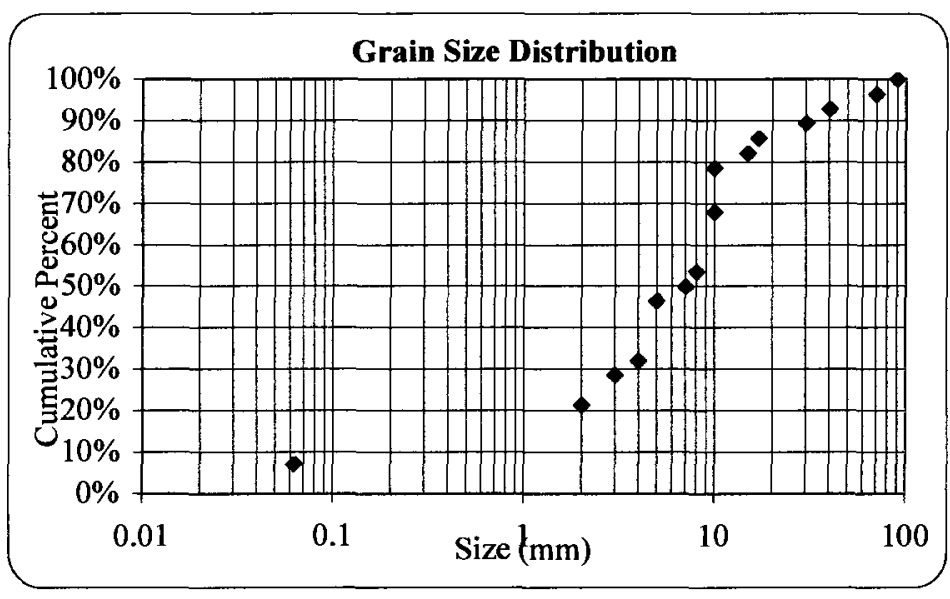

$\begin{array}{lr}\text { Percentile } & \frac{\text { mm }}{\text { d84 }} \\ \text { d50 } & 7 \\ \text { d16 } & 1\end{array}$




\begin{tabular}{|c|c|c|c|c|}
\hline 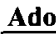 & Creek & $\# 11$ & & \\
\hline & $\begin{array}{l}\text { Size } \\
\text { mm }\end{array}$ & Count & $\%$ & Cum \% \\
\hline Silt & 0.063 & 2 & $16.7 \%$ & $16.7 \%$ \\
\hline & 2 & 1 & $8.3 \%$ & $25.0 \%$ \\
\hline & 3 & 1 & $8.3 \%$ & $33.3 \%$ \\
\hline & 8 & 1 & $8.3 \%$ & $41.7 \%$ \\
\hline & 10 & 2 & $16.7 \%$ & $58.3 \%$ \\
\hline & 19 & 1 & $8.3 \%$ & $66.7 \%$ \\
\hline & 19 & 2 & $16.7 \%$ & $83.3 \%$ \\
\hline & 30 & 1 & $8.3 \%$ & $91.7 \%$ \\
\hline & 40 & 1 & $8.3 \%$ & $100.0 \%$ \\
\hline
\end{tabular}

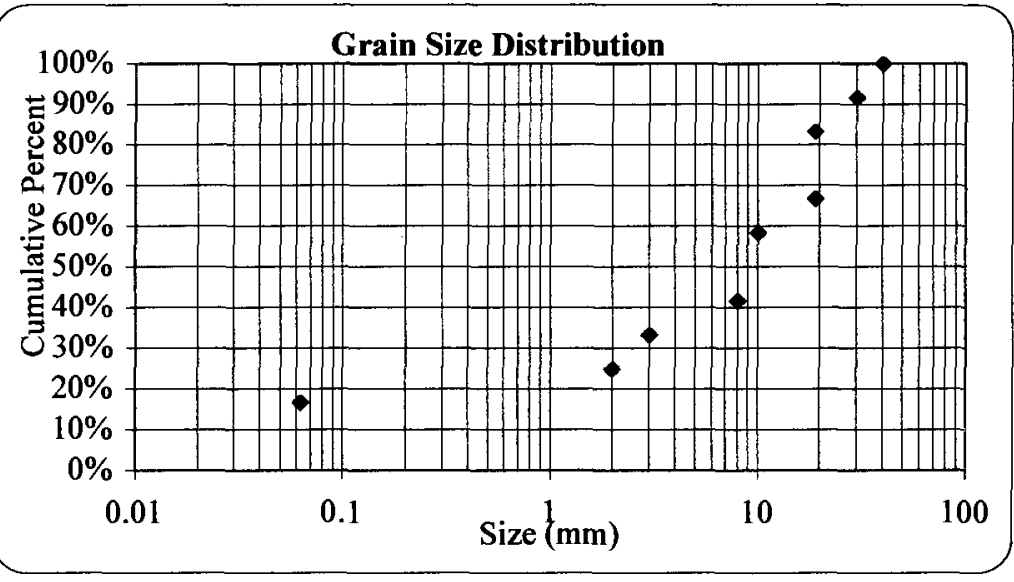

\begin{tabular}{|c|c|}
\hline Percentile & $\underline{\mathrm{mm}}$ \\
\hline $\mathrm{d84}$ & 19 \\
\hline d50 & \\
\hline d16 & 0.06 \\
\hline
\end{tabular}




\begin{tabular}{|c|c|c|c|c|}
\hline \multirow[t]{2}{*}{ Adobe Creek } & \multicolumn{4}{|c|}{ \#11-2 } \\
\hline & $\begin{array}{r}\text { Size } \\
\text { mm }\end{array}$ & Count & $\%$ & Cum \% \\
\hline Silt & 0.063 & 4 & $17.4 \%$ & $17.4 \%$ \\
\hline \multirow[t]{12}{*}{ Course Sand } & 2 & 5 & $21.7 \%$ & $39.1 \%$ \\
\hline & 3 & 1 & $4.3 \%$ & $43.5 \%$ \\
\hline & 4 & 2 & $8.7 \%$ & $52.2 \%$ \\
\hline & 5 & 1 & $4.3 \%$ & $56.5 \%$ \\
\hline & 6 & 1 & $4.3 \%$ & $60.9 \%$ \\
\hline & 10 & 3 & $13.0 \%$ & $73.9 \%$ \\
\hline & 20 & 1 & $4.3 \%$ & $78.3 \%$ \\
\hline & 23 & 1 & $4.3 \%$ & $82.6 \%$ \\
\hline & 25 & 1 & $4.3 \%$ & $87.0 \%$ \\
\hline & 30 & 1 & $4.3 \%$ & $91.3 \%$ \\
\hline & 50 & 1 & $4.3 \%$ & $95.7 \%$ \\
\hline & 70 & 1 & $4.3 \%$ & $100.0 \%$ \\
\hline
\end{tabular}

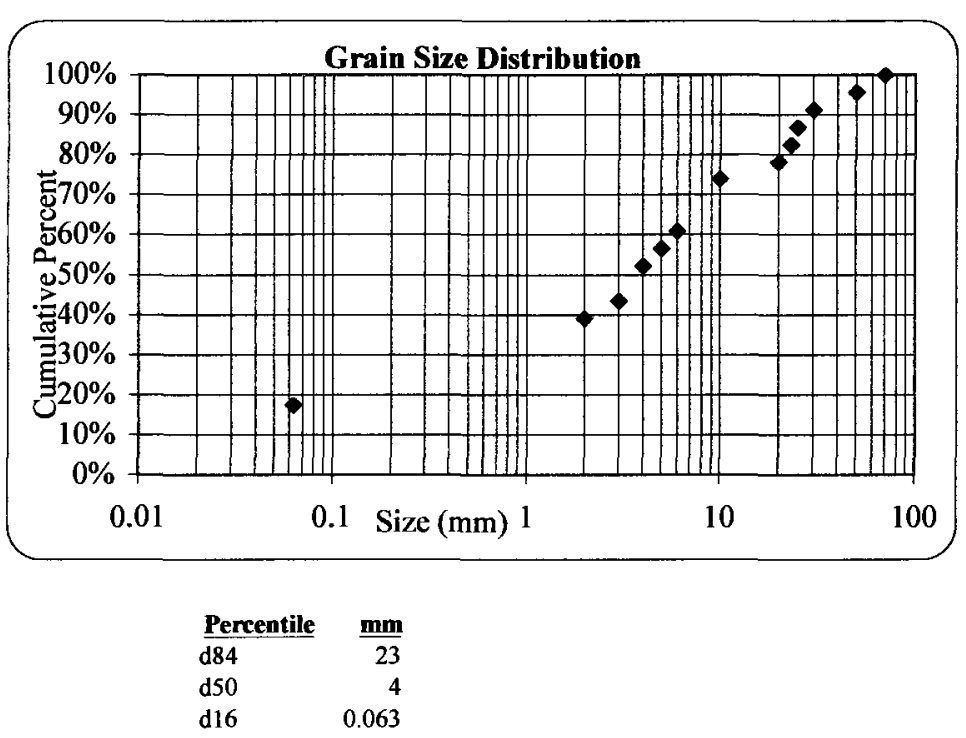




\begin{tabular}{|c|c|c|c|c|}
\hline \multirow[t]{2}{*}{ Adobe Creek } & \multicolumn{4}{|c|}{$\# 12 \mathrm{~A}$} \\
\hline & $\begin{array}{c}\text { Size } \\
\mathrm{mm}\end{array}$ & Count & $\%$ & Cum \% \\
\hline Silt & 0.06 & 2 & $16.7 \%$ & $16.7 \%$ \\
\hline Course Sand & 2 & 2 & $16.7 \%$ & $33.3 \%$ \\
\hline & 3 & 1 & $8.3 \%$ & $41.7 \%$ \\
\hline & 4 & 1 & $8.3 \%$ & $50.0 \%$ \\
\hline & 6 & 1 & $8.3 \%$ & $58.3 \%$ \\
\hline & 7 & 1 & $8.3 \%$ & $66.7 \%$ \\
\hline & 8 & 1 & $8.3 \%$ & $75.0 \%$ \\
\hline & 14 & 1 & $8.3 \%$ & $83.3 \%$ \\
\hline & 20 & 1 & $8.3 \%$ & $91.7 \%$ \\
\hline & 25 & 1 & $8.3 \%$ & $100.0 \%$ \\
\hline
\end{tabular}

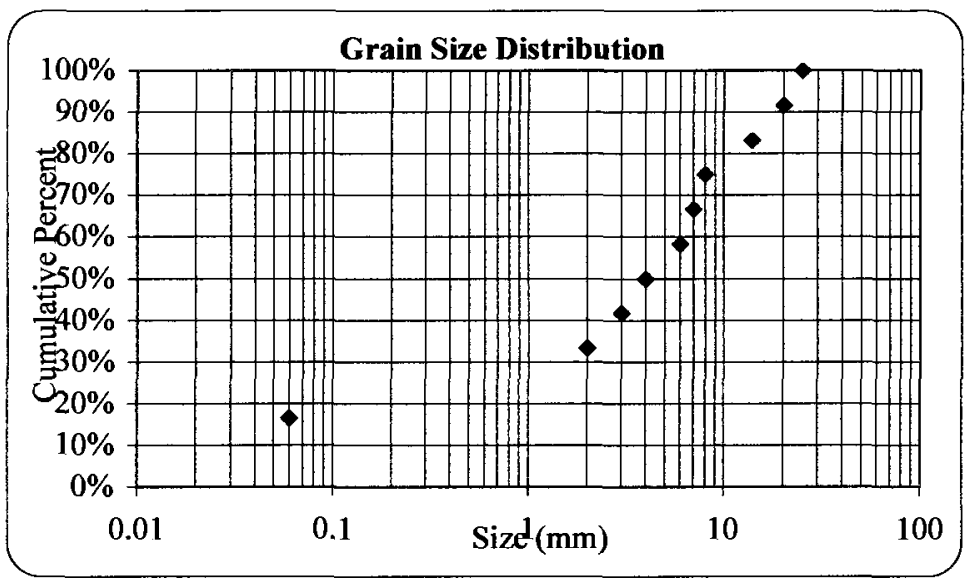

\begin{tabular}{|c|c|}
\hline Percentile & $\mathbf{m m}$ \\
\hline $\mathrm{d} 84$ & 14 \\
\hline $\mathrm{d} 50$ & 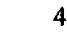 \\
\hline $\mathrm{d} 16$ & 0.063 \\
\hline
\end{tabular}




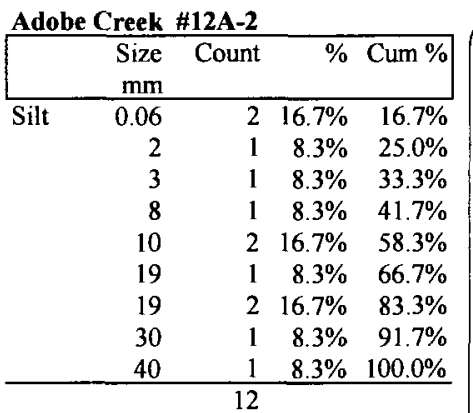

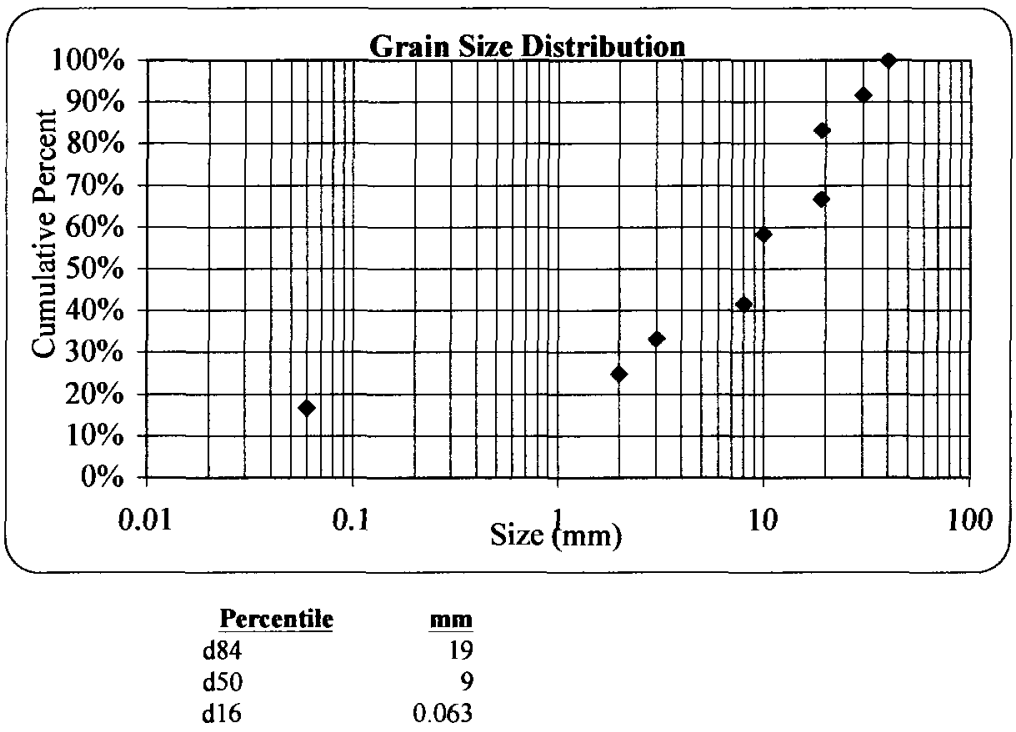




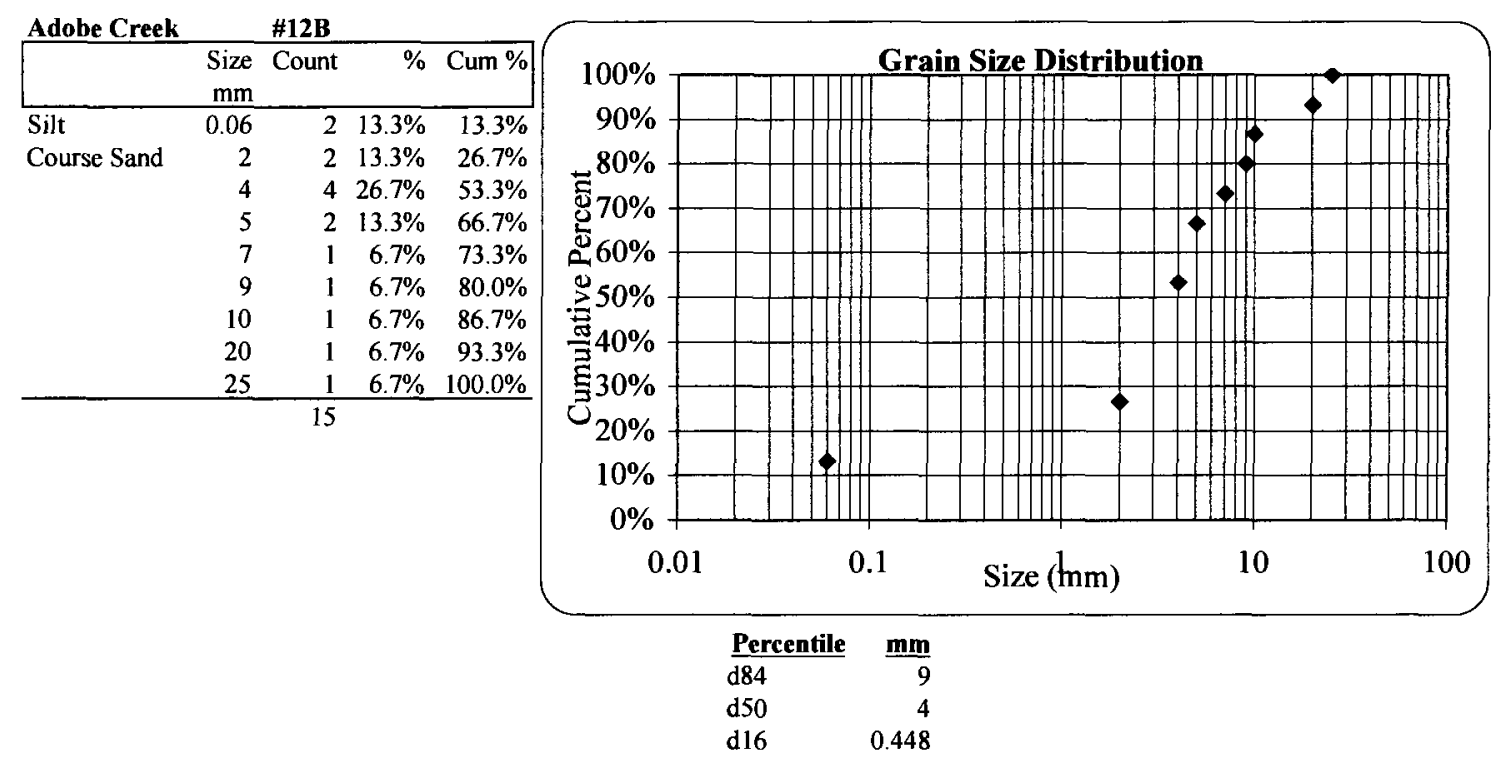




\begin{tabular}{|lrrrr|}
\hline Adobe Creek & \multicolumn{3}{c|}{ \#12C } & \\
& $\begin{array}{l}\text { Size } \\
\text { mm }\end{array}$ & & & \\
\hline Silt & 0.063 & 4 & $25.0 \%$ & $25.0 \%$ \\
Sand & 1 & 1 & $6.3 \%$ & $31.3 \%$ \\
Course Sand & 2 & 3 & $18.8 \%$ & $50.0 \%$ \\
& 3 & 1 & $6.3 \%$ & $56.3 \%$ \\
& 5 & 1 & $6.3 \%$ & $62.5 \%$ \\
& 10 & 3 & $18.8 \%$ & $81.3 \%$ \\
& 15 & 2 & $12.5 \%$ & $93.8 \%$ \\
& 35 & 1 & $6.3 \%$ & $100.0 \%$ \\
\hline
\end{tabular}

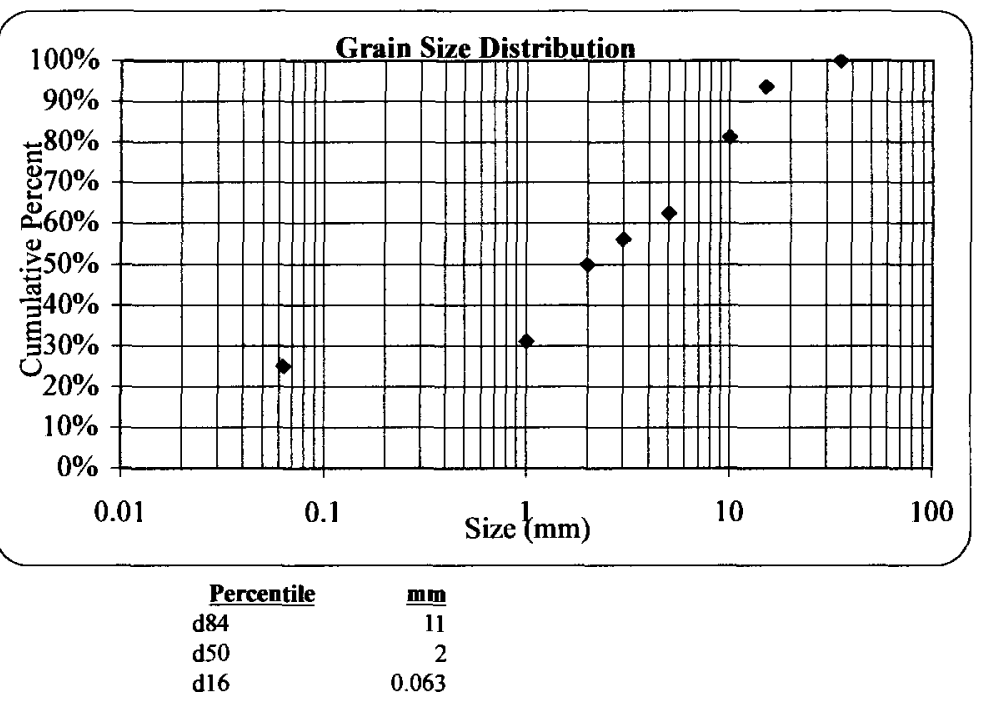




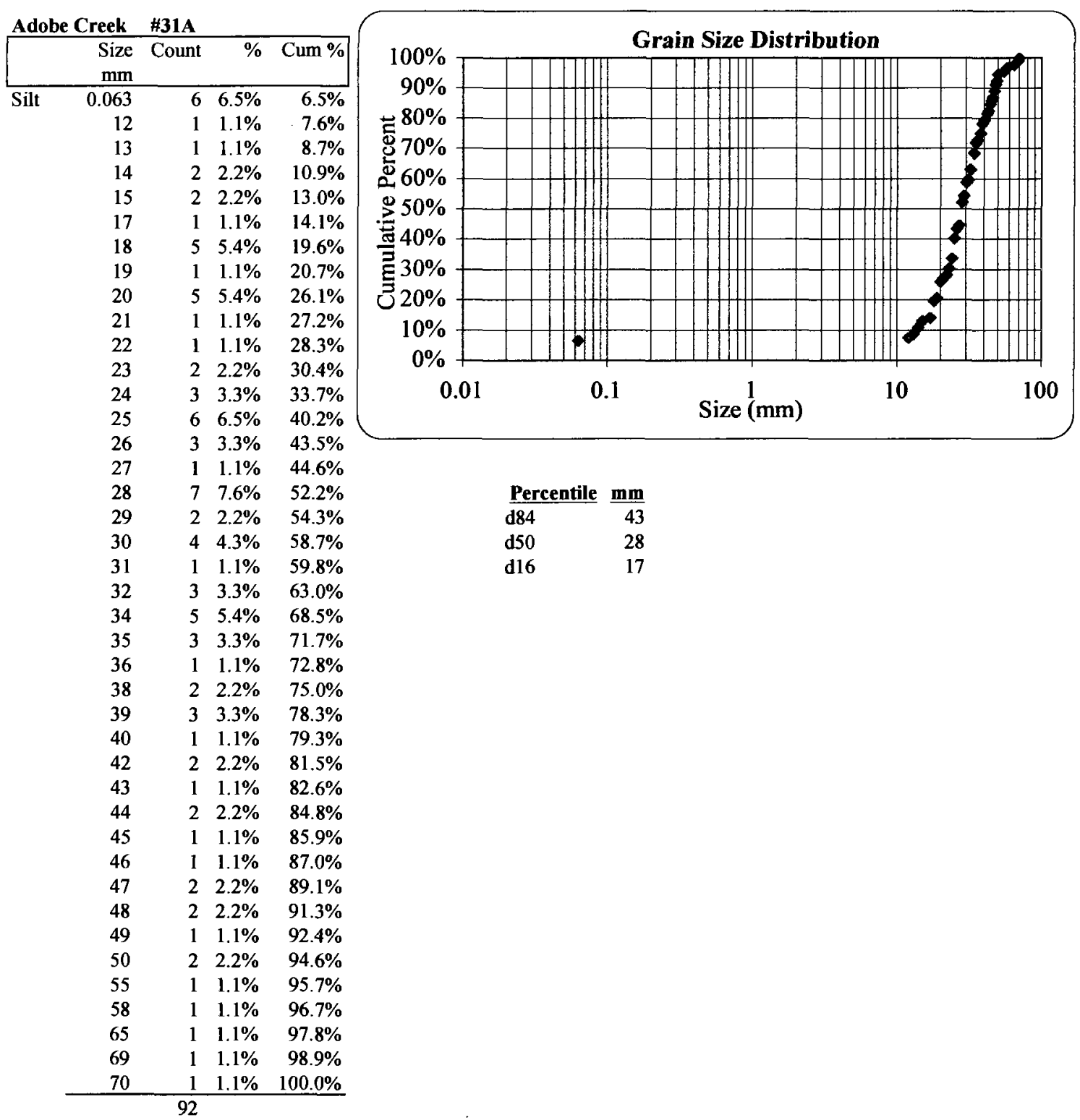




\begin{tabular}{|c|c|c|c|c|}
\hline \multicolumn{2}{|c|}{ Adobe Creek } & \multicolumn{3}{|l|}{ \#32 } \\
\hline & $\begin{array}{l}\text { Size } \\
\mathrm{mm}\end{array}$ & Count & $\%$ & Cum \% \\
\hline \multirow{34}{*}{ Silt } & 0.063 & 22 & $25.9 \%$ & $25.9 \%$ \\
\hline & 11 & 1 & $1.2 \%$ & $27.1 \%$ \\
\hline & 14 & 1 & $1.2 \%$ & $28.2 \%$ \\
\hline & 16 & 2 & $2.4 \%$ & $30.6 \%$ \\
\hline & 18 & 2 & $2.4 \%$ & $32.9 \%$ \\
\hline & 20 & 2 & $2.4 \%$ & $35.3 \%$ \\
\hline & 21 & 2 & $2.4 \%$ & $37.6 \%$ \\
\hline & 22 & 4 & $4.7 \%$ & $42.4 \%$ \\
\hline & 23 & 2 & $2.4 \%$ & $44.7 \%$ \\
\hline & 24 & 2 & $2.4 \%$ & $47.1 \%$ \\
\hline & 25 & 2 & $2.4 \%$ & $49.4 \%$ \\
\hline & 26 & 2 & $2.4 \%$ & $51.8 \%$ \\
\hline & 28 & 1 & $1.2 \%$ & $52.9 \%$ \\
\hline & 29 & 3 & $3.5 \%$ & $56.5 \%$ \\
\hline & 32 & 2 & $2.4 \%$ & $58.8 \%$ \\
\hline & 33 & 2 & $2.4 \%$ & $61.2 \%$ \\
\hline & 34 & 2 & $2.4 \%$ & $63.5 \%$ \\
\hline & 35 & 1 & $1.2 \%$ & $64.7 \%$ \\
\hline & 36 & 5 & $5.9 \%$ & $70.6 \%$ \\
\hline & 37 & 2 & $2.4 \%$ & $72.9 \%$ \\
\hline & 38 & 2 & $2.4 \%$ & $75.3 \%$ \\
\hline & 39 & 2 & $2.4 \%$ & $77.6 \%$ \\
\hline & 40 & 2 & $2.4 \%$ & $80.0 \%$ \\
\hline & 42 & 2 & $2.4 \%$ & $82.4 \%$ \\
\hline & 43 & 2 & $2.4 \%$ & $84.7 \%$ \\
\hline & 44 & 2 & $2.4 \%$ & $87.1 \%$ \\
\hline & 45 & 1 & $1.2 \%$ & $88.2 \%$ \\
\hline & 46 & 1 & $1.2 \%$ & $89.4 \%$ \\
\hline & 50 & 1 & $1.2 \%$ & $90.6 \%$ \\
\hline & 54 & 4 & $4.7 \%$ & $95.3 \%$ \\
\hline & 56 & 1 & $1.2 \%$ & $96.5 \%$ \\
\hline & 62 & 1 & $1.2 \%$ & $97.6 \%$ \\
\hline & 70 & 1 & $1.2 \%$ & $98.8 \%$ \\
\hline & 74 & 1 & $1.2 \%$ & $100.0 \%$ \\
\hline
\end{tabular}

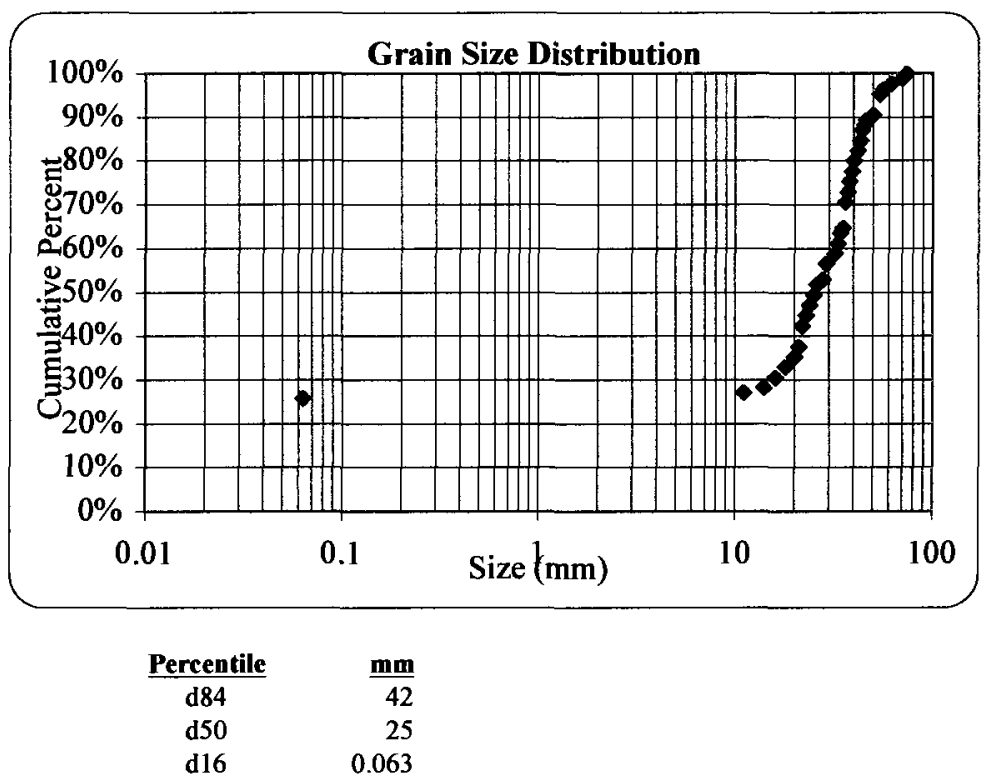




\begin{tabular}{|c|c|c|c|c|}
\hline $\mathrm{AO}$ & reek & \#35 & & \\
\hline & $\begin{array}{l}\text { Size } \\
\text { mm }\end{array}$ & Count & $\%$ & Cum $\%$ \\
\hline Silt & 0.063 & 7 & $7.0 \%$ & $7.0 \%$ \\
\hline & 1 & 6 & $6.0 \%$ & $13.0 \%$ \\
\hline & 2 & 11 & $11.0 \%$ & $24.0 \%$ \\
\hline & 3 & 2 & $2.0 \%$ & $26.0 \%$ \\
\hline & 4 & 5 & $5.0 \%$ & $31.0 \%$ \\
\hline & 5 & 7 & $7.0 \%$ & $38.0 \%$ \\
\hline & 6 & 5 & $5.0 \%$ & $43.0 \%$ \\
\hline & 7 & 4 & $4.0 \%$ & $47.0 \%$ \\
\hline & 8 & 4 & $4.0 \%$ & $51.0 \%$ \\
\hline & 9 & 5 & $5.0 \%$ & $56.0 \%$ \\
\hline & 10 & 4 & $4.0 \%$ & $60.0 \%$ \\
\hline & 11 & 5 & $5.0 \%$ & $65.0 \%$ \\
\hline & 12 & 2 & $2.0 \%$ & $67.0 \%$ \\
\hline & 13 & 2 & $2.0 \%$ & $69.0 \%$ \\
\hline & 14 & 4 & $4.0 \%$ & $73.0 \%$ \\
\hline & 15 & 3 & $3.0 \%$ & $76.0 \%$ \\
\hline & 16 & 5 & $5.0 \%$ & $81.0 \%$ \\
\hline & 18 & 4 & $4.0 \%$ & $85.0 \%$ \\
\hline & 19 & 1 & $1.0 \%$ & $86.0 \%$ \\
\hline & 20 & 2 & $2.0 \%$ & $88.0 \%$ \\
\hline & 21 & 1 & $1.0 \%$ & $89.0 \%$ \\
\hline & 23 & 1 & $1.0 \%$ & $90.0 \%$ \\
\hline & 26 & 1 & $1.0 \%$ & $91.0 \%$ \\
\hline & 29 & 2 & $2.0 \%$ & $93.0 \%$ \\
\hline & 30 & 1 & $1.0 \%$ & $94.0 \%$ \\
\hline & 31 & 2 & $2.0 \%$ & $96.0 \%$ \\
\hline & 36 & 1 & $1.0 \%$ & $97.0 \%$ \\
\hline & 38 & 1 & $1.0 \%$ & $98.0 \%$ \\
\hline & 41 & 1 & $1.0 \%$ & $99.0 \%$ \\
\hline & 54 & 1 & $1.0 \%$ & $100.0 \%$ \\
\hline
\end{tabular}

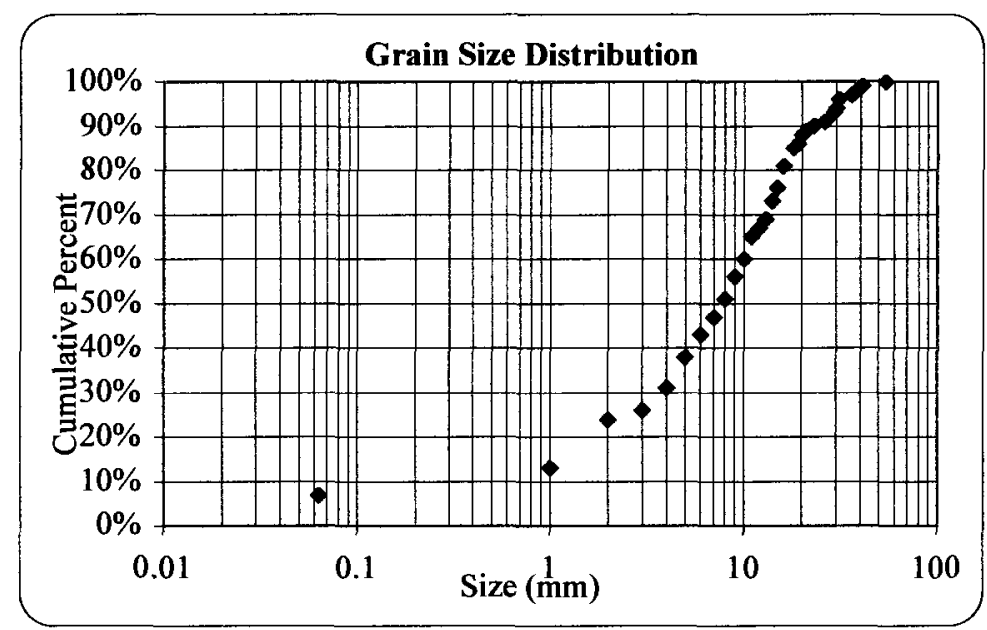

$\begin{array}{lr}\text { Percentile } & \mathrm{mm} \\ \text { d84 } & 17 \\ \text { d50 } & 8 \\ \text { d16 } & 1\end{array}$




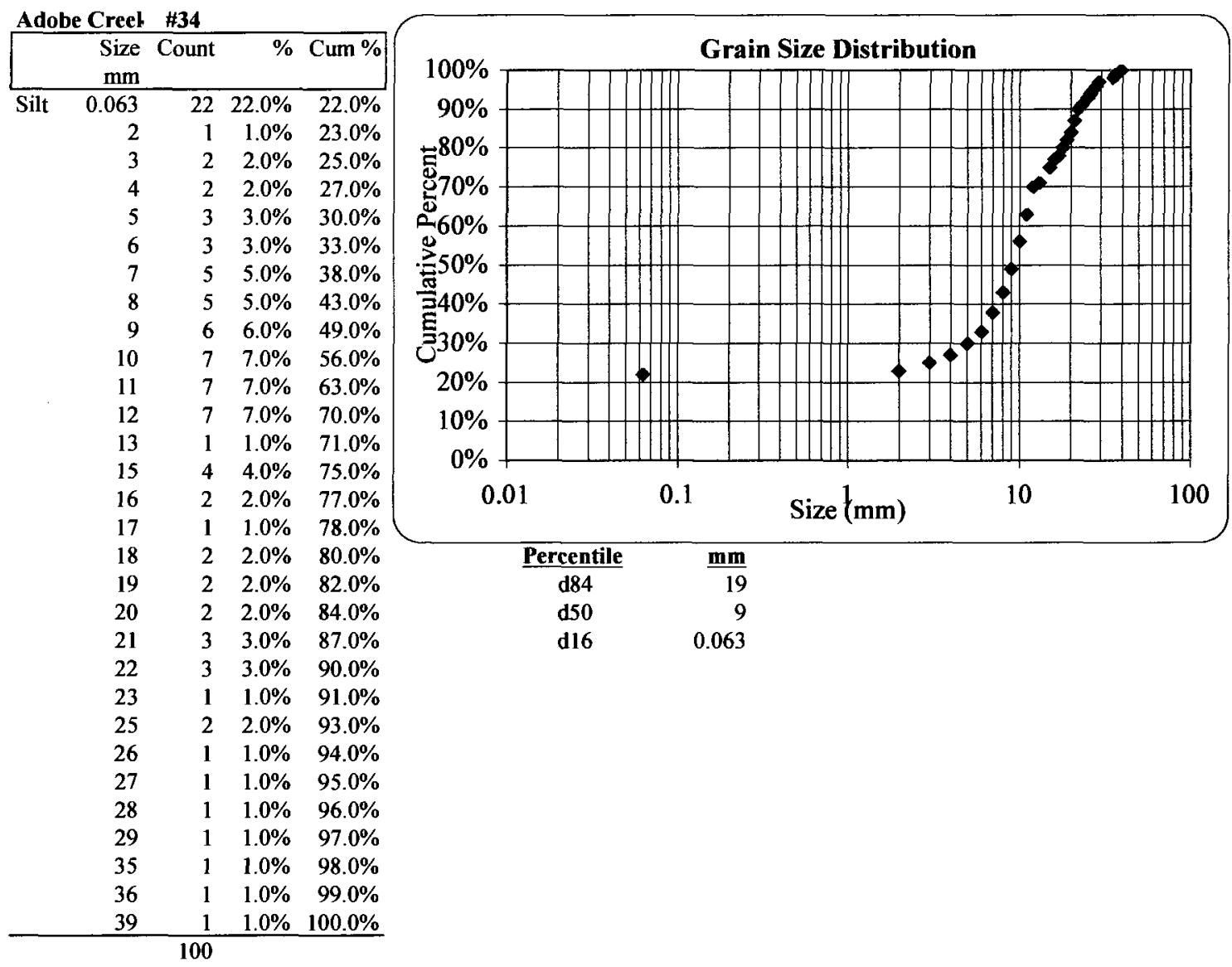




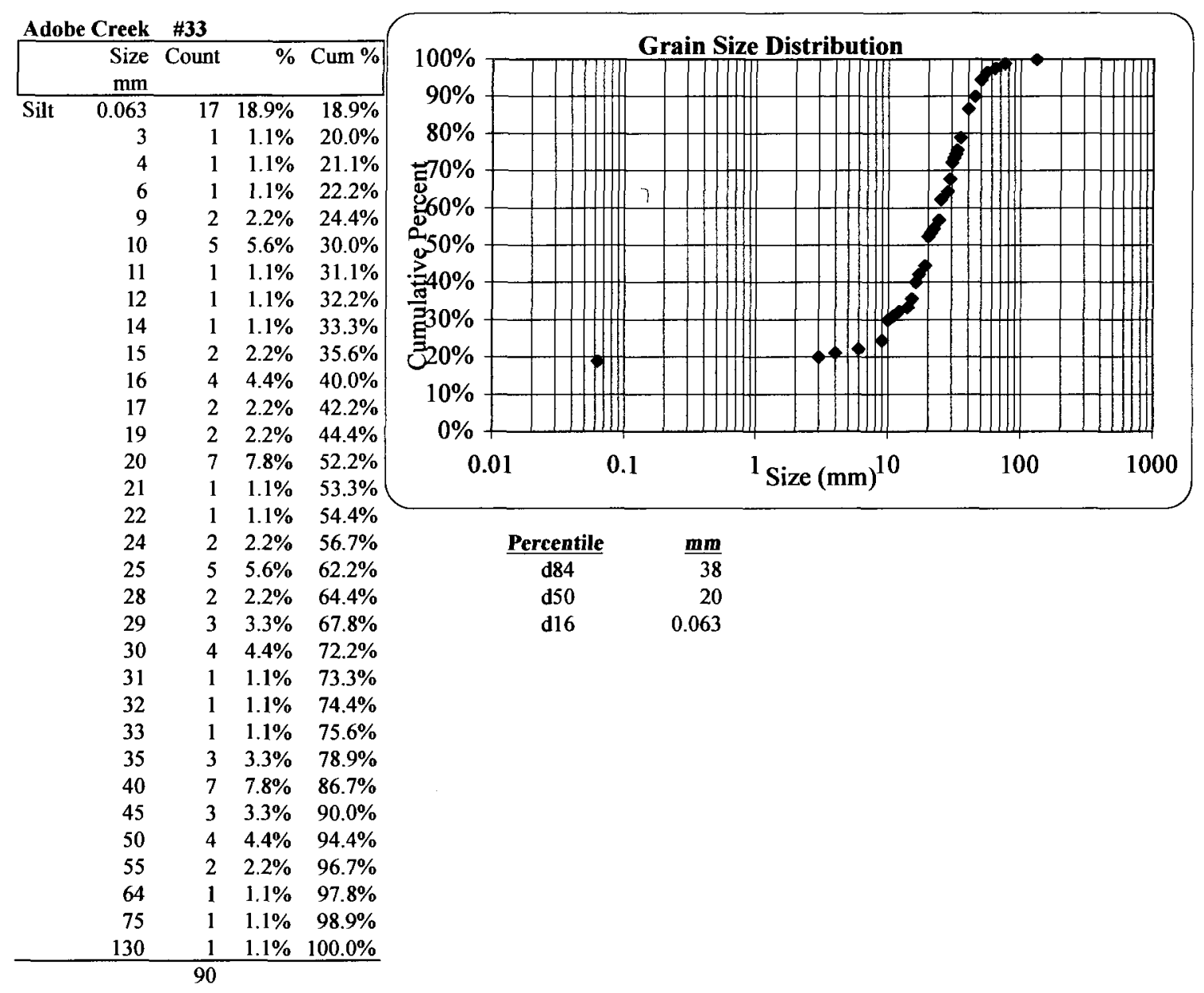




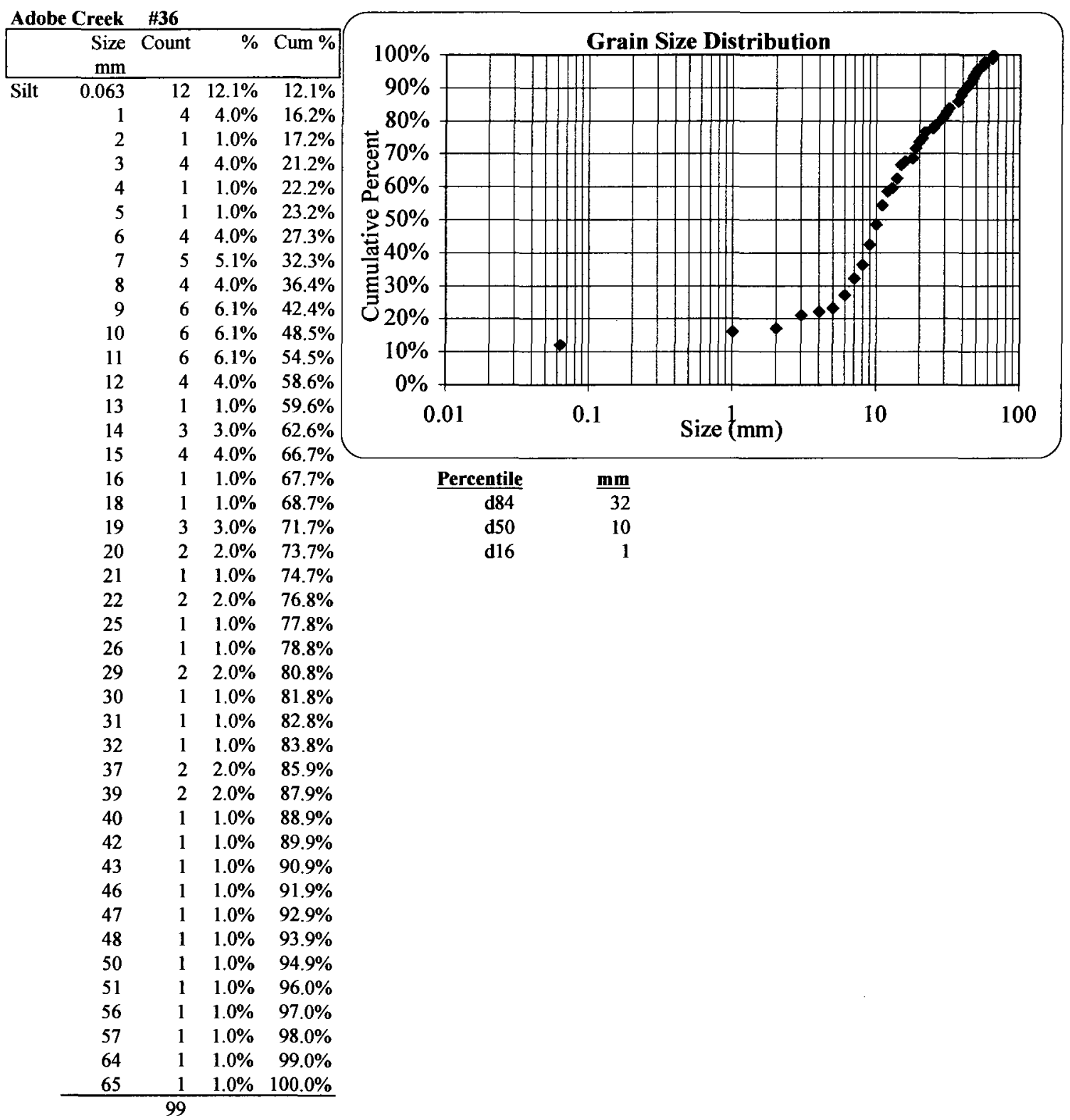




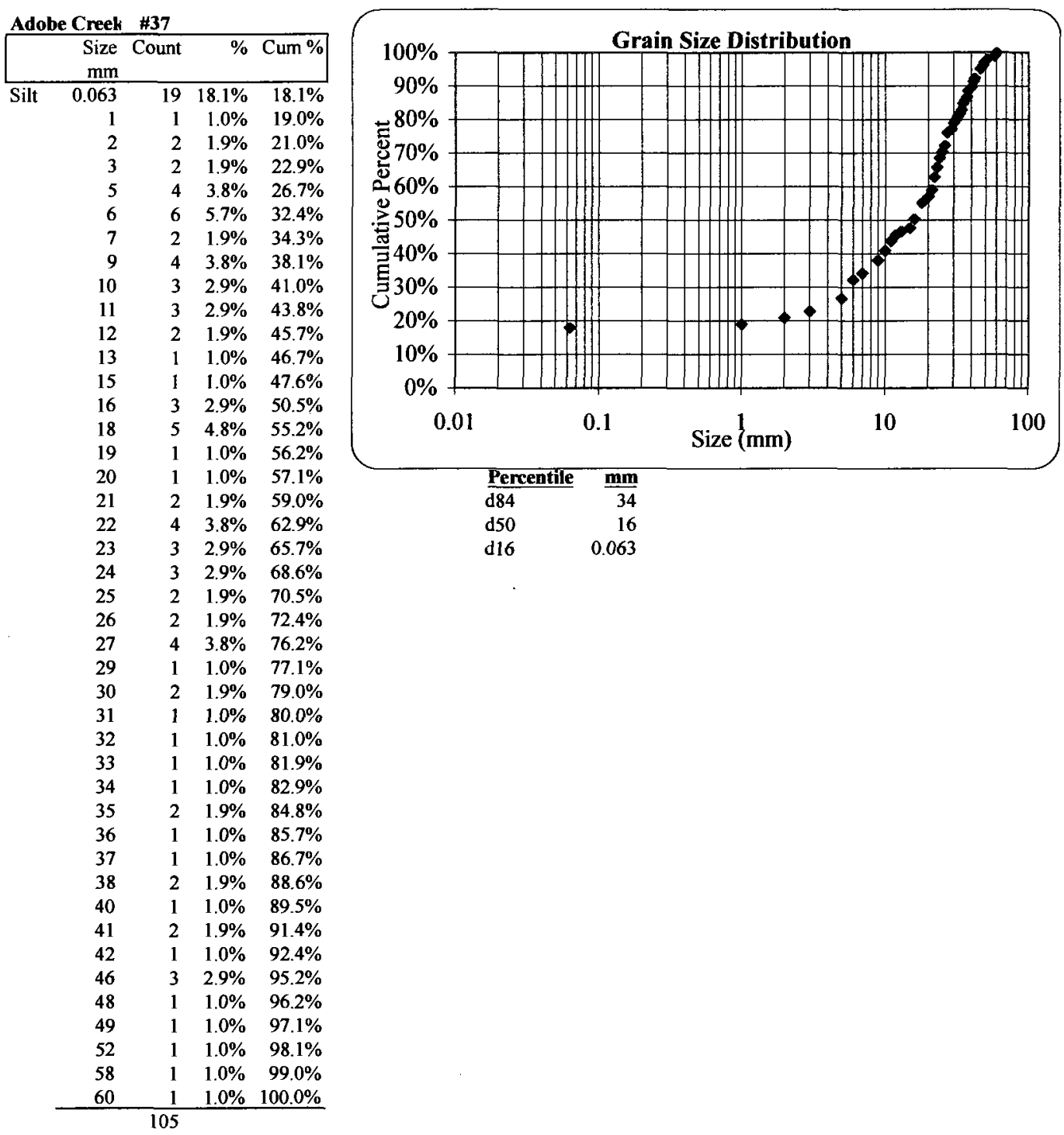




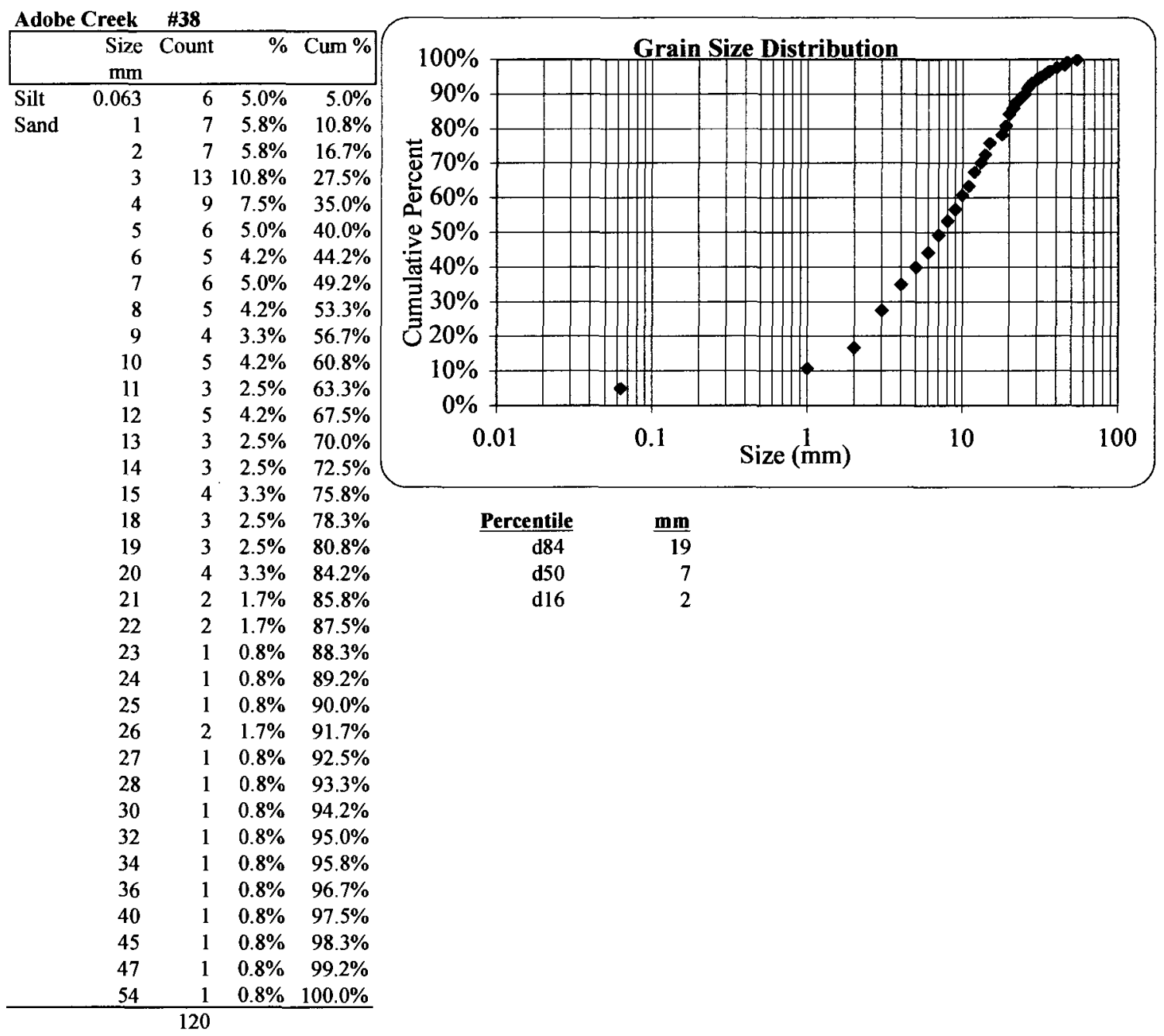




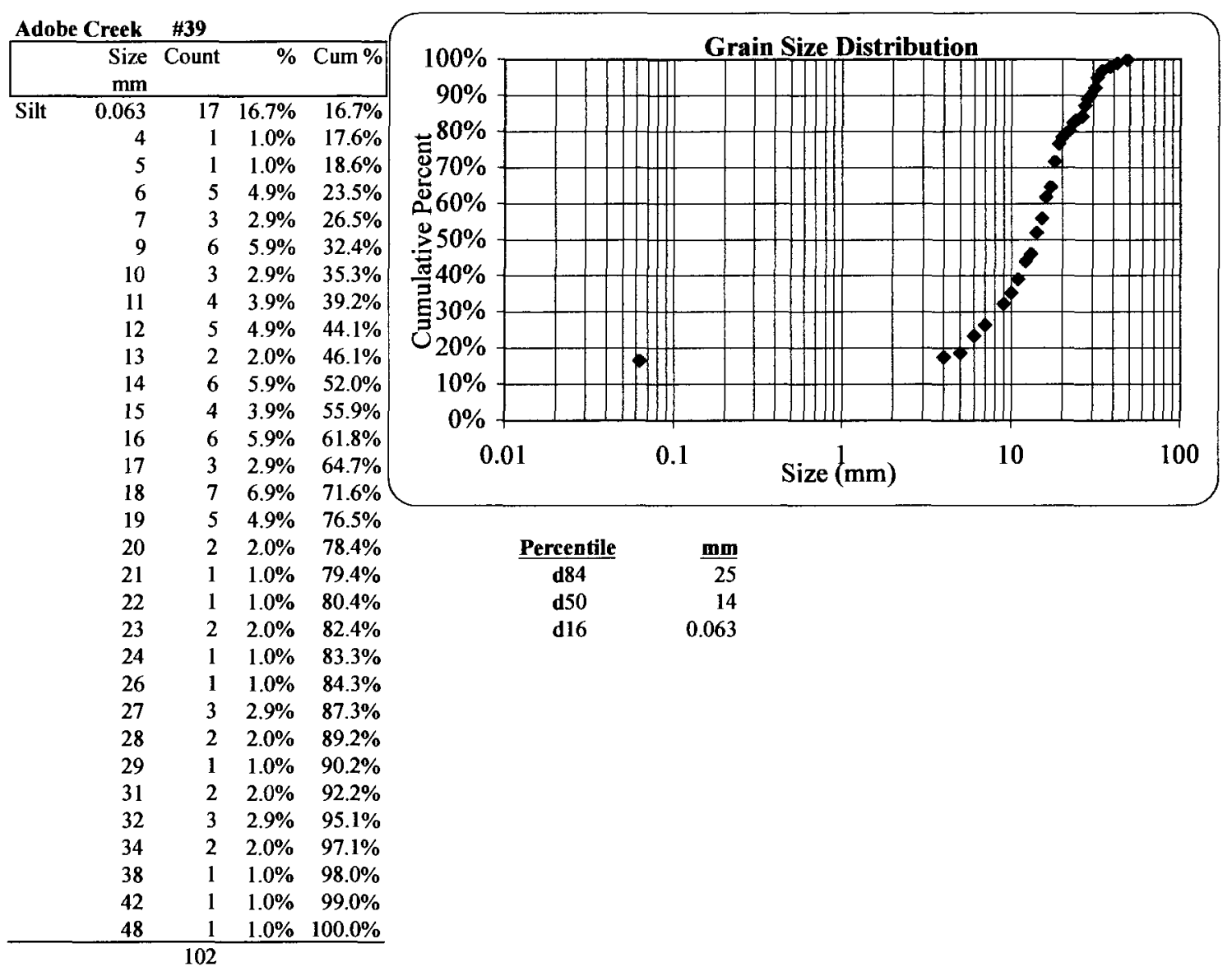




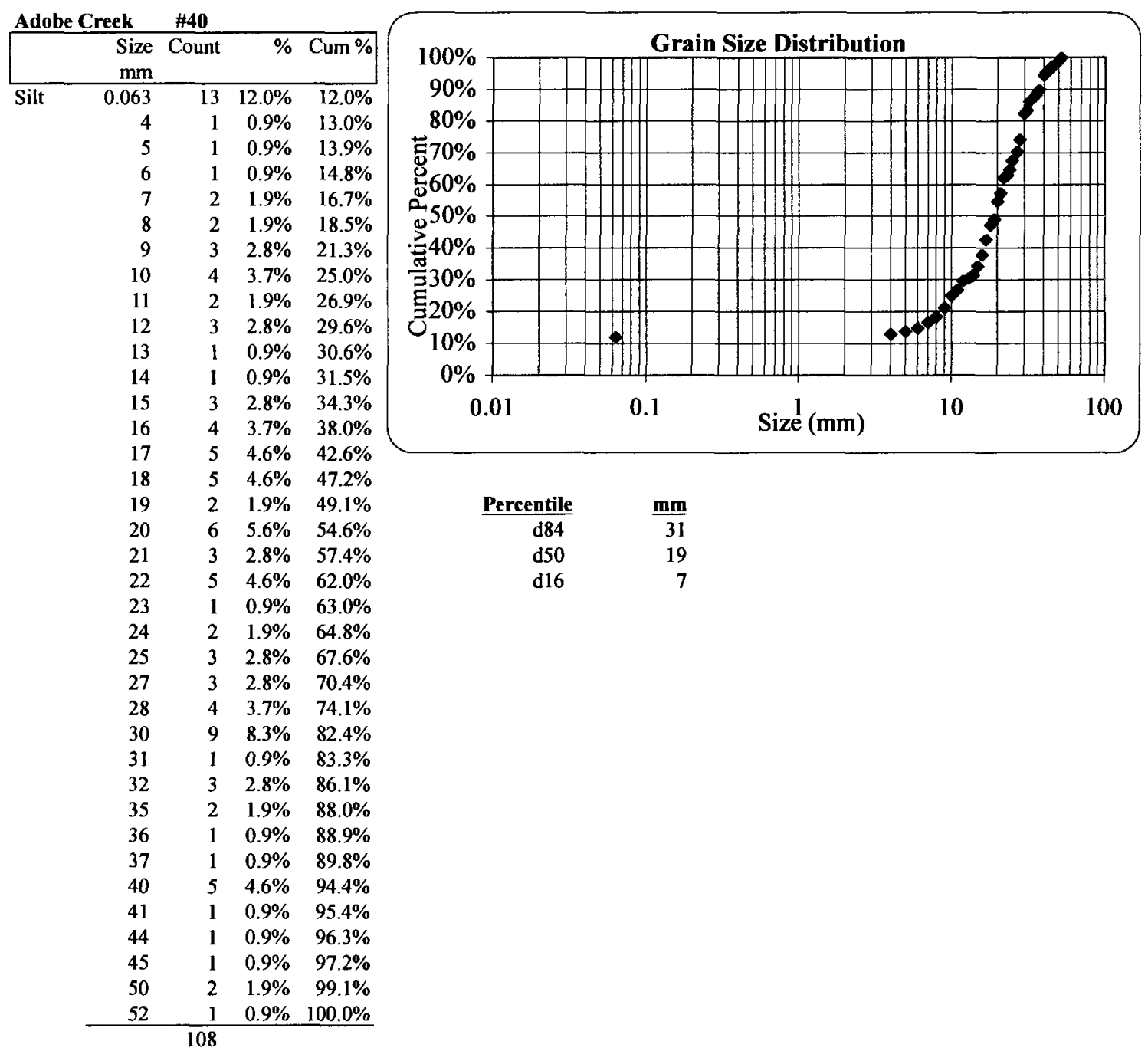




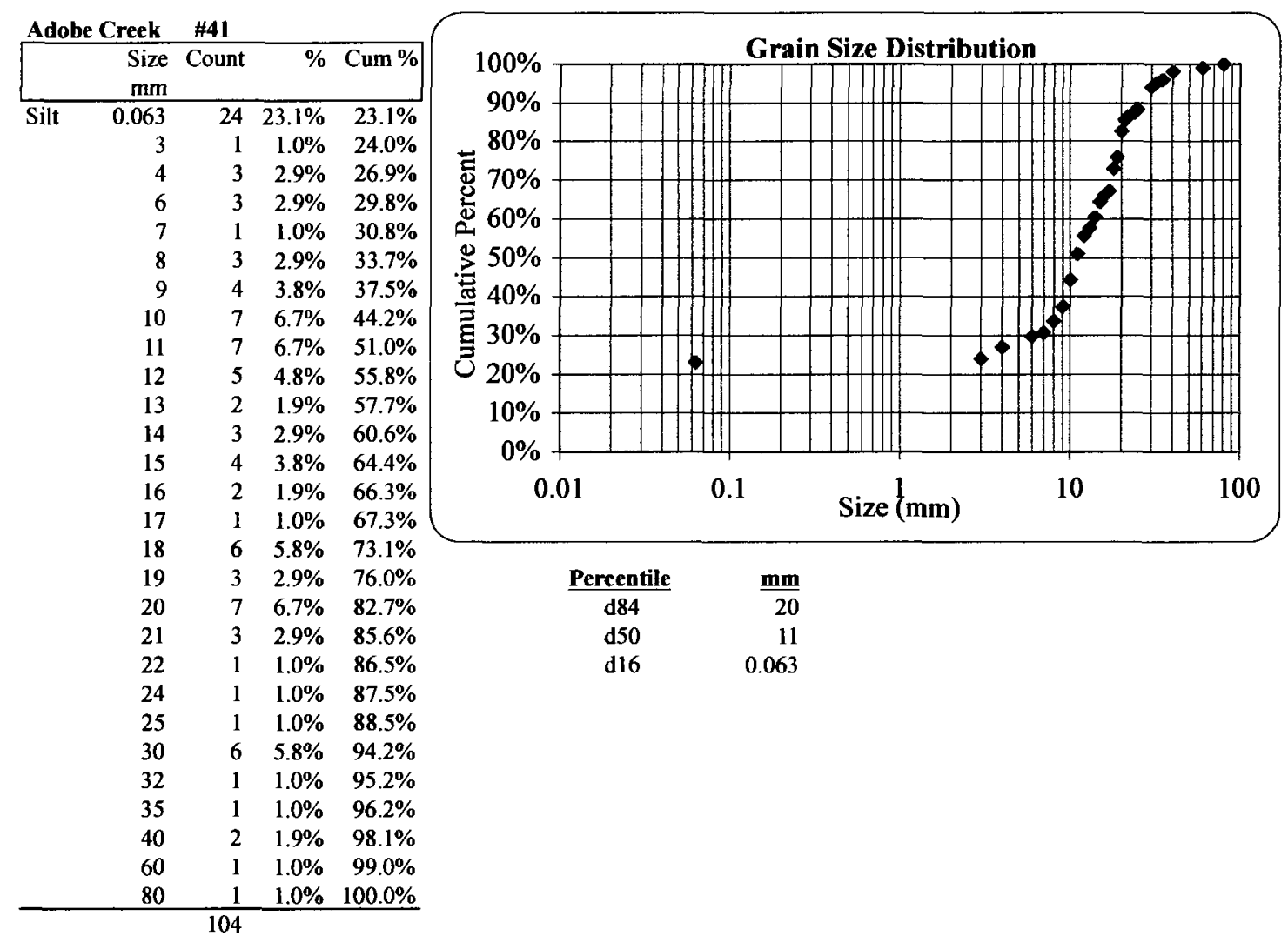




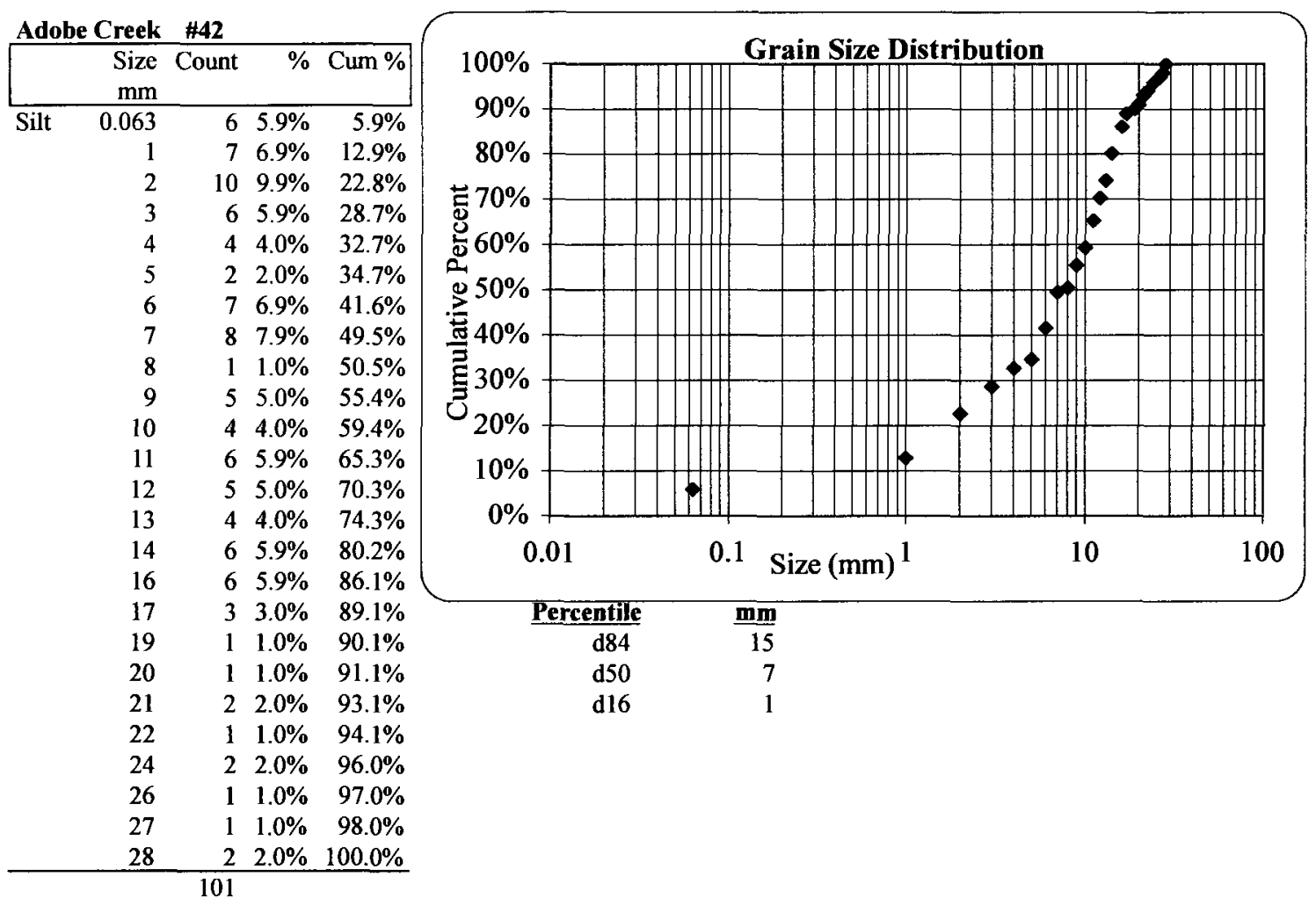




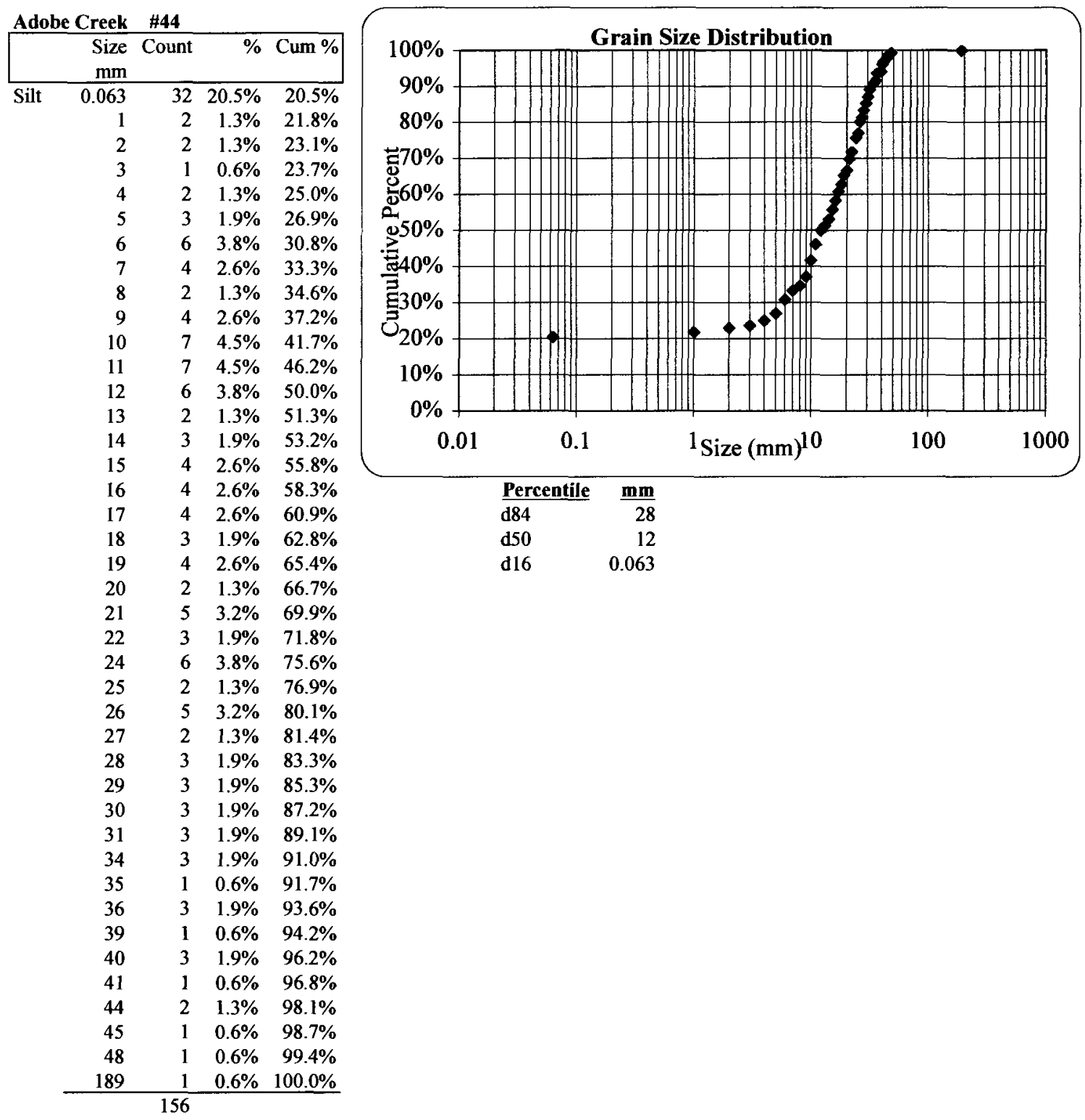




\begin{tabular}{|c|c|c|c|c|}
\hline \multicolumn{2}{|c|}{ Adobe Creek } & $\# 43$ & & \multirow[b]{2}{*}{ Cum \% } \\
\hline & $\begin{array}{l}\text { Size } \\
\mathrm{mm}\end{array}$ & Count & $\%$ & \\
\hline \multirow[t]{47}{*}{ Silt } & 0.063 & 19 & $13.7 \%$ & $13.7 \%$ \\
\hline & I & 7 & $5.0 \%$ & $18.7 \%$ \\
\hline & 3 & 1 & $0.7 \%$ & $19.4 \%$ \\
\hline & 4 & 1 & $0.7 \%$ & $20.1 \%$ \\
\hline & 5 & 1 & $0.7 \%$ & $20.9 \%$ \\
\hline & 6 & 5 & $3.6 \%$ & $24.5 \%$ \\
\hline & 7 & 2 & $1.4 \%$ & $25.9 \%$ \\
\hline & 8 & 2 & $1.4 \%$ & $27.3 \%$ \\
\hline & 9 & 4 & $2.9 \%$ & $30.2 \%$ \\
\hline & 10 & 6 & $4.3 \%$ & $34.5 \%$ \\
\hline & 11 & 7 & $5.0 \%$ & $39.6 \%$ \\
\hline & 12 & 2 & $1.4 \%$ & $41.0 \%$ \\
\hline & 13 & 1 & $0.7 \%$ & $41.7 \%$ \\
\hline & 14 & 2 & $1.4 \%$ & $43.2 \%$ \\
\hline & 15 & 6 & $4.3 \%$ & $47.5 \%$ \\
\hline & 16 & 5 & $3.6 \%$ & $51.1 \%$ \\
\hline & 17 & 5 & $3.6 \%$ & $54.7 \%$ \\
\hline & 18 & 5 & $3.6 \%$ & $58.3 \%$ \\
\hline & 19 & 2 & $1.4 \%$ & $59.7 \%$ \\
\hline & 20 & 8 & $5.8 \%$ & $65.5 \%$ \\
\hline & 21 & 2 & $1.4 \%$ & $66.9 \%$ \\
\hline & 22 & 2 & $1.4 \%$ & $68.3 \%$ \\
\hline & 23 & 1 & $0.7 \%$ & $69.1 \%$ \\
\hline & 24 & 1 & $0.7 \%$ & $69.8 \%$ \\
\hline & 25 & 4 & $2.9 \%$ & $72.7 \%$ \\
\hline & 26 & 3 & $2.2 \%$ & $74.8 \%$ \\
\hline & 27 & 2 & $1.4 \%$ & $76.3 \%$ \\
\hline & 28 & 1 & $0.7 \%$ & $77.0 \%$ \\
\hline & 29 & 2 & $1.4 \%$ & $78.4 \%$ \\
\hline & 30 & 6 & $4.3 \%$ & $82.7 \%$ \\
\hline & 31 & ] & $0.7 \%$ & $83.5 \%$ \\
\hline & 32 & 1 & $0.7 \%$ & $84.2 \%$ \\
\hline & 34 & 1 & $0.7 \%$ & $84.9 \%$ \\
\hline & 35 & 4 & $2.9 \%$ & $87.8 \%$ \\
\hline & 36 & 2 & $1.4 \%$ & $89.2 \%$ \\
\hline & 37 & 1 & $0.7 \%$ & $89.9 \%$ \\
\hline & 38 & 3 & $2.2 \%$ & $92.1 \%$ \\
\hline & 40 & 1 & $0.7 \%$ & $92.8 \%$ \\
\hline & 44 & 1 & $0.7 \%$ & $93.5 \%$ \\
\hline & 45 & 2 & $1.4 \%$ & $95.0 \%$ \\
\hline & 48 & 1 & $0.7 \%$ & $95.7 \%$ \\
\hline & 50 & 1 & $0.7 \%$ & $96.4 \%$ \\
\hline & 51 & 1 & $0.7 \%$ & $97.1 \%$ \\
\hline & 52 & 1 & $0.7 \%$ & $97.8 \%$ \\
\hline & 54 & 1 & $0.7 \%$ & $98.6 \%$ \\
\hline & 66 & 1 & $0.7 \%$ & $99.3 \%$ \\
\hline & 98 & 1 & $0.7 \%$ & $100.0 \%$ \\
\hline & & 139 & & \\
\hline
\end{tabular}

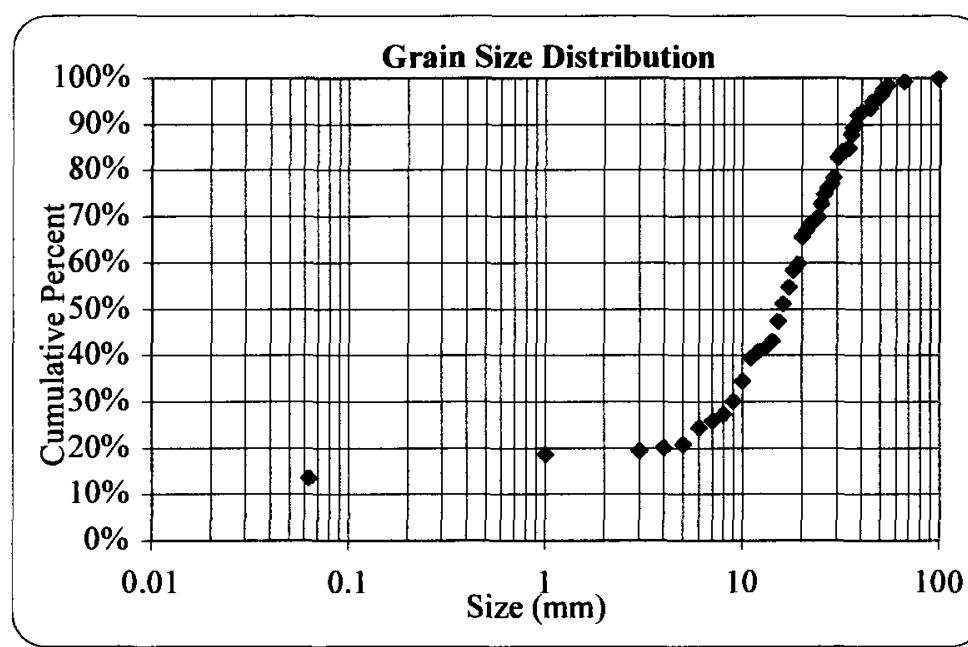

$\begin{array}{cr}\text { Percentile } & \frac{\mathrm{mm}}{31} \\ \text { d84 } & 16 \\ \text { d50 } & 16 \\ \text { d16 } & 0.497\end{array}$




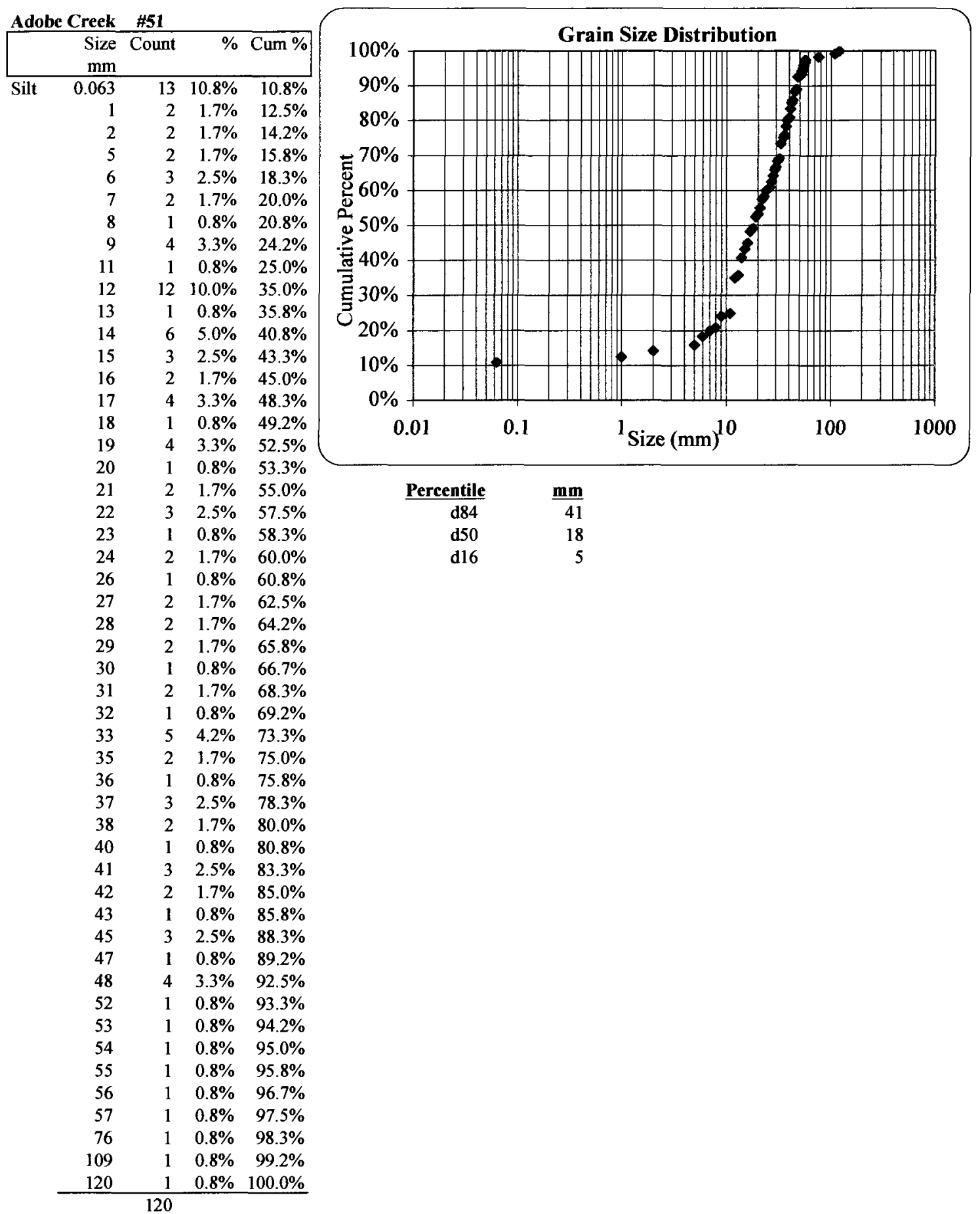




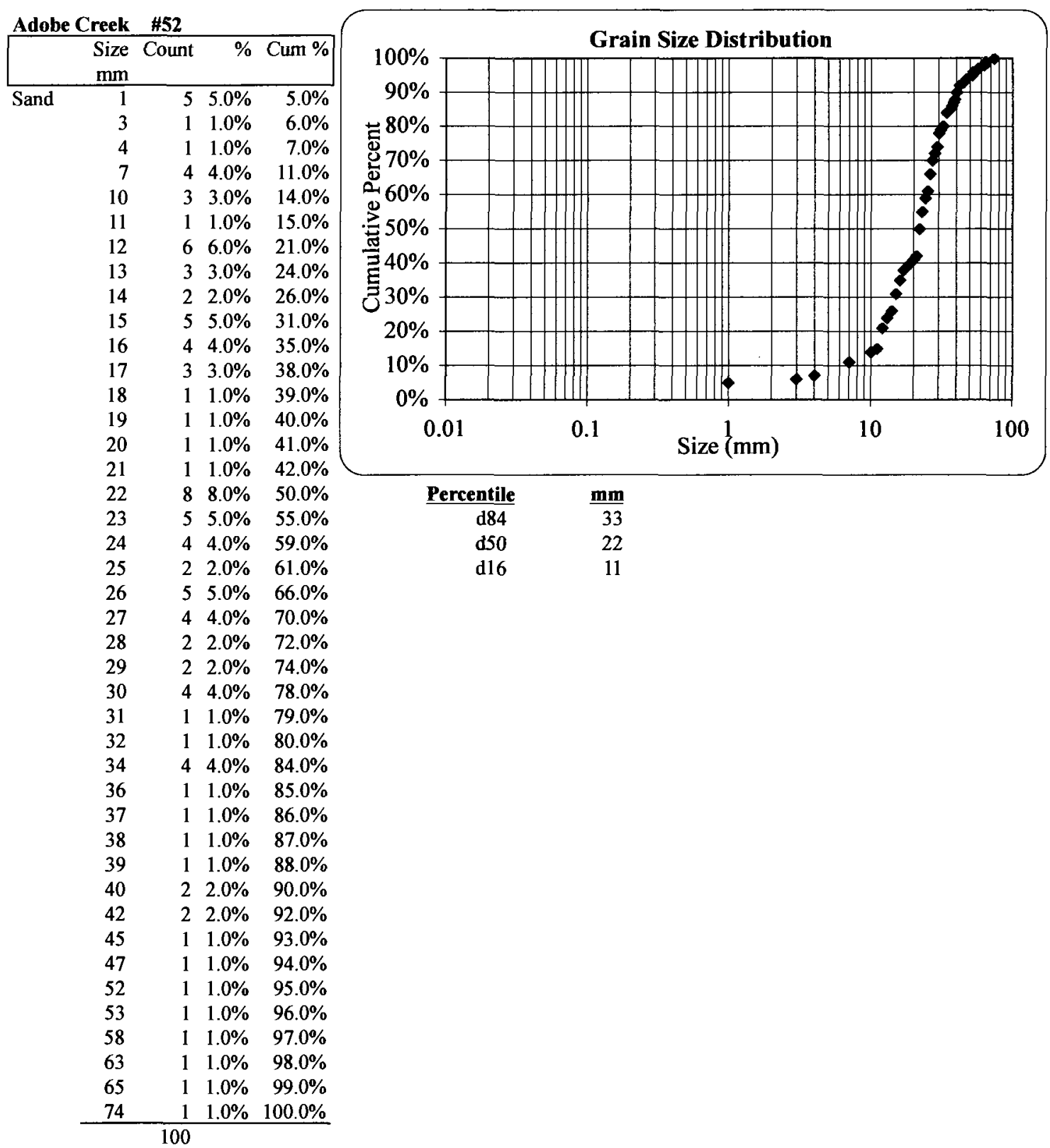




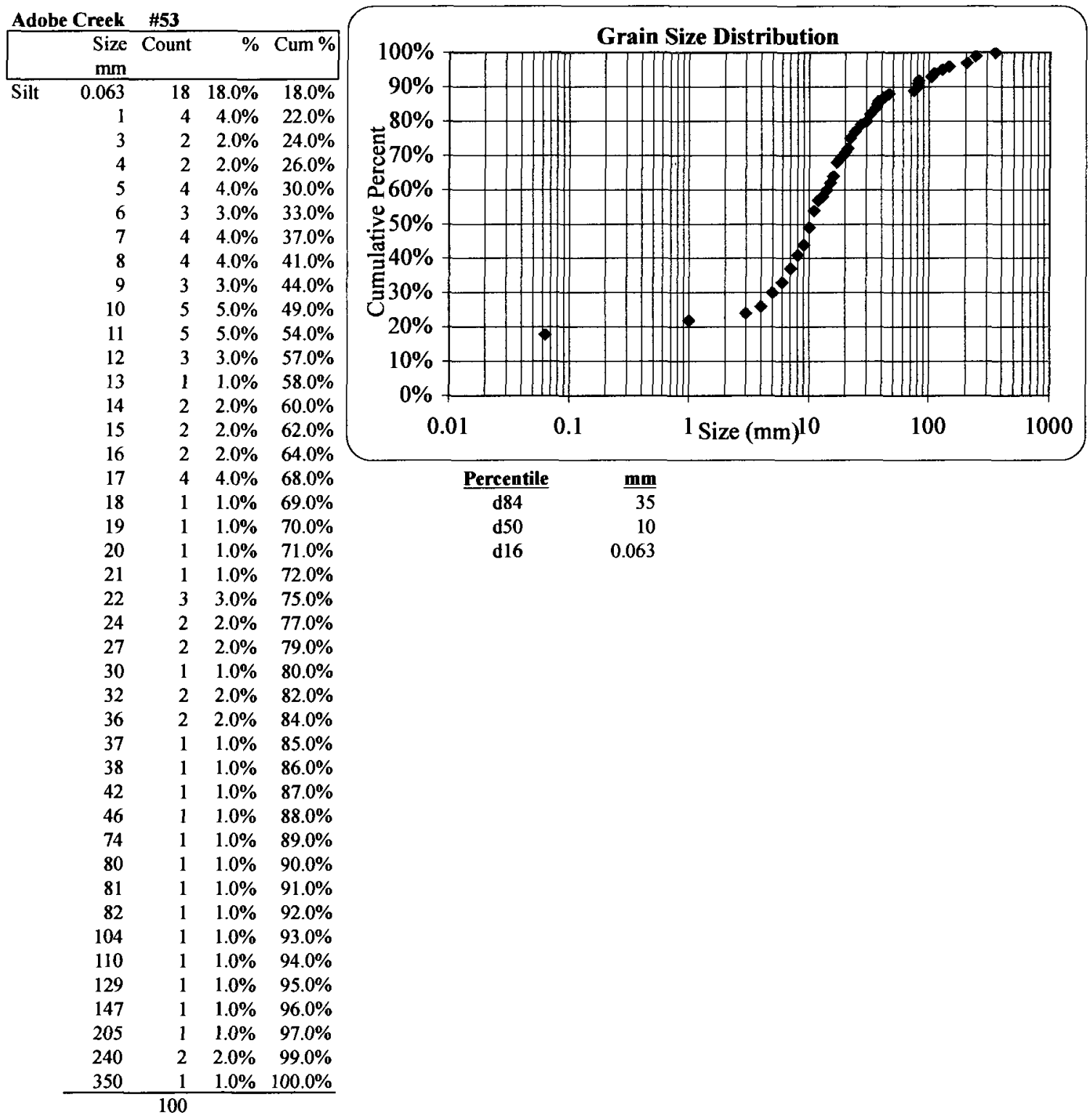


Adobe Creek \#54

\begin{tabular}{|c|c|c|c|c|}
\hline & $\begin{array}{c}\text { Size } \\
\mathrm{mm}\end{array}$ & Count & $\%$ & Cum \% \\
\hline Clay & 0.01 & 4 & $3.7 \%$ & $3.7 \%$ \\
\hline \multirow[t]{16}{*}{ Silt } & 0.063 & 8 & $7.5 \%$ & $11.2 \%$ \\
\hline & 1 & 6 & $5.6 \%$ & $16.8 \%$ \\
\hline & 3 & 2 & $1.9 \%$ & $18.7 \%$ \\
\hline & 4 & 3 & $2.8 \%$ & $21.5 \%$ \\
\hline & 5 & 2 & $1.9 \%$ & $23.4 \%$ \\
\hline & 6 & 2 & $1.9 \%$ & $25.2 \%$ \\
\hline & 7 & 1 & $0.9 \%$ & $26.2 \%$ \\
\hline & 9 & 1 & $0.9 \%$ & $27.1 \%$ \\
\hline & 11 & 4 & $3.7 \%$ & $30.8 \%$ \\
\hline & 12 & 3 & $2.8 \%$ & $33.6 \%$ \\
\hline & 14 & 3 & $2.8 \%$ & $36.4 \%$ \\
\hline & 16 & 1 & $0.9 \%$ & $37.4 \%$ \\
\hline & 17 & 4 & $3.7 \%$ & $41.1 \%$ \\
\hline & 18 & 1 & $0.9 \%$ & $42.1 \%$ \\
\hline & 21 & 6 & $5.6 \%$ & $47.7 \%$ \\
\hline & 22 & 1 & $0.9 \%$ & $48.6 \%$ \\
\hline \multirow[t]{35}{*}{ - } & 25 & 1 & $0.9 \%$ & $49.5 \%$ \\
\hline & 27 & 1 & $0.9 \%$ & $50.5 \%$ \\
\hline & 30 & 1 & $0.9 \%$ & $51.4 \%$ \\
\hline & 32 & 2 & $1.9 \%$ & $53.3 \%$ \\
\hline & 36 & 1 & $0.9 \%$ & $54.2 \%$ \\
\hline & 37 & 3 & $2.8 \%$ & $57.0 \%$ \\
\hline & 42 & 2 & $1.9 \%$ & $58.9 \%$ \\
\hline & 44 & 1 & $0.9 \%$ & $59.8 \%$ \\
\hline & 45 & 2 & $1.9 \%$ & $61.7 \%$ \\
\hline & 47 & 2 & $1.9 \%$ & $63.6 \%$ \\
\hline & 52 & 1 & $0.9 \%$ & $64.5 \%$ \\
\hline & 54 & 1 & $0.9 \%$ & $65.4 \%$ \\
\hline & 58 & 1 & $0.9 \%$ & $66.4 \%$ \\
\hline & 62 & 1 & $0.9 \%$ & $67.3 \%$ \\
\hline & 63 & 1 & $0.9 \%$ & $68.2 \%$ \\
\hline & 64 & 1 & $0.9 \%$ & $69.2 \%$ \\
\hline & 72 & 1 & $0.9 \%$ & $70.1 \%$ \\
\hline & 74 & 1 & $0.9 \%$ & $71.0 \%$ \\
\hline & 76 & 1 & $0.9 \%$ & $72.0 \%$ \\
\hline & 79 & 1 & $0.9 \%$ & $72.9 \%$ \\
\hline & 82 & 1 & $0.9 \%$ & $73.8 \%$ \\
\hline & 86 & 2 & $1.9 \%$ & $75.7 \%$ \\
\hline & 92 & 1 & $0.9 \%$ & $76.6 \%$ \\
\hline & 94 & 1 & $0.9 \%$ & $77.6 \%$ \\
\hline & 97 & 1 & $0.9 \%$ & $78.5 \%$ \\
\hline & 114 & 1 & $0.9 \%$ & $79.4 \%$ \\
\hline & 123 & 1 & $0.9 \%$ & $80.4 \%$ \\
\hline & 128 & 1 & $0.9 \%$ & $81.3 \%$ \\
\hline & 132 & 1 & $0.9 \%$ & $82.2 \%$ \\
\hline & 140 & 1 & $0.9 \%$ & $83.2 \%$ \\
\hline & 145 & 1 & $0.9 \%$ & $84.1 \%$ \\
\hline & 176 & 1 & $0.9 \%$ & $85.0 \%$ \\
\hline & 185 & 1 & $0.9 \%$ & $86.0 \%$ \\
\hline & 195 & 1 & $0.9 \%$ & $86.9 \%$ \\
\hline & 500 & 14 & $13.1 \%$ & $100.0 \%$ \\
\hline
\end{tabular}

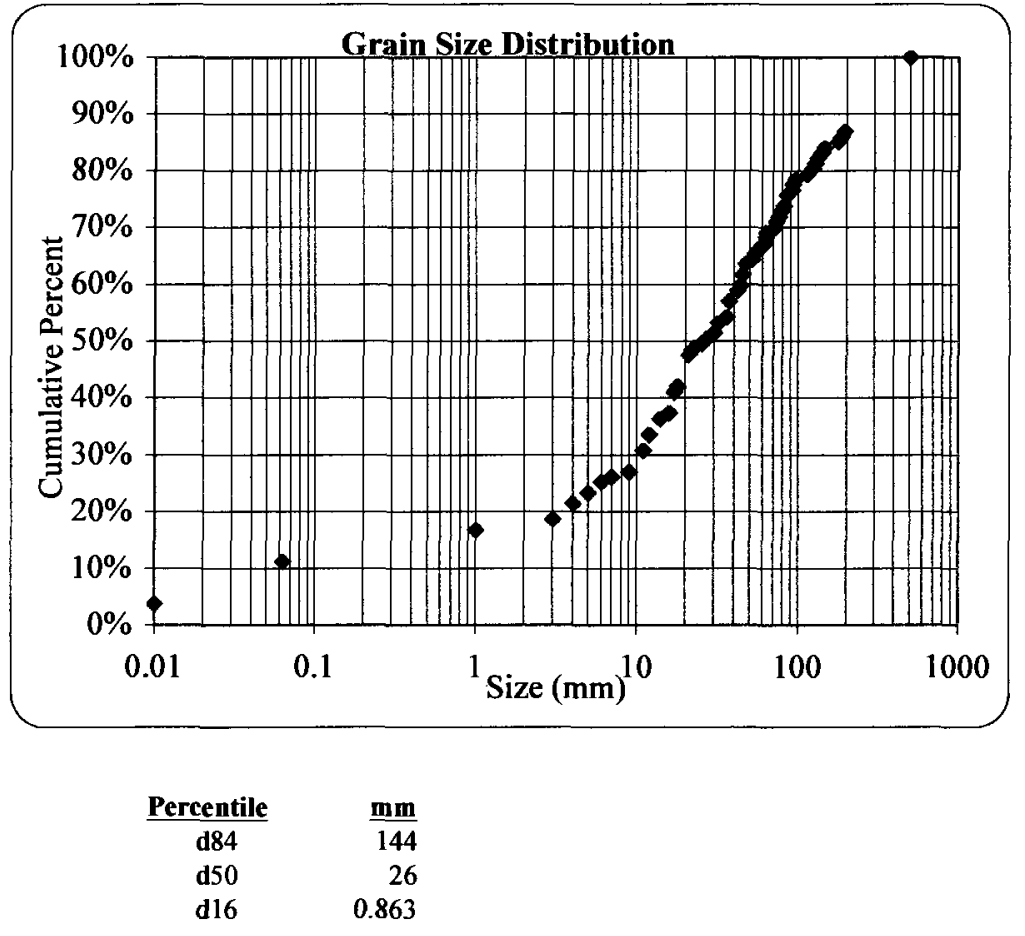




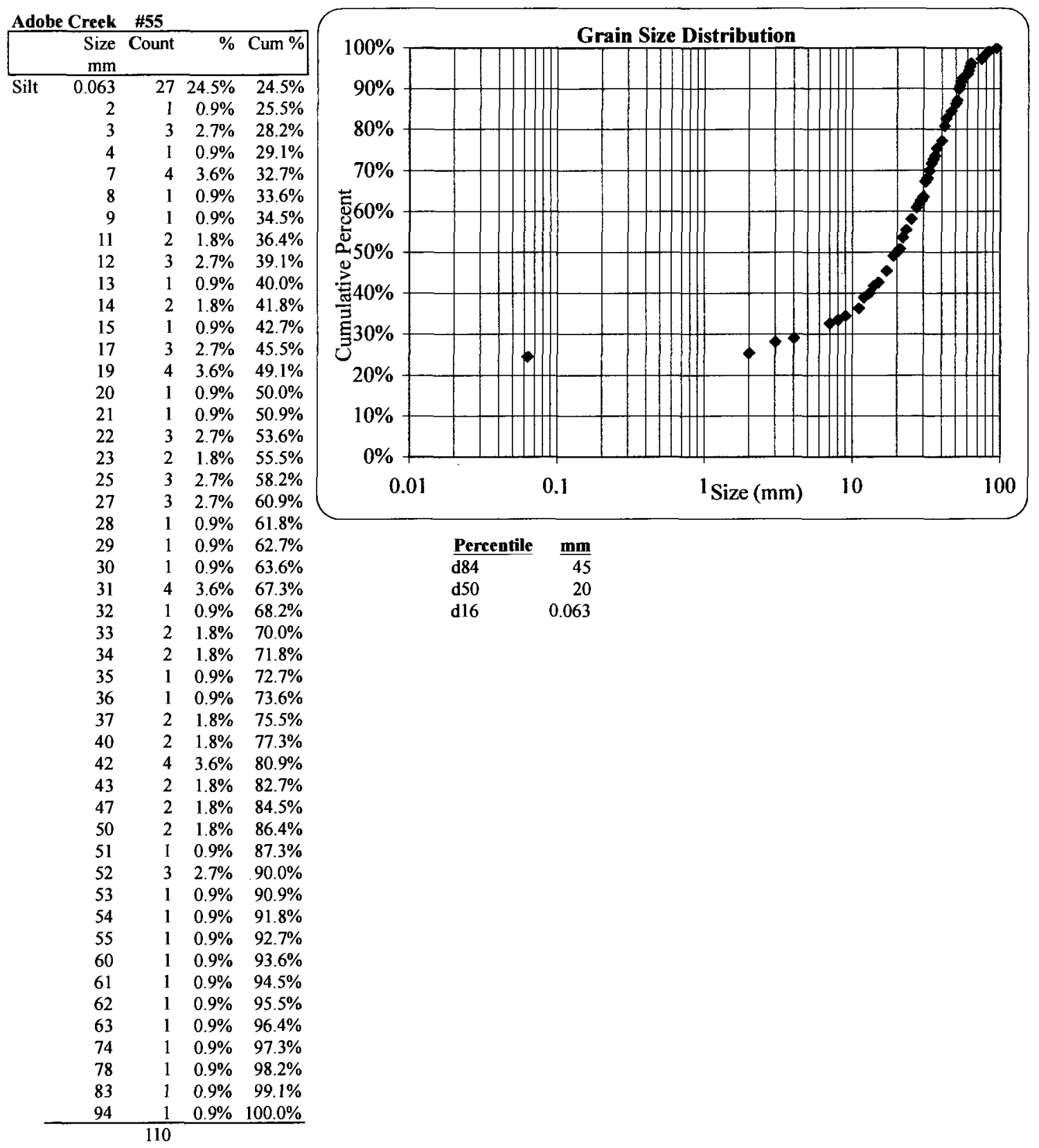




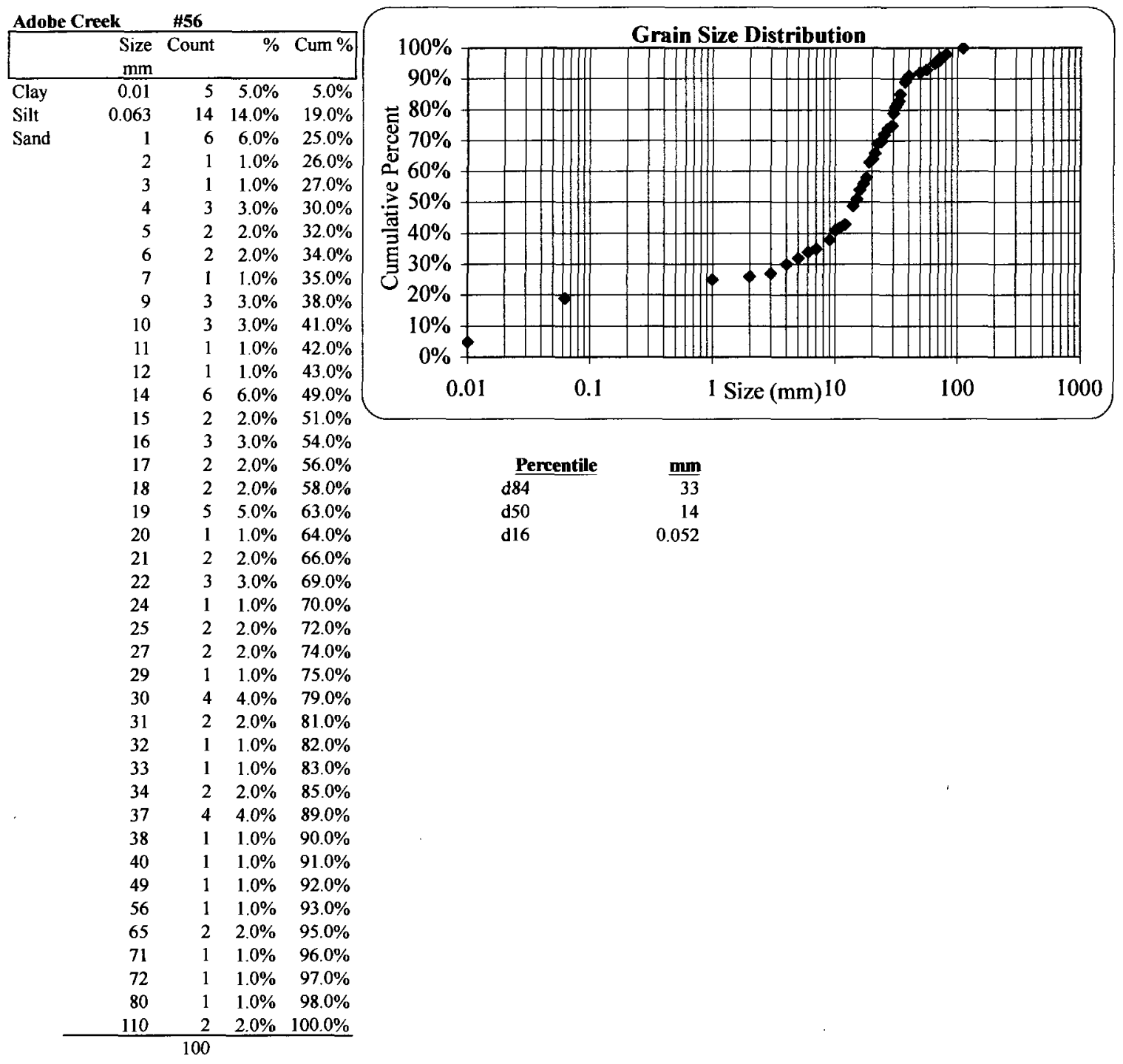




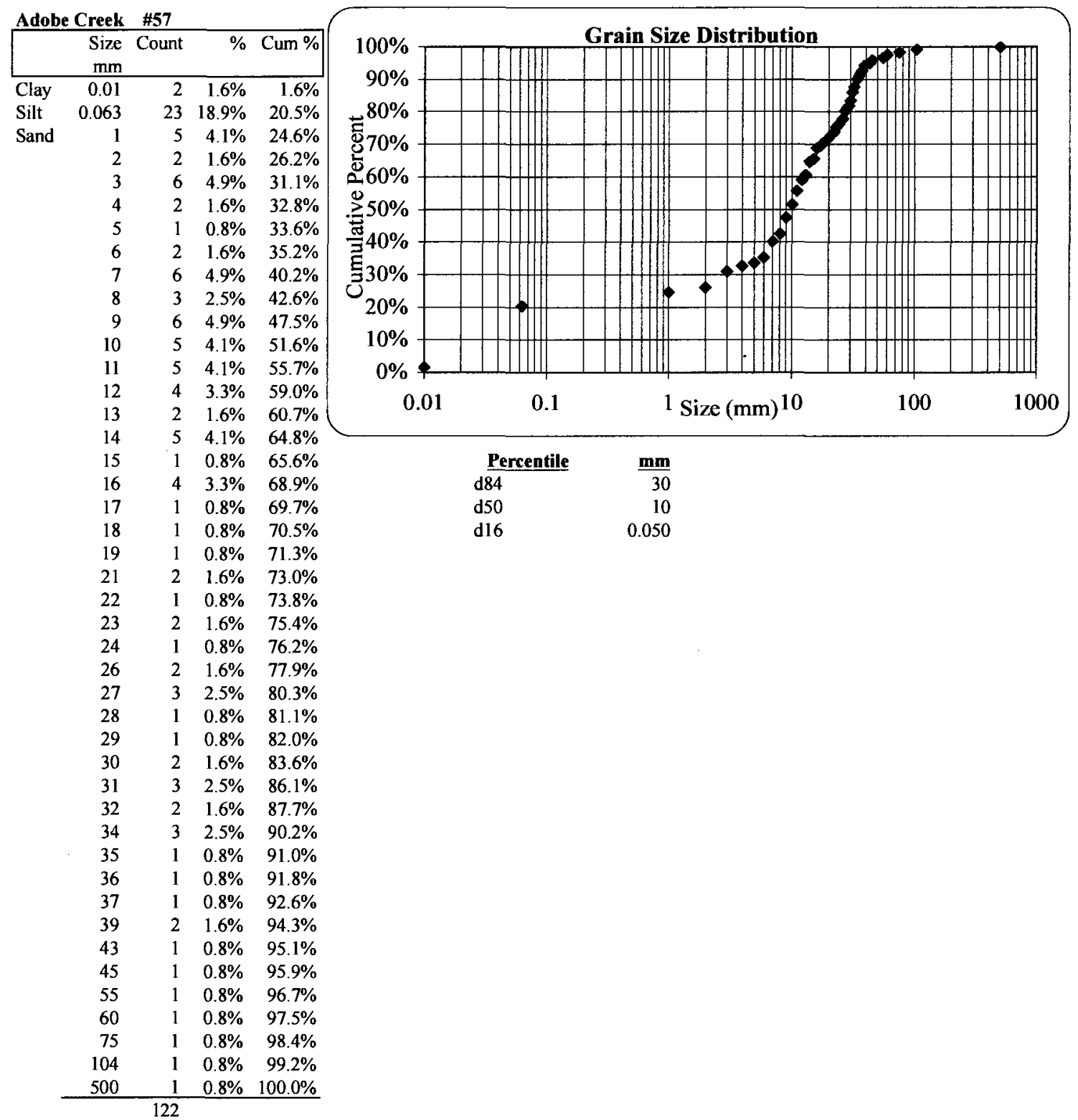

